Florida International University FIU Digital Commons

3-24-2014

\title{
OPEC and the International System: A Political History of Decisions and Behavior
}

Reza Sanati

Florida International University, rsanati002@fiu.edu

DOI: $10.25148 /$ etd.FI14040875

Follow this and additional works at: https://digitalcommons.fiu.edu/etd

Part of the International Relations Commons

\section{Recommended Citation}

Sanati, Reza, "OPEC and the International System: A Political History of Decisions and Behavior" (2014). FIU Electronic Theses and Dissertations. 1149.

https://digitalcommons.fiu.edu/etd/1149

This work is brought to you for free and open access by the University Graduate School at FIU Digital Commons. It has been accepted for inclusion in FIU Electronic Theses and Dissertations by an authorized administrator of FIU Digital Commons. For more information, please contact dcc@fiu.edu. 


\section{FLORIDA INTERNATIONAL UNIVERSITY \\ Miami, Florida}

\section{OPEC AND THE INTERNATIONAL SYSTEM: A POLITICAL HISTORY OF DECISIONS AND BEHAVIOR}

A dissertation submitted in partial fulfillment of

the requirements for the degree of

DOCTOR OF PHILOSOPHY

in

INTERNATIONAL RELATIONS

by

Reza Sanati

2014 
To: Dean Kenneth G. Furton

College of Arts and Sciences

This dissertation, written by Reza Sanati, and entitled OPEC and the International System: A Political History of Decisions and Behavior, having been approved in respect to style and intellectual content, is referred to you for judgment.

We have read this dissertation and recommend that it be approved.

Thomas Breslin

Mira Wilkins

Ronald Cox

Mohiaddin Mesbahi, Major Professor

Date of Defense: March 24, 2014

The dissertation of Reza Sanati is approved.

Dean Kenneth G. Furton

College of Arts and Sciences

Dean Lakshmi N. Reddi

University Graduate School

Florida International University, 2014 
(C) Copyright 2014 by Reza Sanati

All rights reserved. 


\title{
ABSTRACT OF THE DISSERTATION \\ OPEC AND THE INTERNATIONAL SYSTEM \\ A POLITICAL HISTORY OF DECISIONS AND BEHAVIOR
}

\author{
by \\ Reza Sanati \\ Florida International University, 2014 \\ Miami, Florida

\section{Professor Mohiaddin Mesbahi, Major Professor}

The conventional understanding behind how the Organization of Petroleum Exporting Countries (OPEC) has formulated its decisions and subsequently behaved in the international system has consistently centered on the role of market forces. Either proactively or reactively, it has been assumed that OPEC's actions were merely engaging and responding to the supply and demand dynamics in the global economy. Though space was always given to the political considerations of certain OPEC Member States, and how that impacts the behavior of the Organization, inquiry into OPEC decision-making and behavior has generally centered on economic considerations, with politics playing an intermittent supporting role.

This work challenges the assumptions behind the conventional narrative of OPEC's behavior in the international system. By utilizing a historically-based process tracing method, relying heavily on archival data from OPEC's headquarters and declassified American national security documents from the late 1940s to the present, a more sophisticated model of decision-making and behavior is developed. Accordingly, OPEC's decisions and behavior are more accurately a product of four inter-related 
determinants: the role of market forces, the influence of outside actors (usually great powers) upon the Organization, interstate relations and politics among Member States, and the pressure of the internal state dynamics within OPEC Member States. It is at the intersection of these four variables where OPEC's behavior is more readily understood. Thus, with a sophisticated understanding of the interplay of these determinants, OPEC's decision-making process and behavior can be more accurately understood and possibly forecasted to a limited degree. 


\section{TABLE OF CONTENTS}

CHAPTER PAGE

INTRODUCTION • UNDERSTANDING THE DETERMINANTS BEHIND OPEC'S

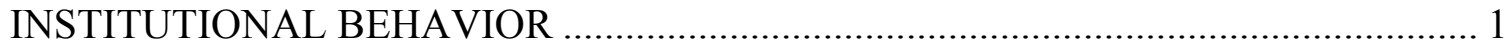

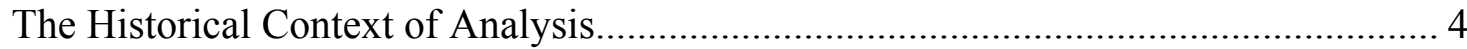

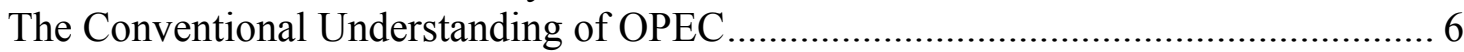

Cartel vs. Economically-based Intergovernmental organization .................................. 6

Why the Cartel and Economically-based Intergovernmental organization labels fall

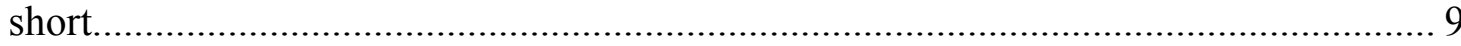

A New Framework of Analysis ............................................................................ 13

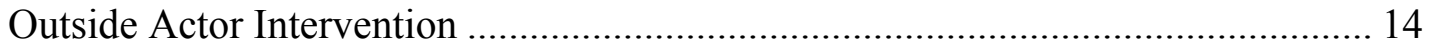

Interstate Member Relations within the Organization........................................... 16

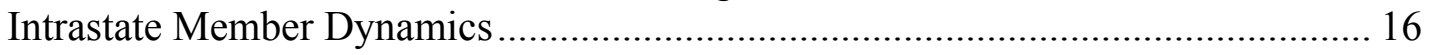

CHAPTER I • THE EMBRYONIC PHASE: THE RISE AND FALL OF THE

CONCESSIONARY SYSTEM \& THE BIRTH OF OPEC .......................................... 19

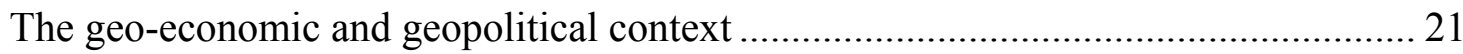

Creating the Home-IOC-Host triangle ..................................................................... 21

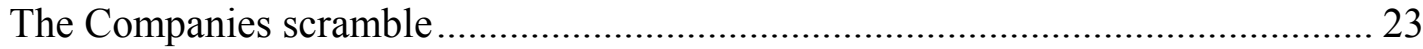

Expanding the Concession System in the Middle East............................................ 28

The Seeds of Nationalization and the beginnings of the domino cascade.................... 33

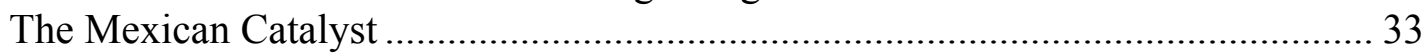

The spread of the 50/50 arrangement....................................................................... 40

Changes in the Imperial roles in the Middle East and 50/50 challenged in Iran ...... 43

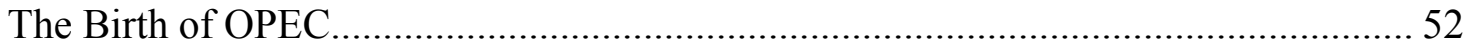

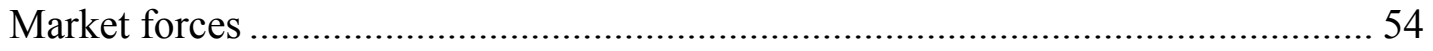

The immediate pre-OPEC global oil dynamics ....................................................... 54

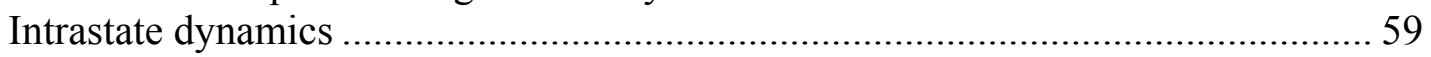

The Internal Picture of the main proto-OPEC member states ……………............... 59

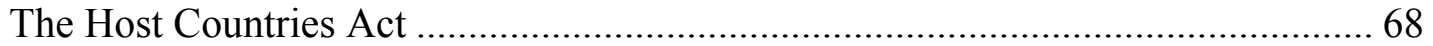

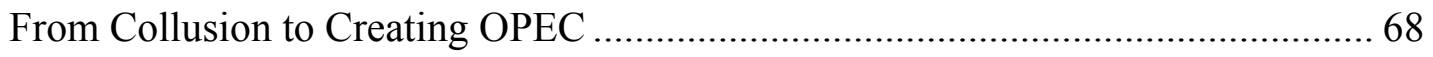

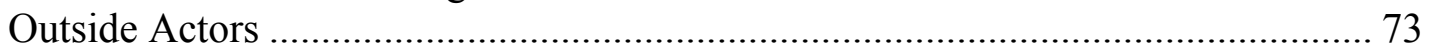

The US policy of Conscious Indifference: the fall of the Home-IOC-Host Nexus .. 73

CHAPTER II • THE INFANCY PHASE: THE INSTITUTIONALIZATION OF

OPEC AND THE STRUGGLE FOR COLLECTIVE ACTION, 1961-1969 ………....... 82

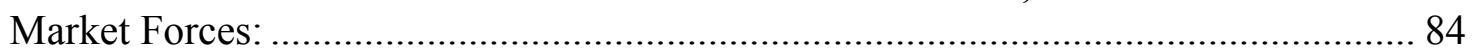

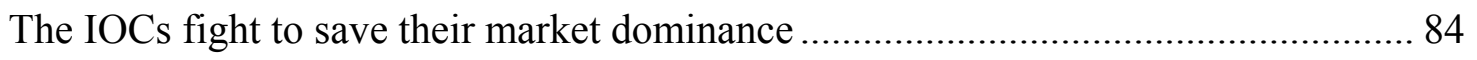

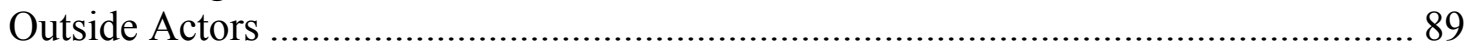

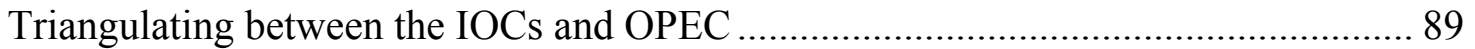

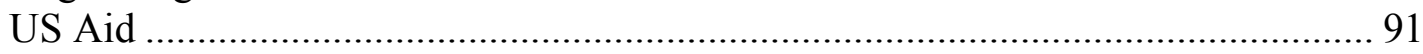

The beginning of Indirect American influence within OPEC .................................... 91

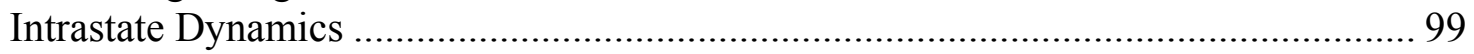

The Domestic Political Landscape........................................................................ 99

The Beginnings of the National Oil Companies ..................................................... 106 


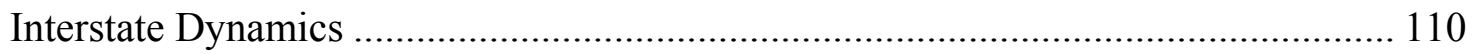

Organizational Enlargement and Negotiation......................................................... 110

Building the Organs of OPEC while Individual Negotiations begin ....................... 114

Collective Negotiations with the IOCs ............................................................... 127

CHAPTER III • THE ASCENDANCY PHASE: THE SHIFT OF POWER TO THE PRODUCERS, ORGANIZATIONAL ACTION, AND THE POLITICIZATION OF

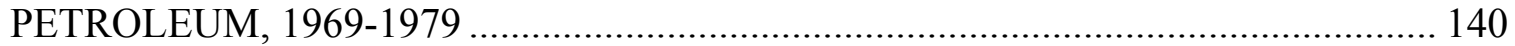

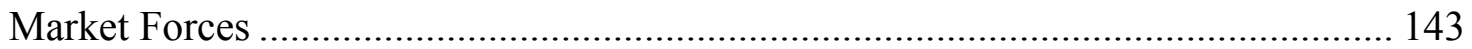

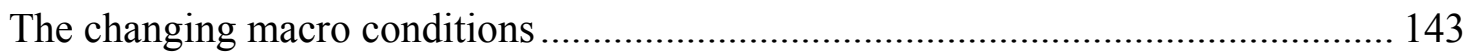

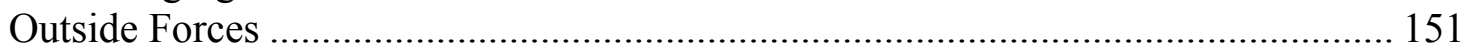

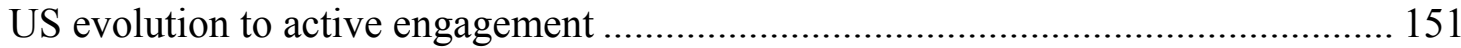

British Middle Eastern Withdrawal and US Twin Pillar Policy .............................. 152

US pushed into role as de-facto intermediary in OPEC-Companies negotiations.. 155

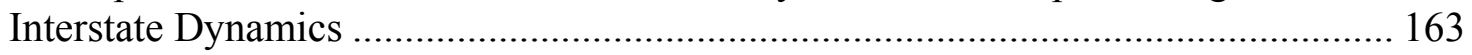

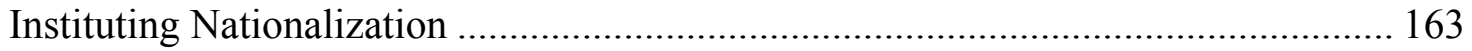

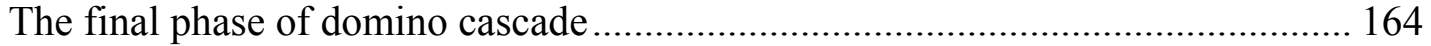

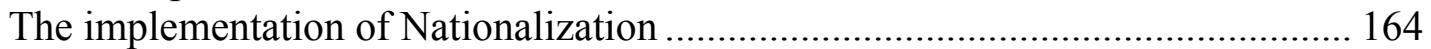

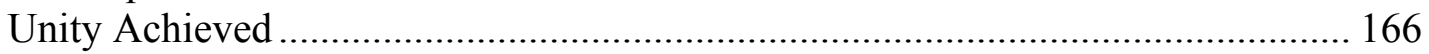

OPEC as a template for the Third World ........................................................... 172

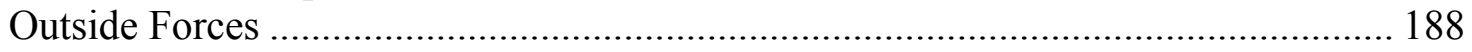

Recognition of Vulnerability leads to Behavioral changes...................................... 188

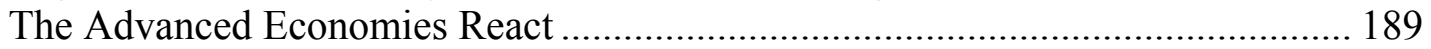

OPEC Unity Challenged, first from within and then from without........................ 196

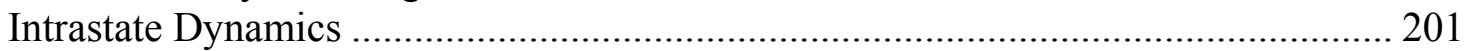

The collapse of the Pahlavi Monarchy in Iran.................................................... 202

The Rise of Saddam Hussein in Iraq................................................................... 206

CHAPTER IV • THE FRAGMENTATION PHASE: OPEC IN CIVIL WAR,

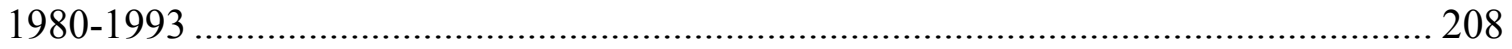

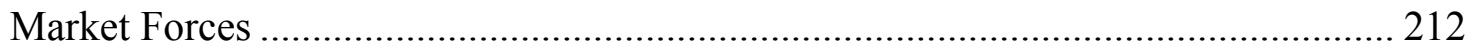

Blowback from OPEC's price hikes: the collapse of its market share domination 221

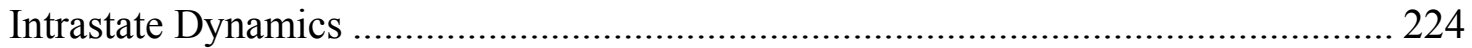

Revolutionary Iran and the establishment of the Islamic Republic ....................... 224

Persian Gulf Arabs React: From Relief to Fear ................................................... 227

The Third Baathist State: Opportunity spurns War …………………………...... 228

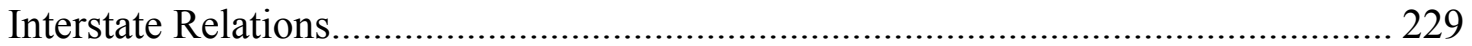

The beginnings of the Iran-Iraq War .............................................................. 230

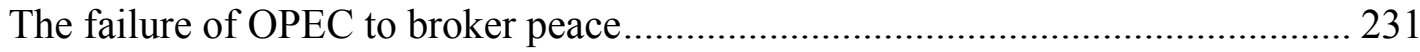

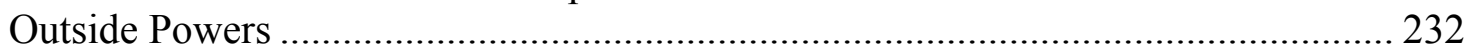

Fearing Revolutionary Iran, the US starts recognition and cooperation with Iraq . 234

Iranian gains in the Iran-Iraq War.................................................................... 237

America's policy shift towards over assistance to Iraq ……................................ 239

Figure 4.6: Total Number of Arms Transfers to Iraq: 1977-1992. Source: Stockholm

International Peace Research Institute ............................................................... 246

The US broadens its Iraq initiative to its regional allies ........................................... 249 


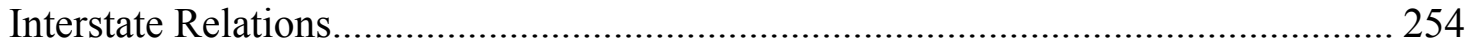

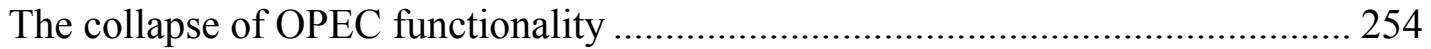

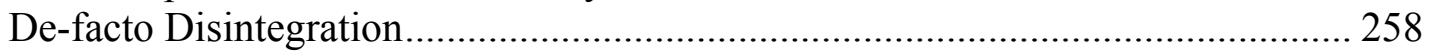

CHAPTER V • THE REBALANCING PHASE, THE GRADUAL

RECENTRALIZATION OF OPEC, 1993-2008 ....................................................... 268

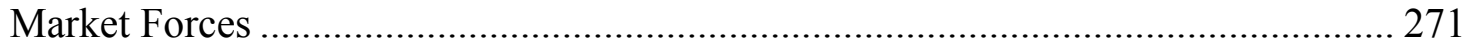

Prolonged ineffectiveness: OPEC in the dark ages, 1993-2000 ........................... 275

Outside Powers ............................................................................................. 282

The opening of the Post-Soviet Space: New Sources of Energy …....................... 284

The New Consumer Base: South and East Asia ................................................. 286

American policy failure: Fallout from interventions in Iraq and Afghanistan ....... 288

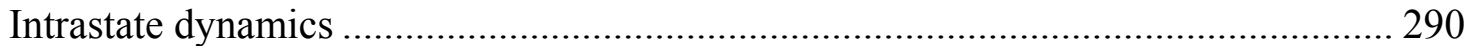

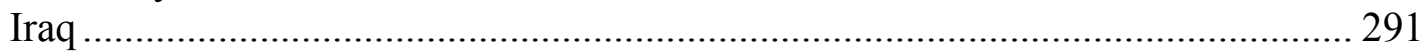

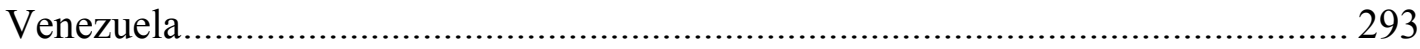

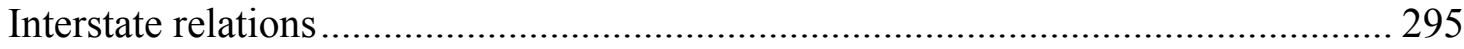

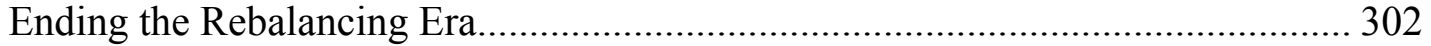

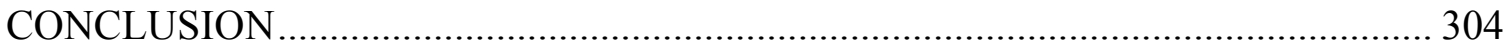

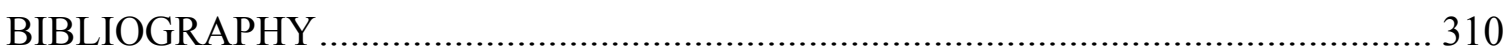

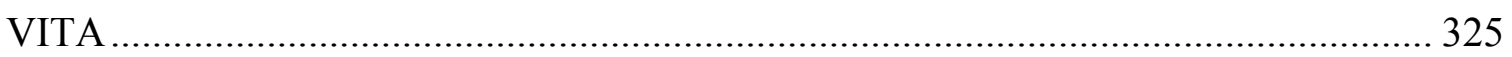




\section{LIST OF FIGURES}

FIGURE

PAGE

Figure 1.1: Post WWI Concession holders in the Iraq Petroleum Company (IPC), the inheritor of the Turkish Petroleum Company ........................................................... 28

Figure 1.2: Saudi Arabia: The pre-ARAMCO concession arrangements........................ 40

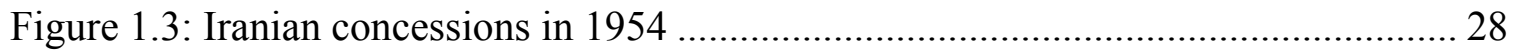

Figure 2.1: OPEC Crude Oil Production by country, as Members joined the

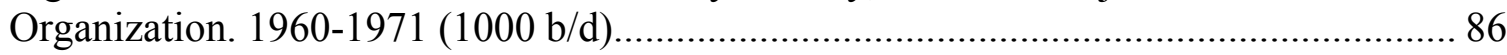

Figure 2.1: OPEC Crude Oil Production by country, as Members joined the

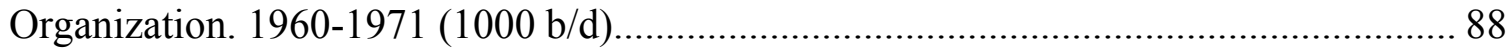

Figure 2.2: Shares of global oil production between OPEC \& non OPEC producers: 1960-1971

Figure 2.3: U.S. Economic Aid to OPEC Member States: 1950-1971

(adjusted to 2011 \$ figures) 97

Figure 2.4: U.S. Military Aid to OPEC Member States: 1950-1971 (adjusted to 2011 $\$$ figures) 98

Figure 3.1: Crude Oil Prices, 1950-1981 (US dollars per barrel) Source: BP Statistical Review 144

Figure 3.2: Global Oil Consumption by Regions: 1965-1981 (Thousand barrels daily) 145

Figure 3.3: OPEC Crude Oil Production by country, as Member States joined the Organization, 1970-1981 (1000 b/d)... 146

Figure 3.4: Shares of global oil production between OPEC and non OPEC producers: 1960-1981 147

Figure 4.1: OPEC Crude Oil Production by country, as Member States joined the Organization, 1978-1993 (1000 b/d)...

Figure 4.2: Global Oil Consumption by Regions: 1965-1993

(Thousand barrels daily).... 215

Figure 4.3: Crude Oil Prices: 1978-1993 (US dollars per barrel) 216

Figure 4.4: Shares of global oil production between OPEC and non OPEC producers: 1978-1993 223

Figure 4.5: Total Number of Arms Transfers to Iran 1977-1992. Source: Stockholm International Peace Research Institute. 245

Figure 4.6: Total Number of Arms Transfers to Iraq: 1977-1992. Source: Stockholm International Peace Research Institute..... 246 
Figure 5.1: OPEC Crude Oil Production by country, as Member States joined the

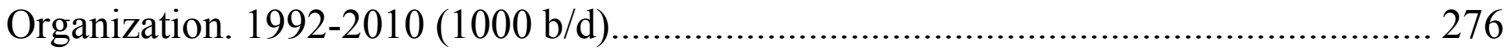

Figure 5.2: Crude Oil Prices: 1990-2011 (US dollars per barrel)

Figure 5.3: OPEC Crude Oil Production by country, as Member States joined the Organization. 1990-2010 (1000 b/d).

Figure 5.4: Global Oil Consumption by Regions: 1965-1993

(Thousand barrels daily) 278 


\section{INTRODUCTION • UNDERSTANDING THE DETERMINANTS BEHIND OPEC'S INSTITUTIONAL BEHAVIOR}

For over half-a-century, the decision-making and behavior of the Organization of Oil Exporting Countries (OPEC) has been a critical area of inquiry for disciplines ranging from economics to security studies. Due to its sustained presence in the global economy and its influence over global oil prices, the ramifications of OPEC's decisions have hovered over many of the research questions posed by scholars while affecting the strategic and policy prescriptions of practitioners. Naturally, the attributes that characterize OPEC and the behavior of the Organization, particularly its internal dynamics, have factored into virtually all, comprehensive assessments of OPEC from its genesis. ${ }^{1}$ Nevertheless, while study of the Organization and its influence upon the global political economy is still a topic of heavy scrutiny, the framework underpinning what OPEC is and the determining factors behind OPEC's actions has now long been conventionalized. $^{2}$

In essence, this conventional understanding of the Organization characterizes OPEC as either a cartel or a sophisticated intergovernmental organization with cartel-like qualities, whose actions, particularly periods of consensus or breakdown, are primarily

\footnotetext{
${ }^{1}$ See: Fariborz Ghadar, The Evolution of Opec Strategy (Lexington, MA: Lexington Books, 1977); Everett M. Ehrlich, "Structural Change in Opec Member Country Production Decisions," OPEC Review 4, no. 4 (1980); Ian Seymour, Opec: Instrument of Change (London, UK: Macmillan, 1980); Theodore H. Moran, "Modeling Opec Behavior: Economic and Political Alternatives," International Organization 35, no. 2 (1981); John Evans, Opec, Its Member States and the World Energy Market (Harlow, Essex, U.K. : Longman, 1986).

${ }^{2}$ Theodore H. Moran, Oil Prices and the Future of Opec: The Political Economy of Tension and Stability in the Organization of Petroleum Exporting Countries (Washington, DC Resources for the Future, 1978).
} 
motivated by the logic of market forces. ${ }^{3}$ Though at times, an acknowledgement of geopolitical factors include the market forces narrative behind OPEC's behavior, much of these analyses have been unsystematic, still centered on the economic logic of supply and demand. $^{4}$

As will be detailed throughout this work, this conventional approach, both the characterization of the OPEC and the understanding behind the determining factors underpinning its behavior, does not capture the nuances of the Organization's internal dynamics, ultimately obscuring a comprehensive picture of OPEC, its decision-making, which proves ineffective in explaining many aspects of its internal and external behavior. In light of this, this analysis seeks to reexamine the central concepts behind what are now the conventional understanding of OPEC, its internal dynamics, and what ultimately determines its behavior. As such two main premises are put forth in this study. The first concerns the traditional understanding of what OPEC is, not in its self-advertised name or what its critics have labeled it, but based upon the functional impact it has had throughout its institutional life. This work argues that OPEC is neither a cartel nor a trade-centered intergovernmental organization, but far more politically-oriented international institution, that while brought together for the explicit purpose of protecting their Members' economic interests as it relates to their export of oil and remuneration that they receive,

\footnotetext{
${ }^{3}$ Ibid; Moran, "Modeling Opec Behavior: Economic and Political Alternatives."; P.V. Hansen and L. Lindholt, The Market Power of Opec 1973 - 2001 (Statistics Norway, 2004); A.L.P. Burdett, Opec: Origins \& Strategy, 1947-1973 (Archive Editions, 2004); Mohammad Baqer Heshmatzadeh, "50 Years of Opec and Politics," Rahbord 20 (60), no. Fall (2011).

${ }^{4}$ See: I. Skeet, Opec: twenty-five years of prices and politics (Cambridge University Press, 1991); Moran, Oil Prices and the Future of Opec: The Political Economy of Tension and Stability in the Organization of Petroleum Exporting Countries; __ , "Modeling Opec Behavior: Economic and Political Alternatives."; Hansen and Lindholt, The Market Power of Opec 1973 - 2001; Burdett, Opec: Origins \& Strategy, 19471973; Heshmatzadeh, "50 Years of Opec and Politics."
} 
its actions cannot be quantified nor explained by the simple, singular logic of economic, profit-motivated rationality. This study argues that OPEC, by reason of the confluence of several factors that have influenced its internal decision-making, its external behavior, and its wider impact upon the global political economy, acts far more as a political forum where economics and politics (domestic, regional, and global) merge, with often times the latter trumping the former.

To understand this phenomenon, the main determinants behind OPEC decisionmaking are examined throughout the institutional life of the Organization. In challenging the established thinking behind OPEC's attributes and behavior, this analysis puts forth a new framework that incorporates 4 disparate, yet interconnected determinants that underpin OPEC behavior. In addition to market forces, the following areas have and continue to produce distinct impact to the internal and external organizational dynamics of OPEC and its wider influence upon the international system: 1.) Outside actor intervention into OPEC (via great powers, multinational corporations, etc.); 2.) Interstate member politics within the Organization (i.e. bilateral relations of member states or coalition building within the Organization); and 3.) the Intrastate dynamics of member states (i.e. the domestic political, social, environmental, and economic scene within individual member states). Collectively, it is argued that the interaction of these 4 variables, provides the ultimate basis and context where OPEC decision/indecision is made, thus producing external behavior.

It is with this framework in mind, that OPEC's history as an international organization, from 1960 to the present, will be examined. In doing so, many of the decisions and actions (and inactions) that OPEC has made throughout its history, either as 
a unitary actor within the international system or a composite organization made up of several differing states, will become more explicable - beyond what the traditional, singularly-focused market forces narrative of the Organization has offered. More so, in running this model through OPEC's institutional life, certain patterns of behavior from its member states, the unitary conception of the Organization, and its relations with outside actors in the international system will provide not only more explanatory power, but predictive capability for OPEC's future.

\section{The Historical Context of Analysis}

Within this study, the institutional life of OPEC will be placed on a historical trajectory that both reveals the political attributes of OPEC beyond the mere economic or cartelbased characterization and also the determinants that have influenced the Organization's behavior throughout time. With over five decades of OPEC behavior in the context of geopolitics and geo-economics, 5 critical periods become dividing lines in the overall evolution of the Organization.

\begin{tabular}{|ccccc|}
\hline \multicolumn{5}{c|}{ Thematic Phases of OPEC's History } \\
\hline Embryonic & Infancy & Ascendancy & Fragmentation & Rebalancing \\
Post WWI - 1959 & $1960-1968$ & $1969-1979$ & $1980-1993$ & $1994-2008$ \\
\hline & & & & \\
\hline
\end{tabular}

The first is the Embryonic phase, which primarily focuses on the pre-OPEC environment in global political economy, the oil industry in particular, and the particular circumstances within each individual OPEC Member State. The second phase is the Infancy, which describes the initial years of OPEC's growth, from its inception in 1960 
and ending in the beginning of the $1970 \mathrm{~s} .{ }^{5}$ The third would be the Ascendancy phase, which witnessed the rise of OPEC on the world stage and the expansion of the Organization outside of the putative cartel label, manifesting the assertion of its geopolitical and geo-economic power from the 1971-73, throughout the 1970s up until the Iran-Iraq war ${ }^{6}$ The fourth is the Fragmentation phase, which many foresaw would be the dramatic weakening and possible disintegration of OPEC. As internal disagreements and, more consequently, open hostilities between member states raged, the first being Iraq against Iran, polarizing inter-member politics within OPEC, only to be exacerbated by outside forces, and later Iraq against Kuwait, which had a similar affect, the notion of consensus could no longer be reached amongst members - only to be compounded by the stagnation in oil prices beginning in the from the mid-1980s. ${ }^{7}$ The fifth is the Rebalancing phase, characterized by not only several important changes within the internal dynamics of member states and their relations with one another, but also the massive macro changes in the global political economy, the most important being the end of the Cold War and disintegration of the Soviet Union. As new, more efficient upstream technologies increased global production by the 'opening' of the former Soviet

\footnotetext{
${ }^{5}$ OPEC's Resolution 90 of June 1968, and the February 1971 Tehran Agreement can be seen as dividing lines from the first phase of OPEC to the second, more assertive phase. See: Chalabi, Fadhil, Oil Policies, Oil Myths

${ }^{6}$ M. A. Adelman, "Is the Oil Shortage Real? Oil Companies as Opec Tax-Collectors," Foreign Policy, no. 9 (1972); Ali M. Jaidah, "Pricing of Oil: Role of the Controlling Power," OPEC Review 1, no. 5 (1977); Ghadar, The Evolution of Opec Strategy; F. J. Al-Chalabi, "A Second Oil Crisis? A Producer's Point of View on the Oil Developments of 1979*," OPEC Review 4, no. 4 (1980); Daniel Yergin, The Prize: The Epic Quest for Oil, Money, \& Power (New York, NY: Simon \& Schuster, 1991); R. Vernon, The Oil Crisis (Norton, 1976).

${ }^{7}$ Y. Ibrahim, The Future of Opec (Middle East Institute, 1984); M.E. Ahrari, Opec: The Failing Giant (University Press of Kentucky, 1986); S. Shojai and B.S. Katz, The Oil Market in the 1980's: A Decade of Decline (Praeger, 1992); M.I. Goldman, Petrostate: Putin, Power, and the New Russia (Oxford University Press, USA, 2010).
} 
Republics, in many cases with assistance from Western states and international oil companies (IOCs), OPEC's impact on the global economy descended into a hibernation phase. Moreover, as the resurrection of Iraq in the international system, from rogue nation to a political order, however fragile, that has access to technology and the wider spectrum of the global markets, which invariably will help it exploit the massive export potential that was denied it by the Baathist political system and the years of devastating wars and sanctions that Iraq went through. Coinciding with this internal Rebalancing has been the continuation of the macro changes since the end of the Cold war: the end of the undisputed unipolar American moment of domination, consequential changes within the Middle East regional power structure, the dramatic rise of oil prices by reason of growing Chinese and Indian economic prowess and the evolution of each OPEC member state. ${ }^{8}$ With this chronological division of OPEC's history providing an aerial picture of the evolution of the Organization, OPEC's attributes and the determinants behind its decision-making and behavior is given crucial context on how and under what conditions they manifest themselves. Thus, a systematic appreciation of the Organization and how it has functioned throughout its institutional life is more readily achieved.

\section{The Conventional Understanding of OPEC}

Cartel vs. Economically-based Intergovernmental organization

\footnotetext{
${ }^{8}$ M. Al-Seghyer, Opec: Tested by Fire - Prepared for the Future; a Review of Its Development, History and an Assessment of Its Effectiveness (University of Exeter, 2000); M. Mazraati and S. M. Tayyebi Jazayeri, "Oil Price Movements and Production Agreements," OPEC Review 28, no. 3 (2004); Marco G. D. Guidi, Alexander Russell, and Heather Tarbert, "The Effect of Opec Policy Decisions on Oil and Stock Prices," OPEC Review 30, no. 1 (2006); E.R. Pitt and C.N. Leung, Opec, Oil Prices and Lng (Nova Science Pub Inc, 2009); Heshmatzadeh, "50 Years of Opec and Politics."; Daniel Yergin, The Quest: Energy, Security, and the Remaking of the Modern World (Penguin Group US, 2011).
} 
The conventional understanding behind the nature of OPEC has been rooted in the initial economic basis of its formation. In viewing the established thinking, OPEC and its decision-making and behavior has essentially been viewed through the lens of two wide subcategories, always underpinned by market forces and the logic of supply and demand. In the first framework, of which was quickly developed early on and in some respects still exists, analysis of the Organization was looked at through the cartel model, ${ }^{9}$ which during times of OPEC effectiveness and consensus, largely viewed the Organization as a unitary actor within the global economy and international system. From the unitary standpoint, the economic motive via the rational model for profit underpinned the major understanding of not only why OPEC came into being, but largely the focus of its operational decision-making throughout time. ${ }^{10}$ Using this cartel logic, a prime example would be instances where low global demand leads to price decreases, bringing about OPEC production cuts, which in turn, is meant to stabilize prices for the benefit of each member's domestic revenue. ${ }^{11}$ Yet in times where consensus was unable to be reached, the unitary framework would give way to a composite understanding of OPEC as a

\footnotetext{
${ }^{9}$ Charles F. Doran, "Opec Structure and Cohesion: Exploring the Determinants of Cartel Policy," The Journal of Politics 42, no. 1 (1980); Richard P. Castanias, "A Test of the Opec Cartel Hypothesis, 19741983: Discussion," The Journal of Finance 40, no. 3 (1985); A. Almoayed, Opec: The Imperfect Cartel (University of Oxford, 1998); James L. Smith, "Inscrutable Opec: Behavioral Tests of the Cartel Hypothesis," SSRN eLibrary (2002); Vincent Brémond, Emmanuel Hache, and Val『rie Mignon, "Does Opec Still Exist as a Cartel? An Empirical Investigation," Energy Economics, no. 0 (2011).

${ }^{10}$ Michael Kennedy, "An Economic Model of the World Oil Market," The Bell Journal of Economics and Management Science 5, no. 2 (1974); Adelman, "Is the Oil Shortage Real? Oil Companies as Opec TaxCollectors."; G.E. Iyamah, Opec Cartel: An Analysis of Its Strength and How to Weaken Its Hold on the U.S. Economy (Morgan State University, 1979); Claudio Loderer, "A Test of the Opec Cartel Hypothesis: 1974-1983," The Journal of Finance 40, no. 3 (1985); Castanias, "A Test of the Opec Cartel Hypothesis, 1974-1983: Discussion."

${ }^{11}$ Iyamah, Opec Cartel: An Analysis of Its Strength and How to Weaken Its Hold on the U.S. Economy; Doran, "Opec Structure and Cohesion: Exploring the Determinants of Cartel Policy."; Albert L. Danielsen, "Cartel Rivalry and the World Price of Oil," Southern Economic Journal 42, no. 3 (1976).
} 
collective entity with varying states with different economic sensitivities, and often times, divergent economic interests. This was the fulfillment of what Raymond Vernon and other economists had long predicted to be the natural demise of cartels, as members invariably diverge based upon their own parochial economic interests, as opposed to the collective's wider, shared interest. ${ }^{12}$ However, gradually a more sophisticated framework developed, viewing OPEC through the lens of an economically-based intergovernmental organization. This view transcended the Organization outside the parochial cartel label, taking on a more nuanced, functionary role for OPEC. ${ }^{13}$ In this framework, while the binary between the unitary and composite nature of OPEC still applies, its actions would be explicable in more functional terms outside the conventional understanding of cartel behavior. From the unitary standpoint, in periods of supply shortage and high demand, the explanation of why OPEC would increase output would not only be for fear that the global economy would transition away to other producers of oil, thus shrinking OPEC member states' market shares, or even from hydrocarbons to alternatives, ${ }^{14}$ but in such circumstances, the collective role of OPEC was seen being a principle custodian of global price stability. In this role, which is principally held by the Organization itself, OPEC's function would be viewed as both merging together the producers' domestic revenue concerns with the apprehensions of the global economy on prices, maintaining the

\footnotetext{
${ }^{12}$ See: Raymond Vernon, The Oil Crisis. Norton, 1976.

${ }^{13}$ Raino Malnes, "Opec and the Problem of Collective Action," Journal of Peace Research 20, no. 4 (1983); Evans, Opec, Its Member States and the World Energy Market; N.D. White, The Law of International Organisations (Juris Pub., 2005); C. Linde, The State and the International Oil Market: Competition and the Changing Ownership of Crude Oil Assets (Kluwer Academic, 2000).

${ }^{14}$ A.M. El-Mokadem, Opec and the World Oil Market, 1973-1983 (Eastlords Pub., 1983); J.W. Plunkett, Plunkett's Energy Industry Almanac 2008 (Plunkett Research, Limited, 2007); G. Luft and A. Korin, Turning Oil into Salt: Energy Independence through Fuel Choice (Booksurge.com, 2009).
} 
equilibrium that perpetuates the global dependence on oil (and more importantly OPEC's market shares) but also acting as a bulwark against volatility. ${ }^{15}$

Yet, in times of consensus failure and gridlock, the composite makeup of the organization would be stressed, being attributable, not just to the parochial member state's focus on their own economic interests, but more by reason of the trappings of bureaucratic or inter-member politics within the Organization, which often led to organizational paralysis and dysfunction. ${ }^{16}$

\section{Why the Cartel and Economically-based Intergovernmental organization labels fall short}

Within both these subcategories, whether OPEC is seen as a unitary actor that acts upon a consensus-based decision, either as a cartel or an economically-based intergovernmental organization, or whether consensus could not be reached by reason of varying economic interests among member states or bureaucratic dysfunction, OPEC decision and behavior has generally been underpinned by market forces. With only a few exceptions, such as Ian Skeet's OPEC: Twenty-Five Years of Prices and Politics published in $1991,{ }^{17}$ the role of politics becomes either minimized or ignored, and virtually never examined in a systemic way. This specifically has to do with the larger geopolitical scene in which the

\footnotetext{
${ }^{15}$ M. Marien, Future Survey Annual 1986: A Guide to the Recent Literature of Trends, Forecasts, and Policy Proposals (Transaction Publishers, 1987); Luft and Korin, Turning Oil into Salt: Energy Independence through Fuel Choice.

${ }^{16}$ Ian Skeet, Opec: Twenty-Fve Years of Prices and Politics (Cambridge University Press, 1991); P. Wonnacott and R.J. Wonnacott, Economics (Wiley, 1990); Steven G. Lanning, "Costs of Maintaining a Cartel," The Journal of Industrial Economics 36, no. 2 (1987); James $\neg \nmid \mathrm{M}$ Griffin and Weiwen Xiong, "The Incentive to Cheat: An Empirical Analysis of Opec," Journal of Law and Economics 40, no. 2 (1997).

${ }^{17}$ Skeet, Opec: Twenty-Fve Years of Prices and Politics; Wonnacott and Wonnacott, Economics; Lanning, "Costs of Maintaining a Cartel."; Griffin and Xiong, "The Incentive to Cheat: An Empirical Analysis of Opec."
} 
Organization operates in, the inter-state politics that seep into the OPEC's organizational dynamics, or the intrastate domestic politics at the national level of each OPEC member. This becomes extremely important when considering that many of OPEC's decisions, its inability of forming consensus, its behavior, or lack of action, are often times inexplicable with the market forces paradigm, both the cartel and economically-based intergovernmental organization models. As will be detailed throughout the study, such primary examples that transcend outside the mere economically based logic of decisionmaking are the following: The Arab Oil Embargo via OAPEC of 1973-74, the Saudi decision to undercut Iran's revenue during the latter days of the Pahlavi dynasty, the Persian Gulf Arab exporters of OPEC ramping up production during the latter stages of the Iran-Iraq war (when oil prices were low); Baathist Iraq's destruction of much of fellow member Kuwait's oil wells in its retreat in the 1991 Desert Storm war; and Saudi Arabia's decision to boost production in 2001-2012 to complement the US sanctions regime on the Islamic Republic of Iran.

The reasoning behind why the traditional framework is simply incapable of explaining certain patterns of behavior that the Organization has exhibited in its institutional life is due to the fact that both the cartel and the economically-based intergovernmental organization labels misconstrue and mischaracterize what OPEC has been in its functional role within the global economy and the international system regardless of the Organization's self-advertised mantra or the labels given to it by both its critics and supporters alike. On the cartel label, while OPEC is certainly a collection major oil exporting states, whose conventional crude oil reserves are roughly $80 \%$ of 
global supply and whose production is roughly $42 \%$ of global production, ${ }^{18}$ it has seldom acted according to the logic of how a cartel operates. A cartel's primary motivation, and thus its raison d'être, is the protection of its market-share. However, OPEC, while cognizant of the importance of protecting its market-share from either other oil-producing competitors or from alternate sources of energy, has never really functioned based upon this principle. In many ways, OPEC's founding was a reaction to what its member states viewed as the abuse of another cartel, specifically how the 'Seven Sisters' (the major IOCs that had oil concessions in OPEC member states) would unilaterally reduce prices or alter production, to protect their own market shares from other competitors in the global oil industry. As the member states that would eventually form OPEC were at the time mere tax collectors whose domestic national revenues would derive from taxing what the IOCs exported from their territories, any reduction of prices or changes in export volume that would lessen what the particular government gleaned from the IOC would be to the detriment of that government's revenues as a whole. Thus, a major catalyst behind why OPEC was formed was price protection from the unilateral decisions of the IOCs, and ultimately to have a say in both prices and export volume. Yet, throughout its history, regardless of the early cognizance of the important of market-share protection, ${ }^{19}$ OPEC decision and behavior gradually became focused on short-term price protection. During the 1970s, with the confluence of factors in the global political

\footnotetext{
${ }^{18}$ See: OPEC Annual Statistical Bulletin 2012 \& other Data figures. http://www.opec.org/opec_web/en/data_graphs/330.htm

${ }^{19}$ In OPEC's Resolution II.6, which laid out the Organization's governing statutes, a clear acknowledgment was made regarding the OPEC's market share juxtaposed to current or future competitors. The efforts were to follow the geological developments, geophysical methods of oil discovery, estimate potential new reserves in the world, and to study the world markets for petroleum consumption trends, transportation of supply, and forecast supply. See: "Resolutions of the Second OPEC Conference". Caracas, 15-21 January 1961.
} 
economy, rising prices were seen, at least from a collective basis, as something positive from the Organization, and thus supported and even exacerbated by many key OPEC members. However, as historians now understand, the dramatic rise in global oil prices was the major reason that led to the shift in alternative sources of energy (particularly nuclear power in Europe and Japan), the entrance of cheaper Soviet oil in the global market, as well expanded upstream activity in more expensive areas of drilling, such as the North Sea. Hence, in supporting price hikes that eventually eroded the Organization's market share, OPEC behaved exactly how a cartel should not. OPEC's collective behavior at times where supply outstrips demand has primarily been focused on shortterm price protection.

Regarding OPEC's characterization as an economically-based intergovernmental organization, there have been several instances in history where the Organization responded to calm rising prices that would eventually lead towards price volatility, and thus avoid damaging the consumer market that the Organization depends upon. Nevertheless, equally or more often, there have also been instances where, due to lack of consensus, OPEC would allow price increases by not collectively raising production levels, with each member state responding differently based upon their particular geopolitical, as well as economic calculations. Often, these geopolitical calculations would come in the form of coalitional formations, with one dominant member, such as Iran or Saudi Arabia, leading a group against another within the Organization. And at other times, collective production levels, even if the economic rationale for profit would favor stemming back exports, such as in the 1980s, became wholly consumed by 
geopolitical calculations that contradicted both the Organization's and individual member states' bottom line.

These discrepancies within what is ostensibly an economic organization render the need to take into account the totality of the political and security contexts it OPEC is embedded in - at the international level, the inter-member level amongst the various OPEC states, and at the domestic, intrastate level or each particular OPEC member. In viewing OPEC through the prism of half-century of behavior, there have been many instances where the conventional framework of OPEC and its behavior has proven insufficient in explaining certain patterns of behavior by its members and, subsequently, the Organization. This is acutely aggravated by the concurrent evolution of OPEC, its individual members, and the international system that the prior two operate in.

\section{A New Framework of Analysis}

In challenging the established thinking behind OPEC behavior, it is argued that the internal mechanisms of the Organization that underpin its behavior, that formulate whether or not consensus is reached, and the external environment that influences its actions are more complex and specifically more politically-oriented than what has traditionally been accepted. While this proposal accepts the logic behind the conventional economic narrative behind OPEC behavior, which is based upon market forces (i.e. supply and demand as being the basis for inter-member cooperation and organizational functionality) this narrative alone cannot fully explain the Organization's internal dynamics and external behavior. Thus, this analysis presents 4 disparate, yet interconnected factors on what influences OPEC behavior, the nexus and interaction of 
which ultimately sets the internal conditions that formulate the climate within the Organization that affects consensus/non-consensus, decision/non-decisions and ultimately, action/inaction.

In addition to market forces, the following areas, while interrelated, produce distinct impacts to the internal and external organizational dynamics of OPEC: 1.) Outside actor intervention into OPEC; 2.) Interstate member politics within the Organization; 3.) Intrastate dynamics of member states. Collectively, it is argued that the interaction of these 3 variables, with that of the conventional economic narrative, provides the logic behind OPEC internal dynamics, which is ultimately the basis and context where OPEC decision/indecision is made, and thus producing external behavior. And while these determinants are distinct, they do not operate in isolation from one another, but display an interactive quality where at times some can be prejudiced over others while at other times all can be identified as having noticeable impact upon decision-making and behavior.

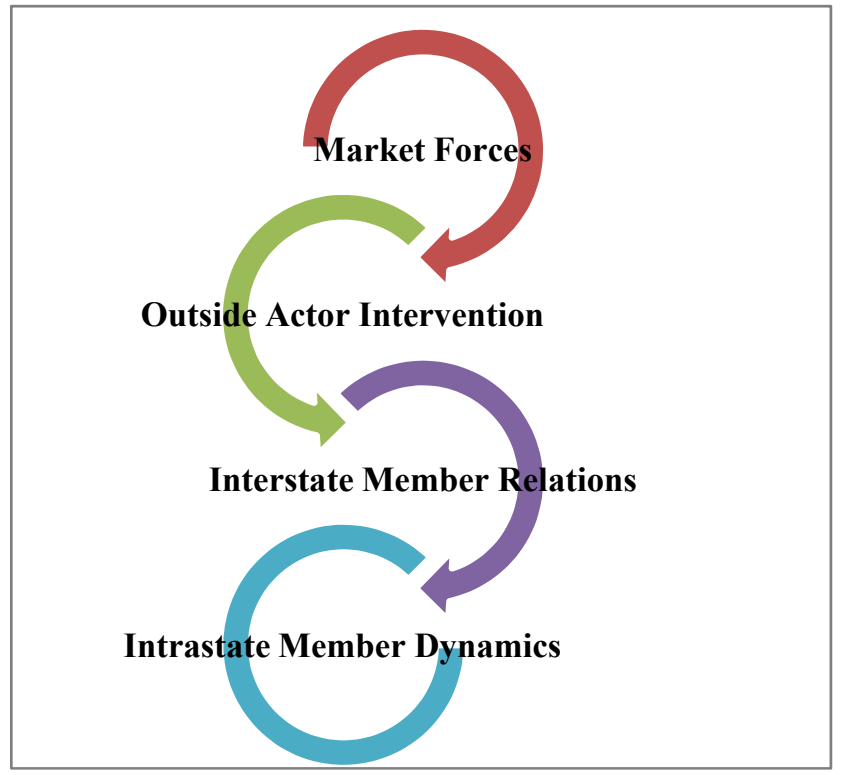

\section{Outside Actor Intervention}

The role of outside actor's, specifically great powers and major multinational corporations (MNCs), upon individual states within the organization has consistently had a noticeable amount of influence upon the overall structure of OPEC's 
internal dynamics, with sustained impact upon the interstate relations between members in general. ${ }^{20}$ At times, this influence ebbed and flowed but its presence always remained. Moreover, as many of OPEC members have had close, intimate ties with great powers, some of which could be characterized as patron-client relations, and major multinational corporations (particularly during the genesis of the petroleum industry in their countries) decision-making by member states, at least tangentially if not out rightly, needed to have some consideration of the aforementioned and their preferences . Furthermore, the relationship between member states and outside actors could be both complimentary, evinced when great powers and MNCs roughly had parallel interests, or in direct conflict, as other times powerful states outside the Organization had conflicting interests with MNCs, with the member state being caught in the middle. Reversibly, interactions with the outside actors, either collectively in the context of the Organization's raison d'être or individually, would be of crucial importance, as the purported "standing" of each member state in the international community, normatively and materially, is invariably affected by it relationship with great powers and major multinationals. As has been witnessed, both these players often facilitate, enhance, or hinder individual OPEC member's systemic access (i.e. 'access' to globalized technology and $\mathrm{R} \& \mathrm{D}$, etc.), while at the same time changing the nature of the internal power makeup and relational context of interaction between OPEC members. Just as like the conventional market driven narrative, this dynamic is and has been a constant throughout the 50-plus year life of the Organization.

\footnotetext{
${ }^{20}$ A.D. Johany, The Myth of the Opec Cartel: The Role of Saudi Arabia (University of Petroleum and Minerals, 1980). N.J. Citino, From Arab Nationalism to Opec: Eisenhower, King Saud, and the Making of U.S.-Saudi Relations (Indiana University Press, 2002). Skeet, Opec: Twenty-Fve Years of Prices and Politics. \& F.S. Al-Saud, Iran, Saudi Arabia and the Gulf: Power Politics in Transition 1968-1971 (I.B. Tauris, 2003).
} 


\section{Interstate Member Relations within the Organization}

The internal relations between member states, the bilateral or multilateral ties between actors within OPEC itself, outside the boundaries of great power relations, is of tremendous importance and carries a logic of its own within the Organization itself. Throughout OPEC's lifespan, issues of bilateral or multilateral concern that are nonpetroleum related that derive from other arenas of either conflict or cooperation between the member states, particularly as it relates to Middle East politics, has bled into the Organization's internal dynamics . As power dynamics have changed throughout the last 50 years, not only on a macro geopolitical level (i.e. from bipolarity, to uni-polarity, to multi-polarity), but also amongst member states themselves, for a whole host of reasons, the politics between or amongst members outside of the OPEC arena, often affects internal and external organizational behavior. As the Middle Eastern political milieu has consistently hovered over the internal deliberations of OPEC members, issues of regional security, highlighted by regional security complex theory, where the politics amongst and between regional states do display certain patterns of enmity and amity, has at times clashed or complicated the national order behind traditional impact of market forces or great power penetration onto OPEC decision-making and behavior. Hence, it is vital to appropriate an independent space of analysis for the role of inter-member relations, and the continuities and changes within these relations and the impact of these relations upon the Organization throughout its lifespan.

\section{Intrastate Member Dynamics}

The internal political, social, economic, and even environmental dynamics that have evolved within the individual member states of OPEC throughout the Organization's 
lifespan have proven consequentially influential on internal organizational decision and behavior. The changing nature or consistency of the political systems of each OPEC member state, not only affect the domestic politics and economic scene within that particular country, but also affect the climate of how that state has access to that technology (i.e. individual member's extraction, production capacity, and research and development). The ideological underpinnings behind a member state's regime typology have had major implications for the power and influence they yield within the Organization. Is the state a status quo power? Is it a revolutionary power? Throughout the history of the Organization, members have passed the gauntlet of political changes that have swept their domestic political fronts, and thus their interstate relations within the organization changed, which eventually affected internal consensus dynamics and external behavior. Some important examples can be clearly seen in the transformation of Baathist Party in Iraq and its subsequent rise and fall, the transformation of Libyan domestic dynamics from King Idris to Moammar Qaddafi to the latter's downfall in 2011, to the Iranian Revolution and its, to US occupation of Iraq, and ultimately the continuing integration of GCC states into one unitary union .

Concerning production capacity, $\mathrm{R} \& \mathrm{D}$, and reserve amounts, the amount of effort into exploration, drilling efficiency, and spare production capacity that each member state has allocated from their domestic budgets have massive and consequential impacts upon their power and influence within OPEC, and thus do affect inter-member relations, internal organizational dynamics, and often their relationships with great powers. States, such as Saudi Arabia and monarchial Iran, who put much effort in this endeavor, eventually became major players within the Organization. Yet, when a member lost this 
"edge", such as Baathist Iraq or Qaddafi controlled-Libya, due primarily to political change and a denial of systemic access, their influence within the Organization suffered, thus changing the context in which decision was made, and ultimately OPEC behavior. Moreover, the amount of hydrocarbon reserves, in both quantity and quality, which a member state has under its territory, is not a neutral factor either, for reserve figures throughout OPEC's history has fluctuated. A distinctive pattern within OPEC has emerged that indicates that members with larger reserves, more allocation to $R \& D$, spare capacity production, eventually attain more clout and power within the Organization, which affects decision making. 


\section{CHAPTER I • THE EMBRYONIC PHASE: THE RISE AND FALL OF THE CONCESSIONARY SYSTEM \& THE BIRTH OF OPEC}

The members of OPEC came from extremely diverse backgrounds, located in different parts of the globe, with varying histories, political systems, languages, cultures, domestic economies, and geopolitical alliances and relations. Even their individual national experiences with the rise of the global oil industry were vastly different from one another other, as some members became enmeshed in hierarchical concessionary agreements to major international oil companies (IOC), often with consent from a great power, while others experienced more favorable conditions within the concessionary system as junior partners. But regardless of the disparities amongst them, three broader attributes that each shared, united their collective experience and ultimately laid the foundation for OPEC's formation: all were members of the developing world with little power in international institutions as well as being militarily weak, all had substantial amount of hydrocarbon reserves in their territory that they did not have dominion over, and all, in the years prior to OPEC's formation, had their economies, of which oil exports to varying degrees was a major factor, negatively impacted by forces outside their control.

Within the environment preceding OPEC's entrance on the world stage, a confluence of factors at the national, interstate, and international levels ultimately led to the group's configuration. These factors, while ostensibly economic in nature, chiefly as it relates to price and volume of the oil exports from what eventually became OPEC members, also had a major geopolitical and strategic genesis. What led to OPEC's formation was only partially economic in nature, specifically a reaction by the developing world's exporters to the lack of price and export control that existed in the global oil 
industry in the late 1950s. However, there were also important geopolitical factors at work as well. OPEC's formation happened in the aftermath of the wave of independence movements within the developing world, which invariably left indelible marks in regions that great powers had dominated, primarily the Middle East, North Africa, and to a lesser extent Latin America. ${ }^{21}$ Moreover, OPEC's birth happened in the midst of a bipolar international system dominated by the US and the USSR, where virtually every domestic and regional development, particularly, in the developing world, was viewed by great powers through the zero-sum logic of Cold War dynamics. ${ }^{22}$ Internally within OPEC states, as the revenue from oil exports made up a sizeable portion or even the brunt of member states' economies, the survivability of the political regimes in power and even the cohesion and continuance of certain post-colonial states lay in the balance, many times inviting intervention by regional actors or great powers, whose home multinational firms had a major interest in petroleum-endowed developing countries.

Accordingly, to understand the Organization's creation, it is crucial to link the larger macro influence of market forces in the context of the geopolitical dimensions of great power rivalries, the changing nature of the global oil trade, the internal political and economic dynamics within the states that became members of OPEC, and later, their relations with one another. This chapter lays out the environment before the Organization's formation, the first decade of OPEC's institutional life, and how powerful

\footnotetext{
${ }^{21}$ See: D. Fromkin, A Peace to End All Peace: The Fall of the Ottoman Empire and the Creation of the Modern Middle East (H. Holt, 2001), 43. \& D. Little, American Orientalism: The United States and the Middle East since 1945 (University of North Carolina Press, 2008).

${ }^{22}$ Odd A. Westad, The Global Cold War: Third World Interventions and the Making of Our Times (Cambridge University Press, 2005); M.P. Leffler, For the Soul of Mankind: The United States, the Soviet Union, and the Cold War (Farrar, Straus and Giroux, 2007).
} 
outside forces dealt with OPEC's formation, both the great powers and the major international oil companies, with the domestic political and socioeconomic realities within the states that would eventually became OPEC members.

\section{The geo-economic and geopolitical context}

\section{Creating the Home-IOC-Host triangle}

At the dawn of the globalization of the oil industry, when exploration and production began the expansion outside the initial American and Russian centers, the growing international oil companies (IOC) quickly understood the significance of market share accumulation, from the upstream component to the downstream consumer level. This was seen initially in the domestic US and Russian contexts in which they operated and their

eventual ventures abroad. This expansion had its genesis at the beginning of the $20^{\text {th }}$ century, in the major shift in strategic thinking as it related to energy transportation and for the major economies of the world - specifically the mass transition from coal to crude oil. As with many future technologies that eventually spread to societies writ large, the invention of the internal combustion engine quickly became a key area of interest to the militaries of major powers. As Leonardo Maugeri has catalogued, crude oil's attractiveness lay in the following qualities: its 1.) Higher thermal efficiency, enabling large vessels to 'travel faster and cover greater distances while enjoying greater selfsufficiency" 2.) Versatility of use, in that "with oil a ship could be refueled while underway, whereas the loading of coal required a ship to stop in ports equipped with the necessary facilities'; and 3.) Storage, in that 'oil products were far simpler to store and 
move once on board than coal, ' requiring less space and significantly fewer personnel. ${ }^{23}$ As the major economies of the day, gradually grasped the efficiencies and benefits of oil and its clear advantage over coal, which up until that time, had been the lifeblood of the $19^{\text {th }}$ century's economy, grand strategies of the world's major powers now shifted to having access to this vital commodity. In doing so, the major powers, took a new or renewed interest in the activities of their still nescient multinational oil companies that were based out of their respective territories. And either by default and design, the foreign acquisition activities of oil firms based in their countries, which was profitmotivated, came to be mutually reinforcing with the strategic imperatives of great powers, not just for their economies, but to enhance their military might. The result, as the unique characteristics of crude oil elevated it from being just another commodity to a crucial factor in grand strategy, military dominance, and economic vitality, was that the home governments of these multinational oil firms, such as the US, France, and Britain, became enmeshed in their firms' foreign dealings in their hunt for oil.

What would become the major catalyst for the grand strategic shift towards crude oil was World War I, and its immediate aftermath, as petroleum products 'emerged as the leading fuels for moving people, armies, airplanes, and naval fleets throughout the world.'

${ }^{24}$ Moreover, the dramatic increase of oil consumption during the war caused world markets and the major powers to augment their concern about supply and access, even spurring a decline in confidence in American crude reserves, though the US was still

\footnotetext{
${ }^{23}$ L. Maugeri, The Age of Oil: The Mythology, History, and Future of the World's Most Controversial Resource (Abc-Clio Incorporated, 2006), 22.

${ }^{24}$ Ibid., 24.
} 
major exporter of crude oil. ${ }^{25}$ Compounded by the increase in consumption because of the War, what exacerbated concern was the October 1917 Bolshevik Revolution in Russia and the devastating civil war from 1917-1920, which dramatically cut production from Russia and within months, led to full nationalization of Russia's oil fields in June of 1918. ${ }^{26}$ Realizing the extent that political and economic volatility in a major producing countries could impact access to supplies, creating shortages and mass panics, the international oil companies, already engaged in broadening their acquisition and production activities outside their home countries, accelerated the pace - in Latin America, and more consequentially, the Middle East, where the brunt of conventional petroleum reserves are located. ${ }^{27}$ It was this initial catalyst that not only laid the groundwork for the home government/IOC/host government nexus, and the complications that it brought, but also, the future coordination between the international oil companies, to protect their market shares, which later became a consequential factor in the creation of OPEC.

\section{The Companies scramble}

\section{Creating the Concession System}

In the Middle East, even before the anticipated demise of the Ottoman State, once its disastrous entry into WWI ended its political viability as a unitary state, diverse European powers, including Russia and the United States, had become aware of the large

\footnotetext{
${ }^{25}$ Mira Wilkins, "The Oil Companies in Perspective," Daedalus 104, no. 4 (1975): 159-61.

${ }^{26}$ See: Goldman, Petrostate: Putin, Power, and the New Russia, 24. \& Sheila Fitzpatrick, The Russian Revolution (New York Oxford University Press, 1982. 1994).

${ }^{27}$ Mira Wilkins, "Multinational Oil Companies in South America in the 1920s: Argentina, Bolivia, Brazil, Chile, Colombia, Ecuador, and Peru," The Business History Review 48, no. 3 (1974): 425-26. \& Maugeri, The Age of Oil: The Mythology, History, and Future of the World's Most Controversial Resource, 26-32.
} 
amount of oil deposits in the frontiers beyond the Turkish Empire, in Iran, and its former colonies in the Caucus, particularly in and around the Caspian city of Baku. ${ }^{28}$ Once the Ottoman Empire was dismantled by force by the victorious British and French in the aftermath of WWI, 'enormous new commercial opportunities throughout [its] former territories' now lay open for both private European enterprise as well as the national designs of their home states. ${ }^{29}$ For years, various entrepreneurs of European, and later American origin, traveled to the Ottoman territories and Iran in search of lucrative business opportunities in the newfangled petroleum industry. ${ }^{30}$ Eventually, these individual missions, because of the confluence of regional circumstances, were able to obtain significant concessions in developing states, becoming the forerunners for the entrance of powerful European and US multinational firms. ${ }^{31}$

With the centrifugal forces intrinsic to the decaying Ottoman Empire, compounded by its consequential loss in the first World War, dramatically disintegrating the state, for the first time in the history of the collective memory of the contemporary Middle East, the once bifurcated political design that comprised two stable Ottoman and Iranian states morphed into a 21-state sub-system, comprising of a weak Iran, a truncated Turkish Republic, later a resurrected Jewish entity, with newly created Arab states that were mostly vassals and protectorates of the British and French. ${ }^{32}$ Suffice it to say,

\footnotetext{
${ }^{28}$ Goldman, Petrostate: Putin, Power, and the New Russia, 17-24.

${ }^{29}$ R. Howard, The Oil Hunters: Exploration and Espionage in the Middle East (Bloomsbury, 2008), xi.

${ }^{30}$ Ibid., 1-22.

${ }^{31}$ See: V. Marcel and J.V. Mitchell, Oil Titans: National Oil Companies in the Middle East (Chatham House, 2006). Howard, The Oil Hunters: Exploration and Espionage in the Middle East; Yergin, The Prize: The Epic Quest for Oil, Money, \& Power.

${ }^{32}$ K. van der Pijl, Global Rivalries from the Cold War to Iraq (Pluto Press, 2006), 43.
} 
juxtaposed to the "centuries of domination in Latin America and South Asia, the period of formal European colonialism in the Middle East was short-lived' as the 'Ottoman territories appropriated after World War I were given independence within a decade or two. ${ }^{33}$ However, sovereignty, either for newly created entities with no history of a political culture or for weakened states in transition, such as Iran, with feeble civil institutions and a corrupt ruling apparatus, was quite an elusive notion. As such, this reality ebbed into every aspect of governance, particularly the state's economic dealings. In this new regional reality, the economic designs of the British, French, and later the Americans, while at times being visibly antithetical to each other, were now mostly unimpeded by any indigenous forces within the developing states that possessed large amounts of hydrocarbon reserves.

Reeling from internal political turmoil and edging closer to state bankruptcy, the first noteworthy Middle Eastern oil concession was made by the Iranian Qajar court to British businessman, William D'Arcy in 1901. Whether by reason of extreme naïveté or desperation, the Shah of Iran gave exclusive rights for vast swaths of Iranian territory for oil exploration and production for the next 60 years, in exchange for a paltry $£ 20,000$, an equal amount in shares of D'Arcy's company, and a promise of $16 \%$ of future revenue. ${ }^{34}$ Coincidentally, this was the same Qajar court that a decade earlier had granted a monopolistic concession for the entire handling, buying, and selling of all tobacco raised in the country to a British firm, eliciting massive public discontent to the point that the concession was revoked a short time later. Yet, though the weak Qajar potentate was

\footnotetext{
${ }^{33}$ F. Halliday, The Middle East in International Relations: Power, Politics and Ideology (Cambridge University Press, 2005), 82.

${ }^{34}$ S. Kinzer, All the Shah's Men: An American Coup and the Roots of Middle East Terror (Wiley, 2011), 48.
} 
virtually stripped of most kingly powers in Iran's constitutional revolution in 1906, the newly formed parliament found itself devoid of any meaningful liquid assets in the national treasury, and thus, the concessions to D'Arcy remained. ${ }^{35}$ After years of toil in the Iranian hinterland, William D'Arcy discovered that his own funds were drying up, and in a last ditch effort to save his enterprise, he combined investments in Iran with the British-owned Burma Oil Company in 1905. ${ }^{36}$ After striking the first well in 1908, the first payment of $£ 2,900$ came to a cash-strapped Iranian government in the years of 1912-13. ${ }^{37}$ With now tangible proof that Iran contained oil, this allowed D'Arcy to continue his business endeavors, transforming Burma Oil into the Anglo-Persian Oil Company (later to be renamed the Anglo-Iranian Oil Company, the modern day British Petroleum).

As 'the world's great industrial and military powers', realized that unlike other commodities and resources, oil was an unique strategic asset for the long-term advancement and economic, political, and military aggrandizement of their nations, both domestically and globally, they implemented policies to control 'critical strategic resources as an advantage over their geopolitical and economic competitors. ${ }^{38}$ For this reason, Iran, like many of its neighbors and other developing states with large quantities of oil reserves, quickly transformed into an arena of confrontation amongst the major powers, often times in collaboration with powerful multinational oil firms. ${ }^{39}$ For the

\footnotetext{
${ }^{35}$ E. Abrahamian, A History of Modern Iran (Cambridge University Press, 2008), 54-56.

${ }^{36}$ Marcel and Mitchell, Oil Titans: National Oil Companies in the Middle East, 16.

${ }^{37}$ Abrahamian, A History of Modern Iran, 55.

${ }^{38}$ Marcel and Mitchell, Oil Titans: National Oil Companies in the Middle East, 14.

${ }^{39}$ Abrahamian, A History of Modern Iran. \& Yergin, The Prize: The Epic Quest for Oil, Money, \& Power.
} 
British, noticing that a domestic firm had unimpeded access to large quantities of this strategic resource was an opportunity that had to be harvested, protected, and exploited. This strategic repositioning merely coincided and, in many ways, was a response to the British Royal Navy's decision to convert its warships from coal-fired boilers to diesel motors, prompting London to acquire a 51 percent interest in D'Arcy's enterprise. ${ }^{40}$ Britain's fateful decision, providing 'a monopoly over Iranian oil for the next forty years', ${ }^{41}$ to be maintained at all cost, despite indigenous resistance that witnessed a change of Iranian dynasties, massive internal modernization efforts, and transformational regional events, ${ }^{42}$ essentially marrying the national interests of the empire, the profit motivations of the firm (Anglo-Iranian), with internal events within Iran. In other words, there now was clear link between domestic Iranian politics and socio-economics, the profitability of the Anglo-Iranian Oil Company, and the domestic and international interests of one of the globe's superpowers. Although initially, the British were focused on obviating Russian/Soviet attempts at forcing concessions upon the feeble Iranian court, fearing that any concession may undermine its own interests in the country, (only to be proven later by kinetic Soviet attempts at occupying Iranian territory in World War II), London's efforts quickly moved to quelling any indigenous nationalistic tendencies at concessional revisionism, which became a hallmark of the Iranian government's dealings with the UK and the US, in nationalization attempts in 1933, 1953, up until undisputed total dominative control in the OPEC era.

\footnotetext{
${ }^{40}$ Little, American Orientalism: The United States and the Middle East since 1945, 46.

${ }^{41}$ Ibid.

${ }^{42}$ Abrahamian, A History of Modern Iran, 63-96. S.A. Arjomand, The Turban for the Crown: The Islamic Revolution in Iran (Oxford University Press, 1988), 34-69.
} 
The interaction between Iran, its internal dynamics, and the great powers in the height of geopolitical factors disallowed any firm to enter into the Iranian state, granting the Anglo-Iranian Oil Company, buttressed by British military, economic, and diplomatic might, total and complete monopoly over all of Iranian energy. Within this dynamic, a weak Iranian state, trapped in the contours of power politics, became incapable of mustering the negotiating power to alter its fortunes. It was this dynamic, also evident in other developing, oil-endowed countries, that formed the underlying basis for the internal modernization and later nationalization efforts that would be witnessed intermittently in the decades ahead.

\section{Expanding the Concession System in the Middle East}

As developments were progressing in Iran, and partially spawned by AngloIranian's successful efforts, German firms were garnering simultaneous interest in the Ottoman Mosul province. Just as the British synthesized attempts to maximize domestic corporate profits with the national security interests of the state, German entrepreneurs began a rigorous campaign at exploration in establishing the Turkish Petroleum Company (TPC). ${ }^{43}$ Albeit, as war broke out in August of 1914, only to be followed by Germany's defeat four years later, all Turkish rule over what later became Iraq, fell under Allied control. Naturally, Anglo-Iranian and Royal Dutch Shell, a hybrid Dutch/British venture created a little more than a decade earlier, 'gained a controlling interest in the TPC', while turning Germany's share over to France. ${ }^{44}$ As the limbs of the former Ottoman state were being strewn to France and Britain, the mandate that the League of Nations set

\footnotetext{
${ }^{43}$ Maugeri, The Age of Oil: The Mythology, History, and Future of the World's Most Controversial Resource, 27-28. Little, American Orientalism: The United States and the Middle East since 1945, 46.

${ }^{44}$ Little, American Orientalism: The United States and the Middle East since 1945, 46.
} 
forth allocated Syria and Lebanon to France while Britain controlled Jordan, greater Palestine, and Iraq, with Turkey, Yemen and what would later become Saudi Arabia, emerging as independent entities. ${ }^{45}$

In this geopolitical flux, the US, under the Wilson administration, realized that

Figure 1.1: Post WWI Concession holders

in the Iraq Petroleum Company (IPC), the inheritor of the Turkish Petroleum

\section{Company}

$$
\begin{gathered}
\text { Royal-Dutch } \\
\text { Shell } \\
23.75 \%
\end{gathered}
$$

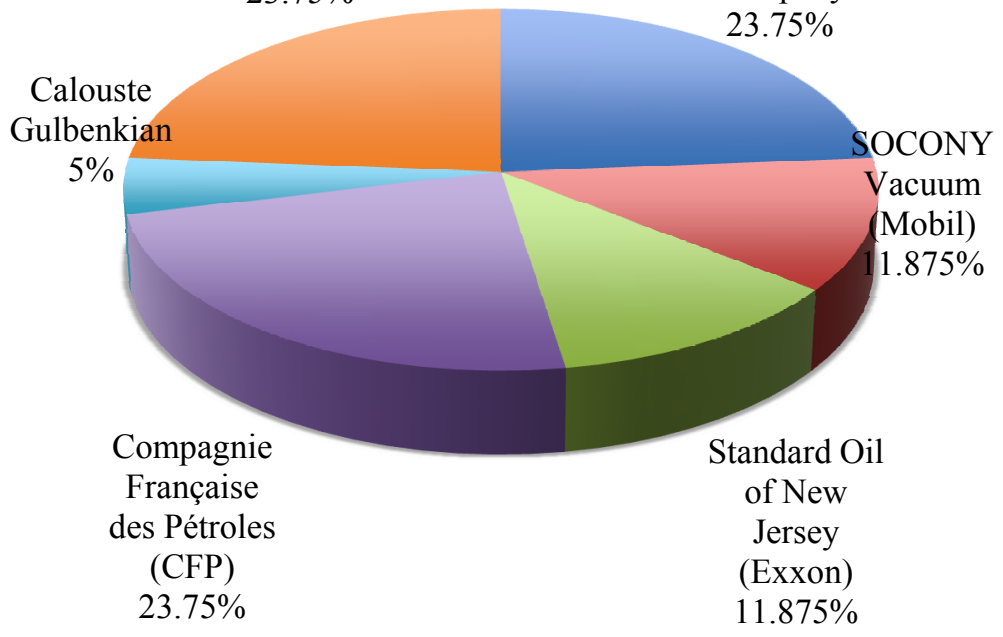

sole European attempts at dominating large tracts of oil-endowed territory would have a possible long-term impact on US energy needs and would surely disadvantage domestic corporate profit potential, with the possibility of leaving the US in an vulnerable position. ${ }^{46}$ This was only to be reinforced by the secretive San Remo

agreement, which temporarily precluded any American multinational from the petrospoils of the Great War. ${ }^{47}$ For its part, France, realizing the strategic value of oil,

\footnotetext{
${ }^{45}$ M. Kamrava, The Modern Middle East: A Political History since the First World War (University of California Press, 2011), 43-47.

${ }^{46}$ Yergin, The Prize: The Epic Quest for Oil, Money, \& Power, 194-95.

${ }^{47}$ Little, American Orientalism: The United States and the Middle East since 1945, 46.
} 
although later than its counterparts, traded 'some of its Syrian territorial interests' in exchange for the French IOC, Compagnie Française des Pétroles (CFP), the ancestor of Total, to take part in the TPC. ${ }^{48}$ Having been formed in 1924 on the Paris government's initiative, but 'wholly administered by private interests', CFP was proof that regarding oil, the synthesis of domestic private enterprise with the national interests had now been adopted by the French.

Within Washington, this mixture had a direct impact upon policy. The Standard Oil Company of New York (SOCONY) was particularly adamant about being included into what was rapidly becoming a multi-party affair, persuading 'the State Department to step up its pressure on the British to permit U.S. multinationals to buy into the TPC consortium. ${ }^{49}$ With Britain having de-facto say on the business climate in the embryonic Iraq, and fearing economic retaliation by Washington, the terms were negotiated into allowing US partners. Therefore, SOCONY and Jersey Standard split a 23.75 percent share of IPC stock while Anglo-Iranian, Royal Dutch Shell, and CFP received 23.75 percent respectively. ${ }^{50}$ The remaining 5 percent was allocated to Calouste Gulbenkian, a former Ottoman subject, "who had helped win the original concession from the Turks. ${ }^{51}$ Moreover, in a move to further quell the US government, the British agreed to a joint venture between Anglo-Iranian and the American Gulf Oil into their Kuwait protectorate.

\footnotetext{
${ }^{48}$ Marcel and Mitchell, Oil Titans: National Oil Companies in the Middle East, 17.

${ }^{49}$ Little, American Orientalism: The United States and the Middle East since 1945, 46. Maugeri, The Age of Oil: The Mythology, History, and Future of the World's Most Controversial Resource, 27-28.

${ }^{50}$ Francisco Parra, Oil Politics: A Modern History of Petroleum (I.B. Tauris, 2004), 32.

${ }^{51}$ Little, American Orientalism: The United States and the Middle East since 1945, 46.
} 
${ }^{52}$ Within a short amount of time, TPC was conveniently relabeled the Iraq Petroleum Company (IPC), to represent the region's new political realities.

The wrangling between the diverse IOCs, their home governments, and the administrators of the new state of Iraq proved to be a watershed moment in the interaction and cooperation within the emergent home-IOC-host nexus, creating, within a relatively short time, a 'global map'... of 'cross border company interests supported by a concentration of the oil industry. ${ }^{53}$ As the network between home, host, and the IOCs became more complex, 'competition between exporting countries could take place only through competition between the international oil companies, ${ }^{54}$ garnering a collection of strange bedfellows. This was evinced by the sudden glut in international petroleum supply. The great panic caused by WWI, the subsequent scramble of the IOCs into Latin America and in the Middle East, and the rebound of Russian/Soviet exports from the instability caused by the October Revolution of 1917 had so succeeded into bringing additional supply into the global oil market, that nearing the end of the 1920s, prices had decreased extensively. As the global oil market became saturated, fearing profit reduction and in attempt to ward off other oil-seeking entrepreneurs and firms from future exploration opportunities, the participants of the IPC in July of 1928, with tacit approval of all home governments, designated a zone, known as the Red Line ${ }^{55}$ around 'the

\footnotetext{
${ }^{52}$ Parra, Oil Politics: A Modern History of Petroleum, 8.

${ }^{53}$ Marcel and Mitchell, Oil Titans: National Oil Companies in the Middle East, 19.

${ }^{54}$ Ibid.

55 "The "Red Line" Agreement of 1928 was an agreement among the companies that jointly owned the Iraq Petroleum Company, namely BP, Shell, CFP, Exxon, Mobil and Partex (Gulbenkian). Under its terms, none of the signatory companies were permitted to acquire concession interests in any of the areas of the Middle East delineated on a map by a red line that included Turkey and only excluded Iran, Kuwait and the Saudi Arabian-Kuwaiti Neutral Zone.' See: Parra, Oil Politics: A Modern History of Petroleum, 348.
} 
prewar Ottoman Empire, an area that included Iraq and Saudi Arabia but not Iran or Kuwait,' with a gentlemen's agreement that all members would refrain from seeking new concessions inside the settled territory without the approval of the consortium as a whole. ${ }^{56}$ However, as market saturation only increased, only months later, in September of 1928 , the major IOCs Standard Oil of New Jersey, Anglo-Iranian, and Royal Dutch Shell, met in Achnacarry in Scotland, UK and set up the "As-Is" or Achnacarrry Agreement, to coordinate oil output in order to organize the market, in an effort to halt the decrease of prices and bring about market stabilization. ${ }^{57}$ To do so, companies agreed on a quota system in differing markets, according to the their respective percentage shares of consumer consumption in a respective country, and would only increase oil output if total demand rose - again, based upon their particular shares. ${ }^{58}$ These efforts, nonetheless, were futile as too many intervening factors, both economic and political, undercut any real sustained impact from collaboration of the three major IOCs. Amongst the most consequential were the Wall Street crash in 1929, the interwar economic crisis within Europe, the Great Depression, the large oil discoveries in East Texas in 1930-31, the advancing nature of the technological efficiency in oil extraction and refinement, and rudimentary efforts at conversation from the major economies of the world, all of which, in combination, led to unprecedented decline in global oil prices. ${ }^{59}$

\footnotetext{
${ }^{56}$ Little, American Orientalism: The United States and the Middle East since 1945, 47.

${ }^{57}$ A. Sampson, The Seven Sisters: The Great Oil Companies and the World They Shaped (New York: The Viking Press, 1975), 74-75.

${ }^{58}$ Yergin, The Prize: The Epic Quest for Oil, Money, \& Power.

${ }^{59}$ Wilkins, "The Oil Companies in Perspective," 160.; Maugeri, The Age of Oil: The Mythology, History, and Future of the World's Most Controversial Resource, 41-46., \& Yergin, The Prize: The Epic Quest for Oil, Money, \& Power, 260-79.
} 


\section{The Seeds of Nationalization and the beginnings of the 'domino cascade'}

The resulting 1930s oil glut and collapse in prices set off a chain of events that would forever remake the architecture of the global oil industry, altering the nature of the interaction between the developed world and oil-endowed countries of the developing world. As previously mentioned, while the concessionary agreements led to an interactive nexus of cooperation amongst the major IOCs, often backed by their great power home states, what the 1930s oil collapse engendered was the rise of the 'domino cascade' of nationalization attempts and concessional revisionism from host governments, as one producing country's actions would set precedent, in which other producing countries would either learn from, directly mimic, and/or integrate in their national energy export strategies. Virtually no producing country could ignore the tremors of this tectonic shift. And as the IOCs, with the great powers, responded to each case rather differently, the slow process of power transfer gradually began from the IOCs to producing countries, although the road was long and arduous. The end of that road was OPEC.

\section{The Mexican Catalyst}

The genesis of the host state pushback, incidentally, happened not in some remote corner of the world where the US and European powers had little control over, but in the what was traditionally seen as America's backyard, Latin America - more curiously, in Mexico. It is here where the importance of what transpired between the Iranian Qajar court and British entrepreneur William D'Arcy manifests again. As the early hunt for oil spread into Latin America, another British entrepreneur, Weetman Pearson, an expert engineer in large-scale national infrastructural projects, was invited by Mexican President Porfirio Diaz and commissioned to aid Mexico's development plans, chiefly in national 
railways and canals. ${ }^{60}$ However, in the course of time, Pearson discovered that Mexico possessed large oil reserves, and therefore, shifted from being a foreign commissioned engineer to becoming Mexico's D'Arcy. In approaching Mexican President Diaz, the Iranian concession agreements to D'Arcy acted as a template for how Pearson would set up the arrangement for extracting Mexican oil. As Leonardo Maugeri has pointed out, the concession arrangements that Pearson agreed upon with Mexico 'followed the scheme set up by D'Arcy in Persia and would set the model for all eventual contracts in Mexico: a modest royalty for every ton of oil produced, a tax on surface occupation, no income tax, and the direct ownership of subsurface findings. ${ }^{61}$ However, though Pearson's Mexican oil venture, Mexican Eagle, successfully crafted many of the mechanisms that defined that country's oil industry, he decided, just like D'Arcy in Iran, to merge his company with a larger IOC, eventually selling his company to Royal Dutch Shell near the end of WWI, which added to the further homogenization of the global oil industry under the domination of the major IOCs. ${ }^{62}$

But for Pearson, profit motivation in selling Mexican Eagle was not the only factor. The massive political instability caused by the Mexican Revolution of 1911, and the uncertainty in that country's business climate certainly altered his perception about continued investment. The immediate post-WWI oil scramble, nevertheless, made the major IOCs more risk averse than their smaller competitors, and thus Royal Dutch Shell's takeover of Mexican Eagle, and the huge potential for profit, rendered its mass entrance

\footnotetext{
${ }^{60}$ Yergin, The Prize: The Epic Quest for Oil, Money, \& Power, 230.

${ }^{61}$ Maugeri, The Age of Oil: The Mythology, History, and Future of the World's Most Controversial Resource, 30.

${ }^{62}$ Yergin, The Prize: The Epic Quest for Oil, Money, \& Power, 231-33.
} 
into Mexico a worthy gambit. Yet with time, Royal Dutch Shell would experience firsthand that even a major IOC with an army of human capital, endless resources, and substantial geopolitical clout with the great powers, was not immune to a developing country's alacrity towards concessionary agreements that it felt was imposed upon it by an unpopular government in cahoots with a foreign firm. In 1917, though the central Mexican government had its heads of states removed intermittently by reason of continued political turmoil, the post-Diaz parliament collectively voted to extend the central government's writ over all Mexican resources, including oil. ${ }^{63}$ Immediately, the IOCs, Royal Dutch Shell being the largest, took notice and fought back against the Mexican government. As negotiations reached a deadlock, due to both sides' irreconcilable positions, and fearing that continued instability would make normal operations within Mexico very difficult, the major IOCs decided to gradually cut back and even halt certain operations in the country, and look south to Venezuela, where more hospital conditions prevailed. As Daniel Yergin has chronicled, the government of Juan Vicente Gomez of Venezuela was not only unusually cruel and authoritarian, but more importantly, Venezuela under Gomez had very little domestic institutions that were not fully controlled by Gomez and his family. ${ }^{64}$ Thus, this rendered Venezuela an attractive place for IOCs as foreign firms only needed permission from one small segment of the country's elite, as opposed to waiting for parliamentary decision-making or even popularly based consensus from the ballot box. ${ }^{65}$ And just as Mexico's Diaz years before

\footnotetext{
${ }^{63}$ Maugeri, The Age of Oil: The Mythology, History, and Future of the World's Most Controversial Resource, 30.

${ }^{64}$ Yergin, The Prize: The Epic Quest for Oil, Money, \& Power, 235-36.

${ }^{65}$ Ibid.
} 
him, Venezuela under Gomez, essentially adopted D’Arcy's Iranian model of concession agreements with Royal Dutch-Shell holding the brunt of Venezuela's oil concessions.

With the oil glut of the 1930s however, the home-IOC-host nexus in Latin America started to unravel. Early in the 1920's, Argentina managed to nationalize its own oil industry, but due to the insignificance of Argentinean oil exports to global supply, there was virtually no long-term impact to the other host producing countries and little reaction from the bourgeoning concession system that the major IOCs were building. Mexico was a different case altogether. Before the fall of Mexico's Diaz and the IOCs southern migration into Venezuela, its exports were very substantial for the US and global economies. As some semblance of political stability took hold with the beginning of Lazaro Cardenas' presidency, the central Mexican government, once again, sought to tighten its control of Mexican oil. Like many developing countries, the impact of the Great Depression, particularly on the Mexican oil industry, was very debilitating. Early in the Cardenas presidency, as oil workers went on strike to protest for better pay and working conditions, the Mexican government overtly supported the workers against the IOCs. ${ }^{66}$ Buoyed by the prospects of having a Venezuelan alternative to Mexican oil, the IOCs hardened their positions. As "tit-for-tat" recriminations were lobbied from one side to the other, President Cardenas abruptly nationalized all seventeen companies that were operating within Mexico - a move that shocked the IOCs and the global oil industry writ large. ${ }^{67}$ The IOCs had previously figured that due to the political instability unleashed by

\footnotetext{
${ }^{66}$ Sampson, The Seven Sisters: The Great Oil Companies and the World They Shaped, 85.

${ }^{67}$ See: Government of Mexico, Mexico's Oil: A Compilation of Official Documents in the Conflict of Economic Order in the Petroleum Industry, with an Introduction Summarizing Its Causes and Consequences (Government of Mexico via The University of Michigan 1940 (digitized August 2006)). \& Sampson, The Seven Sisters: The Great Oil Companies and the World They Shaped, 86.
} 
Mexico's revolution, the normal operating conditions that they were accustomed to were not present in Mexico, rendering operations within that country more difficult, which increased the importance of alternative sources, namely Venezuela. Moreover, as prices were at historic lows, the IOCs also assumed that the Mexican government would be far more dependent on them for export and pricing, and hence more pliable, as opposed to periods where supplies were tight and demand was high. Yet, total state expropriation was something that very few expected, especially in such an important producer country. Once nationalization became a reality, the majors, both individually and collectively, sought help directly from their home governments - a pattern of behavior that would be exhibited many more times to come. It was only with the US government's reaction to the Mexican expropriation that acted as the catalyst for the domino cascade of concessional revisionism. Based upon his administration's “Good Neighbor” policy, which essentially came to signify a reworking of the US relationship with its much weaker neighbors in the Western Hemisphere, ${ }^{68}$ President Roosevelt chose not to intervene on behalf of American IOCs in Mexico. Without the US backing its firms in Mexico, the other IOCs, most notably Royal Dutch Shell was unable to obtain sufficient British and Dutch support to challenge Cardenas in a meaningful way.

Mexico's nationalization, though successful, came with a heavy short-term price. Most of the high skilled engineers and operation managers from the IOCs immediately left the country. PEMEX, the new Mexican national oil company, had to rebuild a new managing echelon to substitute the tremendous amount of the industrial brain drain that

\footnotetext{
${ }^{68}$ G.C. Herring, From Colony to Superpower: U.S. Foreign Relations since 1776 (Oxford University Press 2009), 497-500.
} 
had left. Nevertheless, the successful nationalization created a powerful and enduring precedent for the other producing countries in the developing world. Half-way across the globe from the Middle East, the news of Mexico's nationalization brought intrigue to Middle Eastern countries, including to vociferous Iran, whose 1933 ill-fated nationalization attempt under the Shah Reza Pahlavi had the left the monarch partially humiliated. Just like Mexico, the global economic downturn and the subsequent Great Depression dramatically plummeted oil prices, which cause the governments of producing countries to agitate for more control over their oil. In the Iranian case, the host government was far too weak to stand up to Anglo-Iranian and their British backers. Yet for Mexico, the timing was a great contributing factor to its nationalization success, in addition to the fact that it was dealing with a more sympathetic US government, as opposed to a recalcitrant Britain. Having transpired on the eve of World War II, and born out of the same vein of concern, Mexico's nationalization provoked a new sense of caution amongst IOC executives and their home governments. It was at the height of the World War II in 1943, where the fear of a domino effect materialized in Venezuela, when the countries oil industry underwent a 'thorough reorganization', 'spurred on by a number of different factors of which pressure for higher taxes' on foreign firms was an 'important one.' ${ }^{69}$ Fearing a Mexican repeat, the US actively chose to midwife the negotiations, which produced a much more compliant, though determined Venezuelan initiative. Throughout the deliberations, the principle Venezuelan concern was the readjustment of tax laws, which ultimately made all multinationals liable at 12 percent,

${ }^{69}$ Parra, Oil Politics: A Modern History of Petroleum, 14. 
crossing all sectors of industry. ${ }^{70}$ Coincidentally, the Caracas government was looking to implement the same the relationship with foreign multinationals that the U.S. had with the foreign firms that leased oil rights offshore or on federal American land. In successfully doing so, 'Venezuela's sovereign right to set the rate of income tax was established', using its newly acquired power to 'increase the rate of corporate tax in 1947 so that the total "government take" of royalties and tax would always be $50 \%$ of the profits', while the IOCs would retain the other $50 \% .{ }^{71}$ This arrangement became official in 1948. And while the Caracas government was overthrown in a military coup shortly afterward, unlike the Iranian case where oil agreements often vacillated with particular regimes, the 50/50 template that was born in Venezuela ultimately remained. ${ }^{72}$

Whether the Venezuelan case was a result of the original concessional framework, the Caracas regime's adept negotiation skills, or Washington's fear of an impact on global oil supply during a time of war, in all probability, all of the aforementioned variables were contributing factors in how a developing state secured its rights from powerful multinationals and the world's great powers by non-violent means. Nonetheless, as word of the 50/50 profit sharing arrangement swept the Middle East, it elicited different reactions from all parties concerned, with the Americans ambivalent, resigning themselves to an inevitable Venezuelan type outcome, the British strongly resisting, while each host state attempted to reconcile the Venezuelan precedent in their own dealings with the IOCs.

\footnotetext{
${ }^{70}$ Marcel and Mitchell, Oil Titans: National Oil Companies in the Middle East, 20.

${ }^{71}$ Ibid.

${ }^{72}$ Parra, Oil Politics, 16.
} 


\section{The spread of the 50/50 arrangement}

While events in Mexico and later in Venezuela set the precedent for the 50/50 arrangement between IOCs and host governments, it was WWII, and its immediate aftermath, particularly the Korean crisis and the beginnings of mutual antagonism between the US and USSR that created the context for its expansion. Just as WWI created the major scramble for oil by IOCs, the beginning of WWII resurrected the specter of possible shortages and supply disruption to the advanced economies of the major world powers. As a result, the IOCs renewed their efforts to secure new sources of supply, particularly in the Middle East. For firms left out of concessionary arrangements in the Iraq Petroleum Company (IPC), especially American multinationals, such as Standard Oil of California (SOCAL) or Texaco, this was a prime opportunity to recoup what they had lost when the doors of the IPC closed. As exploratory efforts were underway in the Persian Gulf island of Bahrain, US IOCs looked to the new Kingdom of Saudi Arabia, which in 1933 SOCAL had signed a concession agreement for exploration. In a joint venture that produced the California Arabian Standard Oil Company, or CASOC (later to become the Arabian American Oil Company, or ARAMCO), SOCAL and Texaco began to rapidly expand exploratory efforts, which eventually paid off when oil in commercial quantities was discovered in the Kingdom in $1938 .{ }^{73}$

Furthermore, as the war clouds over Europe loomed once more, US concerns on supply and future access to energy were again resurrected, boding well for the SOCAL/Texaco venture as Washington once again displayed intense interventionist

\footnotetext{
${ }^{73}$ Citino, From Arab Nationalism to Opec: Eisenhower, King Saud, and the Making of U.S.-Saudi Relations, 1-38.
} 
behavior in hopes of keeping the foreign concessions solely for American firms. ${ }^{74}$ Subsequently, to entice the new Saudi government, 'on the initiative of the State Department, supported by SOCAL and Texaco, President Franklin Roosevelt declared Saudi Arabia eligible for American Lend-Lease assistance in February 1943', with a tacit quid pro quo offer that, in no uncertain terms, proposed that the joint SOCAL/Texaco enterprise 'would create an oil reserve in Saudi Arabia whose contents would be made available to the U.S. government at prices below those on the world market' in exchange for future loans and credit. ${ }^{75}$ Nevertheless, Washington's ostensive involvement had its limits, with a failed attempt to create an Anglo-American Agreement, which many feared would result in a joint British-American cartel. As a result, the US, like its European counterparts, utilized its multinationals as vehicles for the state's interest.

As production in Saudi Arabia grew, it was soon realized by the newly formed

Figure 1.2: Saudi Arabia: The preARAMCO concession arrangements

The Texas

Oil

Company

(Texaco)

$30 \%$

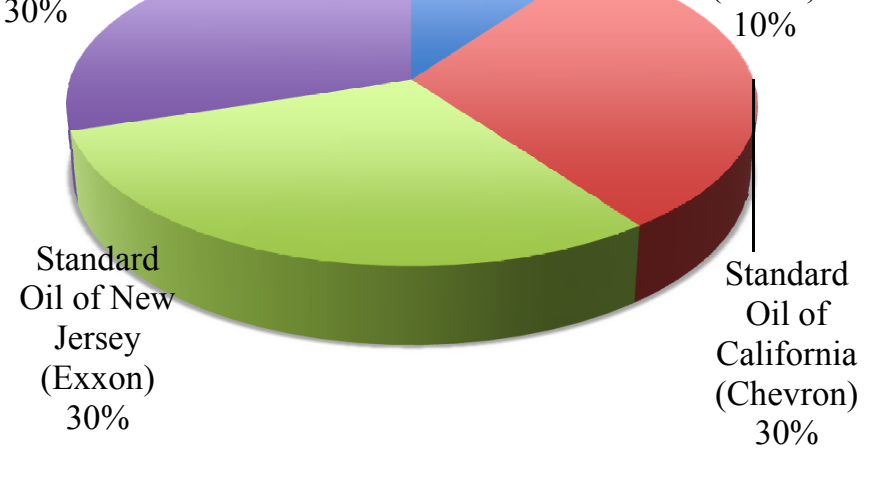

venture that both SOCAL and

Texaco would need additional capital, along with 'markets and political clout' to undertake the successful operation in un-tapping the vast Arabian Desert. ${ }^{76}$ Standard Oil

\footnotetext{
${ }^{74}$ R.O. Keohane, After Hegemony: Cooperation and Discord in the World Political Economy (Princeton University Press, 1984, 2005), 151-52.

${ }^{75}$ Ibid.

${ }^{76}$ Parra, Oil Politics: A Modern History of Petroleum, 8.
} 
of New Jersey and SOCONY, both firms that were bound to the IPC, were in such a position to meet that need, with Jersey chronically suffering from limited access to crude, and 'concerned about being excluded from the richest, lowest-cost concession in the world. ${ }^{77}$ Yet, as both Jersey and SOCONY were bound to the IPC and the Red Line Agreement, an overt violation would set bad precedent. Notwithstanding, this did not dissuade Washington, and behind the scenes, though with strong objections from the French, 'the terms worked out among the IPC members dissolved the Red Line Agreement', however leaving the skeptical French the right to 'draw larger shares of oil from IPC production than their proportionate holdings in IPC would have allowed. ${ }^{78}$

Eventually, what became ARAMCO, a sole multi-party American concession, allocated $30 \%$ to Standard Oil of California, Texaco, and SOCONY respectively, with $10 \%$ provided for SOCONY. With the end of hostilities in Europe, only to be followed by the beginnings of the US-USSR Cold War, the US government took an active role in the relationship that American IOCs had with the Saudi government. ${ }^{79}$ Fearing Soviet designs on Middle Eastern oil, which had been recently manifested in the Azerbaijan crisis in Iran, where the Soviet military only grudgingly withdrew from Iranian territory by reason of American pressure, ${ }^{80}$ the US increasingly became sensitive to the legitimate

\footnotetext{
${ }^{77}$ Keohane, After Hegemony: Cooperation and Discord in the World Political Economy, 152.

${ }^{78}$ Ibid., 157.

${ }^{79}$ United States. Congress. Senate. Special Committee Investigating Petroleum Resources, American Petroleum Interests in Foreign Countries: Hearings before a Special Committee Investigating Petroleum Resources, United States Senate, Seventy-Ninth Congress, First Session, Pursuant to S. Res. 36 (Extending S. Res. 253, 78th Congress) a Resolution Providing for an Investigation with Respect to Petroleum Resources in Relation to the National Welfare. June 27 and 28, 1945 (U.S. Government Printing Office via ARNO Press, A New York Times Company 1946, 1976), 24-25; 182-87; 340-41.

${ }^{80}$ See: State Archive of Political Parties and Social Movements of the Republic of Azerbaijan, Baku (GAPPOD AzR), f.1, op. 89. d.104. Obtained by Jamil Hasanli. Translated for CWIHP by Gary Goldberg.
} 
concessionary grievances from producing countries and the possibility of Soviet exploitation of those grievances. And as Francisco Parra has explained, by reason of this concern, the US figured that more favorable concessionary arrangements for the host governments 'were desirable and probably inevitable after the adoption of 50/50 in Venezuela,' and thus, the 50/50 arrangement that US IOCs and Saudi Arabia eventually agreed upon 'became a well-orchestrated joint undertaking of ARAMCO, its parent companies, the US State Department and the US Treasury, designed to offer to Saudi Arabia promptly and voluntarily what many recognized would sooner or later have to be conceded throughout the Middle East. ${ }^{81}$ This made Saudi Arabia the first regional country to adopt the 50/50 profit sharing arrangement, which only a few short years later spread to both the Iraq and Kuwait consortiums, despite British reluctance. ${ }^{82}$

\section{Changes in the Imperial roles in the Middle East and 50/50 challenged in Iran}

When news of the 50/50 arrangement that American IOCs, in collaboration with the US government made with Saudi Arabia, reached Tehran, it both enraged and emboldened the Iranian government. Shah Reza Pahlavi’s ill-fated nationalization attempt in 1933, five years prior to Mexico's, and his 1941 forced abdication of the throne and subsequent exile by the British and Soviet invasion of Iran in the midst of WWII, had severally antagonized all segments of Iranian society by reason of the constant intervention in Iranian domestic affairs, and stringent hold that Britain, through Anglo-Iranian, had on Iranian oil.

(06/21/1945). \& L.L.E. Fawcett, Iran and the Cold War: The Azerbaijan Crisis of 1946 (Cambridge University Press, 1992).

${ }^{81}$ Parra, Oil Politics: A Modern History of Petroleum, 17-18.

${ }^{82}$ See: A. Burdett, Opec Origins and Strategy 1947-1973 6 Volume Set (Archive Editions Limited, 2004), Volume 1: 1947-59. 
Under these conditions, after decades of attempting to incrementally change the structure of the original concession, 'Iranian resentment against the British oil monopoly flared into full-scale confrontation. ${ }^{83}$ While Iranian methods were reactionary, their stipulations were quite banal. Tehran, witnessing the 50/50 paradigm being offered and eventually adopted by the major host countries, "called for legislation forcing AngloIranian to split its profits with Iran fifty-fifty, as ARAMCO had recently done across the Persian Gulf in Saudi Arabia. ${ }^{84}$ The initial British reaction was to fully reject the Iranian government's demands, confidant that Mohammad Reza Pahlavi, who they helped install after the forced exile of his father, was able to confront nationalist Iranian politicians calling for expropriation. However, as protests only grew, under newly elected Prime Minister Mohammad Mossadegh, just like the Mexican nationalization under Cardenas, the oil nationalization issue had evolved to being one of national sovereignty and independence. And while the British only later grudgingly accepted terms to negotiate, possibly to arrive at the inevitable $50 / 50$ profit sharing arrangement that had become the norm in the concessionary system, delays on their part and the mutual recriminations from one side to another had already unleashed the desire for full nationalization - just as in Mexico.

Yet, the Iranian expropriation was dissimilar from what Cardenas managed to do in 1938, which ultimately rendered a completely different response from the major IOCs and their host governments. While both Iranian and Mexican oil had significant impact upon global supply and the roots of their respective governments' nationalization

\footnotetext{
${ }^{83}$ Little, American Orientalism: The United States and the Middle East since 1945, 56.

${ }^{84}$ Ibid.
} 
attempts were generally the same, the context in which the nationalization's occurred were very different, ultimately leading to vastly different outcomes. The first important difference was the nature of the concessionary system in Iran, as opposed to other host states. While in Saudi Arabia, Iraq, Kuwait, along with their Latin American counterparts, there existed the presence of several IOCs, often times from differing home countries, which allowed the respective host government to varying degrees to play one off against another, Anglo-Iranian's exclusive concession left the Iranian government alone to negotiate with a powerful IOC, backed by the dominant British government and her allies. Furthermore, as Anglo-Iranian was the sole concession holder in Iran, other IOCs, whether the majors or smaller independent firms, were either to weak or unwilling to challenge Britain's prevailing position in Iranian oil. What this eventually created, which coincided and was exacerbated by the immense importance that the British Royal Navy placed in Iranian crude, was a British dependency on a subdued and strangulated Iranian state, with little control over its resources. These concessionary arrangements and the dependency that Britain had on Iran did not exist in Mexico from other IOCs or home governments.

The second major difference was timing. Mexican nationalization occurred on the eve of WWII, where the major economies were concerned about supply shortages and access. Due to this concern, as mentioned previously, the home governments of the IOCs operating in Mexico, particularly the US, chose to cautiously approach the Mexican nationalization as not to antagonize the government, ultimately accepting the outcome of Mexico's actions and the subsequent Venezuelan initiative that was the catalyst for the 50/50 paradigm of profit sharing. This helped dampen concerns and avoid the crippling 
supply disruptions that so many feared. Iranian nationalization, however, both its 1933 attempt and its successful implementation in 1951, transpired at a time of relative global political stability and in eras of low oil prices, where the concerns of supply shortages, access, and prices were almost nonexistent. This evoked far less sympathy for the Iranian government's decision by the home governments of the major IOCs. In other words, unlike Mexico or Venezuela, Iran had no advocate within the international system. And while the US initially attempted to mediate between the two parties, because of Britain's insistence, ${ }^{85}$ and the overarching fear that the US had of supposed communist elements within Iran, the US ultimately sided with London and Anglo-Iranian. ${ }^{86}$

The third major difference was geographic in nature, in that Iran's borders with the USSR automatically evoked tremendous American and European anxiety regarding Soviet designs on Middle Eastern oil - which considering Moscow's behavior towards Iran during the immediate aftermath of WWII, was clearly logical. So deep and pervasive was this concern, and heavily influenced by Iranian nationalization in 1951, that the US and the UK began to develop a joint policy of "oil denial" in the Middle East, in the event that hostile forces, whether intrinsic to the host producing country or foreign in nature, such as a Soviet invasion, would attempt to take over oil production in a respective oil producing state, chiefly in those states that the US and European IOCs were operating in.

\footnotetext{
${ }^{85}$ R. O'Connor, The Oil Barons: Men of Greed and Grandeur (Little, Brown, 1971), 364-94.

${ }^{86}$ In a CIA memo to President Eisenhower in 1953, the perception of the US government towards events in Iran is clearly viewed through the prism of Cold war geopolitics and supposed Soviet influence in the country. Much focus is allocated to the rise of the Iranian Tudeh party, what that would mean for US influence in Iran, Soviet regional influence, the effects on the Cold War, and Iranian exports in general. See: CIA memo to the President re Iran situation, March 1, 1953 [NSC Staff Papers, Box 65, Disaster File, $\operatorname{Iran}(3)]$
} 
${ }^{87}$ Under the oil denial agreement, the US and UK had devised sabotage plans for the 'removal of key parts, destruction of stocks and demolition of surface facilities ...that would be usable by an enemy', in which two 'variations' were sketched out: 'a selection of targets for destruction that will render the facilities unusable and un-repairable by an enemy for a period of 6-12 months and a selection of priority targets for destruction under "crash conditions".' ${ }^{88}$ In destroying or severally debilitating the oil fields' functionality and the equipment for extraction and transport, two main objectives would become theoretically feasible: rendering void, at least for the short term, Soviet acquisition of key oil wells and reserves in a host producing country and in the event that hostile domestic forces in a host producing country would obtain power, acquiring new leverage over the new political order. Eventually, the US and UK divided responsibilities for these contingent plans, with the former being responsible for the Arabian Peninsula while the latter would be responsible for affairs across the Persian Gulf in Iran and Iraq.

With these in mind, it is important to note that while the UK and US ultimately arrived at an agreed approach towards Iranian nationalization, particularly the Mossadegh-led government, and their initial individual assessments of the situation when nationalization became reality in February of 1951 was vastly different. As Anthony Sampson has noted, the US, under the Truman administration, was unsympathetic to

\footnotetext{
${ }^{87}$ See: NSC Progress Report on NSC 26 Series, "Removal and Demolition of Oil Facilities, Equipment and Supplies in the Middle East," March 9, 1953 [OSANSA, NSC Series, Policy Papers Subseries, Box 1, NSC 26/2-5 Middle East Oil] \& NSC Progress Report on NSC 26 Series, "Removal and Demolition of Oil Facilities, Equipment and Supplies in the Middle East," August 7,

${ }^{88}$ NSC Progress Report on NSC 26 Series, "Removal and Demolition of Oil Facilities, Equipment and Supplies in the Middle East," March 9, 1953 [OSANSA, NSC Series, Policy Papers Subseries, Box 1, NSC 26/2-5 Middle East Oil]
} 
Anglo-Iranian's refusal to even consider what the grievances of their host government, ${ }^{89}$ which partly was a residue of FDR's approach to Mexico and Venezuela. But with the arrival of the Eisenhower administration, the escalation of the US-USSR Cold war subsumed any empathy towards the Iranian position, as the home governments, particularly the US and the UK, forcefully supported the position of the majors. The British response to Iranian nationalization, particularly before a joint UK-US strategy could be devised, was to apply a crippling boycott and denial of Iranian oil in the market. During this time, Anglo-Iranian's middle management team in the Abadan oil refinery in Iran and in other oil fields in the country had either left the country or stopped working altogether. Thus, with the boycott and the severe decline in oil revenues, the Iranian government quickly became destabilized and vulnerable to external manipulation. During the two-year boycott, particularly near the latter end, the British, in collusion with the US as playing the lead role, utilized the growing frustration of the populace against Mossadegh's premiership, as the boycott of Iranian oil was having devastating effect upon the Iranian economy. Under the leadership of Kermit Roosevelt, Jr., a CIA political action officer, and in collaboration with Iranians loyal to the monarchy's accommodationist position on Iranian oil and its relations with Western powers in general, the US and the UK orchestrated Operation Ajax in August of 1953, using largely paid mobs to storm the Prime Minister's office and demanding his resignation. ${ }^{90}$

With public discontent bowling over because of the deteriorating economic conditions within the country, and having now faced visible signs of opposition amongst

\footnotetext{
${ }^{89}$ Sampson, The Seven Sisters: The Great Oil Companies and the World They Shaped, 124-26.

${ }^{90}$ A. Milani, The Shah (Palgrave Macmillan, 2011), 171-202; G.R. Afkhami, The Life and Times of the Shah (University of California Press, 2009), 155-86.
} 
the pro-monarchial elite within the country, with no great power in the international system that was sympathetic to his nationalization policies, Mossadegh was forced to resign, and spent the remainder of his days in house arrest, permanently exiled from politics. Though the ramifications of the coup against Mossadegh would be fully seen decades later in the Iranian Revolution of 1979, the American and British perceptions of the events of August of 1953 viewed the "success" of the coup through solely the Cold War prism. In his Presidential Diaries reflecting on Operation Ajax, US President Eisenhower clearly manifested this perception, while also acknowledging the economic reality that Iran faced after the coup, chiefly in the global oil market:

Another recent development that we helped bring about was the restoration of the Shah to power in Iran and the elimination of Mossadegh. The things we did were "covert." If knowledge of them became public, we would not only be embarrassed in that region, but our chances to do anything of like nature in the future would almost totally disappear. Nevertheless our agent there, a member of the CIA, worked intelligently, courageously and tirelessly... Now if the British will be conciliatory and display some wisdom; if the Shah and his new premier, General Zahedi will be only a little bit flexible, and the United States will stand by to help both financially and with wise counsel, we may really give a serious defeat to Russian intentions and plans in that area. Of course, it will not be so easy for the Iranian economy to be restored, even if her refineries again begin to operate. This is due to the fact that during the long period of shut down of her oil fields, world buyers have gone to other sources of supply. These have been expanded to meet the need and now, literally, Iran really has no ready market for her vast oil production. However, this is a problem that we should be able to help solve. ${ }^{91}$

While it has conventionally been understood that the British government and Anglo-Iranian (BP), came out as "winners" from the 1953 coup against Prime Minister Mossadegh, in reality, there were no winners, but varying degrees of losers. The coup

\footnotetext{
${ }^{91}$ DDE Diary Notes (page 10 re Iran), October 8, 1953 [DDE's Papers as President, DDE Diaries Series, Box 4, DDE Diary Oct.-Dec. 1953]
} 
was a setback for Iranian democracy, indelibly maligned Britain's image in Iran and the region, began the cycle of mistrust of the US by the Iranian public and a large segment of the Iranian elite, and from a material standpoint, dramatically lessened Anglo-Iranian's sway over Iranian exports.

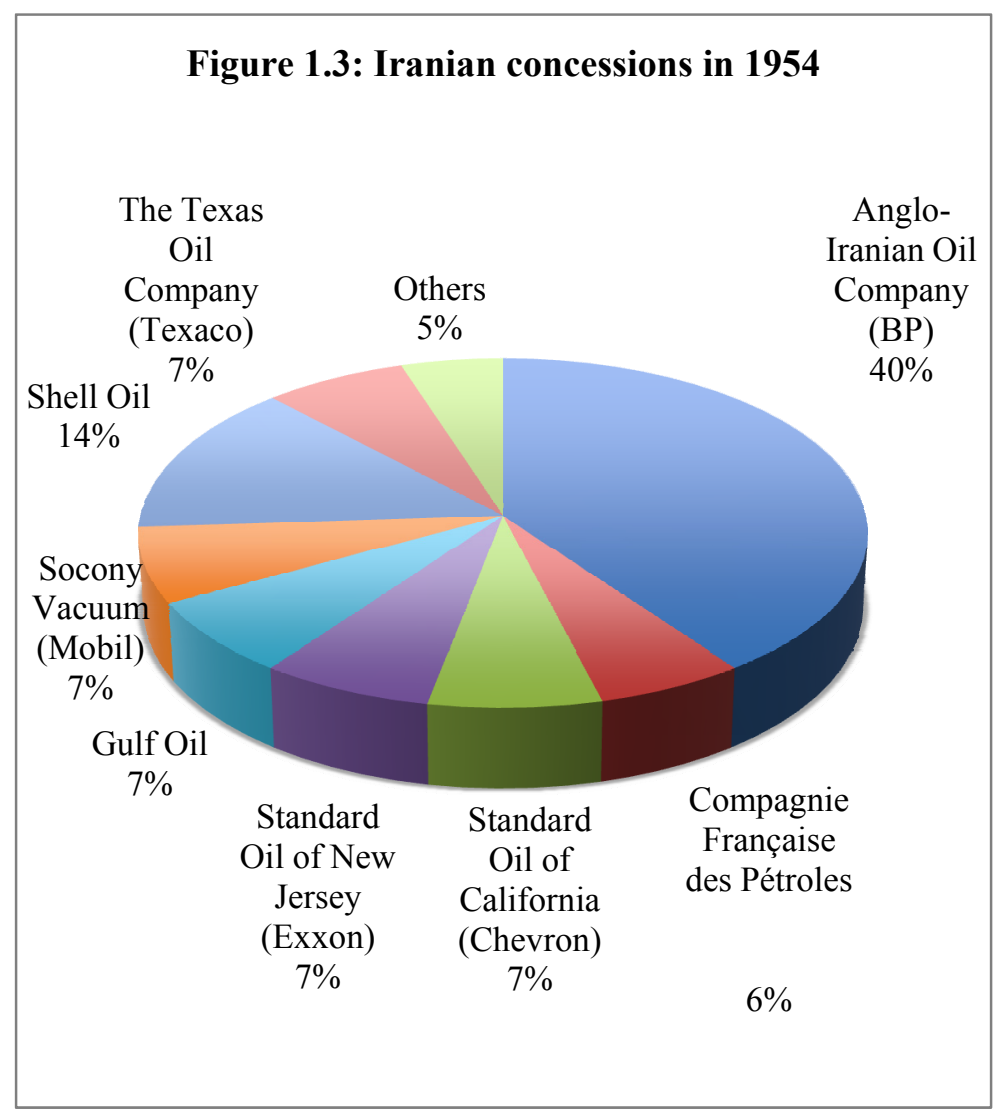

After the
coup, the British essentially
lost the role they had in
influencing Iranian domestic
affairs. This was transferred
to the Americans, to the
point that even domestic
socio-economic issues
within Iran were now linked
to US Grand Strategy in the
Middle East, always
discussed with the Soviet

nemesis in the background. ${ }^{92}$

As the new government in Tehran formed, the Americans, being the instrumental party behind the coup, negotiated a new consortium in order to prevent a repetition within its own areas of interest. This witnessed Anglo-Iranian, now British Petroleum, lose $60 \%$ of its stake in Iranian crude, forced to share the rest with Royal Dutch-Shell, five US majors,

\footnotetext{
${ }^{92}$ Dispatch from American Embassy-Tehran to State Dept. re Iranian Government reforms, March 10, 1954 [NSC Staff Papers, OCB Central Files, Box 42, OCB 091 Iran (File \#1) (5)]
} 
and CFP. ${ }^{93}$ Another consequential ramification of Mossadegh's downfall, and the new consortium that was developed under American auspices was the legality of ownership of Iranian reserves. As Daniel Yergin has noted, though in other host countries, the concessionaries had the legal mandate over the host's country's reserves, in Iran, dominion over the its underground crude reserves was transferred back to the Iranian state. ${ }^{94}$ And though weak and highly dependent upon foreign powers, this gave the Pahlavi monarchy breathing room to carve out, in modest terms, some modicum of independence in its oil dealings with the West, of which would become an important factor in both the creation and development of OPEC.

This newfound maneuverability, however modest, let to another significant outcome from the coup against Mossadegh and the decline of British Petroleum in Iran. The post-Mossadegh consortium arrangements in Iran, in dividing the concessions amongst the major IOCs, allowed, for the first time, a small window for independent oil companies to access the country. Though insignificant in amount, this new dynamic had major long-term ramifications. The most important independent oil company at that time, although initially seen as a nuisance to the majors, only to evolve into being a threat to their cartelization of the global oil industry, was the Italian state-owned Ente Nazionale Idrocarburi (ENI), headed by the ambitious Enrico Mattei. In his search to secure new sources of supply for the Italian economy, Mattei's ENI sought to undercut the majors by offering far more favorable profit sharing conditions. After securing a small but significant 75/25 profit sharing arrangement with Egypt's Gamal Abdel Nasser, ENI

\footnotetext{
${ }^{93}$ Parra, Oil Politics, 30.

${ }^{94}$ Yergin, The Prize: The Epic Quest for Oil, Money, \& Power, 504.
} 
capitalized upon the consortium flux in Iran, and in 1957 signed a contractual agreement with the Shah that, as Leonardo Maugeri has stated, introduced a new oil formula that officially broke the 50/50 profit sharing precedent, but more importantly created the next template for the continuation of the domino cascade that would eventually affect the relationships between other firms and producing countries. ${ }^{95}$ Under the new terms, Iran would be entitled to $50 \%$ of ENI's gross profits in the form of a tax, and then divide the company's net profits by $50 \%$, which in turn, would render that $75 \%$ of profits would go to the Iranian government. ${ }^{96}$ Maugeri also details that under the contractual stipulations, the company would 'cover the initial costs of exploration' and 'only after oil was discovered would' the newly formed Iranian National Oil Company (NIOC) and ENI equally split the costs of exploration, and would dually manage SIRIP, the joint company

created by the agreement between NIOC and ENI. ${ }^{97}$ Thus, not only was the $50 / 50$ precedent now officially broken, it for the first time, brought in the host country via the newfangled concept of the national oil company, in joint administration of oil production. ENI's move would soon create another remaking of the nature of the oil industry, ending one chapter, while beginning another.

\section{The Birth of OPEC}

Just as the development of the concessionary arrangements within the home-IOC-host nexus was not just attributable to market forces, but had consequential geopolitical and domestic political determinants behind them, OPEC's formation and the early years of its

\footnotetext{
${ }^{95}$ Maugeri, The Age of Oil: The Mythology, History, and Future of the World's Most Controversial Resource, 89-90.

${ }^{96}$ Ibid., 90.

${ }^{97}$ Ibid.
} 
institutionalization was also a product of the confluence of these factors. Within this Embryonic phase of OPEC's institutional life, the beginnings of the creation of the determinants behind what ultimately OPEC behavior is predicated upon began to emerge.

It was at the market forces, intrastate, and then outside actor influence levels (in that order) that, taken together, created the context, rationale, and space for OPEC's formation. The convergence of these three factors ultimately produced a unity of purpose amongst member states, facilitating inter-member dialogue wherein bilateral or multilateral issues at the interstate level (i.e. political differences, regional rivalries, etc.) did not impede cooperation and collaboration in the Organization's creation. This genesis can be traced to the alignment of three major trends within the international system that correspond to the three determinant levels at work in this Embryonic period: 1.) the changing nature of the global oil industry, particularly the supply and demand dynamics and oil pricing within the global economy at that particular time 2.) the unique economic and security dynamics within OPEC member states in the immediate years before and after the Organization's founding; 3.) the beginnings of the breakdown of the home-IOChost nexus and the willingness or incapability of major powers to halt that trend. As will be explained, the new dynamics at work at the macro level in the global oil market, forced the major IOCs to continuously lessen prices and manipulate exports in order to retain their market shares. However, in doing so, the major IOCs brought about substantial economic hardships on host producing countries, which at that particular time were facing both unprecedented economic and security challenges that could not tolerate a diminution in their oil income. 
Compounding the new changes in the global oil market and internal dynamics of proto-OPEC states was the American-Soviet Cold War, which led to the divergence of US geopolitical interests with that of the major IOCs, ultimately sundering the homeIOC-host nexus. This created the groundwork and the opening for the collusion of producing countries, which led to the formation of OPEC, culminating in the Organization's collective nationalization declaration in 1968, and ultimately the disintegration of the concessionary system that defined the global oil industry since its inception.

\section{Market forces}

\section{The immediate pre-OPEC global oil dynamics}

By the 1950 's, $85 \%$ of the global oil industry outside the US, Canada, the USSR, and China - from dominion over the reserves, extraction and refining to the mid-stream activities such as transportation, to marketing and selling at the consumer level - were controlled by the major international oil companies that eventually became known as the Seven Sisters, ${ }^{98}$ in addition to the French CFP. ${ }^{99}$ While the earlier discussed 50/50 arrangement between the host governments and IOCs, with often times the IOCs' home governments acting as backers of their firms' interests, caused a sea change in the

\footnotetext{
${ }^{98}$ The Seven Sisters was a term coined by Enrico Mattei, the first head of the Italian ENI, which consistently had some government ownership by the Italian government. The label was meant to highlight the dominance of the Anglo-Iranian Oil Company (modern day BP); Gulf Oil, Standard Oil of California (SoCal), Texaco (now Chevron), Royal Dutch Shell, Standard Oil of New Jersey (Esso), Standard Oil Company of New York (Socony) - (the latter two now ExxonMobil) on the global oil industry. See: Sampson, The Seven Sisters: The Great Oil Companies and the World They Shaped.

${ }^{99}$ See: Bassam Fattouh, "The Origins and Evolution of the Current International Oil Pricing System: A Critical Assessment " in Oil in the 21st Century: Issues, Challenges and Opportunities, ed. Robert Mabro and (Published by the Oxford University Press for the Organization of the Petroleum Exporting Countries, 2006). p. 43. \& United States. Congress. Senate. Select Committee on Small Business, The International Petroleum Cartel (Reprint); Staff Report to the Federal Trade Commission Submitted to the Subcommitteeon Monopoly Of ... August 22, 1952. [Reprinted] April 1975 (1975).
} 
functionality of the oil industry, it eventually established a normative principal of operation that lasted well into the early years of OPEC. The success of the 50/50 arrangement, measured by its longevity, had many factors, but a critical component of its durability was the skill of the major IOCs (i.e. the Seven Sisters and CFP) to hold together their integrated cartel over the global oil industry, primarily by controlling prices and crude oil output into the global economy. However, it was this proclivity from the major IOCs to continuously maintain their dominance over the market, that ultimately engendered a new cycle in the prior mentioned "domino cascade", which eventually forced the disparate host producing countries into collusion, ultimately ending the 50/50 paradigm and engendering the collective nationalization declaration by the incipient OPEC. The seeds of this new "domino cascade" can be found in the immediate postWWII economic environment.

The same cycle that appeared in the immediate years before WWI, which produced the oil scramble in the inter-war years, only to witness new sources of supply and increased output enter the market, was replayed in the aftermath of WWII. ${ }^{100}$ Aggravating the supply fears from WWII was the individual privatization of transportation in developed countries, as middle class consumers at the individual level, for the first time, in Western European countries, Japan, Canada, and more consequentially, the United States, obtained the means to possess automobiles. In response to the growing consumer demand at the individual level, not just the war-time and immediate post-war concerns of the great powers, the major IOCs significantly enhanced their profiles in the Middle East and Latin America, and began expanding oil

${ }^{100}$ Yergin, The Prize: The Epic Quest for Oil, Money, \& Power, 409-30. 
output from their respective concessions. And just as had happened in the inter-war period, with time, increased supplies relieved anxieties, ultimately leading to a market surplus, which facilitated and even encouraged the rise of the personal ownership of the individual's means of transportation.

However, a side effect of this same cycle that transpired in both World Wars and their aftermaths was a new constellation of forces that threatened the market-shares of the major IOCs like never before. In the first instance during WWI and its immediate aftermath, this was either not as apparent or definitely not as decisive. The new threat to the major's dominance came simultaneously from two sources: the rise of the independent, small firms that for the first time had the tangible ability to access reserves outside the major's control; and the growing production from the Soviet Union, only to be exacerbated by new discoveries in the Soviet bloc. A particular fear of the major IOCs was the merging of these two disparate forces, meaning the potential collusion of independent firms with accessible, cheap Soviet crude - a reality that was slowly beginning to take shape. The major's, however, recognized how this new constellation of new players and new supplies (and even new host countries) could severally erode their market dominance, if not decisive action was taken. Therefore, their reaction was to manipulate the market in such a way as to drown out competition, by making it economically unattractive and even unfeasible for the independent firms to enter or sustain themselves in the market.

The majors were able to do this because of the peculiarities of how prices and global supply were calculated at that. As Bassam Fattouh has catalogued, the majors' control of the upstream, midstream, and downstream aspects of the global oil industry 
allowed them to manage the 'rate of supply of crude oil going into the market through joint ownership of companies' that operated in the host countries, which meant that the 'vertically and horizontally integrated industrial structure of the oil market' rendered the global crude trade 'to a large extent a question of inter-company exchange with no free market operating outside these companies' control.' 101 This dynamic obviated significant amounts of "loose crude" to be sold by third parties, ultimately being responsible for keeping, for so long, independents firms from breaking into the global crude market in any meaningful way. ${ }^{102}$ The ramifications of this meant that the "host governments did not participate in production or pricing of crude oil and acted only as competing sellers of licenses or oil concessions,' which in return, they would acquire 'a stream of income through royalties and income taxes ' of whatever the majors exported from their territories, at whatever price the majors sold their crude for. Yet while the majors were concerned with market share protection, they needed a formula to systemize this process, in order for the host governments to know how the remuneration for crude leaving their territories, based upon the majors' profits, was being calculated.

This system of how the majors sold oil in the global economy became known as the posted price - again having the binary purpose of cartel-esque protection policies while also providing the host governments a structure of how they would be compensated for their crude. As Robert Mabro has explained, the logic of the posted price was that it publicly conveyed what any entity would accept or offer for 'a barrel of crude oil or a

\footnotetext{
${ }^{101}$ Bassam Fattouh, "An Anatomy of the Crude Oil Pricing System," (The Oxford Institute for Energy Studies, January 2011), 14.

${ }^{102}$ See: Ibid. \& E.T. Penrose and P.R. Odell, The Large International Firm in Developing Countries: The International Petroleum Industry (Greenwood Press, 1976).
} 
tonne of petroleum products.' ${ }^{103}$ As the majors controlled most of the infrastructure of the global oil industry, the prices they set became the standard on how oil was traded. And as Mabro has pointed out, because the host governments did not control any significant lever of the oil industry, but were mere bystanders to the IOCs operating in their territory, they gradually understood that the posted price matrix, in which they would receive a tax from the profit of what the IOCs made from the extraction, shipment, and sell of their crude, left no other formulation, 'such as spot prices or long-term contract prices...suitable for the purpose of tax computations. ${ }^{104}$ In other words, the oil export revenues that the host governments, to varying degrees, so depended upon were at the whim of whatever posted price the major IOCs set. Thus, when the majors witnessed the formation of the independent firms, with the steady rise of cheap Soviet oil, potentially threatening their market dominance, the market manipulation policies of lowering the posted price in order to undercut new competition had, with time, severe and lasting consequences for the host governments, as the latter witnessed the steady decline of a major portion of their national revenues. Nevertheless, while the host governments were certainly used to the vicissitudes of the majors' export and pricing policies in order to maintain the integrity of their global cartel, the period immediately before and after the formation of OPEC proved to be quite unique, eliciting markedly different reactions from the host governments and the major powers, most consequentially the US.

\footnotetext{
${ }^{103}$ Robert Mabro, "The International Oil Price Regime: Origins, Rationale and Assessment," The Journal of Energy Literature XI, no. 1 (June 2005): 3-5.

${ }^{104}$ See: Ibid. \&_— , "On Oil Price Concepts," (Oxford Institute for Energy Studies, 1984).
} 


\section{Intrastate dynamics}

The Internal Picture of the main proto-OPEC member states

Though each proto-OPEC economy differed from one another, possessing varying strengths and vulnerabilities, all of them heavily depended upon the revenue that they received from the taxes of their oil exports. In the immediate pre-OPEC environment, however, the gradual decline in revenues, by reason of the majors' market manipulation policies, exacerbated a dangerous economic, political, social, and security reality within the host countries. For reasons ranging from severe national security concerns from foreign threats, in that additional spending on military hardware was warranted, to economic difficulties due to demographic changes, to political upheavals from domestic oppositional forces, many of the host governments, simultaneously, found themselves in alarming to dire economic circumstances - all of which was happening in the beginning stages of the US-Soviet Cold War.

In Iran, the massive political and economic instability resulting from the coAmerican/British embargo of the country, by reason of Prime Minister Mohammad Mossadegh's oil nationalization efforts, and the latter's downfall in 1953, was still reverberating throughout the country. Though the US-backed Pahlavi dynasty's dominance was renewed after the coup, as a result of the American and British intervention in his favor, the economic deterioration in post-embargo Iran only added to the simmering political crisis in the country that never faded by Mossadegh's ouster. Due to Iran's long border with the Soviet Union and fearing Soviet influence over Iranian 
domestic affairs, ${ }^{105}$ the US apprehension about Iranian internal dynamics forced it to undergo a thorough review of its assessment of Iran's economy and its political dynamics. In a report by the US National Security Council, which was completed only a year after OPEC's founding, but was brought to the forefront in the wake of the demise of Prime Minister Jafar Sharif-Emami's first term (the fourth prime minister after Mossadegh), the American diagnosis of Iran's economic and political realities was quite grim:

The continuing trend toward revolution and chaos in Iran has reached the point where the US must take vigorous action. At the present time our position in Iran depends upon a regime that is pro-West but fragile and increasingly vulnerable to opposition pressures, most of them neutralists 106. There is a growing chance of domestic strike leading to chaos, or coups by rightist or leftist cliques, or Soviet-managed subversion. Any of these would probably lead, not to a hard neutralism with which the United States could live, but to such weakness and division as to make Iran incapable of withstanding Soviet pressures. It is this imminent possibility, rather than possible Soviet or Soviet-supported aggression, which is the greatest threat to US interest in Iran. ${ }^{107}$

The task force went onto recommend that the US use financial and military aid, along with political support at the domestic and international level to back the new Prime Minister Ali Amini and promote efforts at economic liberalization, infrastructure modernization, and the gradual political reform of the Shah's system. ${ }^{108}$ However, as the uncertainty in Iran continued, only to be exacerbated by a scheduled end of US aid to Iran, which had been planned months prior, Amini's continuance as Prime Minister became

\footnotetext{
${ }^{105}$ Whitman File, Dulles-Herter Series, September 1959. Secret. On the Department of State copy of this memorandum Mouser is the drafter and Henderson and Kohler concurred. (Department of State, Conference Files: Lot 64 D 560, CF 1471). Eisenhower Library.

${ }^{106}$ A common Cold War term for political actors that were neither pro-US nor pro-Soviet.

${ }^{107}$ National Security Council, 15 May, 1961, folder "Iran: General, 15 May 1961," document "A Review of Problems in Iran and Recommendations for the National Security Council," 2. Papers of John F. Kennedy. Presidential Papers. National Security Files. (\#3), Box 115, John F. Kennedy Presidential Library.

${ }^{108}$ Ibid.
} 
politically untenable, and in similar fashion to his predecessors, abruptly resigned. As Amini's possible resignation was a principal fear of the earlier mentioned NSC study, his abrogation of the prime ministership severally affected Washington's calculus towards Iran and the wider region.

In August of 1961, in an earlier version of second track diplomacy, Time Magazine's C.D. Jackson secured a secret interview with the Shah of Iran and reported his findings back to the US government. In his report, Jackson makes several references to the scheduled end of US aid to Iran, which after the 1953 coup against Mossadegh had markedly increased in both military and economic terms, particularly in the late 1950s. ${ }^{109}$ Within the interview, the Shah explained his country's financial difficulties to Jackson in rather candid form. According to Jackson, Iran's economy, at the dawn of OPEC's founding, broke down into three sectors: "the military sector; the national improvement or national plan sector, which [was] largely financed by the oil revenues; and the normal running of the government, which is where [the Shah depended] heavily upon grants in aid." ${ }^{110}$ Furthermore, the Shah conveyed to Jackson how Iran's economic difficulties were affecting its defensive military abilities in countering Soviet threats against the country. ${ }^{111}$ In other words, with the decline in the posted price in tandem with reduced aid from the West, Iran's domestic political and economic climate had severally worsened, only to be aggravated by Soviet fears, which pushed the Iranian government to

\footnotetext{
${ }^{109}$ For US aid figures to Iran, see the USAID database: $\underline{\text { http://gbk.eads.usaidallnet.gov/data/detailed.html }}$

${ }^{110}$ C.D. Jackson, 7 August, 1961, “Overseas Report (Confidential) \#5, folder "Iran: General, 1961-1963,” Box 119, Papers of John F. Kennedy. Presidential Papers. President's Office Files. John F. Kennedy Presidential Library.

${ }^{111}$ Ibid.
} 
divert dwindling resources for development and government funding towards military expenditures, which only perpetuated the internal crisis.

In neighboring Iraq, the domestic scene in the country resulting from the downward pressure on oil prices and the effects on the government's revenues was severally intensified by the political upheaval and later fallout from the July Revolution of 1958, which wiped out the entire infrastructure of the Iraqi monarchy from the political scene, only to set up a fragile republic under the stewardship of General Abdul Karim Qassim. With the demise of the US-friendly Hashemite dynasty in Iraq, the US assessment of Qassim's hold on power, seen through the Cold War prism, was mixed, yet one of foreboding:

the Communists in Iraq with Soviet advice and assistance have reached a serious position of strength. Qassim...has shown no inclination to move against the Communists. His open reliance upon Communist support strongly suggests either (1) that he is the dupe or willing tool of the Communists or (2) that he is fearful that he will be forced to share or ultimately relinquish power if he calls upon the army and/or other nationalist elements for help in suppressing the Communists... even assuming he is not a Communist or dupe of the Communists, we see little prospect of Qassim's moving effectively to stem the growth of Communist strength.

As a result, the US and other Western power's assessment of their influence in postmonarchial Iraq was that it was quite limited, as any overt intervention would possibly invite a more robust Soviet presence, with unforeseen consequences. ${ }^{113}$ Moreover, the meteoric rise of Egypt's Gamal Abdel Nasser, particularly the Egyptian union with Syria,

\footnotetext{
${ }^{112}$ Department of State, S/S-NSC Files: Lot 63 D 351, NSC 5820 Memoranda. Top Secret. Drafted by Lakeland.

${ }^{113}$ See Recommendations section in: Files of the Special Assistant for National Security Affairs, Near East. Top Secret. Drafted by Rockwell. Sent by Calhoun to Karl G. Harr, Jr., at the White House for use at the April 17 meeting of the NSC. Eisenhower Library.
} 
in the form of the United Arab Republic (UAR) in 1958, dramatically escalated fears in Washington on the possibility of the UAR's intervention in an unstable Iraq. ${ }^{114}$ Thus, unlike the rise of Mossadegh in Iran, because of what many feared was Soviet penetrative contagion in addition to enticements of Pan-Arabism directed towards Arab states, the US and Western powers took a very nuanced position towards Iraq, with what the US termed as 'maximum degree of flexibility'. 115

Across the Persian Gulf, the intersection between declining posted price and the concerns of the Saudi state were far less apparent, but equally as consequential. Unlike Iran, Saudi Arabia was not recovering from a systemic boycott of its oil exports and dissimilar to Iraq, which was suffering from massive political instability as a result of revolution. Yet, like Iran and Iraq, its regional security concerns had major economic ramifications on its domestic budget - of which the declining posted price only brought additional hardship on the coffers of the Saudi state. Not only had the revolution in Iraq escalated Saudi concerns, but as was the case in the region and amongst Western powers, the penchant for agitation by Nasser's UAR, significantly worsened fears in the House of Saud. For a conservative monarchy, the elevation of Nasser's authoritarian republicanism, rooted in the concept of Pan-Arabism which fundamentally rejected the concept of the Arab client regime backed by Western powers for the latter's strategic concerns, directly threatened not only Saudi influence on Arab affairs, but also gradually challenged the House of Saud's domestic standing. Though this newfound fear of Nasser's Pan-Arabism

\footnotetext{
${ }^{114}$ Special National Intelligence Estimate, 28 April 1959, Department of State, OCB Files: Lot 61 D 385, Iraq Documents. Secret.

${ }^{115}$ Memorandum From the Assistant Secretary of State for Near Eastern and South Asian Affairs (Roundtree) to Acting Secretary of State Dillon, 22 December 1958, Department of State, S/S-NSC Files: Lot 63 D 351, NSC 5820 Memoranda. Top Secret. Drafted by Lakeland.
} 
drove the Saudis to divert more money into defense spending, it was the Yemen crisis of the late 1950s, and the eventual disintegration and civil war in North Yemen that caused mass alarm in Kingdom. ${ }^{116}$

Taken together with the new form of government in Iraq, the rhetorical challenge from Cairo and Damascus, and the rapid deterioration of security on the Saudi-Yemeni frontier, the House of Saud witnessed a revolutionary Pan-Arab, republican encirclement of their strategic environment, partly backed by Soviet political and military might.

Though markedly different in nature and scope, the same mixture of internal economic disarray, political instability, declining oil revenues, regional flux, and the fears of Soviet penetration were also present within the Venezuelan milieu. Being democratically elected to his second term as President, after his exile from the country during the dictatorship of Marcos Pérez Jiménez, Rómulo Betancourt inherited similar domestic dynamics of political and economic disorder resulting from the downfall of the prior regime, while also witnessing the same pattern of Soviet-sympathetic regional flux centered in the new Castro regime in Cuba. Because of the deterioration of US-Cuban relations after the Cuban revolution, and fearing Soviet political and military infiltration near American borders due to the creation of an avowedly pro-Soviet government in Cuba, the US not only attempted to confront the rise and strength of the Castro regime, but also to contain Cuban and Soviet influence within Central and Latin America. For this, they initiated a similar reassessment of the region, in similar fashion to what had simultaneously been transpiring in US policy in the Middle East. Only months after the

\footnotetext{
116 Memorandum from William H. Brubeck to McGeorge Bundy, 4 October 1962, folder " Saudi Arabia: 1961-1963” Box 119, Papers of John F. Kennedy. Presidential Papers. President's Office Files. John F. Kennedy Presidential Library.
} 
unsuccessful Bay of Pigs operation, launched to unseat Castro, the US, in its National Intelligence Estimate of November of 1961, painted a bleak picture of what the Betancourt government and Venezuela faced in the near future:

The Betancourt administration ...is opposed by extreme leftists, including the Communists and other Castro sympathizers, and also by rightist elements, but with the support of the armed forces, has survived repeated coup attempts, including several attempts to assassinate Betancourt. Despite the resources available to it, the Betancourt government is beset by severe financial problems resulting from (a) the end of the Venezuelan oil boom with a consequent decline in the growth of income from the petroleum industry, and (b) greatly increased expenditures for politically necessary social welfare programs. Its difficulties have been further complicated by a serious economic recession and heavy flight of capital...Popular dissatisfaction and impatience with the slow rate of economic improvement is likely to grow, especially in the congested urban areas. This dissatisfaction will provide the Communists and other revolutionary leftists with further opportunities for agitation against the regime. At the same time, distrust and dissatisfaction in business circles is likely to continue, and some rightists will continue to conspire with reactionary military elements to overthrow the regime. Thus Betancourt will remain under continuing threat from both the left and the right. ${ }^{117}$

Furthermore, Venezuela's economic disorder had only recently worsened as a result of American oil import quotas, placed during the end of the Eisenhower administration to buttress support for US oil firms, also for the benefit of America's immediate neighbors, Canada and Mexico. In this environment, while Betancourt's political rule was not deemed to be existentially threatened, the myriad of difficulties he faced, most notably capital flight, ${ }^{118}$ was feared to cause paralysis and obstruction in effective governance,

\footnotetext{
${ }^{117}$ National Intelligence Estimate No. 89-61, 21 November 1961. "The Situation in Venezuela." Secret. 3 pp. CIA Files: Job 79-R01012A, ODDI Registry.

${ }^{118}$ Memorandum of conversation, February 20, 1963, between President Kennedy and President Bentancourt and other U.S. and Venezuelan officials. Flight of capital from Venezuela. Confidential. 2 pp. Kennedy Library, National Security Files, Countries Series, Venezuela, March-May 1963.
} 
while also limiting his chance to construct any effective post-revolutionary stability for his successor and the country writ large. ${ }^{119}$

Yet, by far, the producing country that would become an OPEC member only two years after the establishment of the Organization, which faced the most dire economic, political, and security threats was Indonesia. Though not a founding member and not instrumental in the creation of OPEC, Indonesia's importance as a battleground state within the wider Cold War went beyond its oil production. The country's proximity to vital shipping lanes for the global economy only added to the natural significance it had as being an oil producer. But in the wake of the country's hard fought independence against the Netherlands in 1949, the country's newfound sovereignty could not be secured as parts of the country was ravaged from the independence war, while key sectors of its economy was still reliant upon the Dutch, with little indigenous manufacturing capability, mass societal poverty, ethnic tensions, and an uncertain political future. From the US standpoint, these issues were well known, not only because the US was instrumental in brokering the peace negotiations between the Netherlands and Indonesia, but due to, as in the aforementioned producing states, the threat of communist infiltration. This was clearly spelled out in the US National Security Council Report on its policy towards Indonesia in 1955, explicitly stating that the 'loss of Indonesia to Communist control would have serious consequences for the US and the rest of the free world. ${ }^{120}$ As the country was reeling from economic calamity after its war with the

\footnotetext{
${ }^{119}$ Ibid.

${ }^{120}$ Department of State, S/S-NSC Files: Lot 63 D 351, NSC 5518 Series. Top Secret. Transmitted under cover of a note from NSC Executive Secretary Lay stating that the enclosed draft statement of policy was transmitted for consideration by the Council at its May 12 meeting and that it was intended, if adopted, to supersede NSC 171/1.
} 
Dutch, it reached out for aid to whomever would provide it, and thus, among the several political, cultural, and security assistance that the US was contemplating providing Indonesia, was assisting the country in 'meeting its important economic problems and in countering attempted Communist economic penetration'. ${ }^{121}$

Amongst the many policies that the US was to pursue, the infusion of direct American aid became a staple of its policy towards Indonesia. Furthermore, during this period, the US treated the country's political elite with kid gloves, as the dire economic situation in the country, was only made worse by growing ethnic tensions that America feared would lead towards the disintegration of the newly formed state. ${ }^{122}$ Thus, when Indonesia, in the late 1950s, began expropriating critical infrastructure in the country from the Dutch, including oil infrastructure, and thus partially nationalizing them, the US reaction was very subdued due to the fear of Soviet exploitation of Indonesian anger against what the latter would feel was an antagonistic US position. And even in the face of an Indonesian administration that often was quite critical of the West, because of its history with colonialism, and had political parties in government that were openly sympathetic with the Soviet position, the US gradually began to provide Indonesia with modest military aid as well. ${ }^{123}$

From Iran, to Iraq, to Saudi Arabia, to Venezuela, to Indonesia, the summation of acute economic, political, and security peril and uncertainty in these disparate countries,

\footnotetext{
${ }^{121}$ Ibid.

${ }^{122}$ Department of State, Central Files, 756D.00/5-1757. Secret. Sent through Howard P. Jones, who initialed the memorandum and sent it to Robertson.

${ }^{123}$ Department of State, Central Files, 756D.5-MSP/11-1257. Secret. Sent through Howard Jones who initialed. Also sent to Under Secretary Herter with a covering memorandum of November 15 from Robertson, suggesting that he arrange a conference with Deputy Secretary of Defense Donald A. Quarles and Allen Dulles to make a final decision on Indonesia's request.
} 
ultimately created the conditions where more budgetary liquidity was needed by the host countries. This ultimately would become the catalyst for effective collusion amongst the significant oil producing countries.

\section{The Host Countries Act}

\section{From Collusion to Creating OPEC}

The simultaneous economic and political dynamics within the major oil producing countries of that would eventually become OPEC Members caused a systemic reassessment to how great powers in the free market economies, most consequentially the US, viewed the relationship amongst host governments, major IOCs, and themselves. In 1960, the four countries of Iran, Iraq, Kuwait, and Saudi Arabia accounted for approximately $33 \%$ of global oil production ${ }^{124}$ and synchronous instability within them, and the economic and security ramifications for the international system would have ranged from the severe to the catastrophic, especially if other important producers in the Middle East, such as Kuwait, also became unstable. This reassessment, primarily centered in the US, which had become the leader of the free market economies, due to the decline of European power after WWII, gradually created the rift in the strategic interests of the great powers with the major IOCs. While the latter were solely concerned about market share protection and constantly on guard at attempts by nationalist governments to appropriate the oil industry in producing host countries, the US, now the sole guarantor of the home-IOC-host nexus, had gradually developed other concerns.

The economic deterioration in many proto-OPEC states was not only viewed as a threat to free market economies, but also a grave security concern in the Cold War rivalry

${ }^{124}$ See: http://www.opec.org/opec_web/en/data_graphs/40.htm (accessed June 10, 2012) 
with the USSR. Thus, while the major IOCs could in the past count on some type of general home government support, of which the US was the linchpin, to aid and assist their foreign operations, mainly because of supply access and market stability, the geopolitical contest between America and the Soviet Union and concurrent events in several producer states had now changed the formula wherein US policy was devised and implemented.

The US policy of 'maximum flexibility' towards the fallout of the 1958 Iraqi Revolution gradually expanded to oil producing countries in general. The host countries, though weak individually, understood the latent power of the "domino cascade" in the oil industry, especially in light of the 50/50 precedent. Moreover, they implicitly understood that regardless of the differences between them, and in the case of Venezuela and Middle Eastern producers, the vast distance, their respective interests as it related to greater control over their oil exports and remuneration was more readily achieved by collusion and unity. Under Betancourt, and partly as a reaction to the US import quotas, Venezuela, having never surrendered its 'legislative prerogatives on taxation' increased the government revenue from all of the country's oil industry to close to ' $70 \%$ of net profits'. 125 The Middle Eastern producers immediately took notice, and due to Venezuela's preeminent position in the global oil industry at that time, in that the country was the world's third largest crude producer, ${ }^{126}$ the possibility of a renegotiation of the $50 / 50$ arrangement now seemed possible.

\footnotetext{
${ }^{125}$ Parra, Oil Politics: A Modern History of Petroleum, 89-90.

${ }^{126}$ See: http://www.opec.org/opec_web/en/data_graphs/40.htm (accessed June 10, 2012)
} 
A year after Venezuela's new agitation, in 1959, the important producing countries of the Arab world, with the addition of Iran and Venezuela, met in Cairo and held what was dubbed the First Arab Petroleum Congress, which essentially was a meeting of the minds of host countries in hopes of finding a way to collectively revisit the 50/50 arrangement that was no longer able to satisfy their domestic budgetary needs. ${ }^{127}$ On the sidelines of that meeting, under Venezuelan insistence and initiative, representatives of the five major host producing countries of the world - Iran, Iraq, Saudi Arabia, Venezuela, and Kuwait - came to an understanding to systemically collaborate with each other in order to change the contours of the profit sharing between the IOCs and the hosts. ${ }^{128}$ Yet, though they signed what was to become the MAADI Pact to facilitate collaboration amongst themselves, as the months dragged on, very little, if any came of the meeting. There was a simple explanation for this. Alirio Parra, a close assistant to Venezuelan Energy Minister, Juan Pablo Pérez Alfonso, one of the signatories of the MAADI Pact (who was both instrumental in the early collaborations between producing countries and is considered as one of the Founding Fathers of OPEC), has stated that Pérez was the only official with his government's backing and authority when that document was signed. ${ }^{129}$ According to Parra, it was only after the major IOCs in August of 1960, further reduced the posted price, which only worsened the budgetary constraints of producing countries that the spirit of the MAADI Pact started to come to

\footnotetext{
${ }^{127}$ See: Harley C. Stevens, "Some Reflections on the First Arab Petroleum Congress," Middle East Journal 13, no. 3 (1959): 273-80. \& Arabian American Oil Company, First Arab Petroleum Congress, Cairo, Uar, 16-23 April 1959 (Arabian American Oil Company, 1959).

${ }^{128}$ Parra, Oil Politics: A Modern History of Petroleum, 93-98.

${ }^{129}$ The Organization of Petroleum Exporting Countries, in OPEC Bulletin: Golden Jubilee Edition (Vienna, Austria: The Organization of Petroleum Exporting Countries September 2010), 44-51.
} 
fruition. ${ }^{130}$ If anything, though the Pact was only a gentleman's agreement in the months after it was signed, it did provide clarity to producing countries on the need for collusion, and the simultaneous willingness to do so. In Iraq, the economic pressures on Abdul Karim Qassim's new Republican regime had already forced it to individually challenge the 50/50 arrangement with the concession holders of the Iraqi Petroleum Company (IPC). ${ }^{131}$ Though Qassim was able to enlarge Iraq's profit shares to $60 \%$, the fundamental problem for Iraq and the other hosts was not just the percentage of profits but also prices and the volume of exports, which was totally in the domain of the IOCs control. Immediately after the August 1960 posted price reduction by the IOCs, Qassim's regime, already in heated negotiations with the IPC concession holders, decided to capitalize on the renewed sense of frustration amongst the host countries, and invited them to Baghdad, in hopes of empowering the earlier MAADI Pact into something tangible. Qassim's invitation was particularly striking as the new Iraqi Republican regime was extremely suspicious of Iran and had earlier made territorial claims on Iran's Khuzestan province and the whole of Kuwait. Yet, for the sake of expediency, Qassim's Iraq understood that no effective, lasting cooperation between the producing countries could be achieved without active Iranian and Kuwaiti participation.

A month after the IOCs further reduced the posted price, in September of 1960, the 5 top host producing countries - Venezuela, Iran, Iraq, Saudi Arabia, and Kuwait met in Baghdad in hopes of formalizing a collaboration that would halt, and possibly reverse the declining posted price. As the representatives initiated what was to become an

\footnotetext{
${ }^{130} \mathrm{Ibid}$

${ }^{131}$ A. Dawisha, Iraq: A Political History from Independence to Occupation (Princeton University Press, 2009), 182.
} 
intense dialogue, the formalization behind their collusion went further than simply an outcry by a collection of weak developing host countries. In OPEC's first two Resolutions, I.1 and I.2, of which Fuad Rouhani, OPEC's first Secretary General, has labeled the 'embodiment' of the Organization's 'constitution or charter', ${ }^{132}$ the Members laid out not only their principle complaints of the profit sharing arrangement that was fundamentally rooted in the concession system, but more so, what their primary intentions were in regards to the future of production. Resolutions I.1 and I.2 had four basic principles that once again altered the nature of the relations between producing countries and large, technologically advanced oil companies, but more so revolutionized the nature of the oil industry as a whole. ${ }^{133}$ Firstly, the resolutions drew the direct linkage from IOC behavior to the internal economic and security conditions within OPEC Member states, in that it specifically stated that Members were simultaneously 'implementing much needed development programs' 'financed mainly from income derived from their petroleum exports' and thus 'must rely on petroleum income to a large degree in order to balance their annual national budgets'. ${ }^{134}$ The Members further stated that that 'any fluctuation in the price of petroleum necessarily affects the implementation of the Member's programs and results in dislocation detrimental not only to their own economies, but also to those of all consuming nations.' ${ }^{135}$ Secondly, the resolutions, for the first time in the history of the petroleum industry, announced a formal

\footnotetext{
${ }^{132}$ F. Rouhani, A History of O.P.E.C (Praeger, 1971), 75-78.

133 OPEC, Opec Official Resolutions and Press Releases 1960-1990 (The Secretariat, Organization of the Petroleum Exporting Countries, 1990), 1-2.

${ }^{134}$ Ibid.

${ }^{135}$ Ibid., 1.
} 
declaration of Inter-state policy formulation and regulation of production by host countries. For years, the IOCs dealt with individual host countries separately, dividing them amongst themselves, playing one off against another, and severally impeding collective host state cooperation. Third, the resolutions explicitly sketched out a policy of economic protection for all Members in the face of possible IOC sanctioning a particular Member. The Members unambiguously stated that if such an event occurred against one Member state, the other Members would resist efforts to increase production at the detriment of the Member being sanctioned. And finally, the 5 Members of OPEC formally announced plans to increase membership with a clause that was tantamount to an open invitation to other producing states. With these four aims, the 'principle aim' of the nascent OPEC became clear: 'the unification of petroleum policies for the Member Countries and the determination of the best means for safeguarding the interests of Member Countries, individually and collectively.' 136

\section{Outside Actors}

\section{The US policy of 'Conscious Indifference'; the fall of the Home-IOC-Host Nexus}

The news of formalized collusion amongst the 5 major host producers caused varying reactions amongst the home governments of the IOCs and the IOCs themselves, the former being dismissive while the latter being bewildered and apprehensive. The US Embassy in Baghdad transmitted a perfunctory report of the events in mid-September of $1960,{ }^{137}$ and a week afterwards, at a meeting of the US National Security Council, President Eisenhower, in his last months in office, dismissed the importance of the

\footnotetext{
${ }^{136}$ Ibid., 1-2.

${ }^{137}$ Department of State, Central Files, 800.2553/9-1560. Unclassified. Repeated to Beirut, Cairo, Caracas, Dhahran, Jidda, Kuwait, London, and Tehran.
} 
formation in its entirety, claiming that 'anyone could break up the Organization by offering five cents more per barrel for the oil of one of the countries. ${ }^{138}$ Because the initial impetus behind the Baghdad meeting was the August reduction in the posted price by the IOCs, the US drew the conclusion that formalized cooperation between the hosts could be nipped in the bud by peeling off one by individualized pricing deals, in order to isolate the others, ultimately to split the Organization, rendering its potential for effectiveness null and void.

However, it was not until a few weeks after OPEC's creation where the reaction of the IOCs could be gauged. It was here where the signs of possible divergence of perception were seen between the US government and the IOCs. In meetings between the US State Department and certain IOCs on methods of dealing with Soviet oil export policies and the meaning of host state collusion under the newfangled OPEC umbrella, IOC executives were far more circumspect than the US government assessment. ${ }^{139}$ Leo Welch, chairman of the board at Standard Oil of New Jersey, stated that OPEC's formation and possible collusion on price and exports had far reaching negative ramifications for the oil industry, particularly for the IOCs. Specifically, Welch feared 'that the companies will be caught between producer country controls and the demands of consuming countries... [and that they] will no longer be able to manage their business in a normal way since the governments would take over the determination of oil prices, the

\footnotetext{
${ }^{138}$ Memorandum of Discussion at the $160^{\text {th }}$ Meeting of the National Security Council. Eisenhower Library, Whitman File, NSC Records. Top Secret. Drafted by Boggs on 21 September 1960.

${ }^{139}$ Department of State, Secretary's Memoranda of Conversation: Lot 64 D 199. Confidential. Drafted by Beckner and approved in Dillon's office by Special Assistant Theodore Eliot on 27 October 1960.
} 
amounts of oil to be produced, and the destination of oil shipments. ${ }^{140}$ Victor De Metz, chairman and director-general of Compagnie Française des Pétroles, expressed strong opposition to the groups formation for this very reason, due to the possibility that OPEC Member states would engage in the pro-rationing of output, ${ }^{141}$ the same market manipulation scheme that the major IOCs had depended upon to keep intact the integrity of their cartel.

Yet, this apprehension on the possibility of full cooperation was also coupled with the conventional IOC assessment of the then-current power of host countries. Prorationing was greatly feared, but according to the IOCs, simply not viable at that time. Welch went onto to attest that while 'OPEC has been set up in a preliminary form, ... it has basic weaknesses which will prevent the development and administration of a restriction program. ${ }^{142}$ These vulnerabilities had far more to do with not price, but more so with an integrated and collective output policy, in that OPEC Members had fundamentally differing assessments on how to integrate their oil output with the collective Organization's macro output. Welch speculated that 'Iran and Iraq would not be reliable members since they badly need increased output,' while the other Members were strictly concerned about an increase to their falling royalties. ${ }^{143} \mathrm{He}$ went onto subscribe to Eisenhower's policy of Member division early on, stating that the IOCs 'could work out arrangements with individual countries to meet their most pressing

\footnotetext{
${ }^{140}$ Ibid

${ }^{141}$ Department of State, Secretary's Memoranda of Conversation: Lot 64 D 199. Confidential. Drafted by Beckner and approved by Eliot on 9 November 1960.

${ }^{142}$ Department of State, Secretary's Memoranda of Conversation: Lot 64 D 199. Confidential. Drafted by Beckner and approved in Dillon's office by Special Assistant Theodore Eliot on 27 October 1960.

${ }^{143}$ Ibid
} 
problems. ${ }^{144}$ However, Standard Oil of New Jersey evinced increasing concern about the future enlargement of the Organization, particularly as it related to Libya. During his meeting with the State Department, Welch revealed that Jersey executives were now in Libya 'attempting to convince Libyan officials that they would have much to lose by joining OPEC', claiming that as a result of becoming a Member, Libya 'will have low cost oil favorably situated for the European market.' 145

Thus, IOCs recommended that the US government use its vast political influence to urge OPEC Members 'to go slowly in completing the OPEC organization and implementing its program', ${ }^{146}$ and as Harold Wilkinson, Managing Director of Shell exhorted, 'to convey to the appropriate governments concerned the thought that it would not be in their interest to unilaterally force private companies to act against their will. ${ }^{147}$ Yet, with this admonishment came also a threat. The IOC concession holders noted that in the event that they were forced to act against their economic interests in the host countries, not only could this affect 'the whole climate of private investment' ${ }^{148}$ but also could engender retaliatory measures from 'a bloc of powerful consuming countries' while the IOCs would be forced to set free new supplies from untapped oil reserves, hence further weakening OPEC Member states. ${ }^{149}$

\footnotetext{
${ }^{144}$ Ibid

${ }^{145}$ Ibid

${ }^{146} \mathrm{Ibid}$

${ }^{147}$ Department of State, Secretary's Memoranda of Conversation: Lot 64 D 199. Confidential. Drafted by Dillon on 3 November 1960.

${ }^{148}$ Ibid

${ }^{149}$ Department of State, Secretary's Memoranda of Conversation: Lot 64 D 199. Confidential. Drafted by Beckner and approved in Dillon's office by Special Assistant Theodore Eliot on 27 October 1960.
} 
However, as the US weighed its options, it quickly understood that its calculations, particularly in light of the emerging Cold War dynamics, were far more complicated than the IOCs assessment. Moreover, the lack of an effective Soviet response, for or against the creation of OPEC, caused even more confusion. Had the Members collusion simply played in the hand of the Soviets, there would have invariably been the same reaction from both IOCs and their host governments, as the Soviet Union was considered a detriment to the Western government's strategic interests, while the increasing Soviet oil in the global economy was accurately viewed as a threat to the market dominance of the IOCs. Yet, OPEC's creation have could have gone either way for the Soviet Union. The USSR could have hypothetically become a member of the newfangled Organization, as there would have been clear advantages for the Soviets to do so. Nevertheless, the latter could have equally have looked at OPEC as a rival to new markets, as the Soviet Union was looking to enhance its share of Europe's consuming market - an intention they announced at the Second Arab League Petroleum Congress in Beirut only a few weeks prior, in October of $1960 .{ }^{150}$ After all, it was the inclusion of new, Soviet oil in the market that caused the IOCs to continuously decrease the posted price, which is what was causing major damages to the economies of the host governments. Aggravating this was the fear of how economic and political calamity in the host countries, due to the lowering of the posted price, could lead to the downfall of various host governments, which, in the mind of many officials in the West, could easily lead to communist takeovers, and severally upgrade and enhance the strategic profile of the Soviet Union. As formalized

\footnotetext{
${ }^{150}$ Department of State, NEA Files: Lot 62 D 435, 21 November 1960 Chron. Confidential. Drafted by F.M. Dickman of NE/E.
} 
collaboration was happening at the international level, at the bilateral level, the US witnessed the governments of host countries, either directly or indirectly, ask for aid from Washington - all of which derived from the same economically based maladies, with subsequent security and political ramifications.

In late November of 1960, after weighing the viewpoints of some major IOCs, the Director of the Office of Near Eastern Affairs, Armen Meyer, conveyed a thorough review of OPEC's formation and the subsequent policy options that the US could reasonably pursue. Though Meyer conceded that the catalyst that triggered OPEC's creation was the major oil companies reducing Middle East posted prices for crude oil, and to possibly 'establish some form of joint pro-rationing,' the weaknesses within the Organization, in line with the IOC assessment, rendered this aim 'almost impossible to realize.' ${ }^{151}$ An underlying problem, according to the US perception, that plagued OPEC was that it did not have strength in numbers, particularly the absence of Libya and Algeria, not to mention other important producers. Meyer's report essentially dismissed the possibility of Libyan and Algerian integration into the Group, as both were 'preoccupied in becoming major oil producers,' meaning they needed private investment and could not afford to risk antagonizing the same sources of technology in terms of extraction and shipping, let alone the possessors of market access. ${ }^{152}$ Furthermore, though Meyer cautioned that it would be extremely difficult for the US to publicly criticize OPEC's future pro-rationing of oil when the US engages in the same practice domestically, the ability for OPEC Members to engage in such pro-rationing policies was

${ }^{151}$ Ibid
${ }^{152}$ Ibid 
not given, as there were 'many obstacles in the way of parceling out each country's share of the world's oil market unless all producer and consumer countries are members of the same organization.' ${ }^{153}$ Nevertheless, Meyer cautioned that based upon the economic and political uncertainty in OPEC Member states, along with the persistent mistrust concerning Soviet intention concerning OPEC Member state dynamics and their own oil export policies, US policy options were more limited and constrained than in past eras:

When the OPEC becomes a permanent functioning organization, the US will have three choices: (1) Support the organization. In the event the US should support OPEC, it would probably be necessary for us to revise existing antitrust laws to enable American oil companies to consult jointly when discussing prices with oil producing countries. It would also seem to violate our present policy that international commodity arrangements should allow for equal representation between consumer and producer countries. (2) Oppose OPEC. Should the US oppose the OPEC by pointing out its shortcomings (as suggested by several oil company representatives), it would undoubtedly antagonize the oil producing countries that have joined the organization. They would view this as unwarranted interference and as evidence that the US is working hand in glove with oil monopolies. It would probably strengthen OPEC and encourage member countries to take further measures to control the operations of the oil companies working in their respective countries. There is also the danger that the Soviet Union could exploit this antagonism. (3) Remain neutral. By not taking sides with regard to the OPEC, the US would be carrying out its existing policy of remaining in the background in matters affecting relations between oil companies and oil exporting nations and thus avoid intervening on behalf of American oil companies except in extreme cases involving questions of security of international law. This policy gives us the greatest flexibility and allows us to deal with petroleum matters on a case-by-case basis. ${ }^{154}$

Eventually, Meyer's third policy option became the leitmotif of how the US would react to Organization's formation, and later institutionalization. This policy of "conscious indifference" was further buttressed by the analysis contained within the US National

${ }^{153}$ Ibid

${ }^{154}$ Ibid 
Intelligence Estimate (NIE) of 1960, where this assessment evolved. Within the broad evaluation of Middle East, the NIE forecasted three major trends. The first concerned the inevitable collapse of the conventionalized profit sharing arrangement, in that the US foresaw that the 'Western oil companies will be further weakened by erosion of the 50/50 profit sharing formula and by the joint efforts of the producing countries to control prices.' ${ }^{155}$ The second trend concerned the fundamental incapability of OPEC Members, in the short term, to integrate a cooperative mechanism to fundamentally control prices and output - thus threatening major IOCs investment in their countries. The US assessment claimed that while 'greater participation by local governments in the management of the oil companies is likely', 'large-scale nationalization of industry facilities is [not] probable', hence 'companies will [not] feel compelled to liquidate their interests in the area during the period of this estimate'. ${ }^{156}$ US dismissiveness of OPEC was only partially due to the collective weakness of the Organization and the individual countries of the Group. The US also factored that, at least for the short-term, 'any effective joint action by the producing states', chiefly as it related to pro-rationing, would not take place, primarily 'because of mutual jealousy and suspicion because of competing economic interests', with the sole exception of the possibility of influencing the IOCs pricing arrangement. ${ }^{157}$ Nevertheless, the longer term forecast brought much nuance to the US position, chiefly concerning the future survivability of the concessionary system that the Seven Sisters created:

\footnotetext{
${ }^{155}$ Source: Department of State, 13 December 1960, OCB Files: Lot 61 D 385, Middle East Documents. Secret

${ }^{156}$ Ibid

${ }^{157}$ Ibid
} 
....as the government of the producing countries gain greater influence in the management of the oil industry, there will probably be a growing number of cases in which their policies and desires conflict with those of the Western governments.... Over the longer term, even broader problems are likely to emerge. The ultimate aim of some Middle Eastern officials and leaders is probably an arrangement whereby the present concessionary interests of the international oil companies in the area are eliminated and Western companies act at most only as agents of the producing countries. Such an arrangement would not necessarily preclude the supply of sufficient oil for Western Europe and of sufficient revenue for the Middle East. It might even alleviate certain political problems, which now confront the West in its relations with the producing countriesespecially those which stem from the close association in the Middle Eastern mind of the companies with Western governments. ${ }^{158}$

While the US understood that eventually the concessionary arrangements would be abolished, it did not view this possibility any longer as a threat to the interests of the West, let alone to US interests, so long as 'a surrender or large-scale withdrawal of Western company interests under pressure' which would be 'a setback for Western prestige', did not take place. ${ }^{159}$ Hence, the host countries gradual exaction of control over the price formulation in the short-term, and the measured appropriation of the entire oil industry in their countries in the long term, as long as it was not abrupt or humiliating, and did not create market instability, was a scenario that the US government, the principle power within the free market economies, could live with. And with the arrival of this consensus, the home-IOC-host state nexus began the gradual process of disintegration.

\footnotetext{
158 Ibid

${ }^{159}$ Ibid
} 


\section{CHAPTER II • THE INFANCY PHASE: THE INSTITUTIONALIZATION OF OPEC AND THE STRUGGLE FOR COLLECTIVE ACTION, 1961-1969}

The unique confluence of circumstances in the early 1960s created the space for OPEC to be formed without the prior backlash that was visited upon certain individual producing countries seeking concessional revisionism. Specifically these were the following: the changing nature within the supply and demand dynamics in the global oil industry, the distinct economic and security circumstances within OPEC Member States, and the beginnings of the breakdown of the home-IOC-host nexus. In the Infancy phase of OPEC's institutional life, many of these same factors that contributed to the Organization's formation carried over, evolving and expanding in their complexity.

This rendered many openings for the institutionalization of OPEC, and its development into a legitimate international organization that the international oil companies (IOCs), major powers, and other important global institutions eventually had to take seriously. Though during this period, as Bassam Fattouh has noted, "OPEC acted as a trade union whose main objective was to prevent the income of its member countries from declining," ${ }^{160}$ it managed to integrate many of the contradictions between its Members domestic priorities and inter-Member rivalries with that of the collective Organization's stated objective of price and export collaboration.

Within this phase, the determinants that created the conditions for OPEC's formation became fully distinguishable and interactive, affecting both the Organization's behavior and how other actors interacted with it. Pertaining to Market Forces, the same

\footnotetext{
${ }^{160}$ Fattouh, "An Anatomy of the Crude Oil Pricing System," 15.
} 
supply and demand dynamics that forced the IOCs to continue to devalue the posted price of crude (to keep market share dominance), were creating major ripple effects within the international system. As cheap Soviet oil began to expand into the market, complemented by the rise of smaller, independent oil firms, which were successful in bringing online new sources of crude, the IOCs found themselves devoid of other options than to keep the posted prices low. The damage that this was causing to OPEC Member states, and other significant producers in the third world, now become fully embedded in the macro geopolitical environment of the time, namely the Cold War. Thus, the impact of Outside Actors on OPEC, particularly of America as the guarantor of the home-IOC-host nexus, underwent a major transformation during this period. The reigning Cold War dynamics and the fear of Soviet exploitation of instability within the third world gradually broadened the strategic concerns of the West towards political and economic issues. ${ }^{161}$ And in light of the acute economic and security crises that were transpiring within OPEC Member states, Washington gradually evolved from its policy of conscious indifference to OPEC's creation, to the inevitable conscious acceptance of the Organization, later to be complemented by active engagement with the Group.

The gradual divergence that occurred between the major IOCs and the Western powers, exacerbated by the internal economic instability within OPEC Member States, had a direct impact on the relations with the Organization. The Interstate relations of OPEC Members provided much of the rationale for delay and deadlock. However, they also led to the expansion of the Group and its formalized institutionalization throughout much of the 1960s, in order to collectively challenge what Members felt were the abuses

\footnotetext{
${ }^{161}$ See: Westad, The Global Cold War: Third World Interventions and the Making of Our Times.
} 
of the reigning concessionary system. This ultimately led to action in the form of two tracks of negotiations for more suitable profit sharing arrangements for producers. The first track was individual negotiations between Members and the particular consortium that operated in their territories - primarily because of the unique traits of each concessionary agreement. Later, the negotiations evolved to collective talks with the IOCs, as the Organization developed a formalized mechanism to present their demands to the major oil firms. A main ramification of this process in the Intrastate dynamics of each State was the rise of the national oil companies (NOCs) within individual Member States. In the years ahead, they would gradually replace the technical aspects of exploration, production, and transit of OPEC crude oil. It was the merging of these four key determinants in this period that eventually ended one era in the history of the oil industry, while heralding the beginning of another, leaving the IOCs in a much weaker and isolated position. This process was visible in negotiations between OPEC Member states and the IOCs throughout the 1960's, culminating in the Organization's collective declaratory nationalization in June of 1968 , to be implemented at the beginning of the next period of OPEC's institutional life. ${ }^{162}$

\section{Market Forces:}

The IOCs fight to save their market dominance

From the beginning of the 1960s, the IOCs found themselves between two irreconcilable trends that were threatening their short-term market share dominance, with the potential to erode their power over the very global industry they helped create. As cheap Soviet oil,

\footnotetext{
${ }^{162}$ OPEC, Opec Official Resolutions and Press Releases 1960-1990, 61-62.
} 
in addition to the new sources of supply from the independents, gradually crept into the market, fostering a much less regulated, free market, the IOCs were forced to expand output in hopes of drowning out competitors, while also keeping the posted price of crude at low rates. Already, by 1960, the IOCs had witnessed their domination over global crude oil production outside of Canada, the USSR, China, and the US noticeably decline from $85 \%$ possession to $72 \% .{ }^{163}$ Though the increase in production outside the majors' control and the subsequent lowering of the posted price became the impetus behind the creation of OPEC, the Organization's formation was not the only unintended consequence of how the major IOCs addressed the problem of new competition. As stated previously, while OPEC's formation caused much alarm to the IOCs and caused confusion to Western powers, from a macroeconomic perspective, as Fadhil Chalabi, OPEC's former General Secretary has argued, the creation of the Organization essentially slowed the growing instability within the global oil industry. ${ }^{164}$ Chalabi makes the case that had the "fierce competition of price cuts in a free market not been curbed by some form of restrictive regulation, the continued slashing of prices would have led to a level of competition harmful to the industry and to the major oil companies themselves." 165 Though the Organization would gradually challenge the IOCs in new ways, its initial establishment helped stem the tide of continued mass price erosion, which would invariably have major negative consequences for both companies and producing countries.

\footnotetext{
${ }^{163}$ F.J. Chalabi, Oil Policies, Oil Myths: Analysis and Memoir of an Opec 'Insider' (I. B. Tauris, 2011), 41.

${ }^{164}$ Ibid., 42.

${ }^{165}$ Ibid.
} 
Yet, by the time of the Group's founding, and well into the 1960s, certain trends had already begun to take shape that the IOCs would not be able to control in the longterm. In the year of OPEC's founding, the share of global oil production from what were to become the five initial Members of the Organization was $37.58 \%$, which was wholly controlled by the Seven Sisters, plus the French Compagnie Française des Pétroles (CFP). ${ }^{166}$ Total global oil production in 1960 amounted to roughly 21 billion barrels. The market flooding policies of the IOCs, with the steady increase in Soviet output and that of the independents caused the world to witness an unprecedented surplus, so that by the end of the decade, in effect the end of the Infancy period, global production was almost double that of $1960 .{ }^{167}$

Despite the fact that the IOCs were successful at keeping their competitors at bay, they were also in a race against time, for the short-term achievement of their output policies in order to keep intact their cartel's integrity was more of a pyrrhic victory than a lasting solution. The 1960 reduction in the posted price, from roughly $\$ 1.90$ to $\$ 1.80$ per barrel (which being adjusted for inflation in 2013 would be $\$ 14.84$ to $\$ 14.06$ ), ${ }^{168}$ could not be increased by reason of the new presence of the USSR and the independent oil companies.

\footnotetext{
${ }^{166}$ See: http://www.opec.org/opec_web/en/data_graphs/40.htm (accessed September 15, 2012)

${ }^{167}$ OPEC statistics cites global oil production in 1968 as roughly 38 billions barrels, while the BP Statistical Review of 2012 cites roughly 40 billion barrels. See: http://www.opec.org/opec_web/en/data graphs/40.htm (accessed September 15, 2012) \& http://www.bp.com/sectionbodycopy.do? categoryId=7500\&contentId=7068481 (accessed November 1 , 2012).

${ }^{168}$ See: http://www.bp.com/sectionbodycopy.do? categoryId=7500\&contentId=7068481 (accessed November 1, 2012).
} 
The IOCs' responses to new competition, which directly contributed to the decrease of the revenues of producing countries at a critical juncture in their economic and security development, not only began to build mass resentment within OPEC but also led to further unintended ramifications. Though causing much economic pain to OPEC Members, the IOCs' oil war against the USSR and the independents had the converse effect of gradually increasing the importance of the Organization's Member states to the global oil industry (See Figure 2.1). During this period, as the IOCs increased output volume, much of which came from Member states, OPEC's collective share of global oil production substantially increased from its 1960 figure of $37.58 \%$, - when it had only 5 Members - to approximately $49 \%$ in 1969 - when its membership increased to 9 Members (See Figure 2.2). ${ }^{169}$

By the early 1970s, more than half of total global oil output came from OPEC.

The net result, as will be discussed in the subsequent sections, was to increase OPEC's collective bargaining position vis-à-vis the major IOCs in rearranging both the terms of the concessions and the pricing systems. Thus, in challenging the new Soviet and independent oil firms for continued market share dominance, primarily at the expense of OPEC Member states, the IOCs not only created the impetus for the Organization's formation, but also its internal expansion, increasing the importance of OPEC to the global economy, which the Organization later leveraged to its benefit.

\footnotetext{
${ }^{169}$ See: http://www.opec.org/opec_web/en/data_graphs/40.htm (accessed September 15, 2012)
} 
Figure 2.1: OPEC Crude Oil Production by country, as Members joined the Organization. 1960-1971 (1000 b/d) Source: OPEC Statistical Data . http://www.opec.org/opec_web/en/data_graphs/330.htm

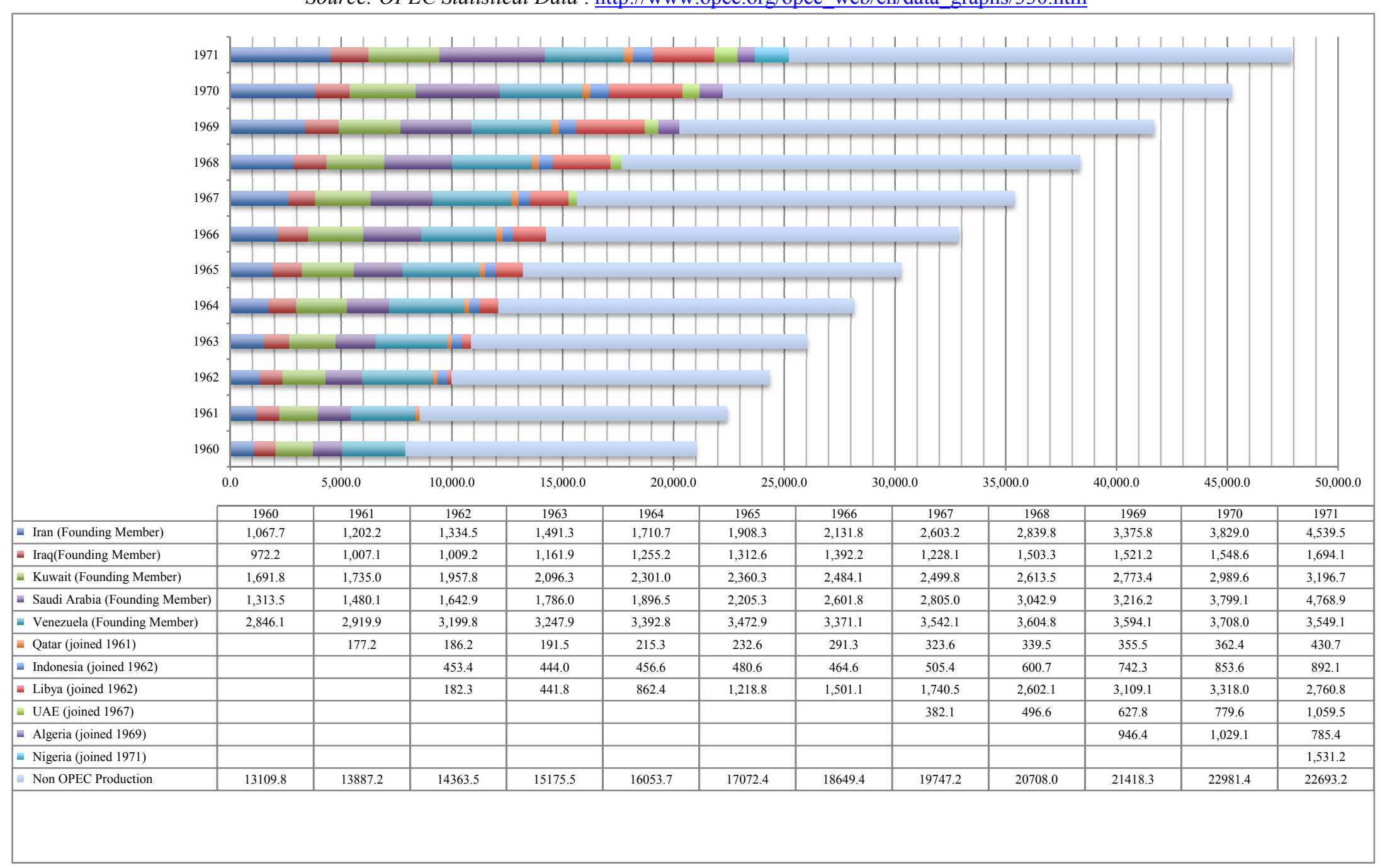


Figure 2.2: Shares of global oil production between OPEC \& non OPEC producers: 1960-1971

Source: OPEC Statistical Data . http://www.opec.org/opec web/en/data graphs/330.htm

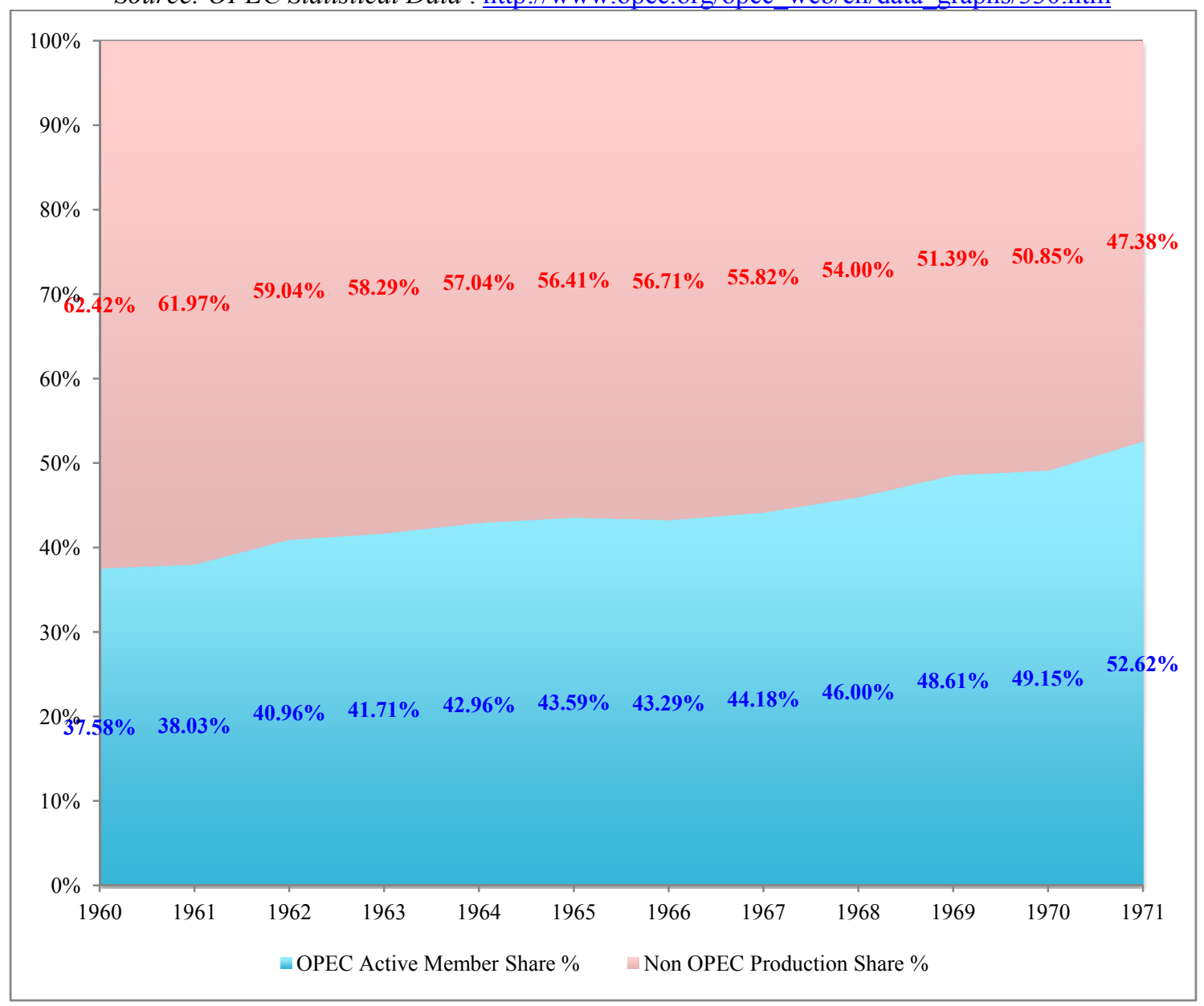

\section{Outside Actors}

Triangulating between the IOCs and OPEC

In light of OPEC's increasing importance to the global economy, coupled with the economic and security vulnerabilities within Member states, all in the background of Cold War power politics, the US position regarding the newfangled Organization, described earlier as conscious indifference, was no longer tenable. The American perception of the altering dynamics within the global oil industry, in the wake of OPEC's formation and growing reliance of the West on Middle Eastern oil was summarized in a 
meeting of the Interdepartmental Committee of the US Under Secretaries on Foreign

Economic Policies in December of 1961. In what was alluded to as the "broad

international problem" concerning the global oil industry, the participants stated:

... that not only does the Free World get two-thirds of its oil from the Middle East now but that 50 years from now it will probably be even more dependent .... From the security standpoint of our longer-term interest in the broadest sense, we must consider what kind of arrangements we can work out to insure Free World access to Middle East oil. Already we have an irrational situation in the Middle East producing and distributing situation. It is irrational not only economically but politically. The international oil companies within the borders of these countries are in a position to dominate completely the political life of the countries because the companies are the source of the bulk of the Governments' revenues. The companies are earning enormous amounts of money and this is resented. This makes them a likely target for the worst kind of attack on political and economic grounds. On the other end of the spectrum, the companies themselves are faced with all kinds of problems. They are faced with the surpluses of stocks and capacity, with increasing competition of substitutes, with new oil discoveries which jeopardize their traditional markets, with competition from Soviet oil, with having to use their Middle East profits to cover costs of explorations elsewhere that prove sterile, with the constant demand of the Middle East Governments for a larger share of oil revenue, and with no flexibility on prices. These all add up to a serious state of tension. As a result our oil companies are handicapped in other less developed countries where the Soviets use cheap oil and oil exploration to penetrate the countries. Shall Western companies try to compete with the Soviets in price?...The companies are in difficulty on exploratory concessions. They come in and spend lots of money and if they don't find oil, they are faced with the charge that they didn't really want to as it would have cut down on their Middle East profits. Then the less developed countries say they will ask the Soviets to come in. The companies are scared of OPEC because they don't think the people running it have a sufficient understanding of the economies of oil. They are frightened that the OPEC Governments will put international prorationing into effect. Then there is the problem of the European countries in connection with the Soviet oil offensive. The average person in Italy gets his oil cheaper because Italy is importing Soviet oil. Industrialists in Europe can produce at less cost because of Soviet oil. It is hard, under those circumstances, to work up resistance to imports of Soviet oil. Our argument has to be the danger of dependence on Soviet oil. 
170

What Washington realized a year after OPEC's founding was that cheap Soviet oil in addition to alternative supplies from independent firms, were creating new market conditions that the majors could no longer control in the long term. This was already having consequential geostrategic effects in vital European and developing countries. Though the IOCs' increase in production was helping to keep the Soviets and independents at bay, there were still what amounted to be losses in key theatres, particularly the growing dependence of some critical markets on cheap Soviet oil and other new suppliers.

The resulting surplus in the market in turn exacerbated the internal economic conditions within OPEC Members that were beginning to take shape before the Organization's founding. The IOCs were simply not in the position to increase prices, as to offset OPEC Member states' growing, albeit differing, budgetary liquidity problems. And because the US dramatically feared Soviet exploitation in countries that were undergoing economic and political instability, evinced by US financial and political intervention in post-WWII Europe in the form of the Marshall Plan, ${ }^{171}$ its policy of neutrality between OPEC and the oil companies became increasingly strained.

\section{US Aid}

The beginning of Indirect American influence within OPEC

\footnotetext{
${ }^{170}$ Summary Minutes of Meeting of the Interdepartmental Committee of Under Secretaries on Foreign Economic Policy, December 13, 1961, Foreign Relations of the United States, 1961-1963

Volume IX, Foreign Economic Policy,

${ }^{171}$ See: Leffler, For the Soul of Mankind: The United States, the Soviet Union, and the Cold War.
} 
Realizing that the major firms could not fundamentally reverse the price erosion of recent years, and being equally aware of the mounting fiscal and security pressures upon OPEC Member states, the US began to strategically shift to a more activist policy towards OPEC Members and those that would eventually join the Organization. This repositioning by the US, culminated in two trends during the 1960s: the beginning (or significant enhancement) of US economic and military aid to some key OPEC Member states and later, the gradual, albeit reluctant, role of the US as a silent broker to the negotiations between OPEC Members and the IOCs on concessional revisionism.

Due to the varying budgetary problems affecting governance matters, and in the case of Saudi Arabia and Iran, distinct security threats that required significant state resources to address, key OPEC Members, starting from the late 1950s, individually began asking the US for economic and security aid. Although it had received significant US assistance since the ouster of Prime Minister Mossadegh to buttress its staggering economy, the aid that Iran was receiving was set to expire. As the Kennedy administration took office in January of 1961, one of the earliest communications that President John F. Kennedy received was from the Iranian Shah, Mohammad Reza Pahlavi, written on the $26^{\text {th }}$ of January 1961, which was a plea for enhanced economic and military aid. ${ }^{172}$

In his communications in the subsequent months, the Iranian monarch consistently reminded the US president that his regime was "trying very hard to put [Iran's] house in order," having "adopted stern measures to achieve a healthy economic

\footnotetext{
${ }^{172}$ Correspondence from Shah Mohammad Reza Pahlavi to President John F. Kennedy. 26 January 1961. Papers of John F. Kennedy. Presidential Papers. President's Office Files. (\#3), 8/7/1961, folder "Iran: Security, 1961-1963,” Box 119, John F. Kennedy Library.
} 
and financial situation." ${ }^{173}$ Yet, according to the Shah, "in order to remain under the present difficult situation and against the pressure of international communism" Iran needed, "both in the economic and military fields...continued American help, or rather, in all earnestness, for increasing American help.” 174

Furthermore, in addition to the challenges within the Iranian economy and the threats coming from the USSR, the Shah explicitly mentioned the threat from Sovietaligned regional Arab regimes, specifically how they were receiving funding and military assistance from Moscow, and their attempted interventions in Iran's domestic affairs. ${ }^{175}$ To the Shah, both of these processes threatened to tilt the regional security architecture against Iran. ${ }^{176}$ And though some within the US administration were skeptical about continual, let alone enhanced aid to Iran insisting that "through a variety of unpleasant measures the Iranian budget can be handled without the crutch of US budgetary assistance," ${ }^{177}$ ultimately, the administration relented to the Iranian request.

The Shah's repeated pleas was only buttressed by the recommendations of the US National Security Council's Task Force on Iran, sketched out in their report, "A Review of Problems in Iran and Recommendations for the National Security Council", which

\footnotetext{
${ }^{173}$ Correspondence from Shah Mohammad Reza Pahlavi to President John F. Kennedy. 9 July 1962. Papers of John F. Kennedy. Presidential Papers. President's Office Files. (\#3), 8/7/1961, folder "Iran: Security, 1961-1963,” Box 119, John F. Kennedy Library.

${ }^{174}$ Ibid.

${ }^{175}$ Correspondence from Shah Mohammad Reza Pahlavi to President John F. Kennedy. 1 June 1963. Papers of John F. Kennedy. Presidential Papers. President's Office Files. (\#3), 8/7/1961, folder "Iran: Security, 1961-1963,” Box 119, John F. Kennedy Library.

${ }^{176}$ Ibid.

${ }^{177}$ Memorandum from William H. Brubeck to McGeorge Bundy. 27 July 1962. Papers of John F. Kennedy. Presidential Papers. President's Office Files. (\#3), 8/7/1961, folder “Iran: Security, 1961-1963,” Box 119, John F. Kennedy Library.
} 
recommended a robust economic and military assistance package to blunt the economic problems and security threats facing the country. ${ }^{178}$

As a result, the US decided to forgo the upcoming cancellation of aid to Iran, and assured the Shah with a five-year aid plan. Though economic aid to Iran steadily decreased from the post-coup period, it was only countered by a major increase in military aid - which was where the brunt of the Shah's concerns lay. Indeed, Iran, by far, was the highest recipient of US aid to the Members of the Organization from 1960-1970, totaling $\$ 7.2$ billion (in 2011 figures) (See Figures $2.3 \& 2.4$ ). This same pattern was applied to other Member states. Indonesia, which joined the Organization in 1962, had for years been a recipient of US aid. Nevertheless, from the mid-1960s to the end of the decade, it witnessed a dramatic increase, totaling $\$ 4.2$ billion, mostly economic in nature, making it the second largest recipient of US assistance in OPEC.

As in the cases of other Members, Washington's fear of Soviet exploitation of the dire economic and security conditions within Indonesia became the principle driving force behind US aid. ${ }^{179}$ This was only exacerbated by a strong domestic presence of communist political parties and the fact that Indonesia's Sukarno government was openly receiving aid from the Soviet Union, placing Washington in a position where it had to compete with Soviets in Indonesia. ${ }^{180}$ In addition to assistance, the US played an active

\footnotetext{
${ }^{178}$ National Security Council, 15 May, 1961, folder “Iran: General, 15 May 1961,” Papers of John F. Kennedy. Presidential Papers. National Security Files. (\#3), Box 115, John F. Kennedy Library.

${ }^{179}$ Telegram From the Embassy in Indonesia to the Department of State, 25 January 1961, Foreign Relations of the United States, 1961-1963 Volume XXIII, Southeast Asia \& Memorandum From Secretary of State Rusk to President Kennedy, 22 April 1961, Foreign Relations of the United States, 1961-1963 Volume XXIII, Southeast Asia

${ }^{180}$ Telegram From the Embassy in Indonesia to the Department of State, 7 March 1961, Foreign Relations of the United States, 1961-1963 Volume XXIII, Southeast Asia \& Memorandum From the Joint Chiefs of Staff to Secretary of Defense McNamara, 13 October 1961, Foreign Relations of the United States, 1961-
} 
role on behalf of Indonesia with its dealings in International Monetary Fund (IMF), and with other important institutions, to facilitate the country's development plans. ${ }^{181}$

In Venezuela, under the Betancourt administration, and in reaction to declining oil revenues, the government also had explicitly asked Washington for aid, ${ }^{182}$ and was able to secure $\$ 1.6$ billion in economic and military aid over the decade. Saudi Arabia, with its more pressing security concerns as a result of the instability within Yemen, the Iraqi Revolution of 1958, and the continuous hostility from Gamal Abdel Nasser's UAR government eventually garnered the "full United States support for the maintenance of Saudi Arabia's integrity, " 183 with the addition of $\$ 1.2$ billion in military aid in the same period. Even Iraq, whose political elite, after its revolution, had great suspicion towards the US and its regional intentions, received, albeit a very small package, a little more than $\$ 150$ million in US aid in the 1960s. In total, US aid to OPEC Member states, from 19601970 , was roughly $\$ 8.5$ billion in the economic sphere and $\$ 7.6$ billion in military assistance.

Though the rationale behind American aid was initially a stopgap measure to stabilize these critical producing countries, and also motivated by concerns regarding Soviet intentions towards these states, the purpose of aid eventually evolved. In part, the

1963 Volume XXIII

${ }^{181}$ Memorandum From the Under Secretary of State (Ball) to President Kennedy, 10 October 1961, Foreign Relations of the United States, 1961-1963 Volume XXIII

${ }^{182}$ Memorandum of conversation, May 5, 1961, between Perez Guerrero and Bowles and other U.S. and Venezuelan officials. Request by the Special Financial Mission from Venezuela for U.S. assistance with its economic development program. Official Use Only. 2 pp. DOS, Secretary's Memoranda of Conversation: Lot 65 D 331. John F. Kennedy Library.

${ }^{183}$ Memorandum from William H. Brubeck to McGeorge Bundy, 22 December 1962, folder " Saudi Arabia: 1961-1963” Box 119, Papers of John F. Kennedy. Presidential Papers. President's Office Files. John F. Kennedy Library. 
US realized that as OPEC was beginning to create its internal decision-making organs where the diversity of its Members' policies could be streamlined into a macro institutional policy, the possibility of more forceful demands from the Organization on the IOCs could not be ruled out. And as negotiations between OPEC and the IOCs were beginning to take shape shortly after the establishment of the Organization, albeit on an individual basis between the concession holders in a particular country and that respective government, collective negotiations through the Organization could possibly become inevitable.

The US could not afford to remain indifferent to such an event, but as stated previously, was unable to take an active position, either for or against the Organization. Thus, with the aid that was being given to OPEC states, although on a case-by-case basis, the US intended to generate some modicum of influence within the Organization. In doing so, as was recommended by the Eisenhower administration and some IOCs in the year of OPEC's founding, the US sought to exploit the natural divisions concerning each Members' outlook on the concessionary system, and according to the unique vulnerabilities that each state had. Naturally, the Members that would end up receiving the most aid and security guarantees from Washington would become the vehicle wherein US policy preferences and concerns would appear within the Organization. 
Figure 2.3: U.S. Economic Aid to OPEC Member States: 1950-1971 (adjusted to 2011 \$ figures)

*Angola, Kuwait, Qatar, and the UAE did not obtain Aid during this period. Source: USAID

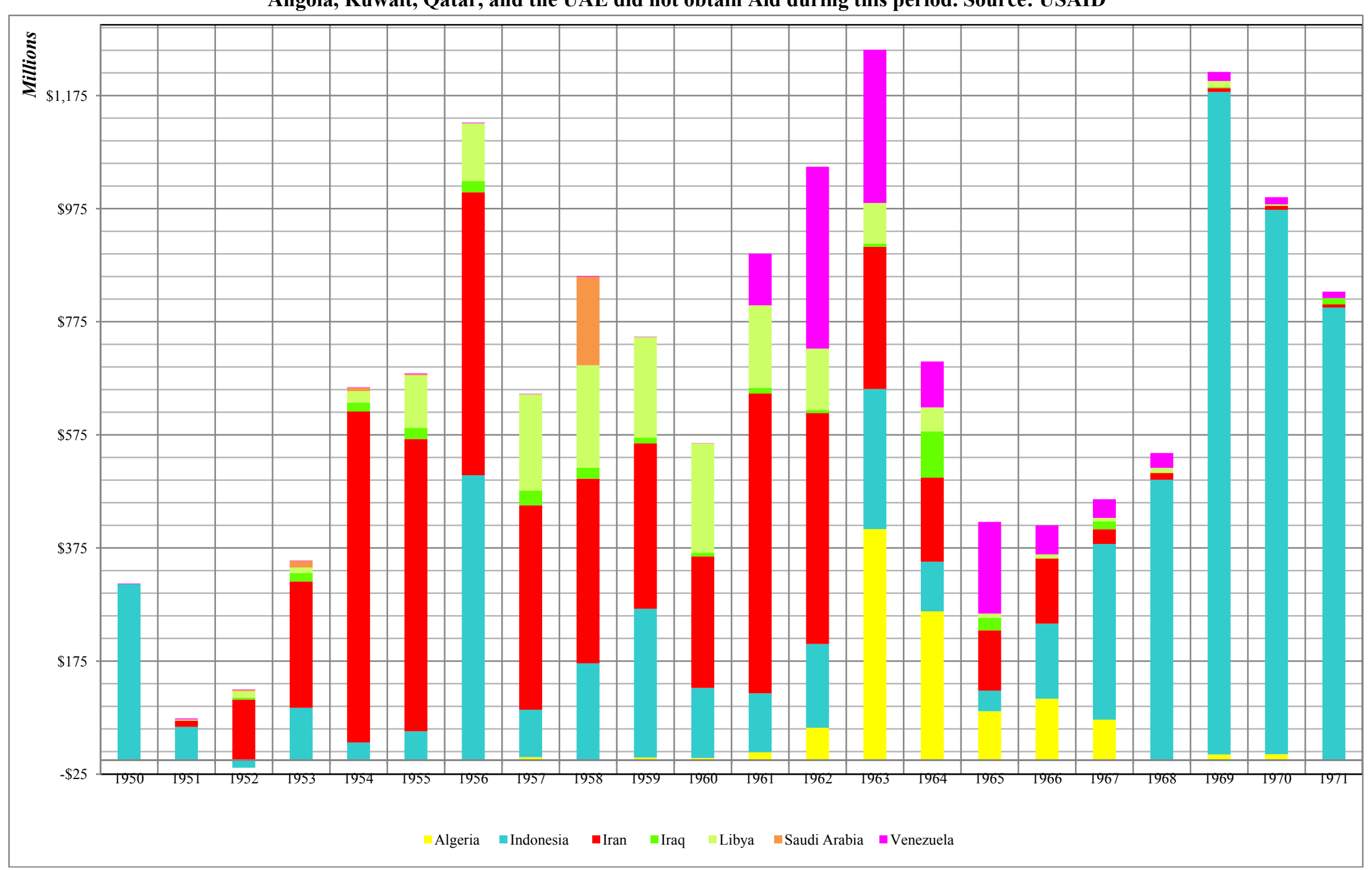


Figure 2.4: U.S. Military Aid to OPEC Member States: 1950-1971 (adjusted to 2011 \$ figures)

*Algeria, Angola, Kuwait, Qatar, and the UAE did not obtain Aid during this period. Source: USAID

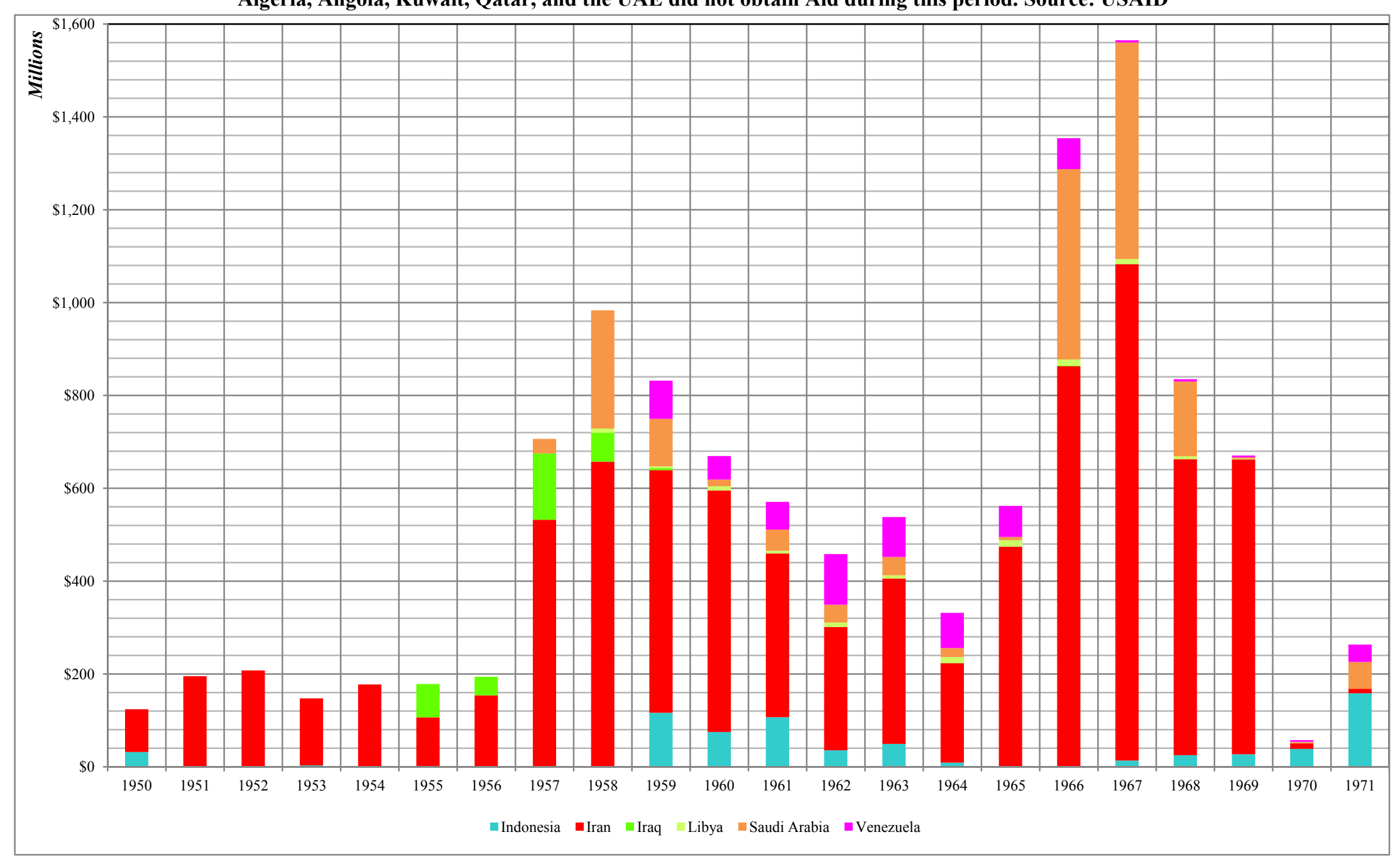




\section{Intrastate Dynamics}

The economic dilemmas facing OPEC Members were not the only internal factors that impacted how outside forces would deal with the Organization in the beginning years of its institutional life. Gradually, these concerns broadened to exclusively political matters as well. During this period, two major developments within the internal domestic climate of OPEC Member states proved to be consequential. The first centered on the political typology of OPEC Member States, fundamentally impacting the relationship between Member States and outside actors, and the larger international system. The second concerned the rise of the National Oil Companies within Member states. The governmental entrance in the producing countries production and export policies would eventually affect how OPEC would function as a unitary entity vis-à-vis the major international oil companies, and how the individual constituents of the Group ultimately dealt with the nationalization of their hydrocarbon resources.

\section{The Domestic Political Landscape}

Up until this period, it was only Iran and Iraq that had consequential domestic governance changes: for Iran, the rise and fall of Mohammad Mossadegh and the reassertion of the Pahlavi monarchy; for Iraq, the 1958 military overthrow of the Hashemite dynasty and the creation of Republican Iraq under military rule. Yet, during the 1960 s, with the exception of Venezuela that had a stable democratic transition from the Betancourt administration (1959-1964) to the Leoni administration (1964-1969), which continued the same economic structural reforms as its predecessor, ${ }^{184}$ every other

${ }^{184}$ H.M.T. Denova and J.C. Frederick, The History of Venezuela (Greenwood Press, 2005), 106-19. 
Member had far-reaching alterations within the socio-political dynamics of their respective countries.

From 1960-1969, of the nine Member States of OPEC, five experienced change of governments via coup d'états - some of which were bloodless (namely Saudi Arabia, Libya, and Algeria), while others were bloody (namely Iraq and Indonesia). In time, the arrival of new political orders or altered socio-political conditions within Member countries had a far-reaching effect on how crude oil production was utilized for the economic health of their countries by each respective government, and also their respective roles within OPEC. For Kuwait, Qatar, Algeria, and what eventually became the UAE, it was in this Infancy phase when their independence as sovereign states was established. In many ways, what happened during this period on the socio-political level not only laid the groundwork for the future internal and external political behaviors of these countries, but also their impact upon OPEC unity, and when the time came, disunity. While the domestic political developments in each country were important, both for the particular Member state and eventually the Organization, in Iran, Iraq, and Libya they proved to be the most consequential for the future of OPEC.

In Iran, a reinvigorated Mohammad Reza Pahlavi, having secured aid from the US but also keen on diminishing any type of threat to his rule, began, in the early 1960s, the process of implementing his 'White Revolution' in Iranian society. This dramatic plan was advertised as an attempt to modernize Iranian society, both socially and economically, in which the government would address such issues as woman's rights, economic growth predicated upon the Western capitalist model, and a restructuring of 
land ownership. ${ }^{185}$ To embark on such modernization plans, the Shah heavily relied on US aid, which Iran was receiving at that time - chiefly US military aid - which allowed the Shah to spend more domestically. However, the practical results of the Shah's efforts was to erode the power of the traditional, land-owning aristocracy, thus lessening the likelihood of political competition, creating the conditions where Iran's urban middle class would be politically disarmed by becoming invested in the Shah's reforms. ${ }^{186}$ And this would transpire as the Pahlavi regime created a new middle class from Iran's peasantry that would invariably become dependent upon the government. Naturally, many within Iranian society protested these dramatic measures. While this process was underway, the Shah targeted the domestic forces within Iran that could be characterized on the political left, and the small groups that were deemed sympathetic to the USSR. Yet, with time, the ramification of these policies, although bringing some tangible material benefit to the poor, were essentially to renew resistance to the Shah, and in the process create a religious based opposition that would eventually fuse their grievances against the gradually authoritarian bent of the Shah's regime. ${ }^{187}$ As we will be discussed subsequently, while the Shah would become the moderating influence within OPEC, particularly during the negotiations between the Organization and the IOCs, it was this very program, along with other modernization efforts, and his desire for a massive overhaul of the Iranian armed forces that would eventually reorient his government's

\footnotetext{
${ }^{185}$ Rouhollah K. Ramazani, "Iran's 'White Revolution': A Study in Political Development," International Journal of Middle East Studies 5, no. 2 (1974): 124-39. \& James A. Bill, "Modernization and Reform from Above: The Case of Iran," The Journal of Politics 32, no. 1 (1970): 19-40.

${ }^{186}$ Arjomand, The Turban for the Crown: The Islamic Revolution in Iran, 71-99.

${ }^{187}$ E. Abrahamian, Iran between Two Revolutions (Princeton University Press, 1982), 500-30.
} 
thinking on the profit sharing arrangements with the IOCs, the very continuity of the concessionary arrangements, and the overall price of crude oil.

In Iraq, the overthrow of the Hashemite dynasty, two years before the creation of OPEC, had brought about both confusion and worry among the conservative monarchial Middle Eastern governments allied with the West, and for the US itself. Initially, the American perception concerning the 1958 Revolution was at best mixed, primarily because of the contradictory moves that Iraq's new post-monarchial leader, General Abd al-Karim Qasim, made during the first few months. The US preliminary assessment was not that he was fully aligned with the Soviet Union, although with his arrival, Iraq did leave the Baghdad Pact and ostensibly warmed relations with the USSR. The American discernment of Qasim's move was viewed as either being domestically forced upon him to adjust his foreign policies or an unwillingness or inability to stand against those looking to balance relations vis-à-vis the US and the Soviet Union. ${ }^{188}$ However, on a regional level, the assessment of Republican Iraq quickly deteriorated, though Baghdad had initially reached out to regional countries that would eventually become OPEC Members and even hosted the first OPEC conference. Qasim's continuing annexation threats against Kuwait, which came to a head in the wake of the latter's independence in 1961 (forcing Kuwait to ask for British military assistance), and his territorial claims against Iran's Khuzestan, gradually created enmity towards Iraq among differing, and at times rival regional actors. Moreover, the domestic balancing act that he was forced to undertake in order to pacify the coalition of disparate constituencies in Iraqi society

\footnotetext{
${ }^{188}$ Memorandum From the Assistant Secretary of State for Near Eastern and South Asian Affairs (Rountree) to Acting Secretary of State Dillon, 22 December 1958, FRUS, 1958-1960, Vol. XII, pp. 368371.
} 
ultimately proved paralyzing to his rule. And his inability to solve the country's economic crisis, by extracting more concessions from the major IOCs that held the consortium in Iraq further undermined his rule. With time, the US not only became gradually suspicious of his rule, but also eventually reached out to domestic forces within Iraq that sought to remove Qasim, who at that time was the Prime Minister.

When the Ramadan Revolution of 1963 took place, initiated by the Baath Party within Iraq, there is evidence that while the US may not have been overtly complicit in the removal of Qasim (in the same manner that the US and UK engineered the coup against Mossadegh), it certainly stood by and did not impede the Baathists as they took control over the country. ${ }^{189}$ Moreover, immediately afterwards, the US did provide Iraq with a modest amount of economic assistance, which included access to US military hardware, credits for agricultural surpluses for credit under Public Law 480, and ExportImport Bank loans. ${ }^{190}$ Though not known at the time, the Ramadan Revolution, ultimately led to a 5-year interim of national, and often bloody, political turmoil where pro-Nasserite and pro-Baathist forces fought for control over the country, culminating in the consolidation of the Baathist Party in 1968, led Ahmed Hassan al-Bakr and his ambitious deputy, Saddam Hussein. Needless to say, the latter's political rise would not only change the face of the political and social direction of the country, but would have profound ramifications for the future of OPEC's unity and for the Middle East in the years ahead.

\footnotetext{
${ }^{189}$ Harry August Rositzke, The Cia's Secret Operations: Espionage, Counterespionage, and Covert Action (Westview Press, 1977), 108-09. \& Memorandum for The President from Robert W. Komer, 8 February 1963 (JFK, NSF, Countries, Iraq, Box 117, "Iraq 1/63-2/63", document 18), p. 1., JFK Library.

${ }^{190}$ See: Eric Jacobsen, "A Coincidence of Interests: Kennedy, U.S. Assistance, and the 1963 Iraqi Ba’th Regime," Diplomatic History (2013).
} 
In Libya, when the coup against King Idris happened in September of 1969, the country's oil production, though modest, was not a major factor in the total OPEC output, and certainly not global output. For this reason, at the outset, there were very little political reverberations outside Libyan borders. The US' initial assessment of the young military officers behind the coup was that they showed "some moderation", promising to "protect foreign interests, including oil companies." ${ }^{191}$ However, the US understood that, similar to the Iraqi Revolution of 1958 - where a monarch was overthrown by the military - the political change in the country had "created a precedent which will not be forgotten" and that "the moderate posture of the Libyan regime is probably temporary," with caveat being that there were no "good grounds" for forecasting if or when the new government would settle into a policy. ${ }^{192}$ The CIA specifically based their assessment on past military-dominated revolutionary regimes in Arab World, citing that "without exception", the political order after the former regimes tended to be "more leftist and extreme with the passage of time." ${ }^{193}$ With this cautious assessment, American leaders, along with the British, chose to move towards recognition of the political change in Libya,

\footnotetext{
${ }^{191}$ Memorandum From Harold Saunders of the National Security Council Staff to the Special Assistant to the President's Assistant for National Security Affairs (Lake) for the President's Assistant for National Security Affairs (Kissinger), Washington, 2, September 1969, FRUS, 1969-1976, Volume E-5, Part 2, Documents on North Africa, Document 37.

${ }^{192}$ Intelligence Memorandum, Washington, 16 September 1969, FRUS, 1969-1976 Volume E-5, Part 2, Documents on North Africa, 1969-1972, Document 39

${ }^{193}$ Ibid.
} 
194 even as some US regional allies were alarmed by the American passivity towards the coup. 195

Yet, weeks after Idris' downfall, the US perception of the political change in Tripoli dramatically worsened. The new regime's behavior quickly became hostile to both Western enterprises and towards American and British military bases within their country, changing Washington's characterization of the "new Libyan government as insecure, inexperienced, xenophobic," and "perhaps divided but as yet without visible opposition." 196 Subsequently, Washington ordered a thorough revision of its policies towards Libya, ranging from cutting off of relations to overt acts of economic and even military hostility. ${ }^{197}$ But even in the American NIE of December of 1969, the US still had not developed a clear picture of the changed political order in Libya and particularly of Libya's new young military ruler, Muammar Qaddafi. For Washington, and by extension its European allies, the primary issues of concern were the new government's interaction with Western oil firms, most of which were the smaller independents, and its

\footnotetext{
${ }^{194}$ Memorandum From the Assistant Secretary of State for African Affairs (Newsom) to the Acting Secretary of State (Richardson), Washington, 4 September 1969, FRUS, 1969-1976, Volume E-5, Part 2, Documents on North Africa, Document 38.

${ }^{195}$ Telegram 158075 From the Department of State to the Embassies in Lebanon, Saudi Arabia, and Morocco, September 17, 1969, $2104 \mathrm{Z}$

Foreign Relations of the United States, 1969-1976

Volume E-5, Part 2, Documents on North Africa, 1969-1972, Document 40

${ }^{196}$ Memorandum From Robert Behr and Harold Saunders of the National Security Council Staff to the President's Assistant for National Security Affairs (Kissinger), Washington, 20 November 1969, FRUS, 1969-1976 Volume E-5, Part 2, Documents on North Africa, 1969-1972, Document 44

${ }^{197}$ Ibid.
} 
ongoing negotiations with Tripoli concerning foreign military installations. ${ }^{198}$ It would take a few more months, well into the early 1970s, for the West, fellow OPEC Members, and the wider global economy to gauge the real impact of the Libyan Revolution of 1969.

OPEC as an institution initially viewed what transpired in the disparate domestic contexts of these three Member states, as well as others, as solely internal matters. Throughout the Organization's first decade, in its biannual and emergency meetings and its resolutions, there was scant mention of domestic political developments. As will be discussed in the next section, the negotiations that Member states were involved in with the IOCs, later to become collective negotiations, was the main focus of OPEC's organizational concerns in this critical, Infancy period. However, the seeds that were sown during this period, particularly within these three countries, would have a lasting impact for both the way OPEC would operate in the 1970s and for the long-term unity of the Organization.

\section{The Beginnings of the National Oil Companies}

The second critical internal development within the political and economic dynamics of OPEC Member states was the genesis of the National Oil Companies (NOCs). The mechanism where host countries would gradually exact ownership of the oil industries within their territories, which mostly became institutionalized by reason of their domestic laws and later collectively as OPEC policy, is inextricably linked to the development of what became the Member states' NOCs. While NOCs had very little impact on actual

\footnotetext{
${ }^{198}$ National Intelligence Estimate 36.5-69, Washington, 30 December 1969, FRUS, 1969-1976 Volume E5, Part 2, Documents on North Africa, 1969-1972, Document 50
} 
production during this institutionalization period, negotiations between Members and the IOCs were laying the groundwork and rationale for creating a national entity that would ultimately replace the vital role of the foreign firm in the producing countries. During the first decade of OPEC's institutional life the NOCs were either enhanced from their earlier, rudimentary forms (such as the case with Iran and Saudi Arabia), begin the process of creation by their respective governments, or established in full (See Figure 2.5).

The NOCs of each Member State, though differing in the particular contexts in which they were born, all had one main driving force behind them: the desire by the Member state government for more control over the crude oil that they exported, which also affected subsidiary issues such as price and market access. ${ }^{199}$ Nevertheless, one fundamental distinction became important in both the effectiveness and strength of the NOCs to be a viable alternative to the more technologically advanced IOCs and the 'acceptance' of the respective NOC in the global economy. And this had everything to do with how the process of state control took place. As Valerie Marcel has noted, the NOCs in "the developing world emerged either from nationalization, taking over the expropriated assets of the foreign oil companies, or from 'participation' agreements in which the national oil company gradually filled the shoes of the foreign oil company as the state purchased the company's assets." $200 \quad$ This fundamental distinction is crucial, for it concerns how the respective NOC came about from the larger process of give and take with the IOCs during the negotiations of the 1960s for rearranging the profit sharing agreements. In other words, what was the climate surrounding nationalization? Was it

\footnotetext{
${ }^{199}$ Silvana Tordo, Brandon S. Tracy, and Noora Arfaa Arfaa, National Oil Companies and Value Creation, III vols., vol. I (Washington, D.C. : World Bank Publications, 2011), 15-19.

${ }^{200}$ Marcel and Mitchell, Oil Titans: National Oil Companies in the Middle East, 25.
} 
one in which there was a gradual recognition by both producing country and the majors firms that the respective government, in the post-WWII era, for reasons relating to prestige, sovereignty, legitimacy, and viability, needed to possess control over their own oil resources, and thus a more modern business relationship needed to be established? Or was the way in which nationalization implemented by the host government one which led to animosity or even material loss for outside enterprises, without compensation.

While full nationalization came about in the 1970 s - with varying specific dates for each Member - the conditions for nationalization were set by how each Member's NOC was established. And this latter circumstance fundamentally affected the negotiations of the 1960 s. Near the end of the 1960 s, as talks seemed unable to address the main budgetary dilemmas that plagued the producers, thus laying the groundwork for OPEC's collective declaratory nationalization resolution of June of 1968, the Members' NOC began the process of formal institutional collusion - both in relation to the Organization and among themselves. 
Figure 2.5 OPEC National Oil Companies in their developmental stage
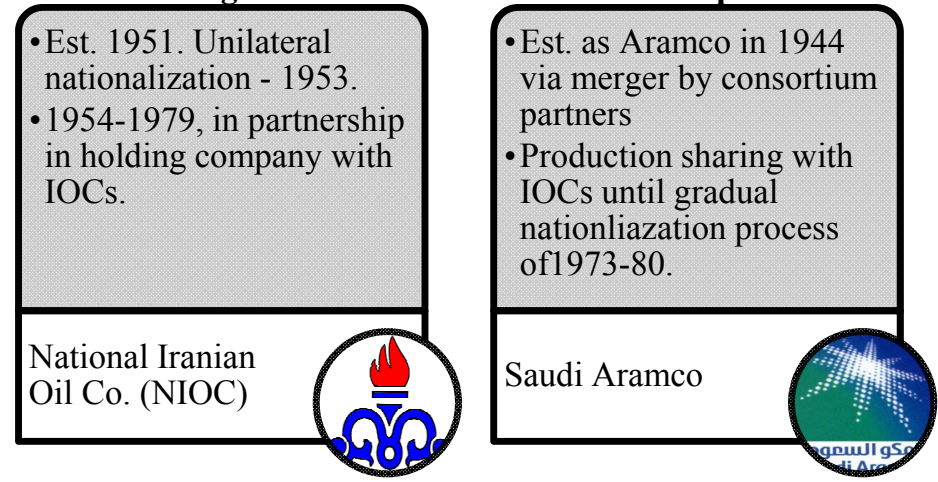

- Est. 1960, productionsharing agreements with IOCs

-Became fully nationalized in 1975

- Now under Kuwait Petroleum Coporation

Kuwait National Petroleum Co. (KNPC)
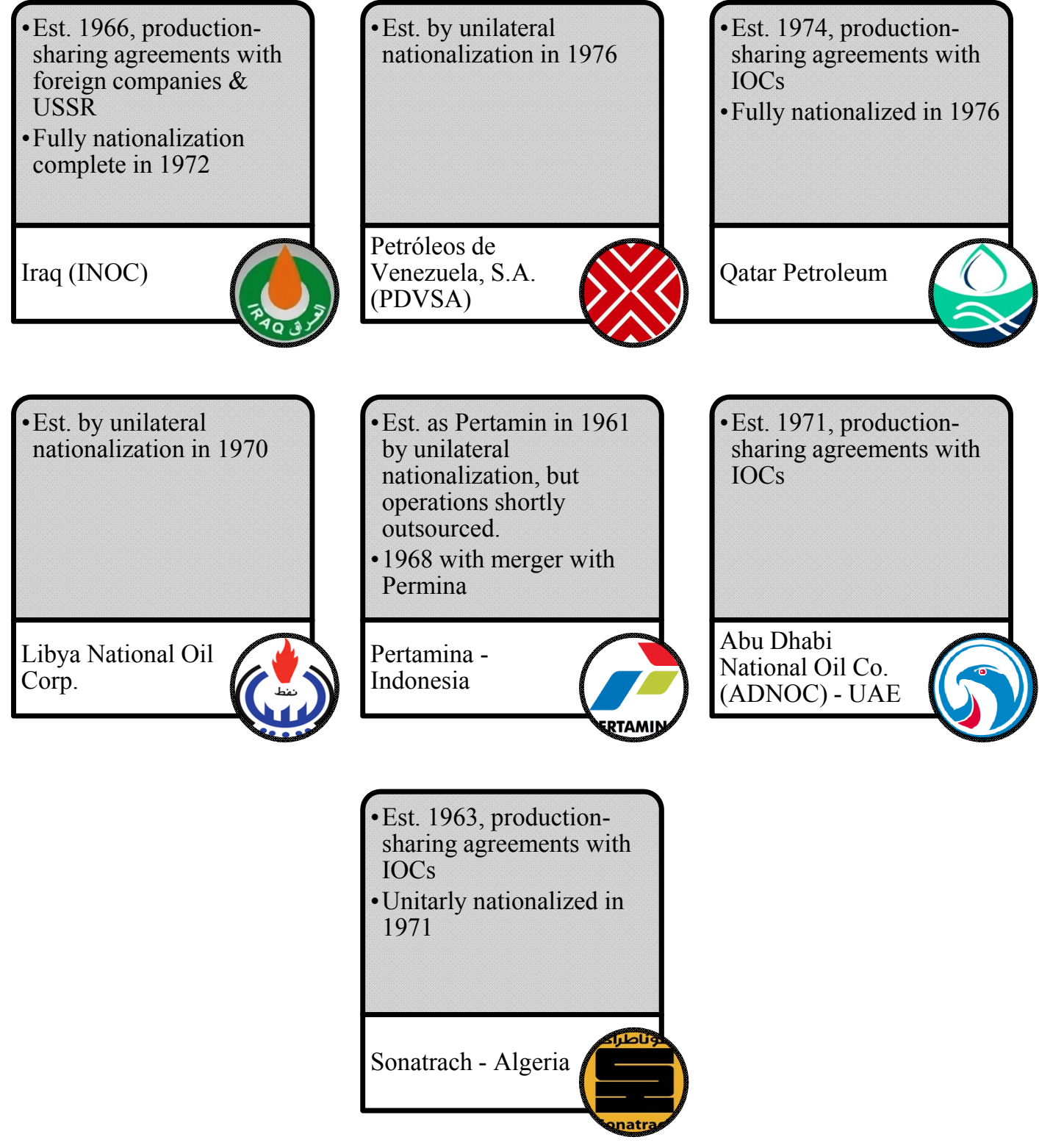


\section{Interstate Dynamics}

\section{Organizational Enlargement and Negotiation}

The combination of the reduction in the posted price of crude with the wider 1960s oil glut was beginning to turn OPEC into a magnet for other producers to join, especially from the Third World. While large, developed economies with hydrocarbon reserves most likely either internally possessed or had access to the technology to recover, produce, and export their crude oil, developing countries - specifically those that were not major producers - had more limited options. A developing country seeking to exploit its reserves, even in the 1960s, had essentially three choices: invite one or more of the major IOCs to join a consortium agreement, look towards the USSR for assistance (but risk engendering American antagonism), or attract the newly arrived independent oil companies for assistance (which were far less technologically sophisticated than the former two). These choices were particularly stark for newly independent countries with little experience exercising sovereignty. However, whatever approach they chose to pursue (and many times these approaches were not mutually exclusive), several producing countries became attracted to the concept of a large international organization run by countries from the developing world, that would, at least in name, become a forum where their voices were heard, and more importantly, their economic interests could be protected.

Because for some future Members, as the Organization was older than their independence, the decision to join OPEC was one of the first acts of sovereignty that some Member states undertook. Within a year after OPEC's founding, the tiny Persian 
Gulf emirate of Qatar, with but modest exports, applied for membership and was accepted without delay. ${ }^{201}$ This was particularly important because Qatar, like the other Persian Gulf kingdoms, except for Saudi Arabia, was still in the process of obtaining, or in this case, being given independence by the British as they gradually withdrew East of Suez. The following year, 1962, newly independent Libya, still in the developmental phase of its oil infrastructure, and Indonesia, a country with respectful production figures still mired in territorial and concessional disputes with its former Dutch rulers, also became Members. ${ }^{202}$ In 1967, in the midst of the negotiations with the IOCs, Abu Dhabi (to be superseded by the larger United Arab Emirates), in the process of gaining its independence from Britain and having virtually no oil production, joined the Organization. ${ }^{203}$ And in 1969, only seven years after its war of independence against the French, Algeria joined OPEC. Similar to Indonesian independence against the Dutch, Algeria faced mass capital flight of the technocratic class, nationalizing what the colonial power and its private enterprises left behind, the most notable being CFP's upstream facilities, with significant damage to country's manufacturing base. ${ }^{204}$ Yet, with very little international support, the Algerian government viewed its Membership in the Organization as both a strategic asset and a refuge.

\footnotetext{
${ }^{201}$ Rouhani, A History of O.P.E.C, 80. \& OPEC, Opec Official Resolutions and Press Releases 1960-1990, 2.

${ }^{202}$ See: Rouhani, A History of O.P.E.C, 80; P.D. Linquiti, Indonesia and Opec: The Economic Costs of Cartel Membership (East Asian Program, The Wilson Center, 1982). \& OPEC, Opec Official Resolutions and Press Releases 1960-1990, 15.

${ }^{203}$ OPEC, Opec Official Resolutions and Press Releases 1960-1990, 56.

${ }^{204}$ See: Phillip C. Naylor, France and Algeria: A History of Decolonization and Transformation (University Press of Florida, 2000).
} 
Though US economic and military aid, along with certain security guarantees, significantly alleviated the internal concerns of the main OPEC producers, there was a limit to what US aid could accomplish for other Members. Libya's entrance into the Organization signaled a fundamental change in the power of the IOCs to persuade governments into accepting the majors' preferences for their crude oil exports. Though a country like Indonesia, the birthplace of modern Royal Dutch Shell, was still heavily dependent on one of the Seven Sisters, the rupture in the home-IOC-host nexus, US neutrality in the post-independence negotiations between Indonesia and the Dutch, and continuous US economic and military support, allowed the Jakarta government to take independent measures, like joining OPEC, for eventually more government revenue and more control. Libya however was different. Unlike other producing countries, Libyan production came online much later, and thus when OPEC was formed, output from Libya was virtually nonexistent. And as the possibility of Libyan oil output was still hypothetical at the creation of OPEC, this made the Tripoli government far more vulnerable to pressures from IOCs and their imposed conditions for discovery and extraction of Libyan crude than that of other producers - chiefly because of the glut in the oil market.

After it gained independence in 1951, Libya's pre-oil economy, with virtually no manufacturing base and a largely decentralized government, was unable to steer the country out of its impoverished conditions. Throughout the 1950s, the Libyans were able to build only a modest agricultural sector, in addition to garnering crucial US aid keeping in line with established US policy of countering Soviet political and economic penetration via economic and military assistance. However, once oil was discovered in 
Libya in 1958, several oil firms became interested in investing in Libyan oil. It was at this moment, as previously stated, where Standard Oil of New Jersey attempted to convince Tripoli of not joining OPEC, pushing a scenario where Libyan oil under OPEC would be economically unattractive to European consumers. ${ }^{205}$ What made matters more perilous for the future of Libyan oil was that its assistance from the US was coming to an end. Indeed, not unlike other Members, Libya's economic health in the early 1960's, in the words of American officials, was in "sheer financial chaos". ${ }^{206}$ Under King Idris, Libya, like other OPEC Members, had received US aid, albeit in moderate amounts. The aid was specifically intended for domestic developmental projects. However, the Tripoli government, possibly because of the excitement surrounding the discovery of oil, corruption, or mismanagement started to increase development plans - predicated on a continuous supply of US aid and the future oil revenue that was too come. However, while aid from the US was arriving, it was decreasing with time (See Figure 2.1). Additionally, though Libya's oil had piqued the interest of many of the major IOCs to the country, the oil glut of the 1960s provided little incentive for the rapid production of Libya's oil. And though Libya, like other Members, viewed OPEC membership as a possible future asset, its reliance upon major IOCs would have allowed the latter to use delays in production as leverage against Tripoli joining OPEC.

In a US State Department cable in 1962, American officials detailed both the extent of Libya's economic woes, but also their strong reluctance of providing aid to

\footnotetext{
${ }^{205}$ Memorandum of Conversation, 19 October 1960. FRUS

${ }^{206}$ Memorandum from R.W. Komer to President Kennedy, 16 October 1962, folder "Libya: 1961-1963", Digital Identifier: JFKPOF-121-040, Papers of John F. Kennedy. Presidential Papers. President's Office Files. John F. Kennedy Library.
} 
Libya. ${ }^{207}$ US officials accused the Libyans of living beyond their means, by profligate spending on oil pipelines, housing units, and other developmental projects, which left the government with little savings and later a substantial budget deficit, while also making commitments to other development projects that they could not afford. In their criticism of Libya's 'lax financial and programming controls', the US advised that the "first job of the government of Libya was to put [its] own house in order and exercise fiscal restraint." 208 Facing declining US aid and pressure from the major IOCs not to join OPEC, Libya discovered that the only means to have both financial security and some modicum of independence in its decision-making was to invite smaller, independent firms seeking new supplies. Not only did this action eventually provide more maneuverability for the Libyan government, but it also allowed Libya's move towards OPEC membership to become feasible. Indeed, it was this action by Tripoli that created one of the first templates for producing countries, particularly OPEC Members, to view contracting with independent companies as a viable means to obtain better revenue sharing terms. And the early image of OPEC providing strength in numbers to the producers was all the more reason for additional producing countries to join.

\section{Building the Organs of OPEC while Individual Negotiations begin}

Simultaneously, other Members were grappling with their own predicaments as it related to the future of the oil industry in their territories, and the profit sharing arrangements with the IOCs. Yet, though OPEC was viewed as potentially a major asset for

\footnotetext{
${ }^{207}$ Department of State Cablegram, 11 October, 1962, folder "Libya: 1961-1963," Digital Identifier: JFKPOF-121-040, Papers of John F. Kennedy. Presidential Papers. President's Office Files. John F. Kennedy Library.

${ }^{208}$ Ibid.
} 
hydrocarbon-endowed countries of the developing world, it still did not possess the ability to functionally act for the benefit of its Members. Key feasibility issues were still unresolved and would take a few to several years to fully address. Specifically, these were the following: uniformity in purpose, the ability to streamline each Members core national interests as it relates to their oil exports and revenues into a collective, organizational strategy, institutional acceptance and recognition in the global economy, and, the most important being efficacy for its Members. In the first two years of its existence, OPEC managed to establish its internal decision-making bodies, its statutes, policies and procedures, and at least in theory, a collective policy to formulate a regulation of production and an approach towards negotiations with the IOCs (See Table 1). This was sketched out in its Resolutions I-II.16.

However, even as the institution was making headway to put in place the ability to act for its members, as it is was slowly gaining some international recognition, the issues that the producing countries had with the IOCs still remain unresolved. And as previously mentioned, the economic and political circumstances in some Member states were only getting worse because of continued and expanded budgetary constraints on the respective governments. By far, the most acrimonious struggle between a host producing country and the IOCs in the early OPEC years was in Iraq. After several months of arduous negotiations to find a new mutually acceptable profit sharing arrangement between the Iraqi Petroleum Company (IPC), the consortium umbrella involving the major firms within the country, and the State of Iraq, the post-monarchial Qassim government chose to dramatically escalate tensions with the passage of Public Law 80 in 1961. This legislation, with virtually no consultation with the IOCs, allowed the Iraqi 
government to recover $99.5 \%$ of the land granted to the IPC under former concession agreements. This portion of the concessions was held by the IPC but the consortium either was not actively pursuing upstream activities or had indefinitely delayed them. Again, given the oil glut in the 1960s, there was little incentive for the consortium to bring new supplies in an already saturated market. The Baghdad government, however, saw things differently. It was not unusual for many producing countries in the developing world, the overwhelming majority of which depended upon IOCs to export their crude, to view market conditions as wholly manipulated by the IOCs, when in fact the new conditions of the day (i.e. the entrance of Soviet and independent firm crude) limited the consortium's options.

The only areas left untouched by the Baghdad government was the $.5 \%$ of Iraqi land where the consortium was already extracting crude. With this legislation, the Iraqi National Oil Company (INOC) also came into existence, as the Baghdad thought that possibly new, more advantageous deals could be made with independents or even the USSR - partnership with the newly minted INOC. Nevertheless, this move by the Qassim government had serious ramifications, both for the future of Iraq but also for OPEC. As Fadhil Chalabi has argued, Iraq's actions (which were tantamount to nationalization) not only severally curtailed activities in Iraq, but also greatly benefited Iran and Saudi Arabia. ${ }^{209}$ And even after Qassim's downfall, the continuing dispute between the central Baghdad government and the IPC concession holders over the nature of the profit sharing survived. So much so that the US government cautioned US firms in seeking concession in areas taken over by the Baghdad government under Public Law 80. Washington feared

${ }^{209}$ Chalabi, Oil Policies, Oil Myths: Analysis and Memoir of an Opec 'Insider', 77-80. 
that if a few US firms would simply accept the new arrangements, and thus cut separate deals with Baghdad, the outcome would be perceived as a forced imposition upon concession holders. This, they worried, would have wider implications for other concession agreements. In a telegram from Washington to the American embassy in Baghdad a year after the Ramadan Revolution, the US thinking was that "if other companies should bid for concessions without a prior settlement, GOI [Government of Iraq] will have good reason to suppose that concession agreements can be terminated unilaterally and replaced with contracts with other oil companies under conditions dictated by GOI wherever GOI considers that it is in its own interest to do so." ${ }^{210}$ Thus, they concluded that other producers could utilize this event as a template, which not only would affect OPEC Members but the wider industry of the day. What was a particular concern to the US was what producing governments would make of this precedent, which would lead them to believe that American firms "are not concerned for legal rights of others and are motivated solely by advantages to be derived from access to additional oil resources and new profits." 211 Thus what the US did was to privately dissuade American firms from reaching individual settlements with Baghdad (without a resolution to the Public Law 80) while undertaking efforts with non-US firms of entering into Iraq while the issue remained unresolved. ${ }^{212}$ More so, this was done with the explicit knowledge that American firms, for the time being, would suffer loss and access to foreign firms. Yet for Washington, what they referred to as the "disadvantage of [a] completely passive

\footnotetext{
${ }^{210}$ Telegram From the Department of State to the Embassy in Iraq, 13, April 1964, FRUS, Volume XXXIV, Energy Diplomacy and Global Issues, Document 179.

${ }^{211}$ Ibid

${ }^{212}$ Ibid
} 
attitude" by the US government would justify the "risk of possible lost opportunities to American firms." 213

Nevertheless, the Iraq experience, as Fadhil Chalabi has asserted, proved to be a template for OPEC in the later years when collective negotiations with the companies were to take place. ${ }^{214}$ But at the time, it was a clear example that while the Organization had overcome the skepticism of many more powerful global actors, and had made headway on establishing itself, it still lacked the ability to fundamentally impact current imbalance of power between producers and the IOCs and protect its Members' interests. As negotiations between Iraq and the consortium had reached an impasse, all the Organization could do was "express concern" and issue Resolution III.18, which explicitly supported Iraq's position, but "urged foreign oil companies operating in the territories of its Member Countries to realize that a spirit of true understanding between them and the Member Countries is indispensable to securing...healthy conditions in the world oil industry." ${ }^{215}$ Up until Qassim's ouster by the Baathist-Nasserite coalition in Iraq, production in Iraq stagnated, while those of other Members steadily rose. But even after the Ramadan Revolution, the continuing dispute between the IPC and Baghdad severally eroded Iraq's production potential for the rest of the decade.

\footnotetext{
${ }^{213}$ Ibid

${ }^{214}$ Chalabi, Oil Policies, Oil Myths: Analysis and Memoir of an Opec 'Insider', 44-45.

${ }^{215}$ OPEC, Opec Official Resolutions and Press Releases 1960-1990, 12.
} 
I: Announced first collective action of Member states as a unitary Group. Pledge to formulate system to ensure the stabilization of prices by the regulation of production. Collective protection of members, if as a result of application of any unanimous decision of OPEC any sanctions are employed. No other Member shall accept any offer of a beneficial treatment.

I.2: Countries represented in Conference are original Members of OPEC. Invitation for any country with a substantial net export of crude petroleum can become a new Member if unanimously accepted by all five original Members of the Organization. Pledge to establish regular meeting and organs of OPEC.

II.5: The Creation of the Board of Governors, of which each Member will nominate one Governor. II.6: The Creation of the Statutes: OPEC having two organs, the Conference and the Board of Governors. The development of the departments of these two organs, mechanism of decision-making and authority, rules, and meeting intervals.

II.7: "President of Conference" Title created. "Chairman of the Conference" title abolished.

II.8: Financial Requirements for the Organizations and Membership dues established.

$\bar{\Xi} \quad$ II.9: Conference appoints Fuad Rouhani as First Chairman of the Board of Governors.

II.10: Headquarters established at Geneva, Switzerland.

II.11: Board of Governors commissions study on the economics of investment in the oil industry by concession holding companies, in comparison with investment in other enterprises in different countries. II.12: Members shall compile and send to the Board of Governors, a statement concerning its position in the matter of determination of prices at which exporting companies, and also concerning the appropriate procedure in regard to the settlement of disputes arising on that matter pay for its petroleum.

II.13: Board of Governors commissions study on a 'just pricing formula, supported by a study of international proration', of crude oil in the global economy.

II.14: Conference attempts to coordinate crude import measures with friendly countries that have placed import quotas 'in order to protect their domestic crude production... in order to arrive at satisfactory solution and thus promote mutual understanding for the protection of the interests of both exporting and importing countries.'

II.16: Statement of support for individual Members in current negotiations with the IOCs. OPEC expressed hope that IOCs concerned will 'meet such discussions in a spirit of understanding and will ensure their prompt and satisfactory conclusion.'

III.18: Expression of concern regarding Iraq-IOC negotiations.

$\checkmark \quad$ III.19: The Creation of an Information Center in the Secretariat for compilation and distribution of industry news and research.

III.20: Review of the Venezuelan Delegation's Coordinating Commission for the Conservation and Commerce of Hydrocarbons, particularly in preventing the weakening of crude oil prices. Considers similar measures of control may prove beneficial to other Members

IIII.26: Conference directs Board of Governors to conduct uniformity study to better functionality of Organization

III.27: Reaffirmation of Resolution I.

III.28: Claims that 'information submitted by Venezuela that crude oil produced in Member Countries and elsewhere has been utilized by some oil companies and oil agencies to weaken the price structure, resolves that Members conduct a thorough investigation of this matter and directs the Secretariat to study the findings.

IV.32: First call by OPEC for Members to enter into negotiations with the IOCs to ensure payment on the basis of posted prices not lower than those of 8/1960. That Members formulate a rational price structure to guide future price policy. price structure to be devised will be the linking of crude-oil prices to an index of prices of goods which the Member Countries need to import.

IV.33: That each Member Country should approach the company or companies within their countries with a view to working out a formula where under royalty payments shall be fixed at a uniform rate which Members consider equitable, and shall not be treated as a credit against income-tax liability.

IV.34: Member Countries should take measures to eliminate any contribution to the marketing expenses of the IOCs within their territories

IV.35: Recommendation that Member Countries create of a body entrusted with fulfilling functions similar to Venezuelan Coordinating Commission 
At OPEC's $4^{\text {th }}$ Conference in Geneva in 1962, the first session being in April while the second session was in June, the Organization took a markedly different approach to the negotiations than they had in the past. While previously OPEC had taken a back seat to Member states talks with the IOCs, the Organization gradually chose to become institutionally invested in the outcome of the negotiations. During the $4^{\text {th }}$ Conference, OPEC decided to formally enter into the negotiations by calling its Members to fully engage the IOCs to restore the crude oil price prior to August 1960, (Resolution IV.32). Furthermore, possibly knowing that the price reduction may have now become fixed (at least for the time being), OPEC went further. In Resolution IV.33, OPEC laid out its basis for a uniform royalty payment to all Members - apart from the taxes that the IOCs were giving to the Members. OPEC's rationale, again contained in the Resolution, was that "under the arrangements at present in force between the Member Countries and the oil companies...no compensation is paid for the intrinsic value of petroleum, royalty or stated payment commitments being treated as credits against income-tax liabilities... and that the right to receive compensation for the intrinsic value of petroleum" to OPEC's Members is "incontestable". 216

Furthermore, in Resolution IV.34, the Organization demanded of its Members that they should "take measures to eliminate any contribution to the marketing expenses of the companies concerned." ${ }^{217}$ In other words, because producing countries did not participate in the any of the marketing operations of the oil companies, and thus did not benefit, they should not be held responsible for costs accrued with such activities.

\footnotetext{
${ }^{216}$ Ibid., 17.

${ }^{217}$ Ibid., 18.
} 
Needless to say, the response by the IOCs and especially the home governments showed a new sense of anxiety about OPEC. In its previous statements and resolutions, OPEC had come out in defense for its Members position, but this new activist approach of collectively trying to change the terms of the profit sharing, uniformly - which would set a major precedent for other producers, whether they be Members or not - was alarming the companies. In the most detailed analysis of the negotiations between the IOCs and OPEC Members to date, Ian Skeet laid out what was at stake for both sides. In implementing a uniform royalty expense (a charge that Venezuela was already doing but would now apply to all Members), OPEC would be essentially adding 11 cents to their profit share, per barrel of oil. ${ }^{218}$ As mentioned earlier, the posted price of crude at the time was $\$ 1.80$, which would amount to be a $6 \%$ charge for the IOCs. And had such a precedent become the industry norm for dealing with other non-OPEC producers, the financial impact to the major consortium participants would be substantial.

However, far from OPEC inter-Member discussions and the negotiations between Member states and the IOCs was the important role of the US. It is here where the importance of American influential capability on certain Members, exhibited through economic and military assistance, clearly becomes evident. Only days after the 4th Conference, the Iranian government privately confirmed to the US that though OPEC had adopted these particular resolutions, the Iranian government's support for them "in no way implied [an] attack on [the] oil consortium or suggestion [that the] oil agreement should be modified." ${ }^{219}$ The Iranians told the US Embassy in Tehran that the designation

\footnotetext{
${ }^{218}$ Skeet, Opec: Twenty-Fve Years of Prices and Politics, 27.

${ }^{219}$ Telegram From the Embassy in Iran to the Department of State, 2 July 1962 , Foreign Relations of the
} 
of Iran and Saudi Arabia to spearhead the negotiations with the IOCs was "ensuring [a] moderate approach", claiming that the "negotiations need not be completed within [a] specified time and that they would be conducted in unhurried and friendly spirit." 220 Though the American's seemed encouraged by the Iranian position, they still remained concerned about what they felt was the "fundamental and far-reaching character of resolutions", chiefly the "sharp impact on member companies of [the] oil consortium as well as other segments of international oil industry." 221

In a closed session meeting between officials from the US State Department and Leroy Stinebower and George Pearcy from Standard Oil of New Jersey, the concerns over the new OPEC Resolutions were clearly visible. Although Jersey's executives were confidant in the negotiating strength of the IOCs, they also feared mass governmental expropriations that in their mind had "no rational counterforce" to them. ${ }^{222}$ Recognizing the seriousness of the new OPEC stipulations, the US government could not afford to sit on the sidelines. However, in its discussions with its European partners, the US stated that "it prefers to avoid adding to OPEC's international prestige or position" and thus "contacts between OPEC and other organizations, including [the] EEC (European Economic Community, the forerunner to the European Union), [should] be avoided or minimized." 223 Additionally, in consultations with the British, both the US and the UK

United States, 1961-1963 Volume IX, Foreign Economic Policy, Document 354

${ }^{220}$ Ibid.

${ }^{221}$ Ibid.

${ }^{222}$ Memorandum of Conversation, 20 July 1962, Foreign Relations of the United States, 1961-1963

Volume IX, Foreign Economic Policy, Document 355

${ }^{223}$ Circular Airgram From the Department of State to the Mission to the European Communities, 14 November 1962, Foreign Relations of the United States, 1961-1963 Volume IX, Foreign Economic Policy, 
agreed on this position as well. For both, there emerged a "complete unanimity" on the "attitude which both governments should take towards OPEC....[agreeing] ...that it would not be to their mutual interests to undertake discussions with OPEC member governments nor with the Organization itself on OPEC matters and that efforts to involve the US and UK governments in OPEC negotiations with the oil companies should be resisted." ${ }^{224}$ However, as with the US position towards OPEC during the creation of the Organization, Washington and London agreed on avoiding any semblance of hostility towards the Organization, ${ }^{225}$ as that might create unforeseen consequences, particularly in the Cold War context with the USSR.

Throughout 1963, OPEC, led by Secretary General Rouhani, engaged in both direct and indirect talks with the Consortium, all in the background of the Organization's continuing development and with constant consultation with the Members. Yet, in November of 1963 , just prior to the $5^{\text {th }}$ OPEC Conference in Riyadh in late December, the representatives of the Consortiums within the Member states replied with a counter offer to OPEC's Resolution IV.33, concerning uniform royalty payments. The IOCs offered 3.5 cents per barrel revenue increase, which OPEC under Rouhani immediately dismissed. ${ }^{226}$ Rouhani had confidence that this was the official position of all Member states, and thus OPEC's collective position. However, on December 6, 1963, in a State

\footnotetext{
Document 361

${ }^{224}$ Memorandum From the Deputy Director of the Office of Near Eastern Affairs (Davies) to the Assistant Secretary of State for Near Eastern and South Asian Affairs (Talbot), 5 July 1963, Foreign Relations of the United States, 1961-1963 Volume XVIII, Near East, 1962-1963, Document 291

${ }^{225}$ Ibid.

${ }^{226}$ Ian Skeet, Opec: Twenty-Five Years of Prices and Politics (Cambridge University Press, 1991), 31.
} 
Department meeting with some of the heads of the major IOCs, it was revealed that there was a surreptitious effort to break the OPEC consensus on royalty payments.

The participants were the following: G. L. Parkhurst (Vice President and Director of Standard Oil Company of California and a Director of Arabian American Oil Co.) William F. Bramstedt (Vice President of Standard Oil Company of California) John Noble (Vice President of Texaco, Inc. and Director of Arabian American Oil Co.), Howard Page (Director and Vice President of Standard Oil Co. of New Jersey and a Director of Arabian American Oil Co.) Henry C. Moses (Executive Vice President of Middle East Concessionary Interests, Socony Mobil Oil Co. and a Director of Arabian American Oil Co.), Garry Owen (Director and Vice President of Arabian American Oil Co.), Grady Davis (Vice President of Gulf Oil Co) and Kermit Roosevelt (Vice President, Gulf Oil Co.). At the meeting, Howard Page of Jersey revealed that British Petroleum executives had recently received a rejection by OPEC's Rouhani and that in light of this, the upcoming OPEC meeting in Riyadh could possibly witness the Organization using sanctions against the IOCs. ${ }^{227}$ However, Kermit Roosevelt from Gulf Oil differed with his assessment. Roosevelt stated in this private meeting that he had recently spent time with the Shah of Iran and that the Iranian Monarch understands why the offer that was made to Rouhani "was the maximum which the companies can make". ${ }^{228}$ Roosevelt's history with both Iran and the Shah was quite unique, for a decade prior, it was this same Roosevelt, at the time a CIA agent in Iran, who headed and implemented Operation

\footnotetext{
${ }^{227}$ Memorandum of Conversation, 6 December 1963, Foreign Relations of the United States, 1961-1963 Volume XVIII, Near East, 1962-1963, Document 381

${ }^{228}$ Ibid.
} 
AJAX which led to the coup against Mossadegh and the restoration of the Pahlavi family to the Iranian throne. Both men had remained close since that consequential event. And though some US officials, even as late as a week prior to OPEC's Riyadh meeting in late December of 1963, feared either sanctions or 'arbitrary Member government action' against the IOCs, when the time came, Roosevelt's confidence proved prescient. ${ }^{229}$

As the $5^{\text {th }}$ Conference commenced, it became clear to other Members that the Shah had changed Iran's rejection of the IOCs offer and had firmly refused to go along with sanctioning the Consortiums . Though not identical, the Saudi position was also similar, but it was clear that the Shah was leading the sudden opposition of what was supposed to be collective punitive action against the IOCs. While senior industry experts, such as Ian Skeet, surmised that the Shah's sudden shift was due to suspicions regarding other Members' intentions or even pressure from the National Iranian Oil Company, ${ }^{230}$ in the years since US archives have become declassified, the extent of US intervention, albeit indirect, into the OPEC decision-making process of that time has become more apparent. What came out of the Riyadh meeting was a fundamental shift in how OPEC would continue to negotiate with the IOCs. Resolution V.40 pledged to continue negotiations, by way of a Committee consisting of Fuad Rouhani, Iraq's Abdul Rahman Bazzaz, and Saudi Arabia's Hisham Nazer. ${ }^{231}$ Moreover, OPEC explicitly stated that this group would negotiate on the Organization's behalf with the oil companies - for the first time, as a collective entity, as opposed to OPEC overseeing several different negotiations

\footnotetext{
${ }^{229}$ Memorandum From the Assistant Secretary of State for Near Eastern and South Asian Affairs (Talbot) to Acting Secretary of State Ball, 16 December 1963. FRUS

${ }^{230}$ Skeet, Opec: Twenty-Fve Years of Prices and Politics, 31-32.

${ }^{231}$ OPEC, Opec Official Resolutions and Press Releases 1960-1990, 20.
} 
happening simultaneously. The IOCs feared this particular outcome, became some of them thought that if OPEC negotiates as a unitary institution (with these three individuals leading the effort) as opposed to "representatives of the individual producing governments... the next step could be to exclude the companies as bargaining agents in favor of governments." 232

Notwithstanding, the IOCs' fear did not materialize in the immediate aftermath of the committee's appointment. Much of this had to do with Iran's moderation role in the negotiation process with the IOC's. In March of 1964, only four months before OPEC's $6^{\text {th }}$ Conference in Geneva, the assessment of Iran's role was clear to the US: "Iran has been successful so far in forestalling unilateral actions by the Organization of Petroleum Exporting Countries against the oil companies." ${ }^{233}$ However, this came at a major cost to Iran's reputation within the Organization. Immediately after the Iranian change of position, on the eve of the $5^{\text {th }}$ Conference, OPEC's first Secretary General, the Iranian Rouhani, was no longer able to carry on his role as opposition from Iraq and other unilateralist Members grew. Moreover, in April of 1964, it was the US assessment that a possible Arab backlash against the Shah could very well take place, leading to the expulsion of Iran from OPEC. ${ }^{234}$ The only reason given why the unilateralist camp tolerated Iran was because OPEC's foundational principle was based upon strength in

\footnotetext{
${ }^{232}$ Memorandum of Conversation, 29 January 1964, Foreign Relations of the United States, 1964-1968 Volume XXXIV, Energy Diplomacy and Global Issues, Document 176

${ }^{233}$ Memorandum From the Acting Assistant Secretary of State for Near Eastern and South Asian Affairs (Jernegan) to the Special Group (Counter Insurgency) 2 March 1964, Foreign Relations of the United States, 1964-1968, Volume XXII, Iran, Document 6

${ }^{234}$ Telegram From the Embassy in Saudi Arabia to the Department of State, 12 April 1964, Foreign Relations of the United States, 1964-1968, Volume XXXIV, Energy Diplomacy and Global Issues, Document 178
} 
numbers, and had a major producer left the Organization in its developmental phase, the longevity of the OPEC enterprise would be in doubt. ${ }^{235}$

During its $6^{\text {th }}$ Conference in Geneva, OPEC passed Resolution VI.47, which acknowledged that the IOCs did send a revised offer to the Organization (of which was only marginally better than that which Rouhani, on behalf of the Group rejected). While not accepting the offer, the Organization stated that it was a "suitable basis" to continue to find a permanent agreement. And in the $7^{\text {th }}$ Conference months later, OPEC's Resolution VII.49, claimed that five Members (Iran, Kuwait, Qatar, Libya, and Saudi Arabia) accepted the latest offer by the IOCs (again only a marginal increase of the prior offers), while Iraq rejected the offer, and Venezuela and Indonesia remained critical of the offer. ${ }^{236}$ Moreover, the Organization stated in VII.49 that because five of its Members did accept the offer, each Member should decide acceptance or rejection of the Consortiums ' new proposal individually. But as negotiations would proceed, this dynamic, and the roles that each country within OPEC would play, would fundamentally change.

\section{Collective Negotiations with the IOCs}

Whatever positive fiscal contribution the royalty payment fight gave to OPEC Members, ${ }^{237}$ it paled into comparison with the looming economic and security dilemmas that were all the more exacerbated by stagnated crude prices and creeping non-OPEC competition.

\footnotetext{
235 Ibid.

${ }^{236}$ OPEC, Opec Official Resolutions and Press Releases 1960-1990, 25-28.

${ }^{237}$ Robert Mabro, "On Oil Price Concepts," (Oxford Institute for Energy Studies, 1984), 7-11.
} 
The posted price of crude remained $\$ 1.80$ from $1960-1971 .{ }^{238}$ After an uneventful $8^{\text {th }}$ Conference, OPEC met in Tripoli in July of 1965 with a plan to "adopt as a transitory measure a production plan calling for rational increases in production from the OPEC area" to meet the estimated increase in world demand. ${ }^{239}$ There were, however, three main problems with this approach. Firstly, the IOCs still possessed production control over the OPEC area, despite the increasing technical efficiency of OPEC NOCs. The second problem was discipline among Members. For this 'soft' pro-rationing to work (although OPEC did not view this plan in those terms), there needed to be strict guidelines on how much each Member could produce (or under-produce), in order for prices to gradually rise again. And finally, the production from the non-OPEC area was simply too great to counter.

Besides OPEC's support for the passage of a peculiar law by the Libyan government implemented, via Royal Decree, that among other things made much more headway on royalty payments than the actual Organization had done, OPEC's $10^{\text {th }}$ Conference in December of 1965 did not address the fundamentals of the Member's dilemma with the IOCs. Yet roughly at the same time, there was progress in another area: a marked shift in both the US, and by extension, the Western approach to OPEC. From late 1965 to early 1966, the US was in discussion, both internally, and with its allies, on the need to have more of an activist position regarding the Organization. Ever since OPEC's $5^{\text {th }}$ Conference, there had been an impasse on how to move forward with sustainable resolution on profit sharing. The market conditions not only had matters

\footnotetext{
${ }^{238}$ See: http://www.bp.com/sectionbodycopy.do?categoryId=7500\&contentId=7068481 (accessed December 15, 2012).

${ }^{239}$ OPEC, Opec Official Resolutions and Press Releases 1960-1990, 44.
} 
worse, but by this time, there had been criticism of the lack of movement by all Members of the Organization. The American reasoning was summed up in a State Department communiqué to the US Embassy in Vienna, OPEC's Headquarters:

The US-UK policy of neutrality and non-commitment towards OPEC ... has not prevented the OPEC from obtaining recognition from international organizations, specifically the ECOSOC and UNCTAD, and Austria has granted diplomatic status to the organization and its personnel. In light of these and other successes by the OPEC, the USG intends to review the present policy towards the OPEC and consider if some other policy towards the organization might more usefully serve U.S. interests. ${ }^{240}$

The US policy officially changed to active engagement in March of 1966, making it possible, for the first time, for US officials to officially meet with the OPEC Secretariat and to develop a working relationship with the Group. ${ }^{241}$ The practical benefit of this new approach was that the US no longer needed to rely on OPEC Member States or Consortium partners for insights on how the Organization functioned. Moreover, in stepping out of the shadows, the American perception was that with the US possibly midwifing negotiations, there was a much higher chance that a mutually beneficial resolution to the pricing and profit sharing dispute could be reached.

However, the American action came far too late, for by the time they entered, in an official capacity, the moribund negotiations, other trends had already taken a life of their own. The US knew that some Members of OPEC, namely Iraq, Venezuela, and Libya, had serious misgiving about any foreign enterprise controlling the oil industries in

\footnotetext{
${ }^{240}$ Circular Airgram From the Department of State to the Embassy in Austria, 24 November 1965, Foreign Relations of the United States, 1964-1968, Volume XXXIV, Energy Diplomacy and Global Issues, Document 185.

${ }^{241}$ Airgram From the Embassy in Kuwait to the Department of State, 14 March 1966, Foreign Relations of the United States, 1964-1968, Volume XXXIV, Energy Diplomacy and Global Issues, Document 189.
} 
their respective countries. This was brought to light many times by both Consortium members and by officials from these respective countries, in various forums. Moreover, even Indonesia, a major recipient of US aid, was also much more forceful in the advancing of a wholesale revision of the profit sharing arrangement than what was publicly known. However, the first sign that events had progressed into a new phase of OPEC's relations with the Consortium was the change of position in Iran.

The first instance where the US became aware of this changed position was in 1966. As early as January of that year, the Iranian government started airing grievances to both the IOCs and their home governments, particularly the US, on stagnating or decreasing production. ${ }^{242}$ These grievances quickly unearthed many of the Iranian government's frustrations with the concession holders on profit sharing and prices, as the Shah blamed what amounted to a 200,000 barrel per day decline in production to the decreased revenue Iran was witnessing in weeks and months prior. ${ }^{243}$ It was indeed in January of 1966, where the US began to witness the Shah, for the first time, tie his frustration with the IOCs with his strategic partnership with the West overall. At a meeting with the US Director of the Office of Near Eastern Affairs, Armen Meyer, the Shah stated bluntly that "if oil companies do not provide anticipated growth in revenues, Iran might have to reorient [the] 'philosophy' which [the] Shah ...had espoused 'during twenty-five years of [his] reign'.", 244

\footnotetext{
${ }^{242}$ Telegram From the Embassy in Iran to the Department of State, FRUS, 1964-1968, Volume XXXIV, Energy Diplomacy and Global Issues, Document 187.

${ }^{243}$ Telegram From the Embassy in Iran to the Department of State, 20 January 1966, FRUS, 1964-1968, Volume XXXIV, Energy Diplomacy and Global Issues, Document 188.

${ }^{244}$ Ibid.
} 
In subsequent meetings with US officials from, the Shah, much more confident, but more in need of capital for both social spending at home, and particularly on military spending, expressed varying signs of disappointment and frustration regarding the behavior of the Consortium in Iran. ${ }^{245}$ By that time, Members had not focused anymore on royalty payments bringing the extra revenue that they had hoped for, but major producers like the Iranian government, were putting their hopes in expanded production. And though while still high, the Shah's government expressed frustration with American officials that the Consortium was not increasing production, but relegating Iran's status to other smaller producers. The driving force behind the Shah's changing approach to the Consortium, as understood by the US was the following: "a mix of need for money, desire to establish a position in marketing of oil, belief that Iran should be able utilize her own oil assets, and Shah's views that Iran deserves more than its neighboring oil countries, that East-West détente makes him less dependent on West and that Iran should do more to assert independence." ${ }^{246}$ As stated previously, Iran during the 1960s was the largest recipient of US aid, as it geographical positioning made it one of the West's chief allies during the Cold War. As the Shah's Iran occupied such an important place in US strategic thinking against the USSR, US aid, just like American political intervention in Iran in the 1950s, had a geostrategic rationale behind it. But by this time, the aid that the US was providing along with stagnant revenue from the oil output, proved to be insufficient for the exceptional expenses that the Shah's Iran had. Eventually, the Shah's

\footnotetext{
${ }^{245}$ Research Memorandum From the Director of the Bureau of Intelligence and Research (Hughes) to Acting Secretary of State Ball, 3 June 1966, Foreign Relations of the United States, 1964-1968, Volume XXII, Iran, Document 147

${ }^{246}$ Telegram From the Embassy in Iran to the Department of State, 28 October 1966, FRUS, 1964-1968, Volume XXXIV, Energy Diplomacy and Global Issues, Document 192.
} 
monetary concerns would collide with the IOCs strategy, backed by the US, of dealing with the transitioning market conditions and negotiations with OPEC.

As the Shah's grievances against the Consortium gradually came to light, the direction of his anger often increasingly became directed towards US officials. In one of the first acts of open defiance to the US, the Shah threatened to rearrange his arms purchases away from American companies, diversify purchases from Europe. This took back American officials because it presupposed, on the part of Iranian officials that the Consortium in Iran "could have promised greater oil 'offtake' had the US applied pressure on the American companies who are members." ${ }^{247}$ The US feared that by reason of Iran's frustration with the IOCs, the Shah would become more reactionary, both with his relationship to the Consoritum and possibly with the US. ${ }^{248}$ For the rest of the year, the US and the UK, with collaboration the IOCs, made a serious attempt to address the Shah's concerns as it related to oil revenue. However, American policy was explicitly not to become enmeshed in the negotiations so as to perceived in openly taking sides, between Iran, which was main strategic ally, and the Consortium, which mostly were American firms. ${ }^{249}$ The US attempted to reassure the Iranian government the fundamental problem vis-à-vis production volume and prices were the market conditions, and that the IOCS were "sympathetic to Iran's problems". ${ }^{250}$ However, by the end of the year, according to US officials that had consulted with both the IOCs and the Iranian

\footnotetext{
${ }^{247}$ Ibid.

${ }^{248}$ Ibid.

${ }^{249}$ Memorandum of Conversation, 2 November 1966, FRUS, 1964-1968, Volume XXXIV, Energy Diplomacy and Global Issues, Document 193.

${ }^{250}$ Telegram From the Embassy in Iran to the Department of State, 25 October 1966, FRUS, 1964-1968, Volume XXXIV, Energy Diplomacy and Global Issues, Document 191.
} 
government, both sides were on a "collision course" as their positions became increasingly irreconcilable. ${ }^{251}$ Thus, a tentative arrangement on production levels was reached (a proposed 11\% increase in 1967 and 1968), but to be gradually implemented. ${ }^{252}$ Incidentally, Iran's production in 1967, because of the Arab Oil Embargo of that year (which will be touched subsequently), rose to $20 \%$ above 1966 levels. ${ }^{253}$

Yet, by mid-1967, although Iran's production significantly rose, the fundamental problem concerning revenue, primarily because of the saturated market, still remained. During the continued negotiations between Members and the IOCs, the Iranians began taking the position of other Members, even though the Shah felt that Iran's importance, both to the global economy and to the Middle East security architecture, was far more important - and thus deserving of better privileges from the IOCs. Like other OPEC Members, the Iranians also demanded the 6.5\% OPEC discount be eliminated, which would net Iran about 10 cents per barrel of oil, and if the "discount were completely eliminated by January 1968, Iran would get about $\$ 200$ million extra in the next five years." ${ }^{254}$ Above these demands was the Shah's constant insistence that the Consortium increase Iranian production. Yet, the IOCs consistently said that they would be unable to increase Iranian output without cutting back Arab production, which most surely would

\footnotetext{
${ }^{251}$ Memorandum of Conversation, 4 November 1966, FRUS, 1964-1968, Volume XXXIV, Energy Diplomacy and Global Issues, Document 194.

${ }^{252}$ Action Memorandum From the Assistant Secretary of State for Economic Affairs (Solomon) to the Under Secretary of State for Political Affairs (Rostow), 12 October 1967, FRUS, 1964-1968, Volume XXXIV, Energy Diplomacy and Global Issues, Document 194.

${ }^{253}$ Action Memorandum From the Assistant Secretary of State for Economic Affairs (Solomon) to the Under Secretary of State for Political Affairs (Rostow), 11 December 1967, Foreign Relations of the United States, 1964-1968 Volume XXII, Iran, Document 252

${ }^{254}$ Ibid.
} 
provoke additional Arab hostility towards the Consortium. ${ }^{255}$ The new Iran question as it relates to the OPEC negotiations came to a head in December of 1967 in another private meeting with Armen Meyer and the Shah. Meyer reported:

My audience with Shah turned out to be one of most unpleasant of my tour here. He was obviously smoldering over devaluation shortfall issue with which he had been preoccupied earlier in day. Using terms such as "robbery," "thieves" and some unprintable epithets, [the] Shah professed to be completely disgusted with consortium's behavior. At one point in discussion, Shah said if companies wanted war they could have it. This time it would not be with a Mossadegh but with a united Iran behind Shah himself. When I noted consortium believes it has legal basis for its position and perhaps arbitration might be one possibility for solving devaluation problem, Shah said arbitration is totally unacceptable. As for matter being legal issue, Shah said GOI would take care of that once and for all by immediate passage of legislation, which would insure GOI undepreciable payments. ...Shah went on to berate consortium for its continual maltreatment of Iran, despite Iran's exemplary behavior in comparison with other countries. My efforts to point out that Iran has in fact been treated very well fell on deaf ears. Shah once again contended that consortium is sitting astride Iran's vast reserves and he cannot permit such restraining influences on Iran's welfare. I pointed out problem is one of marketing. In this connection, I suggested Iran may be trying to carry water on both shoulders...Shah argued such competition is infinitesimal compared with bonanzas greedy oil companies are throwing to countries like Libya. When I pointed out geographic factor which places Libya in favorable situation with Suez closed, Shah said what really infuriates him is companies' lifting large quantities from sheikhdoms like Kuwait and Abu Dhabi when Iran with its 26,000,000 people needs funds to maintain its progress and play its role in Mideast security. Shah also asserted that Saudi Arabia's production will soon move up to 4,000,000 barrels per day. Since geographic factor a la Libya cannot be applied vis-à-vis Saudi Arabia, this further demonstrates he said, how companies discriminate...Shah once again mentioned possibility of legislation which would enable GOI to have oil at well-head for clients which GOI may develop not in competition with consortium. He noted Iraq had long since found companies submissive to such measures. My natural response was to point to Iraq's sorry plight today and how much better off Iran is. I urged Shah "with every bone in my body" not to go down Iraqi road.... Once again I reminded Shah that GOI's relationship with consortium likely be much more productive if it continues as partnership

${ }^{255}$ Ibid. 
than if it is coercive. Shah readily agreed but said companies seem only interested in great profits and fail to take into account broader issues such as encouraging a country like Iran which is moving in positive direction and which has potential for influencing whole area in constructive way. Before closing discussion, I told Shah I had obviously picked a bad day for my audience. He managed to permit himself a brief smile, but added that on any other day he would feel the same way about the oil companies' behavior vis-à-vis Iran. ${ }^{256}$

By 1968, the Shah had essentially adopted the revisionist position of other OPEC Members, but with more sophistication and without the reactionary behavior of Iraq or later Libya. Thus he was consistently able to obtain short-term concessions from the IOCs while both would agree to work on a longer term solution. In a CIA assessment of 1968, entitled appropriately, The Shah's Increasing Assurance, the US perception of the Iranian monarch and his regime was that it had overcome most, if not all, the postMossadegh threats to his rule. ${ }^{257}$ His main focus now, was buttressing his growing military dominance of the Persian Gulf, securing any qualitative military advantage that he had over his neighbors, balancing any Soviet threats to Iran, and maximizing oil revenue. ${ }^{258}$ And because there was no alternative seen to his rule, and more importantly, his pro-Western disposition, the US approach to the newly confident Shah was to make the best of the situation. In a personal conversation with former State Department official, William R. Polk, the Shah was frank about asserting his independence, openly admitting

\footnotetext{
${ }^{256}$ Telegram From the Embassy in Iran to the Department of State, 29 December 1967, FRUS, 1964-1968, Volume XXXIV, Energy Diplomacy and Global Issues, Document 255.

${ }^{257}$ Central Intelligence Agency, Office of National Estimates, 7 May 1968, Special Memorandum No. 9-68. ${ }^{258}$ Ibid.
} 
that while he was once "a puppet", the West now needs him in the Cold War struggle against the Soviets. ${ }^{259}$

Events in other areas in OPEC also seemed to progress more rapidly than both the Consortiums and the US had previously thought. In OPEC's $11^{\text {th }}$ conference, the Organization passed Resolution XI.72, which mandated that Members should enforce "that no petroleum rights be granted or contracts entered into concerning the exploration or exploitation of new areas by Member Countries unless royalty payments and income tax liabilities are calculated on the basis of posted or reference prices." ${ }^{260}$ What the Organization was doing was ensuring that while they could not retroactively enforce a royalty payment they found acceptable, they could stipulate a new royalty payment based upon new contracts. IOCs took this with much concern, because while the market was saturated at that time, there was no guarantee that the market conditions would remain the same - and they did not.

Subsequent OPEC Conferences, particularly the $13^{\text {th }}$ Conference in Vienna in 1967, further provided support for the Iraqi and Libyan positions vis-à-vis the negotiations with the Consortiums, as the issue of production sharing with OPEC Member NOCs had become a critical issue in securing more profit for producers. After the $14^{\text {th }}$ and $15^{\text {th }}$ Conferences, another new factor developed in late 1967 -early 1968 , with the creation of the Organization of Arab Petroleum Exporting Countries (OAPEC). ${ }^{261}$

\footnotetext{
${ }^{259}$ Memo of conversation between William R. Polk and the Shah of Iran re problems in the Middle East, December 1, 1968 [Robert Anderson Papers, Box 158, Standard Oil of Indiana. Dwight D. Eisenhower Library.

260 OPEC, Opec Official Resolutions and Press Releases 1960-1990, 49.

${ }^{261}$ Kuwait. Jan, Saudi Arabia. Jan, and Libya. Jan, Agreement of the Organization of Arab Petroleum Exporting Countries (1968).
} 
The genesis of this Group was initially to gather an Arab voice, not only within OPEC, but also amongst other producing countries on oil related matters. However, with the 6day war between Israel and her Arab neighbors, and the subsequent 1967 Arab Oil embargo, initiated through OAPEC, the West became concerned on possibility of the politicization of oil exports because of producer denial methods - even though the embargo failed. As we will see later, the fruition of this concern in the 1970s dramatically transformed the image of the Organization.

Yet, OPEC Members increasingly became convinced that the road they were on as it related to incremental negotiations with the Consortiums was leading to nowhere. With the principle Western ally having fundamentally altered its position vis-à-vis the Consortiums' role in its oil industry, with OPEC-IOC negotiations deadlocked, while other Members were taking matters into their own hands - either by setting up parallel organizations or attempting to work around Member consensus, the method that the Organization was using for the protection of its Members was clearly failing. In a press release in January of 1968 , OPEC essentially blamed the "failure to reach a reasonable conclusion" on Consortium Members. ${ }^{262}$ Yet, without providing any more details, OPEC retreated back to its 'wait-and-see' posture, which was what many in the West, particularly the IOCs, had grown accustomed to. But something was different this time. Between the $15^{\text {th }}$ and $16^{\text {th }}$ Conferences, there was a flurry of activity among Members. In May of 1968, the Organization held its first Meeting of the Coordination Committee of National Oil Companies of OPEC Member Countries. This meeting, in and of itself, was very important because it shifted the conversation from equitable profit sharing, to inter-

${ }^{262}$ OPEC, Opec Official Resolutions and Press Releases 1960-1990, 59. 
Member coordination on indigenous production efforts. Throughout the entire time between the two Conferences, there was very little new discussion on differing approaches to the impasse from the US, the West, or the IOCs.

When the time came for the $16^{\text {th }}$ Conference, many observers figured that while OPEC would most likely reaffirm a past Resolution for better profit sharing arrangements, or introduce some other type of scheme to obtain additional charges from the IOCs, nothing new would come of it. However, what transpired in that June 1968 meeting would not only forever change the direction of OPEC, which would forge consensus for the years ahead, but would fundamentally end the remaining vestiges of the pre-Cold War oil industry. In a lengthy, technically oriented statement, Resolution XVI.90 introduced the new OPEC policy as it related to its Members: The Declaratory Statement of Petroleum Policy in Member Countries. At the beginning of the Resolution, leaving no room for ambiguity, XVI.90 stated that "Member Governments shall endeavor, as far as feasible, to explore for and develop their hydrocarbon resources directly". Furthermore, as it related to the current relationship that Member States had with the IOCs, XVI.90 acknowledged that the "capital, specialists and the promotion of marketing outlets required for such direct development may be complemented when necessary from alternate sources on a commercial basis." 263

While the rest of the Resolution was more technical in nature, not unlike other OPEC statements, the meaning was simple: OPEC's Member States had officially, but more importantly collectively, declared their intention to nationalize the entire oil industries within their territories - at the same time. The IOCs initially had no response,

${ }^{263}$ Ibid., 62. 
and it would take a few months to glean reaction from the Western governments. The day after XVI.90 was announced, the Consortiums behaved, at least on the surface, as if nothing had happened. And while the announcement was clear, it would take at least two years for the physical ramifications of this new era in the oil industry to come to fruition. Nevertheless, all participants - the producers, the IOCs, the Western governments - knew that something had fundamentally changed. 
CHAPTER III • THE ASCENDANCY PHASE: THE SHIFT OF POWER TO THE PRODUCERS, ORGANIZATIONAL ACTION, AND THE POLITICIZATION OF PETROLEUM, 1969-1979

As OPEC was approaching its second decade of existence, the conditions that led to its formation were beginning to dramatically alter. On every level of analysis - geoeconomics, inter-member relations, the influence of outside powers, and the specific dynamics within individual Member states - the unique circumstances that initially brought the Group together were either no longer existent or beginning the process of evolution. In this era, a new set of circumstances was driving the Organization into unchartered territory vis-à-vis the negotiations with the international oil companies (Companies) and finding its place in the international community.

On a macro level, the changes in the global economy regarding crude oil production and consumption patterns only heightened the importance of the Organization - a carryover from what was already happening after the OPEC's establishment. Within the wider global economy, but more so in the advanced economies of the West, the transition and dependence to crude oil had now been largely completed. This was facilitated by the mass acceptance of the idea that crude oil was and would remain dependably cheap. Although the Companies were the gatekeepers of this concept, having significantly contributed to the development of this paradigm within the advanced economies, near the end of the 1960s they increasingly became aware that both producers and consumers were in a transition period. This was highlighted by the ongoing negotiations with OPEC, specifically OPEC's Solemn Declaration of June 1968, which carried enormous ramifications that eventually affected the entire global oil industry, and 
the wider global economy. But more importantly, leverage was added to OPEC's negotiation strategy with the Companies, while engendering a newfound deference by the major powers towards the Group. Subsequently, this facilitated the marked shift of the US from being overly sympathetic to the Companies to being pushed into the direction of brokering negotiations between the former and OPEC.

From an inter-member perspective, Member states were undergoing a learning curve of not only how to manage an increasingly important international organization, but also how to work with each other vis-à-vis the negotiations and later to institutionalize nationalization of their crude. What was markedly different from the prior era was that the initial years following its creation and engaging in negotiations with the Companies, while attempting to streamline the diversity of viewpoints and strategies that each Member had, OPEC developed a sense of maturity and operational functionality. Not only had they individually learned what was successful or ineffective in their negotiations with the Companies, but also they had begun to understand what it means to be a part of a larger collective effort within the Organization. During this period, Members would defer to policies that benefited the larger Group as opposed to individually based tactical moves that advantaged some states over others. The Companies' early success in halting any major gains by the Organization in the negotiations was primarily a result of the inability of Members to find a collective voice, but more importantly, implement an agreed strategy. Disunity among such a varied Group was natural, but for so long, it debilitated any real movement, up until the end of the Infancy period. It was only with the Solemn Declaration that signs of real, tangible unity began to take shape, only to be operationally expanded in the Ascendancy Phase. 
Subsequently, this facilitated the marked shift of the US from being overly sympathetic to the Companies to attempting to broker negotiations between the former and OPEC. A complicating factor to what had transpired early in the negotiations was how much of American sympathy and her allies lay with the Companies. But as they realized that the increasingly untenable position of ignoring OPEC needed adjustment, they gradually became invested in the negotiations and ultimately played a public facilitating role in the OPEC-Companies negotiations, specifically in the immediate aftermath of the Solemn Declaration. Yet, with the gradual shift that occurred in US strategic thinking to a more measured and balanced approach between OPEC and the Companies, space was created by the Organization for fundamental gains in negotiations. The changing nature of the global economy, consumption trends, and gradual price increase in the 1970s would ultimately create the circumstances where the Organization could, and did, inflict pressure at the negotiating table. And much of this politicization would be witnessed particularly by the Arab producing states (OAPEC) when oil export policy would turn into a weapon against the West in the aftermath of the Yom Kippur war of 1973. Nevertheless, as power shifted to the producers, the long-held suspicions among certain Member states concerning each other would become entangled in how outside actors dealt with both the rising power of OPEC in the international system and the rising costs of crude. The natural rivalries within the Organization and the infusion of great powers into inter-member dynamics would have profound ramifications on not just those two levels of analysis, but also the domestic picture.

This would eventually lead to how the Ascendancy period in OPEC's institutional life would end, at least in part, by what would transpire in the domestic politics of its 
founding Members, particularly at the end of the 1970s. While during the Infancy phase of its development, Members states were able to stabilize the massive economic and security dilemmas they were simultaneously experiencing (in some cases with much help from the infusion of US aid), many of the underlying problems reappeared under a different form. It was in the domestic arena where inter-member suspicions would gradually fuse with outside power involvement in OPEC in order to equalize the balance of power in the Organization, only to have consequential, unforeseen, but lasting consequences for the future of its core founding Member states, the wider Middle East region, and the global economy.

\section{Market Forces}

\section{The changing macro conditions}

Near the end of the 1960s, the decade's oil glut, the resulting cheap crude price, and the continued proliferation of individualized means of transportation had already produced significant behavioral changes regarding oil dependency to the average resident of an advanced economy. And this gradual dependency was not just for transportation purposes, but had spread to several aspects of daily life. As Figure 3.1 shows, as global oil consumption dramatically increased from the mid-1960s to the beginning of the $1970 \mathrm{~s}$, the major drivers of that consumption were the North American and European economies, with Japan's rapidly growing economy, the USSR, and the Eastern bloc playing secondary roles.

However, as the decade closed, consumption patterns would eventually catch up with global production. Most notably, this would eat away at the supply surplus that the USSR, the independent firms, and the major Companies had created only a few years 
earlier. Such was the contradiction of the Companies ' price war against the USSR and the independent firms. Besides creating, albeit indirectly, the conditions where host governments reacted angrily to the decrease in price, thus spurring collective action in forming OPEC, the Companies efforts at regaining lost market share from the USSR and the independents progressively created a dependency effect on cheap crude to consumers in advanced economies. In other words, market share protection efforts not only created anger in producers, but also helped create the expectancy of cheap supply from consumers in the global economy.

Figure 3.1: Crude Oil Prices, 1950-1981 (US dollars per barrel) Source: BP Statistical Review

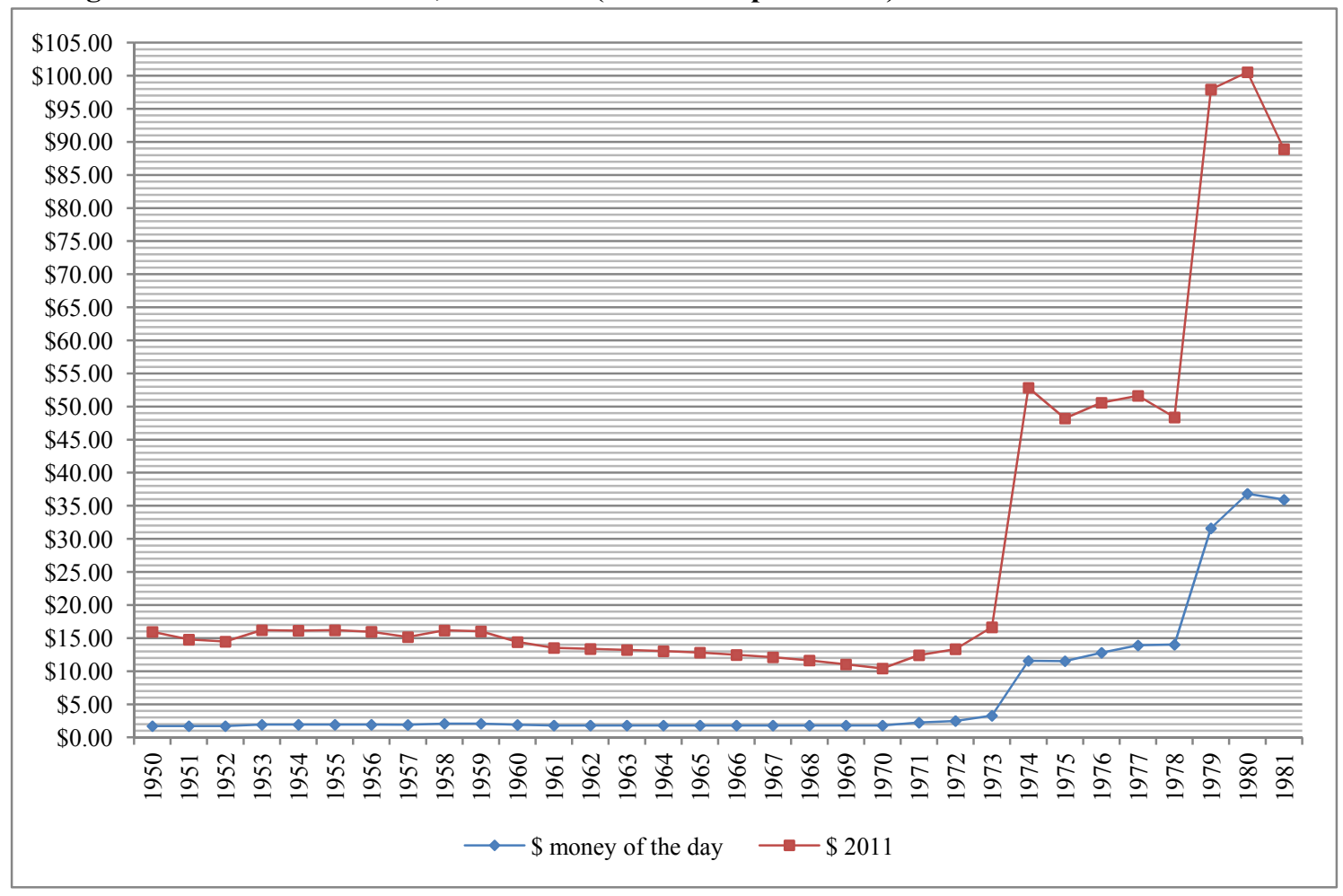


Figure 3.2: Global Oil Consumption by Regions: 1965-1981 (Thousand barrels daily) Source: BP Statistical Review

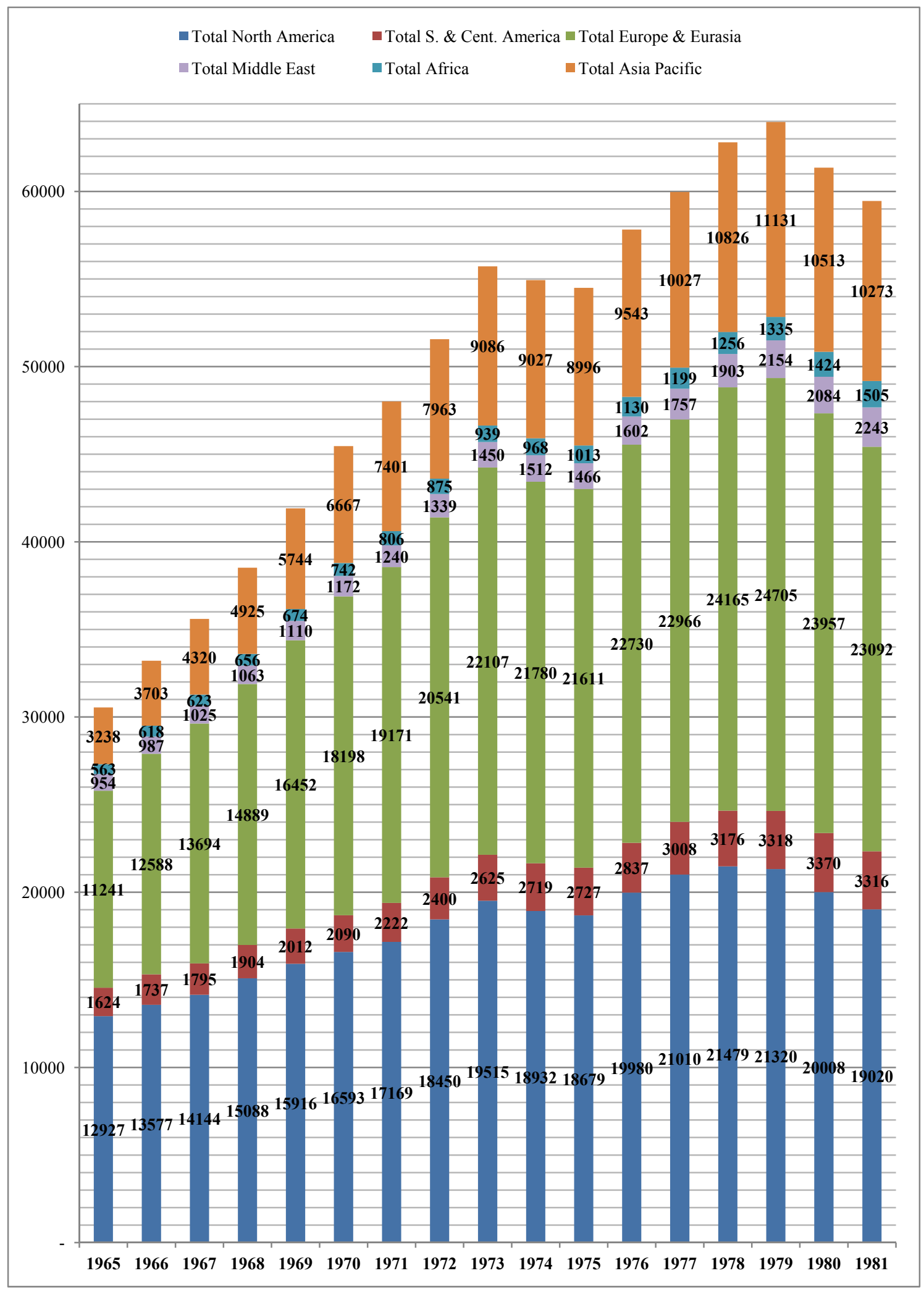


Figure 3.3: OPEC Crude Oil Production by country, as Member States joined the Organization, 1970-1981 (1000 b/d) Source: OPEC Statistical Data. http://www.opec.org/opec_web/en/data_graphs/330.htm

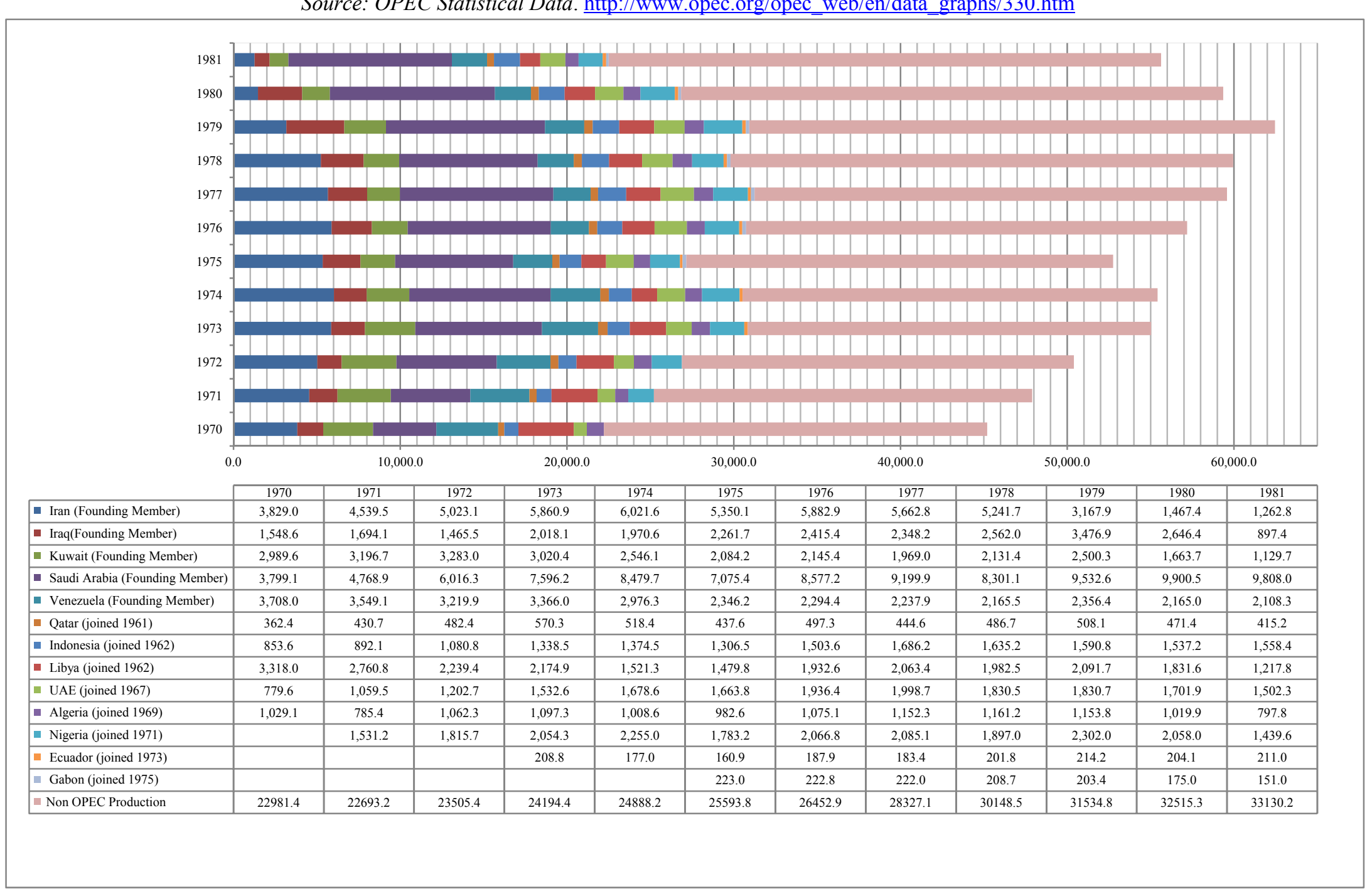


Figure 3.4: Shares of global oil production between OPEC and non OPEC producers: 1960-1981 Source: OPEC Statistical Data. http://www.opec.org/opec_web/en/data graphs/330.htm

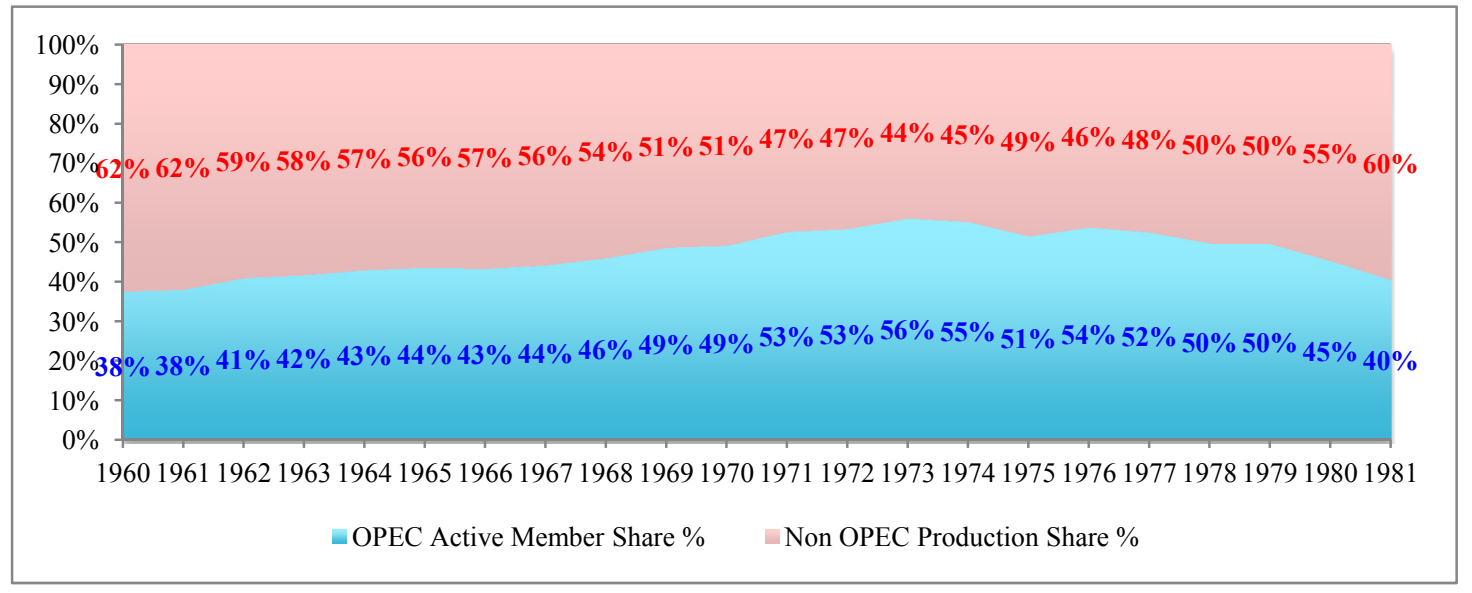

It was this very dynamic that created the conditions for the painful adjustment to rising prices, most notably felt during the oil shocks of 1973 and 1980 (see Figure 3.1). Even before OPEC and its Members (both collectively and individually) began exacting control over their crude export policies and prices as the 1970s began, the enticement of cheap prices leading to more consumption, created a tightening of the market. Thus, when in 1970, Libya's Muammar Ghaddafi's began a forced a price rearrangement on foreign firms operating in his country, ${ }^{264}$ contributing to an export decrease of more than $500,000 \mathrm{~b} / \mathrm{d}$ for that year, the market immediately reacted. The long established price of crude oil per barrel, which since 1961 was $\$ 1.80$ (\$10.42 in 2011 figures) increased to \$2.24 (\$12.43) in 1971 (See Figure 3.2). By 1973, as the Yom Kippur war approached, and the fallout from that conflict, specifically the Arab oil embargo against the nations that supported Israel, ${ }^{265}$ global oil consumption had literally doubled from the prior ten

\footnotetext{
${ }^{264}$ Nicholas Hagger, The Libyan Revolution: Its Origins and Legacy: A Memoir and Assessment (O Books, 2009), 93-110; Yergin, The Prize: The Epic Quest for Oil, Money, \& Power, 577-82.

${ }^{265}$ A. Rabinovich, The Yom Kippur War: The Epic Encounter That Transformed the Middle East (Knopf Doubleday Publishing Group, 2007).
} 
years. Moreover, what exacerbated both the dependency that advanced economies had on cheap crude oil and the growing consumption patterns, was that by the time the Arab oil embargo arrived in late 1973 , roughly $56 \%$ of global oil production originated from OPEC countries. This in turn, meant that the Arab states of OPEC, by 1973, contributed almost $37 \%$ of global oil production - of which was denied to the supporters of Israel during the embargo. And so, the convergence of these seemingly disconnected factors is what led to price of oil being almost quadrupled from 1973's price of $\$ 3.29$ (\$16.66 in 2011 figures) to $\$ 11.58$ (\$52.58) in 1974, which became a constant fixture of the global economy throughout the 1970s until the next oil shock of 1979.

Throughout the 1970s, as economics merged with the politicization of oil production and export policies, the price of crude, long a domain of the Companies, shifted to producing countries, of which OPEC was the main driving force. As nationalization began to be institutionalized - both individually, according to the unique circumstances of the particular Member state, and collectively through OPEC - the Companies began to realize that the traditional mechanisms that allowed their control of crude oil prices were now eroding. The fundamental incapacity of the majors oil firms to halt or reverse collective appropriations by OPEC (although by no means was each Member State's case uniform) introduced a new sense of volatility to the global oil market. OPEC's previous motivation of price defense, of which was the central reason why the Organization was formed, had now largely been achieved. No longer would foreign firms control export volume and subsequently price. But as power shifted to the producers, the policy of price reversal, only to be followed and later replaced by price increases, gradually became the mantra and the central driving force of Organization. 
And as the reasons for this dynamic were not purely economic, later to be mostly political, as a result, there came about significant short-term and long-term ramifications to OPEC's changed strategy.

Regarding the short-term ramifications, the major producing countries tactically responded to the market conditions by utilizing oil export policies (i.e. reductions and redirections of oil production and exports) for fast-tracking revenue accumulation. This was done to not only alleviate any remaining domestic economic shortcomings that they had in the 1960s, when many of them relied on US aid, but more so to modernize their economies, and in the case of Iran and Saudi Arabia, to strengthen their respective conventional military power. As the Arab states of OPEC, under the OAPEC umbrella, politicized exports via embargoes, in retaliation for Western support for Israel in the 6day War and in the Yom Kippur War, the power of the oil weapon became infused with this new revenue accumulation strategy. Hence, the result was that the OPEC, as a force in the international economy, turned into a price maximizer; i.e. attempting to get as much revenue for its Member's oil exports as possible, which was an evolution from its founding principle of price defense. This strategy was reinforced by the conventional, but ultimately inaccurate, belief in the global economy of that time that crude oil reserves globally were becoming exhaustible, thus justifying OPEC's collective demand for higher prices.

This tactical policy, by default, had significant long-term ramifications for the global oil industry and the global economy. The first was that it eventually drove many of the advanced economies, chiefly those that were extremely reliant on crude oil imports, to alternatives sources of energy and non-OPEC sources of oil. This was only reinforced 
by the major Companies, witnessing the irreversible loss of their prior positions, to look for newer, and often more expenses sources of supply - both in recovery costs (i.e. the extraction and production overhead) and in transportation costs. What followed then was a renewed global awareness of conservation and efficiency efforts, which first took hold in Japan, and spread to other advanced and developing economies. However, by far the most significant consequence was the gradual destruction of any cartel system that, in many ways, was the legacy of the Companies' control over the global oil industry. While OPEC inherited the mechanisms and framework that would allow it to theoretically become a cartel, its behavior, both as a single actor in the international economy and as composite Organization created the conditions market share disintegration, not accumulation. Indeed, the notion that OPEC was ever a cartel is fundamentally at odds with how it has behaved in the global economy. As Fadhil Chalabi has argued, in this period where the initial efforts of price defense evolved into an offensive goal of price maximization, any lasting hope for the Organization to keep the market share accumulation paradigm that the Companies built was lost - all for the short-term, tactical goal of revenue accumulation. ${ }^{266} \mathrm{Had}$ OPEC discouraged (or possessed the ability to discourage) the politicization of exports by its Arab faction in 1973-74 or even attempted to stabilize prices by increasing volume post-embargo to the point that would discourage consumers to look for alternatives and new supplies, its chance at a cartel would have been much higher. But considering that the nature of any cartel is to dominate market share, OPEC's hawkishness on price only encouraged consumers to look for alternatives and alter consumption patterns, thus undermining efforts at cartelization. OPEC's

\footnotetext{
${ }^{266}$ Chalabi, Oil Policies, Oil Myths: Analysis and Memoir of an Opec 'Insider', 172-75.
} 
offensive price maximization strategy, by default, eroded its potential at being a cartel. As Figure 3.4 shows, the dramatic decline of OPEC's market share is evident when comparing its 1973 figures (56\% of global crude production) to that of 1981 (40\% of global crude production). Therefore, while the Ascendancy era began with the Organization finding a dominant, arguably the dominant voice in the global oil industry thus ushering in a new, changed period for the global economy - the end of this era would also dramatically reshape the Organization's functionality and its impact on the global oil market. The decisions, Group consensus, and lack of consensus within the Organization, often times complicated by inter-member rivalries and renewed domestic crises in Member States, ultimately laid the ground work for the free-market based oil market that has been an often times, volatile fixture of the global economy since the beginning of the 1980s.

\section{Outside Forces}

\section{US evolution to active engagement}

Yet as the Ascendancy era of OPEC's institutional life began, the US and many of the home states of the major Companies, had by then begun to reach out to OPEC on its own terms, meaning bestowing official recognition to the Organization, and eventually going beyond that. While the intensification of the negotiations between the Companies and OPEC had much to do with this strategic shift, the preeminence of the Middle East region to US strategic thinking, due to the massive amount of hydrocarbon reserves in the region, its growing importance to the global oil supply, only to be exacerbated Cold War calculations vis-à-vis the USSR, played a crucial role in the US decision to actively 
engage OPEC as entity in and of itself - instead remaining in the position of background neutrality . As the core of OPEC producing power resided in the Middle East region, an active engagement policy with the Group became central to US grand strategy like never before.

\section{British Middle Eastern Withdrawal and US Twin Pillar Policy}

In February of 1967, the US National Intelligence Estimate (NIE), in highlighting the unique importance of the region to the global economy, advocated that the US "should for the foreseeable future, regard the Soviet presence and present Soviet policy in the Middle East as the primary threat to vital US interests". ${ }^{267}$ The NIE's pressing concern was a reaction to the coming perceived void that was to be left by the British withdrawal East of the Suez. ${ }^{268}$ Though London's decision was driven by a prolonged economic decline, coinciding with the gradual curtailing of its geopolitical power, ${ }^{269}$ its coming absence from the region - chiefly what that would project to the USSR and market worries regarding oil supply - became a significant source of concern for the US. ${ }^{270}$ The NIE summarized how the regional flux with the coming British departure would affect both US strategic concerns and the perceptions of Soviet decision makers:

\footnotetext{
${ }^{267}$ National Intelligence Estimate (NIE), “An Appraisal of U.S. Interests and Policies in the Middle East 1967-75,” 15 February, 1967 [Robert Anderson Papers, Box 147, Middle East 1967 (3)], 50.

268 J. Pickering, Britain's Withdrawal from East of Suez: The Politics of Retrenchment (Macmillan Press, 1998); S. Dockrill, Britain's Retreat from East of Suez: The Choice between Europe and the World? 19451968 (Palgrave Macmillan, 2002).

${ }^{269}$ William Wallace, "British Foreign Policy after the Cold War," International Affairs (Royal Institute of International Affairs 1944-) 68, no. 3 (1992): 423-42.

${ }^{270}$ J. C. Hurewitz, "The Persian Gulf: British Withdrawal and Western Security," Annals of the American Academy of Political and Social Science 401, no. ArticleType: research-article / Issue Title: America and the Middle East / Full publication date: May, 1972 / Copyright $\neg$ C 1972 American Academy of Political and Social Science (1972): 106-15.
} 
British withdrawal following World War II was followed by a decade in which new governments were taking their first steps, a combination of British and American aid and assistance linked with mutual security arrangements provided the essential support for early development and a degree of stability; the Soviets, concentrating in Europe on consolidating their position and at home on recovering from the war, did not pose an immediate threat to the area. In the 1958-67 decade, the Soviets, accepting for the present the status quo in Europe, have turned south to concentrate their major efforts outside of the Bloc in establishing the USSR as the dominant Great Power in the Middle East. In this decade" British power in the area has all but collapsed; the U.S." never militarily strong "East of Suez II, has moved into a period' of retrenchment and disengagement based partly on lack of agreement within the United States Government on the nature and seriousness of the threat to U.S. interests in the Middle East" partly on limited resources and partly on a conscious readjustment of policy toward a less militant resistance to the expansion of Soviet Influence into the area.... If within the Middle East Region, the military balance of power between the revolutionary and moderate forces can be established and the Soviets denied and extension of influence through Soviet "proxy military bases", the Soviet threat can be reduced to a tolerable level. Stated simply, most of the countries of the Middle East region are capable of withstanding the Soviet policy of "peaceful coexistence" as it is known in Western Europe; the Middle East cannot withstand the combined pressures of "peaceful coexistence" and Soviet support of "the liberation struggle" in the Middle East with massive Soviet arms aid.... The period 1967-75 will be decisive for the political forces contending for control, of the area between Asia and Western Europe. Geopolitically, on the availability of resources and vis-à-vis the apparent level of current commitment, the advantages rest with the Soviet Union. In the absence of any early basic decision by the United States, Western Europe and those free Asian countries with interests in the Middle East to meet the Soviet challenge there, it appears inevitable that the U.S. position as a Great Power in this region can be written off by the end of this period. ${ }^{271}$

The NIE's explicit reference to the changing regional environment in light of the British withdrawal rested on three realities. The first had to do with a lack of agreement on the extent of US physical involvement in the Middle East, meaning what kind of long-term

${ }^{271}$ NIE, “An Appraisal of U.S. Interests and Policies in the Middle East 1967-75,” 15 February, 1967, 4864. 
conventional military defense Washington would afford to the region writ large. The second was a diagnosis of the region when comparing US influential capability, which was undecided and possibly in relative retrenchment, as opposed to Soviet influential capability, which at a minimum was constant because of its proximity to the region. The American conclusion, as stated above, was that if trends continued, its position as a "Great Power" could inevitably be "written off". ${ }^{272}$ But finally, it was presumed that while the US could not massively build up conventional power in the region, there was a way to balance out Soviet influence by providing support to friendly governments.

It was under these circumstances that the rationale of the American Twin Pillar policy for the Middle East was developed. Accordingly, Washington would assist and oversee the strengthening of Iranian and Saudi military power in the Persian Gulf and the wider region. ${ }^{273}$ However, the US had to tread carefully. Though this policy was designed as a counterweight to the Soviet military threat and political influence in the region, the Twin Pillar policy, by extension, was also intended to balance against Sovietaligned regional states. The problem though was that some of those very Soviet-aligned states were fellow OPEC Members, chiefly Iraq, which by the beginning of the Ascendancy era was fully under Baathist control with Ahmed Hassan al-Bakr as President. Other states at the time, such as Libya and Algeria were wild cars, having become recently independent with severe economic challenges and/or political instability.

\footnotetext{
${ }^{272}$ Ibid.

${ }^{273}$ Shahram Chubin, "U.S. Security Interests in the Persian Gulf in the 1980s," Daedalus 109, no. 4 (1980): 31-65.
} 


\section{US pushed into role as de-facto intermediary in OPEC-Companies negotiations}

For most of the 1960s, the US was consciously ignoring OPEC, until in 1966 where both the US and UK decided to shift to open neutrality in the negotiations between OPEC and the Companies. ${ }^{274}$ The importance of the negotiations, the US fear of Soviet exploitation of OPEC Member State's discontent, and any instability resulting from tightening market conditions eventually moved the US away from its position of conscious indifference, to open neutrality, to a more active brokering role. From the late 1960 s to the early 1970 s, the US took on an open intermediary position concerning the negotiations between both sides, while also actively, albeit grudgingly, intervening in the dynamics of the oil industry. Washington was no longer just concerned about an abstract peaceful resolution to the OPEC-Companies dispute. The details of the negotiations, the ramifications of the outcome, and the particular dynamics within the global oil industry were now deeply affecting how the US approached the broader issue.

Washington's intervention took place on three, interrelated fronts: playing a broker role which often required nudging both sides in what turned out to be a tactical compromise; investigating, formulating, and ultimately prescribing its own policies that could potentially bring resolution to the broader OPEC-Companies conflict; and lastly, as a major energy consumer itself, altering its own domestic policy, via import control revisions, in order to increase the market share and revenue of some key OPEC states done to mollify their apprehensions about the negotiations. This pattern was first adopted

\footnotetext{
${ }^{274}$ See: Circular Airgram From the Department of State to the Embassy in Austria, 24 November 1965, Foreign Relations of the United States, 1964-1968, Volume XXXIV, Energy Diplomacy and Global Issues, Document 185; Airgram From the Embassy in Kuwait to the Department of State, 14 March 1966, Foreign Relations of the United States, 1964-1968, Volume XXXIV, Energy Diplomacy and Global Issues, Document 189.
} 
in relation to disputes with America's allies within OPEC and their respective concession holders. At the beginning of this Ascendancy period, it was the dispute between Iran and the Consortium that appeared to be the most worrisome for the US. In April of 1968, the Iranian government and the Consortium came to a temporary agreement to enhance the time needed to arrive at a more comprehensive resolution to Iran's request for additional control over price, volume, and, more importantly, production-sharing. ${ }^{275}$ Iran, as other OPEC Members, was counting on a certain level of rising revenue to match their previously described defense and development costs for the next few years. The US government, by that time deeply involved in the negotiations, sketched out what the Iranian strategy was vis-à-vis the Companies - of which was clearly a template that other producers were either watching or soon to be mimicking:

The Iranians would prefer, as the simplest solution (and the only one likely to succeed), that the members of the Consortium lift enough oil to provide, through the usual royalties and taxes, the desired level of governmental revenue.... If the Consortium is unable to do this, it must provide the National Iranian Oil Company (NIOC) with a sufficient quantity of oil from the Consortium area at a low enough price so that NIOC could make up the shortfall in revenue through its own sales or barter arrangements. The oil could be provided by modifying the terms of the Consortium's 1966 agreement to make barter oil available to NIOC, by turning over to NIOC an already producing field in the Consortium area, or by conferring upon the Iranian Government membership in the Consortium. The government has indicated that, in case of refusal, Iran might take unilateral measures to obtain the oil. ${ }^{276}$

Though the Consortium, under American insistence, considered as a possible solution additional output, which would increase taxes and royalties to the Iranians, the market

\footnotetext{
${ }^{275}$ United States Department of State: Office of the Historian, Foreign Relations of the United States, 19641968 , ed. Susan K. Holly and David S. Patterson, vol. Volume XXXIV, Energy Diplomacy and Global Issues (Washington: U.S. G.P.O., 1999), Document 223.

${ }^{276}$ Ibid.
} 
conditions in the late 1960s still had not tightened enough to justify such a move. However, Iran and other producers increasingly saw the insistence of production sharing if additional Companies output was not doable as the next best option - given the constraints of the concessionary holders and the market conditions.

Major producers had come to believe, that in light of the very modest gains regarding the prior fight over royalty payments with the concession holders, and considering that the posted price system was still intact (and under control of the Companies), that the logic of production-sharing was the most sensible path towards more revenue. Though this process was not a novel idea, it was under the OPEC umbrella where it gained traction. The simultaneous establishment of the National Oil Companies (NOCs) in producing states, some of which were older while others came about in the initial years after OPEC's formation, was the vehicle that host states intended to use to enhance revenue. ${ }^{277}$

Nevertheless, what production sharing essentially amounted to for the Companies was a de-facto, arbitrary reduction in the concession agreement within the host country, by the respective host government. In other words, it was seen as an indirect first step towards nationalization. In the past, Companies were only concerned about other firms; some fellow national firms while others foreign, competing for concessions. Though the threat of appropriation by varying host governments was a lingering concern, they never had to worry about an internal large competitor in the host country controlled by the host government, gradually splitting their concessions until nationalization was realized.

\footnotetext{
${ }^{277}$ Tordo, Tracy, and Arfaa, National Oil Companies and Value Creation, 15-21; D.G. Victor, D.R. Hults, and M.C. Thurber, Oil and Governance: State-Owned Enterprises and the World Energy Supply (Cambridge University Press, 2011).
} 
Moreover, for the Companies, acquiescing to the terms of the producing states, would not only lead to a market surplus, as NOCs would gradually saturate the market, but would irreversibly collapse the Companies ' market share.

Although each OPEC Member operated under different concessionary agreements, their collective experience in gaining only modest revenue increases with the royalty payments, and the many unresolved questions about new profit sharing arrangements, gradually created a consensus to production sharing. However, though Member States were beginning to coalesce around this new approach, it remained largely an aspiration, with the sole exception of Iran. It was here where the US government in 1969, noticed the beginning of this trend in Member States:

One of the latest of the numerous issues that have arisen between Middle Eastern governments and the holders of petroleum concessions in their territories concerns a demand by governments for participation in the exploitation of previously granted exclusive concessions... The principle that governments of oil-producing countries have a right to participate in the ownership of petroleum concessionaire Companies, even though the concession agreement makes no provision for such participation, has been publicly sponsored by OPEC.... Presumably, therefore, all the members of OPEC endorse this principle and could be expected at some time or other to present to the holders of exclusive petroleum concessions in their territories a demand for an equity share in the producing company. For various reasons, however, it is probable that the first and principal targets for that demand, when and if it is made, will be the "Big Four" concessionaire Companies-Aramco in Saudi Arabia, the Kuwait Oil Company in Kuwait, the Iraq Petroleum Company and its affiliates in Iraq, and the Consortium in Iran. So far, no specific demand has been made. Iran has threatened unilateral enforcement of participation but only if its revenue demands are not met by the Consortium. Public statements on participation have been made in some other OPEC countries, but only in Saudi Arabia has any government official had even an informal discussion with the concessionaire company on the subject. Nowhere have the manner, the timing, and the expected results of participation in existing exclusive concessions been set forth in more than the vaguest of terms. It would appear that none of the OPEC countries, except perhaps Iran, is prepared to make a real issue of participation in the near future-possibly 
not at all as long as governmental oil revenues continue to grow at somewhere near the rate governments expect. Iran's threat to spur the OPEC countries into concerted action to gain participation if Iranian revenue demands are not met cannot be taken seriously. For more than one reason, there is virtually no prospect of concerted action that would serve to bolster Iran's demands, primarily because those demands could be met only at the expense of other oil-producing countries. The probable results of the acquisition by governments of even a modest equity participation in such prolific concessions as those of the Big Four would be either (1) an increased per-barrel revenue for the government on oil exports, thus putting a further direct squeeze on oil-company profits, or (2) the provision to governments of sizable amounts of oil at production cost, the sale of which, probably at cut rates, would be likely not only to diminish the Companies' own sales but further erode the crude-oil price structure. Since crude oil prices are already gradually falling and measures now in force will insure to governments a rising proportion of oil export profits over the next five or six years even if no further steps in this direction are taken, the concessionaire Companies may be expected to dig in their heels on the participation issue. Governments would probably have to resort to extremely drastic measures in any attempt to force participation on their concessionaires-measures that would be likely to leave both sides worse off. We doubt that, with the possible exception of Iran, Middle Eastern governments are prepared or will be prepared in the next few years to take that risk, barring unforeseen developments that would seriously threaten the normal growth of their oil revenues. ${ }^{278}$

Though the US was dismissive of collective action, sparked by Iranian attempts to force production sharing on its concession holders, or even the Iranian ability to rally other Members, its concerns regarding Iran's own actions against the Consortium was quite apparent. And by this period, Iran, by far was the closest ally that Washington had in OPEC. The risks of instability that could be set off by Iran's decision towards forced production sharing on the Consortium, and the possibility of that becoming a template, regardless of the US dismissal of this prospect, spurned the US, under the Nixon

\footnotetext{
${ }^{278}$ United States Department of State: Office of the Historian, Foreign Relations of the United States, 19691976. , ed. Linda Qaimmaqami \& Edward C. Keefer, vol. Volume XXXVI, Energy Crisis (Washington: U.S. G.P.O., 2011), 8-9.
} 
administration, towards a different approach in order to address the revenue of concerns of producing states.

Due to Washington's fear and the purported unfeasibility of production sharing policies, the US, being the largest consumer of energy, decided to alter its domestic oil consumption matrix as to break the paradigm of the conflict between OPEC and the Companies. This was to be done by manipulating the American oil import quota system. Now the import quota system (i.e. the Mandatory Oil Import Quota Program) initially established in 1959 by the Eisenhower administration, ${ }^{279}$ was one of the key contributing factors in why the Bettencourt administration in Venezuela reached out to Middle East producers in the pre-OPEC days. ${ }^{280}$ As mentioned previously, this action, in restricting Venezuelan sales to the largest economy, only worsened its economic challenges at home, leading to collusion amongst the Member States. Amongst the main goals of the imposition of the oil import quota system by Washington was straightforward: to help buttress the eroding financial wellbeing of domestically based US oil firms that could not compete with the major Companies. ${ }^{281}$ President Eisenhower justified the system by saying that it was designed to "insure a stable, healthy [oil] industry in the United States capable of exploring for and developing new hemisphere reserves to replace those being depleted" and that its "basis...is the certified requirements of our national security which make it necessary that we preserve to the greatest extent possible a vigorous, healthy

\footnotetext{
${ }^{279}$ Walter J. Mead and Philip E. Sorensen, "A National Defense Petroleum Reserve Alternative to Oil Import Quotas," Land Economics 47, no. 3 (1971): 211-24.

${ }^{280}$ Memorandum of Conversation, February 20, 1963, between President Kennedy and President Betancourt and other U.S. and Venezuelan officials. Flight of capital from Venezuela. Confidential. 2 pp. Kennedy Library, National Security Files, Countries Series, Venezuela, March-May 1963.

${ }^{281}$ See: Y. Barzel and C.D. Hall, The Political Economy of the Oil Import Quota (Hoover Institution Press, Stanford University, 1977).
} 
petroleum industry in the United States." ${ }^{282}$ Moreover, on a security level, the system sought to lessen the threat of mass dependence of the US on foreign oil, thus "given restricted imports the domestic oil industry would thus be encouraged to locate and develop domestic supplies." 283

However, as the 1970s approached, the logic behind of this system no longer held up. The tightening market environment not only created the conditions where American based firms were no longer threatened by price erosion, but more importantly for the US, keeping this system intact was now leading to artificial inflated oil prices at home. As early as 1968, to deal with the problem between Iran the Consortium, Washington suggested lifting some import controls on Iranian crude. ${ }^{284}$ The added benefit would mean more crude oil imported from an allied nation, cheaper prices at home, and a lessening of the revenue concerns of Iran. Furthermore, this would also ameliorate some of the constraints that Iran's concession holders were placed under, primarily because of the market conditions and the OPEC-Companies negotiations.

This formula added to the serious debate that was already taking place in the US in terms of relaxing certain import quotas. ${ }^{285}$ As this debate broadened in the Nixon administration, the complications in the import quota system, the purported costs to American consumers, and pressure from major foreign-based Companies on the US

\footnotetext{
${ }^{282}$ D.D. Eisenhower et al., Public Papers of the Presidents of the United States, Dwight D. Eisenhower, 1959: Containing the Public Messages, Speeches, and Statements of the President, January 1 to December 31, 1959 (Office of the Federal Register, 1999).

${ }^{283}$ Charles J. Cicchetti and Willian J. Gillen, "The Mandatory Oil Import Quota Program: A Consideration of Economic Efficiency and Equity " Natural Resources Journal 13, no. 3 (July 1973): 402-03.

${ }^{284}$ Historian, Foreign Relations of the United States, 1964-1968, Document 223. 285 , Foreign Relations of the United States, 1969-1976. , 21-25.
} 
government pushed forward the possibility for instituting decontrol of oil imports. ${ }^{286}$ In August of 1969, the Central Intelligence Agency (CIA) released a study concerning the prospects of American access to global oil supplies for the next 15 years - in accordance with the internal debate and in possible anticipation of decontrol. The primary US concern was that if the walls were taken down, and the US market would become accessible to foreign oil similar to pre-1959, would the American economy become vulnerable to supply disruption - either intended or unintended? After surveying the global energy matrix by Companies, regions, and allies, the CIA, in its summary, was confident that it would be:

...highly unlikely that the US would encounter serious difficulties in obtaining its foreign oil requirements over the next 10 to 20 years, given the assumed termination of import restrictions. There are several major reasons for this judgment. Even 10 years from now, US import requirements would amount to only about 15 percent of the total amount of oil, which, it is estimated, would then be moving in world trade. Given the great and growing diversification of major sources of crude oil, supply is becoming increasingly invulnerable to disruption-voluntary or involuntary - by individual countries. Hence, although we would expect political upheavals to occur sporadically in various producing countries in the years to come, often with the chance of disrupting oil production for a time, such instances are unlikely seriously to curtail American access to world oil. Moreover, the oil producing states are heavily dependent on petroleum revenues. Even another Arab-Israeli war would probably not unite the Arab oil producers enough to let them long maintain an anti-US embargo. All things considered, the US, with the cooperation of US oil companies, would find it relatively easy to overcome the effects of any selective embargos that might occur from time to time. ${ }^{287}$

The CIA's assurances notwithstanding, they also factored in that the "most likely source of a serious disruption of world oil supplies" that could potentially "affect US access to

\footnotetext{
${ }^{286}$ R.H.K. Vietor, Energy Policy in America since 1945: A Study of Business-Government Relations (Cambridge University Press, 1987), 140-41.

${ }^{287}$ Historian, Foreign Relations of the United States, 1969-1976. , 34.
} 
oil is the Arab world." ${ }^{288}$ Though the market conditions were tightening, there was really no way of knowing what the global consumption patterns would become in the 1970s, or as will be discussed, how the Arab world's reaction to the Yom Kippur war of 1973, of which was severally discounted by the CIA, would ultimately be. Yet, with these calculations in mind, the US began the phased adjustment to its import quota system in the beginning of the 1970s. The alterations to the oil import quota greatly benefited Canada and Mexico, which had earlier enjoyed what was dubbed 'hemispheric preferences' but now extended to key OPEC Member Venezuela, which had been denied this hemispheric advantage for most of the quota years. ${ }^{289}$ Eventually the US would also include other its allies in OPEC by offering "special treatment", namely, Iran, Indonesia, and Saudi Arabia. ${ }^{290}$ And by 1973, after years of alterations to the import quotas that essentially rendered the program hollow, the Nixon administration formally put an end to the system.

\section{Interstate Dynamics}

\section{Instituting Nationalization}

At the same time that the US was adapting policies in reaction towards the OPECCompanies negotiations, significant changes were also underway within the internal structure of OPEC. Though by the beginning of the 1970s, the Organization's achievements in the negotiations were quite modest, they were enough to pique the interest of other minor producers that on their own felt quite vulnerable to their

\footnotetext{
${ }^{288}$ Ibid., 30.

${ }^{289}$ F. Tugwell, The Politics of Oil in Venezuela (Stanford University Press, 1975), 136-37.

${ }^{290}$ Historian, Foreign Relations of the United States, 1969-1976. , 89.
} 
concession holders. To these smaller players, the OPEC umbrella had much to offer. In this Ascendancy period, Algeria joined in 1969, Nigeria in 1972, Ecuador in 1973, and Gabon 1975. In virtually all of these second generational states that would join the Organization, the fundamental dilemma concerning host state's profit sharing and production sharing concerns (i.e. more revenue for the host government) vs. the concession holders' economic priorities (i.e. managing costs in a changing global oil industry) were essentially the same. Moreover, as newly independent states crossed the threshold from their initial, post-independence instability to finding government models with some governance capability, OPEC came to represent an institution battling the excesses of developed economies on behalf of the collective rights of the developing world. Indeed, it was this phenomenon that pushed the Organization to eventually become infused with the larger struggle of third world nations, particularly such institutions as the Non-Aligned movement. Thus, it was not only in these very modest producing states, as opposed to the major Member producers, that the stalemate in the OPEC-Companies negotiations finally broke. But more so, it was with the addition of these modest producing nations, particularly from the Arab world, that created the conditions for the politicization of the Group in the 1970s.

\section{The final phase of domino cascade}

\section{The implementation of Nationalization}

As 1970 approached, while the negotiations between OPEC's major producing countries - namely Iran, Saudi Arabia, and Venezuela - had somewhat temporarily been alleviated due to direct American involvement, the state of negotiations in other smaller producers had reached a stalemate. In Algeria, Iraq, and Libya the lack of progress was leading to 
radical action from each respective state. Algeria's entrance into the Organization in 1969, brought with it the legacy of French occupation of the country, compounded by the rising resentment from the Algerian government towards the concessions that French oil firms had in that country. ${ }^{291}$ In Iraq, the lack of mobility in Baghdad's negotiations with the Iraqi Petroleum Company (IPC) further emboldened the new Baathist elite that had secured power over the country. And in Libya, Muammar Ghaddafi's new Revolutionary system was now looking to the country's oil industry to pay for the post-revolutionary economic programs his regime was attempting to implement in that country.

OPEC's reaction, though accompanied by little capability to physically support its Member States, was nevertheless strong in their rhetorical defense, as exemplified in their June 1970 Resolutions XX.114 and XX.115, which supported Algeria and Iraq in the their negotiations with their respective concession holders. ${ }^{292}$ But as the impasse continued well into the summer of 1970, the governments of these modest producers of OPEC decided to take matters in their own hands. As Ian Skeet has noted, Algeria began the trend at unilateral concessional revisionism by retroactively announcing a new posted price, of which was almost 80 cents more per barrel than then current price. ${ }^{293}$ The Algerians did so by making the same arguments of other Members, that the price was artificially low and therefore needed a retroactive price adjustment. This time, however, they forced the issue on the concession holders. In Libya, since January of 1970, Qaddafi's revolutionary regime had been consistently applying pressure on the country's

\footnotetext{
${ }^{291}$ Ali Aïssaoui and Algeria: The Political Economy of Oil and Gas (Oxford University Press for the Oxford Institute for Energy Studies, 2001), 62-63.

292 OPEC, Opec Official Resolutions and Press Releases 1960-1990, 71-72.

${ }^{293}$ Skeet, Opec: Twenty-Fve Years of Prices and Politics, 59-61.
} 
concession holders for better profit sharing terms. As Daniel Yergin has chronicled, the greatest source of pressure was applied to the American independent firm, Occidental. ${ }^{294}$ So much so that as Libyan pressure forced Occidental to cut back production in Libya, by far their largest concession, fears of supply disruption forced the US government to intervene with other major Companies, advising them to make up the lost Occidental production via Iran. ${ }^{295}$ Though Libya's second tier status, both within OPEC and in the global industry, created a sense in Occidental that Libya's intransigence would soon subside, it was ultimately Qaddafi's threat of full nationalization that forced major concessions from Occidental. ${ }^{296}$ In the end, Occidental conceded a $20 \%$ increase in royalties and taxes to Tripoli, a 30-cent increase in the posted price, and more consequentially an increase of $5 \%$ of Libya's profit sharing. ${ }^{297}$ It was the latter, bringing Libya's profit sharing arrangement to $55 \%$ (with $45 \%$ for Occidental) that would erode, in rapid order, the remaining 50/50 profit sharing paradigm. Soon afterwards, all foreign firms in Libya reluctantly accepted this arrangement.

\section{Unity Achieved}

Events in Libya, and in other second generational countries of OPEC, created not only a new precedent that other larger producers had for years attempted to implement, but also a new unity of purpose within the wider Organization. The tacit acceptance of 'incrementalism' by the major producers Iran, Saudi Arabia, and Venezuela, brought

\footnotetext{
${ }^{294}$ Yergin, The Prize: The Epic Quest for Oil, Money, \& Power, 578-80.

${ }^{295}$ Historian, Foreign Relations of the United States, 1969-1976. , 122.

${ }^{296}$ Yergin, The Prize: The Epic Quest for Oil, Money, \& Power, 578-80.

${ }^{297}$ Ibid.
} 
about by measured US attempts at mediation, swiftly broke down. The Iranian government, the primary major Member that was once behind concessional revisionism, only to be pacified by the US temporarily, utilized the Libyan example for its advantage. The argument was quite simple; Tehran's claims was that if a problematic, revolutionary government in a modest producing country could secure better revenue sharing arrangements with its concession holders, there was no reason why major producers should be denied similar arrangements. Furthermore, the Shah's unwavering argument, both to the US government and the major Companies, was that Iran, being on the frontline against the Soviet threat in the Middle East, and being the main pillar of the Twin Pillar policy, needed to have special treatment vis-à-vis its oil revenue. Iran was just not another oil producer. As Iran was shifting towards radical concessional revisionism, Venezuela's parliament, only weeks before OPEC's $21^{\text {st }}$ Conference, which was scheduled to be in Caracas that year, raised the stakes with the Companies by instituting a $60 / 40$ profit sharing arrangement - up $8 \%$ from the prior 52/48 arrangement. 298

It was in the fall-winter of 1970-71 were events would come to a head. As OPEC celebrated its $10^{\text {th }}$ anniversary, the NOCs of the Member states had begun to prepare for what was becoming inevitable: major concessional revision towards full nationalization. With the December OPEC meeting approaching, Member States were no longer divided between those who were waiting for incremental steps towards revenue reforms vs. those who were considered radical. The Algerian and Libyan experiences galvanized the Group. In OPEC's momentous $21^{\text {st }}$ Conference in December of 1970 , for the first time, the

${ }^{298}$ Skeet, Opec: Twenty-Fve Years of Prices and Politics, 63. 
Organization, as a whole, inherited the position of the so-called radical factions. The Algerian and Libyan models were wholly adopted. In Resolution XXI.120, the Organization "resolved that all Member Countries adopt...to establish 55 percent as the minimum rate of taxation on the next income of the oil companies operating in the Member Countries." ${ }^{299}$ In other words, OPEC had collectively taken the initiative behind profit sharing. Moreover, the Organization implemented a blanket elimination to any existing disparities in the posted price (tax-reference price), with the caveat of consideration to any differences in "gravity and geographic location" of Member's specific crude quality. ${ }^{300}$ For years, these disparities allowed the Companies to divide and negotiate with the Members, usually with tacit cooperation from the US and UK, in order to diminish the possibility of mass collective action. Now that had been resolved, at least for the time being. OPEC had collectively instituted a direct committee to negotiate with the Companies on behalf of the Member states. And lastly, in its $21^{\text {st }}$ Conference, OPEC decided to eradicate the allowances that the Companies were given by the host states, effective January 1971.

After the Conference, the US understood that its efforts in bridging the gap between the Companies and OPEC, though successful at delaying, were now shattered. In a meeting between the Iranian government and US representatives on December 30, 1970 in Iran, US representatives were taken aback by the forcefulness of the Iranian government's attitude toward the inevitable price increase that was bound to happen in

\footnotetext{
${ }^{299}$ OPEC, Opec Official Resolutions and Press Releases 1960-1990, 76.

${ }^{300}$ Ibid.
} 
1971. ${ }^{301}$ Moreover, the US increasingly saw the actions of Iran and OPEC as mutually reinforcing, a marked change from the past where Iran counted on as holding OPEC to a gradualist, moderating position and an ally within the Organization. Simultaneously, other Members managed to put aside the particulars of their differences with one another, in order to exact whatever coming concessions they could obtain from the Companies.

The renewed negotiations were slated to begin in the early days of 1971. Iranian, Iraqi, and Saudi representatives headed OPEC's new unitary negotiating team, while Tehran was picked as the venue for what would become transformative negotiations for the history of the oil industry and for OPEC. ${ }^{302}$ The negotiations would last several weeks and would comprise four rounds. Fadhil Chalabi, OPEC's former General Secretary and a significant figure at the negotiations, stated that both sides remained very far apart from their positions, until in February of 1971, after the fourth and final round, OPEC offered "a final position that the Companies either "take it or leave it'." ${ }^{303}$ Behind the scenes, the US was still attempting to move the talks forward by playing the intermediary role. Yet the Companies displayed to US officials a deeply entrenched sense of mistrust towards the Shah and other Persian Gulf OPEC Members. They cited that no "assurance" from them would be "worth very much and that even if agreement reached on price, GOI (Government of Iran) will continue to put pressure on Consortium members for increased off-lift". ${ }^{304}$

\footnotetext{
${ }^{301}$ United States Department of State: Office of the Historian, Foreign Relations of the United States, 19691976 ed. Monica Belmonte and Edward C. Keefer, vol. Volume E-4, Documents on Iran and Iraq, 19691972 (Washington: U.S. G.P.O., 2006), Document 108.

302 OPEC, Opec Official Resolutions and Press Releases 1960-1990, 80.

${ }^{303}$ Chalabi, Oil Policies, Oil Myths: Analysis and Memoir of an Opec 'Insider', 59.

${ }^{304}$ Historian, Foreign Relations of the United States, 1969-1976 Document 113.
} 
Nevertheless, the sense of unity, determination, and persistence of OPEC Members - with the US, and to a lesser extent Western powers, now playing intermediaries - rendered the Companies unable to continue the status quo of domination of the oil industries in the host countries - whether of price, exploration, or volume. In a dispatch from the American embassy in Iran, after meeting with Companies representatives, the US assessment was that the "Companies had 'collapsed' and met virtually all OPEC demands." ${ }^{305}$ The Tehran Price Agreement was the minimum of the collective demands that OPEC Members had stipulated from the Companies. Becoming effective in mid-February of 1971, the agreement essentially concerned issues of retroactive financial adjustments for past revenues for Member States, an increase of Persian Gulf revenues in exchange for a pledge by those Members that they will not seek to increase prices for 5 years, a new agreed freight premium, and better terms for Libya (because of its proximity to Europe and high grade of crude quality). ${ }^{306}$ Yet, with the Tehran Price Agreement, a noticeable power shift had irreversibly gone to the producers.

The Agreement would become one of the most transformative events in the history of the oil industry because it marked the official end of the Companies unmatched domination of the industry. Though still having immense capital, political clout, and the most advanced exploration, production, and transportation technology, the Companies would never dominate in the way they had. Yet, though the Tehran Agreement began a process where both sides were to take a step-by-step approach towards an agreed resolution on price, and logically to be expanded out to a shared production agreement,

\footnotetext{
${ }^{305}$ Ibid., Document 114.

${ }^{306}$ OPEC, Opec Official Resolutions and Press Releases 1960-1990, 82-84.
} 
that destination was never reached. The official collective negotiations between the Group and the Companies became extremely problematic as individual negotiations between particular Member States and their concession holders broke down. In Iraq's case, the returning Baathist government, spearheaded by Vice President Saddam Hussein, was unable to cope with much of the delays and ultimately the irreconcilable price differences that Iraq in particular demanded of the Iraqi Petroleum Company (IPC), the main concession within the country. As a result, in 1972, Iraq simply nationalized the entire industry. ${ }^{307}$ In Iran, the Shah, though now clearly pushing for better conditions from the Companies and increased with agitation against them, still would not push towards full nationalization but adjusted his previous moderation stance within the Organization for this new era. ${ }^{308}$ Venezuela would successfully follow this piecemeal strategy, while Libya and Algeria would continue to agitate for special conditions because of their proximity to Europe.

Another complicating factor was the fallout from the collapse of Bretton Woods Agreement in August of 1971. As the US exit from the increasingly archaic post-WWII economic accords depreciated the dollar, Member States agreed among themselves that the initial terms set in the Tehran Agreement needed to be revised as it did not account for the major variations in dollar exchange rates. No one had anticipated that the US would allow the dollar to float. Getting the Companies to agree to revisions to the Tehran Agreement, while individual negotiations were happening, was extremely difficult for Member States. Fadhil Chalabi even goes as far as to say that the Companies used

\footnotetext{
${ }^{307}$ See: Ā. Husayn, Iraq: The Eternal Fire: 1972 Iraqi Oil Nationalization in Perspective (Third World Centre for Research and Publishing, 1981).

${ }^{308}$ Historian, Foreign Relations of the United States, 1969-1976 197;208.
} 
"delaying tactics, obfuscation with IMF data and general prevarication" to avoid such a revision - but ultimately relented to revisit the terms of the Tehran Agreement. ${ }^{309}$ However, this proved to be a futile effort. Though interim arrangements were made between both sides in the weeks and months after the collapse of Bretton Woods, by May of 1973, negotiations between both sides had broken down by reason of the irreconcilability of both sides' positions. It was ultimately this collapse of negotiations between the Companies and OPEC that would eventually become entangled into the penchant of certain Arab producers, many of them OPEC Members, to politicize oil exports.

\section{OPEC as a template for the Third World}

From this very long-sought but public battle, OPEC as an institution increasingly saw itself (and in some quarters became to be seen) as an important representative voice of many in the developing world. Up until that time, it was only the Non-Aligned Movement (NAM), created a year after OPEC's founding, that was the singular international organization specifically intended to protect the interests of developing countries. ${ }^{310}$ Member States and the Organization in general were seen solely through the parochial lens of the oil industry and specifically for the protection of their revenue intake. Nevertheless, the victory in the negotiations over the Companies, at least in the minds of many Member State governments - by virtue that it created a template for other raw

\footnotetext{
${ }^{309}$ Chalabi, Oil Policies, Oil Myths: Analysis and Memoir of an Opec 'Insider', 69.

${ }^{310}$ See: Alim Khan, The Nonaligned Movement: Achievements, Problems, Prospects (Novosti Press Agency Publishing House, 1985); M. Banerjee, The Nonaligned Movement (Firma KLM Private, 1982).
} 
material exporting countries - had the potential to enlarge the mandate of the Organization.

In theory, this dynamic was more under the surface. In subsequent conferences, resolutions, and press releases after from the OPEC's historic $21^{\text {st }}$ Conference and the Tehran Price Agreement, there was rarely any mention of any legitimate Third World issue. And this was at a time that many African countries (themselves raw material exporters), that had recently become independent of European domination, were still locked in struggles with their former colonial masters over the production and selling of their respective natural resources. To a far lesser extent, this same dynamic was also in play in Latin America. OPEC's succeeding efforts in the weeks and months after the Tehran Agreement were directed towards its own issues. These were mainly continued institutional development, procedural restructuring, implementing price reforms, expanding market research, organizational concerns about the loss of value in the US dollar, and monitoring the continued but ultimately futile negotiations with the Companies. $^{311}$

It was at the national, governmental level of certain Member States that issues outside of the export and selling of crude oil gradually seeped into OPEC's organizational behavior and made its way into the OPEC forum in general. This is not to say that there was an intentional effort by the Organization to politicize exports or manipulate prices. However, because for these States OPEC was their only basis of some modicum of independence and power within the international system, eventually many of their foreign policy priorities would gradually appear in the wider realm of oil production

311 OPEC, Opec Official Resolutions and Press Releases 1960-1990, 87-115. 
and exports. Moreover, for newly arrived Members, this institution had proven successful, at least according to their perception, in slowly rolling back the power and influence of the very same forces that had once dominated their economies. It was within this context that, underneath the procedural, public face of the Organization (i.e. in resolutions, official statements, and conferences), that certain Member States would utilize their export policies for non-economic, political reasons. And invariably, the OPEC brand, either directly or indirectly, would become attached to their decisions.

A forerunner of what was to come was seen in 1967, when the Arab Members of OPEC attempted to utilize boycott measures against those states that supported Israel during the 6-day War. ${ }^{312}$ But due to the market conditions of the 1960 s being too saturated, the embargo had little effect. More so, oil producers at the time were simply unable to muster independent leverage upon powerful consuming countries. The concession holders were much too dominant within host countries. The previously mentioned 1969 CIA assessment, though having sketched out the scenario of another episode of export politicization, were confident that "even another Arab-Israeli war would probably not unite the Arab oil producers enough to let them long maintain an anti-US embargo." ${ }^{313}$ Yet, by 1973, new market dynamics had dramatically changed the environment where that initial analysis was shaped. The 1969 CIA assessment, which was essentially the de-facto position of the West, did not take into consideration the abrupt end of Bretton Woods, the ramifications of a 'floating dollar', and the direction of the negotiations between OPEC and the Companies, which ultimately ended in collapse.

\footnotetext{
${ }^{312}$ See: M.B. Oren, Six Days of War: June 1967 and the Making of the Modern Middle East (RosettaBooks, 2004).

${ }^{313}$ Historian, Foreign Relations of the United States, 1969-1976. , 34.
} 
In May of 1973, OPEC, for the first time, officially declared that the talks with the Companies were at reaching at an impasse, since in their words, "the oil companies' representatives continue to adopt the same negative attitude vis-à-vis the main issue." 314 In other words, the fundamental lacuna concerning price and production was still unbridgeable, despite the many months that had transpired since the Tehran Agreement. However, in the summer of 1973, there seemed to be a tentative breakthrough. Both sides had hesitantly reached an understanding regarding further changes to the Tehran Agreement because of what OPEC had described as the "world currency turmoil". Previously, they had reached the same level of understanding the year prior, in two instances in Geneva. This was to be the final supplemental phase to that agreement which would theoretically address the Organization's concerns regarding the changing currency conditions as a result of the end of Bretton Woods, while keeping the Companies bottom from being significantly harmed. What it intended to do was amend the formula for posted prices; expand the group of currencies (from 9 to 11) that would make it more broadly representative of major currency movements against the US dollar; and introduce modifications towards price setting, such as recalibration of price formula by month as opposed to quarterly. ${ }^{315}$ But this arrangement needed to be settled on the new parameters of the Tehran Price Agreement, and specifically according to the new conditions on profit sharing. Yet, this did not take place, as the production costs to the producers did not keep up with the rising profits that the Companies were making on the market. Fadhil Chalabi, who has at the negotiations and having commissioned a study to investigate the matter on

\footnotetext{
314 OPEC, Opec Official Resolutions and Press Releases 1960-1990, 109.

${ }^{315}$ Ibid., 109-10.
} 
behalf of the Iraqi government, concurred that

by mid-1973 the prices of oil products in the main consuming centers were rising significantly. After netting back the crude oil price with costs for handling, refining and transportation, we reached a free-on-board (EO. B.) price in the Gulf that was well in excess of the official price of the $\$ 3$ per barrel stated in the Tehran Agreement of February 1971. This meant that the government's per-barrel share, according to that agreement, was equivalent to considerably less than two-thirds of the netback value of crude. In other words, the companies were reaping windfalls from the new prices of products without sharing them with the host governments. This fact signaled the need for the Tehran-agreed price to be increased at a commensurate rate so as to realign the profit-sharing basis, prior to any increase in the market price. ${ }^{316}$

While there was initially no consensus about once again revisiting the formula for the Tehran Price Agreement, as the Fall of 1973 came around, all Members, including still cautious Iran, was on board to challenge the Companies on this matter once again.

The Companies, however, refused to renegotiate a formula that they had previously assumed was resolved. In meetings from September of 1973, to mid-October, OPEC and the Companies attempted last minute attempts at resolving the issue. However, the gap proved much too large. As Member States were to resume discussions among themselves in Kuwait in early October of 1973, to discuss a response to the Companies, hostilities broke out between Israel and her Arab neighbors in the Yom Kippur War. Though the Arab Members of OPEC were still heavily involved in the negotiations with the Companies, under the OAPEC umbrella, which was foundationally set up as a politicized institution by Arab oil producing countries, some of these same OPEC Member States were planning a boycott against all the sources of support for Israel. Having the experience of the 6-day War of 1967 fresh in their minds, many in the West,

${ }^{316}$ Chalabi, Oil Policies, Oil Myths: Analysis and Memoir of an Opec 'Insider', 99. 
most importantly the US government, expected that the Arab states would at least attempt

to utilize the oil weapon. In a meeting on the Arab-Israeli crisis of 1973 in October 15,

1973, Secretary of State Henry Kissinger and his cabinet specifically went over the

possibility of this scenario coming to fruition:

Mr. DiBona: There are two possibilities. One, the Arabs cut off oil supplies from the Arab sources to the US alone. We could handle this, with some strain. Second, a total cut-off of Arab oil to all recipients. If we should try to equalize the burden, this would mean the US would be shipping oil out to Western Europe and Japan. This would require 5 or 6 million barrels per day from the US-one-third of the US consumption.

Mr. Rush: The economic impact in this country would be so striking that it couldn't be done.

Secretary Kissinger: What about the impact of a cut-off in Europe and Japan? They would go crazy.

Mr. DiBona: It would affect their attitude toward the war.

Secretary Kissinger: To say the least!

Adm. Moorer: They have already made their attitude clear. They expect the US to carry the entire burden.

Secretary Kissinger: And they have been ... unhelpful in the diplomacy.

Mr. Sisco: The pressures would increase from Europe, but they haven't lifted a finger to help us with the Arabs as it is. It cuts both ways.

Gov. Love: You would see an almost automatic flow of French and German technicians to the Arab countries if there were an oil cut-off. We would lose out in the area.

Mr. Rush: It's unrealistic to think they would be willing to suffer economically for us.

Secretary Kissinger: How can they avoid it?

Mr. Rush: By staying with the Arabs and keeping the oil flowing.

Secretary Kissinger: If they do this, they would be doing us a favor. What more could they do for the Arabs than they have already done? There is a limit beyond which they can't push us without losing their NATO relationship. There are two alternatives: (1) the Arabs may cut off oil to the US only; there would be some resolutions in the Security Council we would have to veto, but we wouldn't be that badly hurt; (2) the Arabs cut off oil to Europe. The Europeans would gain nothing, and they couldn't be doing anything worse to us than they are already doing. And if the Europeans try to do to us what we did to them at Suez, we could do more to them in retaliation. They can't afford to go into open opposition to us. Is that a fair statement?

All agreed.

Gov. Love: Any approach to rational thinking on the part of the Saudis 
will show them that a complete cut-off is not in their self-interest.

Secretary Kissinger: We have had no indication up to now that they intend a cut-off. They have been extremely circumspect. They have never threatened an oil cut-off in any official channel. Officially, they have taken exactly the opposite tack.

Mr. Colby: We have an indication that the Saudis are being very cautious about this oil country meeting tomorrow.

Secretary Kissinger: I sent them a letter yesterday telling them about our sending supplies to Israel. They replied that we should keep it in a low key and blame it on the Soviets.

Mr. Sisco: This was not from the King, but we think it is official.

Secretary Kissinger: I've been dealing with the oil guy. We have no indication that there will be a cut-off. But if there is, I think the President will go for the whole program, minus rationing. That would be the best way to bring maximum pressure on the Arabs.... ${ }^{317}$

Even with the scenarios that were studied, the US, at the eleventh hour, was confident that an oil embargo against them and the West was highly unlikely. Moreover, not only were they confident that the European reaction would keep the Arab producers from such an action, but in this particular conversation, US officials all but admitted that Arab producers were aware of US help to Israel in the war. In other words, one of the main reasons that the US, along with its partners, thought that they could handle the OAPEC embargo was because of its outreach to Saudi Arabia during the Arab-Israeli crisis of 1973.

What they did not expect was how the collapse of negotiations between OPEC and the Companies would amplify the planned OAPEC embargo against the high oil consuming free market economies and the rest of the world. ${ }^{318}$ And that is exactly what

\footnotetext{
${ }^{317}$ United States Department of State: Office of the Historian, Foreign Relations of the United States, 19691976. , ed. Nina Howland, Craig Daigle, and Edward C. Keefer, vol. Volume XXV, Arab-Israeli Crisis and War, 1973 (Washington: U.S. G.P.O., 2011), 529-30.

${ }^{318}$ H. Shaked and I. Rabinovich, The Middle East and the United States: Perceptions and Policies (Transaction Books, 1980), 242-44.
} 
happened. The negotiations that OPEC was having with the Companies' representatives in the fall of 1973 were mainly intended to adjust the profit sharing and production sharing provisions of the Tehran Agreement of 1971. From the standpoint of the Member States, they were never intended to radically alter the global oil industry, as the existence of the sheer existence of the Tehran Declaration was evidence enough that such an occurrence had already transpired. However, as talks reached an acrimonious impasse on October 8, 1973, Member States convened in both Vienna and Kuwait, ultimately deciding to take their demands into unchartered waters. A day after Kissinger's October $15^{\text {th }}$ cabinet meeting, OPEC decided to unilaterally impose adjustments to the Tehran Price Agreement by declaring sole proprietorship over the price of oil that their countries were exporting. ${ }^{319}$ For international cover, at least in the realms of international law, the Organization decided to frame this decision as being in line with Resolution 90 of June of 1968, which could broadly be interpreted that OPEC had jurisdiction of not just over production, but also over price. But in enacting this unilateral price measure, which would put Arabian Light crude to $\$ 3.65$ per barrel, raising total oil prices from $\$ 2.48$ to \$3.29 per barrel (in 1973 prices), OPEC would redefine the architecture of how oil prices would be set throughout the decade, only to change in the mid-1980s. In its press communiqué on October $16^{\text {th }}$ announcing the decision, the Organization affirmed that the $12^{\text {th }}$ of October was the last official day that the Companies were involved in price setting. Moreover, they stated that:

From this day on, actual market prices will determine the level of corresponding posted prices, keeping the same relationship between the two prices as existed in 1971 before the Tehran Agreement. The correction

${ }_{319}$ OPEC, Opec Official Resolutions and Press Releases 1960-1990, 115-16. 
for changing posted prices upwards or downwards will take place when the actual market prices of crude oil exceed or drop below the corresponding level of the new announced prices by one per cent.

What this ultimately amounted to was a whole scale revolution in the economics of the oil industry, as the Companies never thought that the Member States would so quickly abandon the established posted price system. From the companies' perspective, doing so would risk too much backlash against OPEC. However, the coming together of global demand, the shift of power to the producers (in that $54 \%$ of global oil output came from OPEC), the US and her allies official shift to neutrality, and the cohesion of OPEC created the conditions for the posted-price system to be abolished by Member States.

The OAPEC embargo against the supporters of Israel merely amplified a trend that had been coalescing for weeks. The convergence of these two distinct trends, of which OPEC Members' price disputes with the Companies was well into their third decade, both dramatically altered the economics of the oil industry. As Figure 3.1 shows, it increased the price of crude oil astronomically in 1974, with debilitating effects in North America, Europe, Japan, and even in some parts of the Third World. However, it firmly placed the domain of price control - for better or for worse - in the hands of oil producers for the next decade. The OAPEC embargo showcasing of the oil weapon had a profound effect on how oil producers, the most important institution being OPEC, were viewed by a host of global actors. The US gradually began to understand this fact. In the end of November of 1973, US Secretary of State Kissinger, in a meeting with President Richard Nixon highlighted this changing dynamic:

The Europeans and Japan have gone to the Arabs and said "What do you want us to do?" This is intolerable. If we give in to this: (1) It encourages 
the radical elements. (2) It gives an opportunity to the Europeans to escalate the proposal. (3) It gives an opportunity to the Soviet Union to escalate the proposal. For example, the Africans are now proposing to keep the embargo until the United States stops its racist policies. We could be faced by blackmail from all raw material producers. We will talk with the producers, but not under blackmail. There is some chance they will back off the embargo and give negotiations a chance. ${ }^{320}$

An emerging outcome from the oil shock of 1973-74 was that it was making oil producers, OPEC and OAPEC, in the eyes of the US as independent actors within geopolitics, and not just some arena of conflict with the USSR. In other words, the US was now seeing that decisions made in these relatively weaker oil exporting states was not necessarily compatible in the Cold War binaries of the day, but had a specific genesis internally. It was the fallout from the 1973 OAPEC embargo that fundamentally changed US strategy towards producers, not only abandoning its efforts of mediation between the Companies and OPEC, but more importantly, planning to counter the direct and indirect dependence of the advanced economies upon the Organization.

This price shock of 1973-1974 is what initiated a changing in relations between the US and oil producers, in that traditional alliances and enmities would dramatically shift. Initially, the US would hold Saudi Arabia, being the principal actor in OAPEC, responsible for the embargo. In a meeting with the US National Security Council (NSC), Secretary Kissinger was extremely worried about precedent, and specifically how if the US would give into OAPEC's demands, that a dangerous model would be created for others to threaten US national security via the embargo route.

We think if we yield to the embargo in the sense of bargaining with the Saudis on the specific terms for the conference, we will get ourselves on a

\footnotetext{
${ }^{320}$ Historian, Foreign Relations of the United States, 1969-1976. , 989.
} 
hopeless wicket. It would take too long. It would make the Saudis responsible for every point and their radicals would drive them. The British and French would be given an incentive to leapfrog. Every producing country would set up its own OPEC for the purpose of blackmailing us. Our position with the Saudis is that they have demonstrated their power. They have moved us off our position of letting things take their natural course. We have assumed a major responsibility for the negotiations, which they wanted. Now it is their turn to help. ${ }^{321}$

Already, the outlying Members of OPEC, namely Algeria and Libya, were now openly declaring how the use of the oil weapon against the US and the West was successful. In doing so, they would cite that the oil denial action was not just a response to the Yom Kippur War, but also colonial injustices that they had experienced that had emanated from the West. This was a tremendous turn of events for countries that only a few years ago had gained independence. In an interview in the midst of the embargo, Algeria's President Boumediene stated:

...that the Arabs have acted in a wise and positive manner, and have thus imposed their existence on those who have always thought little of it and have overlooked their interest in the Arab world. Those who overlook out interest have no right to ask us to safeguard their interests; nor do they have the right - when they are supporting the aggression we are subjected to - to ask special privileges from us. ${ }^{322}$

Moreover, Algeria, like other modest producers, was attempting to divide the positions of the US from some of the other advanced economies like Japan. ${ }^{323}$ With time, however, the US was able to reach an understanding with Saudi Arabia and with most of the OAPEC countries to end the embargo that was wreaking havoc on the advanced

\footnotetext{
${ }^{321}$ Ibid., 1006-07.

322 "Boumediene Discusses Foreign, Arab Affairs in Interview," Algiers Domestic Service 1974, T4-T5.

${ }^{323}$ Ibid.
} 
economies. Though some holdouts, such as Qaddafi's Libya or Baathist Syria, still stressed for the continuation of the embargo, their minority voices could not turn the tide of the shifting position of the end of the embargo's utility. ${ }^{324}$

However, ending the embargo, which again the US had expected to some degree, was not the same enterprise as reigning in price hawks. One of the major geopolitical 'side-effects' of the embargo, besides the panic and damage caused to advanced economies that supported Israel, was the creation of a constituency within oil producers price hawks - that now felt that the post-embargo prices was (and should be) the new normal in the international economy. In other words, from their perceptions, the years of disputes, setbacks, fallback positions, and forced compromises that they had accepted from the Companies and their home governments could now be 'corrected'. Though OPEC as an institution did not participate in the embargo, many producing countries within the Group obviously benefited from the elevated prices. Carrying over from its gradual changing perception towards the negotiations with the Companies, and the subsequent collapse of those talks, Iran quickly became known to be the leader of the price hawks. Indeed, this new dynamic halted the return to pre-embargo prices, regardless of the US understanding with Saudi Arabia. Well into the embargo, Iran's very influential Prime Minister, Amir Abbas Hoveyda, set out the parameters of their justification for higher prices:

Everyone complains because crude oil costs more, but no one has shed a tear over the fact that the price of grain has tripled and the prices of other products we have to import have risen at a dizzy rate. It is said that oil should not be trifled with because it is a basic product for guaranteeing

\footnotetext{
324 "Libya, Syria Will Not Comply," Tripoli Domestic Service FBIS-MEA-74-056, DAILY REPORT. MIDDLE EAST \&amp; AFRICA(1974).
} 
the development of production and wealth. But grain is still more important: It is the stomach's oil...the time has come to talk to each other frankly in the interests of clarifying relations between oil-producing and oil-consuming countries. Iran is not in favor of a reduction in the present price of crude oil. Saudi Arabia has displayed an initiative in this direction but the price has been fixed by OPEC, and there is no reason to change the decision. If anything, a new increase should be talked about. In the West, the cost of the manufactured products, synthetic fibers, and foodstuffs we import is continually rising, This year we will have an inflation of 8-10 percent, and it is largely a question of imported inflation. You say that your prices follow the laws of the market. Well then, why should the same rule not be valid for oil? Because it is supplied by underdeveloped countries perhaps? The two problems are interdependent. We have friendly relations with Europe, but it's now time to change the bases for international trade. ${ }^{325}$

Iran's reasoning eventually became the leitmotif that other producers would adhere to, both within the Organization and without. As Hoyveda explained, the rationale for increased prices was not just a Third-world backlash. It had functional purposes, two of which were the most important.

The first was the vast, albeit flawed belief of the day in the exhaustibility of global crude oil, which was the forerunner to the later peak oil theory (i.e. the world is running out of oil). In countless public interviews, the Shah of Iran would habitually cite this reason behind the support for higher oil prices from the producers' perspective. This belief eventually led Iranian decision makers, and their counterparts in other producing countries, to aspire to get the biggest 'bang out of their buck', primarily by tapering production in order to see prices rise. Though smaller producers, because of sheer market dynamics could not hope to influence global prices in that manner, larger producers such as Iran and likeminded counterparts (i.e. Venezuela, Saudi Arabia, etc.) could manipulate

\footnotetext{
325 "Premier Says Opec Front Will Not Be Broken," Milan CORRIERE DELLA SERA 1974.
} 
market dynamics effectively. Incidentally, Fadhil Chalabi, being present during the collapse of the OPEC-Companies negotiations, would specifically cite how Iranian technicians would report that Iran's 6 mbpd ${ }^{326}$ production was damaging the country's oil wells, and thus a moderate decrease to $4 \mathrm{mbpd}$ production would allow maintenance measures to preserve the oil fields. ${ }^{327}$

The second rationale of the price hawks had to do with how the increase of oil prices was the necessary adjustment to the collapse of Bretton Woods, the flotation of the dollar, and the subsequent rise of other global commodities because of inflation. Not only Iran, but also other governments such as Venezuela had long adopted such a belief. Because the OAPEC embargo and the abrupt OPEC price hike had put the governments of many Member States on the PR defensive, this line of argument became a constant fixture of how diverse governments would respond in public. Venezuela's Carlos Andres Perez made it a priority to point out that not only was the increase in prices a reaction to an increase in commodities from the advanced economies, but because of the heavy trade imbalance between developed and developing countries, that much of the money that the latter would get would return to the former. ${ }^{328}$ Even conservative Saudi Arabia, a skeptic of the price hawk strategy, would eventually concede the argument on the linkage between imported inflation into OPEC Members and the responsive price increase of crude. In a wide-ranging interview with Al-Anwar in Beirut before he was crowned King of Saudi Arabia, Fahd ibn Abd-al-Aziz directly tied inflation to purchasing power of

\footnotetext{
${ }^{326}$ Refers to million barrels per day

${ }^{327}$ Chalabi, Oil Policies, Oil Myths: Analysis and Memoir of an Opec 'Insider', 101.

328 "Pierre Salinger Interviews Perez on Energy Conference," Paris L'EXPRESS 1975.
} 
developing countries: "Inflation reduces the purchasing power of the exports of developing countries and is a means of swallowing up the revenues of developing countries" ${ }^{329}$ Thus, even after the embargo's end in the spring of 1974, the increase of oil prices was now gradually seen as justifiable by Member States, for both corrective purposes in relation to the past and for functional purposes for the present.

In the post-1973 environment, the Shah's urgency for higher oil prices, previously exhibited only to officials from the Companies and to the US, was now displayed openly, surprisingly often in the Western press. Following his Prime Minister's earlier stated rationale behind the prices, the Shah would consistently cite the new increase in prices as warranted because of his perception (which was shared by most producing countries) that crude oil, for the prior 20 years, had been sold at artificially low prices. This was one of the main driving factors as to why crude oil prices had not kept up with the rise of other commodities. Moreover, in an interview with the British Broadcasting Channel (BBC) in late 1974, the Shah emphatically affirmed this position: "We have been saying that you have been taking that wealth away from us, for a ridiculous price." ${ }^{330}$ In the interview, the Shah specifically compared the historical and rising costs of basic commodities most of which comes from the West or Western corporations - such as wheat, sugar, vegetable oil, and other commodities to the price of oil. He stated that Iran and other producers simply just "can't refuse to buy your goods" because of the necessity of those commodities. ${ }^{331}$ In the same manner, the Shah was telling the advanced economies to get

\footnotetext{
329 "Beirut Paper Interviews Prince Fahd," Riyadh Domestic Service 1975.

330 "Shah Discusses Oil-Price Issue in Bbc Interview," London Domestic Service 1974.

${ }^{331}$ Ibid.
} 
used to the price, just as developing countries adjust to price fluctuations of other commodities.

Other Member States also shared this sentiment. In an interview in early 1975 , Venezuelan President Carlos Andres Perez essentially repeated Iran's reasoning, but also carried the same logic over to manufactured items, of which the West still the epicenter of technology:

Our purpose is to make the great nations of the world understand that a global agreement must be reached by means of which the prices of our raw materials and our basic products will be in equilibrium with prices of the manufactured items we import. There must also be an equilibrium in the conditions under which we are given the technology we require for our development. In other words, Venezuela wants to use oil - which was the first basic product to become independent in the developing world - to achieve the independence of our raw materials, of our basic products, and thus the economic independence of Latin America.

Perez would further take this argument to what he advocated for, which was a "global arrangement" that would result in the "balance between the prices of oil, the other raw materials, basic foodstuffs, manufactured goods, capital and technology transfers". ${ }^{332}$ For Perez, like most of the Heads of States of OPEC, "the industrialized countries [had] imposed their conditions" for much too long, but now oil exports had become "a convincing instrument of negotiation". ${ }^{333}$ The fight had broadened out from mere profit sharing and production sharing to the larger question how the global economy had functioned. For Member States, the desire was clear; in Perez's words, "We want a dialogue leading to a new international economic order". ${ }^{334}$ And for the first time,

\footnotetext{
332 "Pierre Salinger Interviews Perez on Energy Conference," 78-80 LD.

${ }^{333}$ Ibid.

${ }^{334}$ Ibid.
} 
Member States economically acted on this desire for a changed, more equitable economic order. In March of 1975, at the Conference of Sovereign and Heads of State of OPEC Member Countries in Algiers, Algeria - by far the most important meeting that OPEC had since the Tehran Price Agreement - Members officially pledged financial and other types support for other, less developed nations. ${ }^{335}$ In doing so, they would end up creating the OPEC Fund for International Development, which would facilitate deliverance of aid, finance, and other means of support to the least developed countries. ${ }^{336}$ Not only was this possible by the steep rise of oil prices in the post 1973 era, but more importantly, OPEC had now set up to win the purported 'hearts and minds' of others in the developing world. ${ }^{337}$

\section{Outside Forces}

\section{Recognition of Vulnerability leads to Behavioral changes}

The inability of the governments of the advanced economies to prepare for such a new reality caused severe strains for them domestically. Virtually, all sectors of both advanced and non-oil exporting developing economies would feel the ramifications - from travel (both international and domestic), to manufacturing, to defense spending, with most of the burden coming hard down on the middle classes of these societies. And the economic, political, and psychological effects upon the advanced economies, and by extension, their

\footnotetext{
335 OPEC, Opec Official Resolutions and Press Releases 1960-1990, 130-35.

${ }^{336}$ I.F.I. Shihata, The Opec Fund for International Development: The Formative Years (Taylor \& Francis, 2010), 1-29.

${ }^{337}$ Mohammed Yeganeh, "Opec Special Fund: An Illustration of Solidarity with the Third World," OPEC Review 1, no. 4 (1977): 3-10.
} 
decision makers, reverberated throughout the 1970 s. ${ }^{338}$ The result was ultimately mass behavioral changes towards conservation, energy efficiency, alternatives, and diversity of crude supply - in both advanced and developing economies, chiefly those highly dependent upon crude oil imports. For the US, as early as only a few weeks after the end of the OAPEC oil embargo, major decisions were made to deal with America's energy vulnerability, of which the most significant was the creation of the EIA. ${ }^{339}$

However, singularly focused initiatives in disparate advanced economies were simply not enough. The dovetailing of OAPEC's embargo and OPEC's price hike, with the price hawks led by Iran solidly influencing the Organization's pricing policy, called for a more integrated macro strategy among the advanced economies. Though as 1975 rolled around, the governments of the advanced economies were still sketching out their own, individual responses to their particular energy vulnerabilities, with time, a collective approach started to take shape.

\section{The Advanced Economies React}

It was at the Economic Summit at Rambouillet, France in the fall of 1975, that advanced free market economies started to both collaborate with each other regarding the energy crisis, but also set forth concrete proposals that they had recently begun. In a highly significant meetings in mid-November of 1975 amongst the Heads of States of the US, UK, France, Japan, Italy, and Germany, the leaders of these free economies essentially decided to mainstream their collective policies to reduce the vulnerabilities of their

\footnotetext{
${ }^{338}$ F. Tugwell, The Energy Crisis and the American Political Economy: Politics and Markets in the Management of Natural Resources (Stanford University Press, 1988), 97-114.

${ }^{339}$ V. Stagliano, A Policy of Discontent: The Making of a National Energy Strategy (Pennwell Corporation, 2001), 15-30.
} 
economies to supply disruption. To do so, not only was conservation methods, new supplies via exploration, and alternative sources of energy discussed, but also more importantly, OPEC, for the first time, was now targeted by free economies. In an address to the group of leaders, US President Gerald Ford, after outlining the new American approach towards energy in general, introduced the specifics of what was the American initiative towards diversification of energy requirements under an integrated, cooperative approach of the free market economies:

In our opinion, the dialogue should be used primarily (1) to encourage the oil producers to develop greater awareness of their own stake in a growing and stable international economy, thereby reinforcing the moderate OPEC countries on pricing decision, and (2) to set in motion effective and cooperative programs by producers and the industrialized nations to ease the [lease developed countries'] LDC's economic and financial burdens caused by high oil prices. ... We do not think the dialogue will enable us to negotiate an agreement on oil prices at a cost we are willing to pay. The producers are not likely to cede their unilateral control over prices or to agree to reduce prices. The consuming nations would reap little or no advantage from indexation or any similar arrangement that would freeze prices at their current real level. This would legitimize current high prices, neutralize LDC and market pressures, ratify the gains of the cartel and make cartel management easier, and expose political leaders to the charge that they are conspiring with producers to drive prices up. Thus, we must continue to deal with high and uncertain oil prices with our own energy programs. High oil prices cannot be ignored; they have shaken our confidence, diminished our ability to deal with our problems, and compromised our economic development. There is no easy way to end our vulnerability and regain our freedom of action. We each must take the hard decisions necessary to implement and sustain strong and effective domestic energy programs, whose combined effect over time will be to shift the balance on the world oil market. To reinforce our individual efforts and to provide political impetus for greater future sacrifices, I hope that at the Summit we will pledge our nations to a maximum effort to reduce our dependency on OPEC oil imports in order to enhance our own economic well-being and to contribute to the long term energy needs of the world... Let me repeat what I said. In return for other countries participating in large new projects in the US which develop energy that would otherwise not have been produced, we will wherever feasible guarantee that a portion of the 
incremental energy production can be exported. Projects will be considered on their merits, in environmental, economic and regional contexts. ${ }^{340}$

Three new factors were now in play. The first was that the US had now officially, in the presence of its free market partners, given up as a mediator between OPEC and the Companies. Any hope of reverting back to the pre-1973 status quo in that the Companies and OPEC, albeit grudgingly, shared price control responsibilities, had now completely been abandoned. In admitting to their partners that the US no longer had the significant leverage over certain OPEC Member States that it once had, the American sponsored integration approach towards diversification became the de-facto policy. The second factor was the initiative itself. For the first time, the US would now integrate its domestic energy needs, at least in theory, with the domestic energy needs of its friends and allies. To do so, Washington was proposing importing foreign expertise in the US market and thus exporting that energy developed in the US back to other free market economies essentially, multinational technology transfer under America's watch. The third factor, in which would become more apparent in the years ahead, was a fundamental, and negative shift of the US towards the OPEC enterprise as a whole. In other words, US animosity towards OPEC is now clearly visible in full view.

At the same meeting, US Secretary of State, Henry Kissinger sketched out, for the first time that the weakening of OPEC had become the de facto position of the US government, although it was never officially articulated in public:

\footnotetext{
${ }^{340}$ United States Department of State: Office of the Historian, Foreign Relations of the United States, 19731976, ed. Kathleen B. Rasmussen and Edward C. Keefer, vol. Volume XXXI, Foreign Economic Policy (Washington: U.S. G.P.O., 2009), 124.
} 
Our goal is to reach a point where OPEC loses its unilateral power to control oil prices. This cannot occur before the 1980's, and in the next five years conditions mentioned by the leaders here will obtain. At the same time, we should not talk about OPEC as a monolith. OPEC sets prices because it has the power to control production. The multinational corporations, as was mentioned, do help it, because it is more difficult to get individual countries to cut prices if the multinational corporations, which are technically equipped and familiar with the market, manage exports for them. OPEC cuts production to achieve set prices. On the other hand, cuts in production are not uniform. This is an opportunity for us. If the West has the strength to absorb the financial surpluses of OPEC, they must export oil in order to import goods. Iran can no longer significantly cut production to sustain oil prices. Iran is tempted to increase oil to keep up exports. ${ }^{341}$

Kissinger's remarks were quite revealing because it exposed that the Companies had effectively relented to OPEC's control over prices. One of the main reasons for this dramatic turn by the Companies is that what they lost in operation control, they were gaining in tremendous windfall from the increase in prices - all the while OPEC was taking the collective blame for the exorbitant prices. The other Heads of State were in fact in full agreement with the diagnosis and the prescription, but had significant concerns on the for the short term. UK Prime Minister Harold Wilson brought to the table his country's overwhelming concern on not just oil supply access or price, but on the issue of precedent as it relates to other commodities. In his assessment, the Prime Minister stated that they was no use denying, from the perception of the advanced economies, the now inimical presence of OPEC:

... we have to face the fact that the OPEC syndrome is catching on. There are already phosphates-pecs, bauxite-pecs, banana-pecs and others. But we cannot rest on what we have achieved so far. The conditions of the developing countries have worsened while the expectations have increased. If any of us were importers of oil and other commodities, and faced

\footnotetext{
${ }^{341}$ Ibid.
} 
droughts and the need to import food at existing prices, we would also feel extremely bitter. Led by OPEC and other "pecs" they will be pressing...There is also a political alliance between the more militant oil producers and other developing countries... ${ }^{342}$

German Chancellor Helmut Schmidt carried this same logic to the possibility that OPEC would somehow create an alliance with other developing countries that would go beyond the commodities union precedent that Prime Minister Wilson feared. For Schmidt, the advanced economies would need to make the OPEC as an institution wholly responsible for the rise of oil prices, of which many of the developing world economies were suffering from as well, if not more than the advanced economies:

The developing countries have suffered worse than us. We have flexibility far greater than that of the LDC's. Many of them frequently have to depend on one single crop. We must find a way to break up the unholy alliance between the LDC's and OPEC. But we cannot say so in so many words. We should do this in the CIEC by discussing the balance of payments problems of the $L D C^{\prime}$ 's and showing how they are being damaged by this situation. We can make the point that the newly rich countries have to take part in new developmental aid in accordance with their new riches. We will also have to convince the LDC's of our genuine interest in their well-being, by helping them in the area of raw materials. We must find some way to make OPEC more responsible.

Both leaders were not speculating. Indeed, while prior to OPEC's unilateral price hike in 1973, solidarity with other raw material exporters were only alluded to, in the post-1973 era, OPEC as an institution really moved towards this direction. At OPEC's $47^{\text {th }}$ conference in Bali, Indonesia in 1976, Mohammad Sadli, OPEC's acting president for that year, laid out that the Organization was well on its way to find commonality with other raw material exporters:

\footnotetext{
${ }^{342}$ Ibid.
} 
One of our principal objectives must be in common with owners of natural resources and producers of raw materials in other developing countries to maintain the purchasing power of our export revenues. This should be regarded as a legitimate aim for developing countries, just as it is accepted that organized labor in the West is entitled to defend the purchasing power of wages. OPEC should be in the forefront of this struggle, but we should be judicious in determining at what level we should spring to the defense of our exports. We cannot simply ignore market forces and the threat of competition posed by alternative sources of energy. In exercising a policy of judicious appraisal, we are, at the same time, taking account of the interests of the non-oil-producing developing countries and of the rest of the world. The North-South dialogue will assume growing significance in the years ahead. The developing countries are increasing their efforts to bring about a new, more equitable and more progressive world economic order. OPEC must use its bargaining power vis-à-vis the industrialized countries to further the cause of the Group of 77 nations... ${ }^{343}$

Thus, from the European angle, the purported threat that was emanating from OPEC was no longer its role as a price maximizer and potential supply disrupter in the free flow of oil, but more so its potential to disrupt the traditional access that advanced economies had to other raw materials. Accordingly, all of the parties signed onto the US-led initiative of integrated diversification strategy to obviate any possibility of the recurrence of the 19731974 crisis. The British were the first to report that their North Sea exploration had begun to pay off with modest, yet promising amount of oil that had recently started to flow in their domestic energy basket. ${ }^{344}$ Moreover, the Japanese unveiled their specific shift to conversation, which would explode in not only new, efficient domestic infrastructure, but also in auto manufacturing that focused on less waste and more efficiency for the consumers of Japanese autos. As for the US, diverse initiatives such as a new energy bill, price decontrols, voluntary automobile fuel economy program (which ensured that

${ }^{343}$ H. E. Mohammad Sadli, "A Message from the President," OPEC Review 1, no. 1 (1976): 1-2.

${ }^{344}$ Historian, Foreign Relations of the United States, 1973-1976, Document 122. 
manufactures would increase efficiency by $40 \%$ ), new supplies (Alaska), and alternatives (nuclear) became the domestic to crisis. ${ }^{345}$

Yet once this decision was made by all parties to move forward with the integrated diversification strategy, not only was the US behavior towards OPEC bound to change, but more so, its traditional and long lasting relationship with certain OPEC Member States, namely Iran. In other words, the Shah's consistent push for high prices was bound to clash with what the free market advanced economies had agreed to in Rambouillet. For Secretary Kissinger, one of the lead architects of this new strategy, implementing it meant walking a very tight rope. To do so, what the US, through Kissinger's efforts, was directed towards was the soft disaggregation of OPEC essentially a neo-Eisenhower policy of reversing OPEC unity back to its semi-functional or even dysfunctional form. However, it could not be seen as a full forced assault on the Organization, because of the message that would portray to other raw material exporters. It could backfire and thus instigate for raw material exporting unions, as opposed to obviating them. What Kissinger suggested was breaking unity among OPEC Members through implied threats and but open inducements, and thus creating the conditions where the Organization would be separated from the least developed countries:

Iran provides the intellectual leadership, not the economic leadership. In addition, the countries sustaining oil prices are politically the most vulnerable; they cannot politically or psychologically sustain real confrontation with the West. We should not give them assurances by avoiding confrontation. The military threats from American officials several months ago resulted from lack of planning and some bureaucratic disputes. But after the initial outburst, and after all our friends had disassociated themselves from us, the oil producing countries came to us to ask what was needed to prevent this course of action from happening.

${ }^{345}$ Ibid., Document 124. 
We should attempt to convey the idea that Saudi Arabia cannot underwrite the oil price increases for free without paying an economic and political price. I am confident that if one country's attempt to exert pressure for lower prices is successful with a particular oil producing country, other consumers will jump in and take advantage. The oil prices are being maintained by moderate countries in OPEC-those who are most psychologically dependent on the US. We can do a lot if we are not immediately disassociated by our colleagues. We expect a cry of outrage from the producers. We can take that if we are not disavowed by our friends. We agree on the need for cooperation with producers. With cooperation we can separate the moderates from the radicals within $O P E C$, the LDC's from the OPEC countries, and prevent a lot of other "pecs." ... Our strategy is to link these energy discussions with commodities. We should try to break what the Chancellor correctly called the unholy alliance between the LDC's and OPEC. This can happen, and we can achieve our results, if they know that their disruptive actions could stop discussions on commodities or that they will pay a price in terms of cooperation, or military exports. In this way we can combat our dependence with a coherent strategy. ${ }^{346}$

Needless to say, in singling out Iran as providing the "intellectual leadership", the American task was now to roll back the desire of Iran and of other Member States on reliance on post-1973 price increase. Indeed, without addressing the Iran issue, the other elements to integrated diversification strategy would simply not work.

\section{OPEC Unity Challenged, first from within and then from without}

By the time of the Rambouillet Summit, Iranian influence within OPEC was by far the most dominant force in decision-making and the future direction of the Organization.

This was the result of primarily three factors that advantaged Iran more than any other Member State within the Organization. The first, which had been earlier alluded to, was Iran's preeminent position in American grand strategy against the containment of the

USSR. This single fact was what ultimately led to the years of economic and military aid

\footnotetext{
${ }^{346}$ Ibid.
} 
that the US gave to Iran in the 1960s and what would ultimately create the conditions for Nixon's Twin Pillar policy. As the US was winding down its wars in Indochina during the end of the Nixon administration and in the Ford administration, a war weary American public would not accept the US having any additional large, oversea contingencies. In the vital Middle East region, a strong pro-US regime in Iran capable of pushing back against Soviet infiltration of the region, and keeping the region stable from pro-Soviet proxies made sense to US decision makers. This was clearly exhibited during Iran's military intervention in Oman, where a communist insurgency, until being defeated, was threatening the rule of Sultan Qaboos. ${ }^{347}$

The second reason, which was a natural extension of the first, was that by the 1970s, Iran was by far the strongest conventional power in the region and in OPEC in general. While, as Kissinger had stated in Rambouillet, Iran's export capacity did not make it the economic leader, its place in the wider Soviet containment strategy of the free market economies and its conventional strength made it the intellectual leader. The third reason was simply what Iran had done for the Organization. While the creation of OPEC was essentially a Venezuelan initiative that was significantly helped by Saudi Arabia, it was Iran's signing onto a collective producers' movement that gave the Organization life and legitimacy in the eyes of the Companies and later the great powers. And it was Iran that had become the main proponent of higher prices, which was creating huge windfalls for other Member States. Iran's rationale on prices was convincing enough to be adopted by the majority of the Organization, and as explained by Venezuela's leadership, even

\footnotetext{
${ }^{347}$ Sepehr Zabih, "Iran's Policy toward the Persian Gulf," International Journal of Middle East Studies 7 , no. 3 (1976): 345-58.
} 
defended publicly in both international forums and with other foreign leaders. It was this dominance within OPEC decision-making that the US and the rest of the free market economies had to deal with when trying to weaken the Organization's collective resolve to continue on the price hikes that they were implementing in the 1970s.

However, the rise of Iranian clout within the Organization, the rise of Iranian power in the Middle East region, and Iranian influence in other aspects of international affairs caused suspicion in what had always been its principle future rival in the region: Saudi Arabia. In other words, the rise and substantial strengthening of Iran's strategic profile causing a classic security dilemma for the region, and with time, would bring in other regional actors over to the Saudi position. The Saudis understood that the continuance of the rise of crude oil prices was not only bad for OPEC's market share domination - regardless of the actual viability of the oil exhaustibility theory - it also was creating the conditions for the massive aggrandizement of Iranian power.

During this period of high oil prices, the Shah's government failed to judicially spend the country's oil windfall in a strategic manner, but would fritter exorbitant amounts on the latest military technologies, while engaging in ambitious urban renewal and modernization efforts of Iran's infrastructure. The problem, however, was that Iran's rate of spending continuously relied upon high prices, and in some instances continual increases in the price of oil. In other words, this was money that Iran did not have in its coffers yet, but as new monies came into Iran's Central Bank, old expenditures would clean out much of the reserves, at times resulting in budgetary deficits. In the post-1973 era, Iran, backed by Venezuela, Algeria, Libya, and at times Iraq, would continuously push for higher prices at each OPEC gathering. Conferences of OPEC would basically 
become export comparisons among Members and price adjustments, with the latter usually being an increase. The public rationale was always the same - the inflation argument, while privately the Shah's regime's ambition became an aggravating force in Iran's behavior within the Organization and towards other countries, particularly the US. In the mid-70s, the disagreements with the Saudis became so acrimonious that the Saudis, at one time, almost left the Organization because of price disputes with the other Members. ${ }^{348}$ And because the US needed his regime, fearing what may replace him, the Shah, by the mid-70s, had become virtually independent or resistant to US diplomatic pleas or pressure. But this newfound confidence was built upon a tenuous set of circumstances that was not sustainable. When those circumstances changed, the weakness of the Shah's enterprise became exposed.

These circumstances, the changing relationship between the US and Iran, Saudi fears of Iranian power, would eventually converge the interests of the US and Saudi Arabia together to reign in the Shah. Andrew Scott Cooper was the first scholar to find proof of linkage between the Saudi Royal family's fears of Iranian power with the desire of certain aspects of the US government to constrain the Iranian monarch's ability to increase prices. ${ }^{349}$ The US desire was very straightforward; lessen the price of oil, if so dramatically and neuter OPEC by creating disunity. But to do so would mean to actively weaken OPEC, which was now the US goal. Washington would have to fundamentally confront the driving force behind OPEC's unity and organizational decisions, namely Iran. The only method that the US could use was to enlist the help of another major

\footnotetext{
348 "Minister Says Saudi Arabia Almost Left Opec," Paris AFP 1975.

${ }^{349}$ A.S. Cooper, The Oil Kings: How the U.S., Iran, and Saudi Arabia Changed the Balance of Power in the Middle East (Simon \& Schuster, 2011).
} 
OPEC state that had the production capacity to drown out Iranian output; Saudi Arabia was the only country that had that ability.

Yet, the US goal was never to wage economic warfare on Iran or even threaten the Shah's hold on power. It is here where Cooper's research proves so consequential. Cooper found that as early as 1974, the year the OAPEC embargo ended, the Nixon administration had already sent out feelers to the Saudis for collaboration on oil prices. ${ }^{350}$ However, because of Iran's dominant position and its persuasive power with the other OPEC Members, any voice advocating anything else except for higher prices would simply be ignored. Moreover, there was an internal split within Washington, as Secretary of State Kissinger explicitly warned against such a move because of the unpredictability of what might occur and the Saudi resolve to actually go through with their part:

I doubt the Saudis would get out in front...I think they are trying to tell us - they said they would have an auction - it will never come off. They won't let us live with lower prices but they won't fight for them. The radicals would jump them on if they got in front. The Shah is a tough, mean guy. But he is our real friend. He is the only one who can stand up to the Soviet Union. We need him for the balance against India. We can't tackle him without breaking him. We can get to him by cutting military supplies, and the French would be delighted to replace them. ${ }^{351}$

However, though powerful, Kissinger would eventually lose the battle. The advocates of such a move in the Ford administration, most prominently Secretary of Defense Donald Rumsfeld and Treasury Secretary Bill Simon, would now begin collusion with the Saudis. The Saudis role was twofold: vocally protest, as best as possible, the increase of prices in organizational conferences and deliberations, all the while increasing production so

$350 \_$, "Showdown at Doha: The Secret Oil Deal That Helped Sink the Shah of Iran," Middle East Journal 62, no. 4 (Autumn 2008): 571.

${ }^{351}$ Ibid.: 574. 
supply dynamics would eventually decrease the price. From 1976 to the end of the decade, the Saudis openly advocated for a reduction in price. Being rebuffed by the collective will of most Member States, they decided to overproduce. From 1975 to 1978, Saudi Arabia went from producing just above $7 \mathrm{mbpd}$ to $8.3 \mathrm{mbpd}$. This was at the same time that other Members were either stagnating in their output, or even decreasing. Iran, during the same period, went from $5.9 \mathrm{mbpd}$ to $5.2 \mathrm{mbpd}$.

The US/Saudi desire for a sizeable drop in the price of oil did not materialize. However, the significant increases that Iran was expecting - in that their budget and future spending was tied to revenue that would never come in, proved have the most farreaching in its impact for Iran in the months ahead. The Saudi bucking of the OPEC trend essentially duplicated what the Shah had done for the US within OPEC deliberations a decade earlier. With time, as the Saudis, the Organization's largest exporter no longer was willing to go along with the collective will of Member States, OPEC's ambition of radically shifting the collective balance of power between the advanced economies to the raw material exporting states of the developing world - or at least creating an equilibrium - fell short by reason of the slow fraying of unity among Members.

\section{Intrastate Dynamics}

The Ascendancy phase began with the convergence of several macro elements in the global economy, only to be greatly accelerated by the erosion of any hope of consensus between the Companies and OPEC. Larger forces were at work within the global economy for years prior this era, of which the most consequential was the supply tightening due to soaring demand, the shift to OPEC oil dependence, the collapse of the 
posted price system, and the political empowerment of OPEC and some of its Member States within the international system. Yet, surprisingly, this important era within OPEC's institutional life and that of the global economy would end at the local level of intrastate dynamics. Naturally, every Member State experienced significant domestic political and economic changes that not only impacted the trajectory of each respective country, but also had important affects upon the Organization. Whether it was Qaddafi's consolidation of power within Libya throughout the 1970s (the creation of his oil-based welfare state), the consolidation of power in Algeria of its post-independence elite, Saudi royal transitions, or the first decade of independence for the UAE or Qatar, all were noteworthy.

Nevertheless it was the domestic political and economic level of Iran and Iraq that would prove to be the most consequential for both the future of these States, but also for the long-term trajectory of OPEC as viable and functional international organization. The collapse of the Shah's regime in 1979 and rise of Saddam Hussein in the late 1970s would be the most important and far-reaching intrastate event for OPEC during this period, and arguably throughout its history, of which the ramifications have reverberated well into the $21^{\text {st }}$ century.

\section{The collapse of the Pahlavi Monarchy in Iran}

As 1976 drew to a close, the oil income that the Shah had counted on from continual increases in prices simply never arrived. Revenue stagnated for the Shah, while mandatory and discretionary projects remained unfinished. With time, Iran's booming economy, always feared to be overheated, started to dramatically cool down. The Shah 
was well aware that dependence on oil was his Achilles heel. And there is some evidence that at least a sizeable portion of the oil profits were put back into the economy for diversification efforts, more education, expanded occupational therapy, and high-tech infrastructure. As Mohsen Milani has pointed out, oil revenues' contribution to gross domestic product (as percentage of GDP), though as high as 45\% in 1975-1976 was down to $31.8 \%$ in $1977-1978 .{ }^{352}$ Other sectors such as agriculture, industry/mining, and services were gradually, albeit painfully filling in the dominant position that oil had in the wider Iranian economy. In other words, the Shah's government was gaining ground on diversification of the economy, regardless of the fact that certain organs of his regime were corrupt. It was his spending habits with the oil money, and a dangerous reliance that on future revenue based upon unrealistic price hikes that created his budgetary deficit in the later 1970 s - all exacerbated by the dual US-Saudi oil initiative.

With the slowdown, the thousands of workers that poured into major Iranian cities from the countryside during the boom period gradually became either unemployed or underemployed. As Iran's economy went into crisis in 1977-1978, the contradictions to the very rule of the Pahlavi dynasty, which massive US financial, diplomatic, and military support was always aimed at masking, now started to unravel. This was a regime that regardless of its authoritarian tendencies, which certainly was the norm in the region and by many standards far from being the most onerous in terms of human rights and political liberties, had one fatal flaw that was never able to overcome. And that flaw was that it was re-installed by the US government in the aftermath of the coup against Iran's

\footnotetext{
${ }^{352}$ M.M. Milani, The Making of Iran's Islamic Revolution: From Monarchy to Islamic Republic (Westview Press, 1994), 60.
} 
democratically elected Prime Minister, Mohammad Mossadegh - a fact that most Iranians were well aware of and never forgot. The Shah never had any genuine legitimacy in the eyes of the overwhelming majority of Iranians, not because of his authoritarian tendencies, which preceding dynasties such as the Qajars were seldom shy about displaying, but because his rule was owed to outside powers.

The years of oil profits and the financial windfall that allowed the Pahlavi dynasty to buy support, pacify middle class anger at the lack of political freedoms, and build a major security and intelligence apparatus for the sake of protecting the regime was never able to build a qualitative sense of legitimacy for the Shah. And the Shah was never really able to combat this existential problem. By the time that Iran's economic woes became severe, another new aspect that the Shah's regime had to face was the newfound, and quite stern criticism of his human rights record from a newly elected, and idealistic Carter administration. ${ }^{353}$ The end of the Nixon-Ford era witnessed the political passing of all the Shah's supposed friends in the US government, chief of which was Secretary Henry Kissinger, who both admired the Shah as a political leader but also considered him a friend. Compounding the Shah's domestic problems with what was a bourgeoning opposition to his rule was a major miscalculation that his regime did in terms of targeting those they felt endangered the Shah's rule. The Pahlavi monarch and its security organs had always targeted the left, whether they were social democrats or even communists. The nationalist right was far too fragmented, and in some instances, wholly co-opted by the Shah's ideological affiliation for past Iranian dynasties. Yet, this made the religious right in Iran, a segment of the population usually thought to be poor and rural, as the

${ }^{353}$ C. Kurzman, The Unthinkable Revolution in Iran (Harvard University Press, 2004), 14-18. 
main source of opposition to the Shah. ${ }^{354}$ While the Shah had certainly understood that the religious right, most notably Ayatollah Ruhollah Khomeini, was becoming prominent in opposition towards his rule, his assessment was that the Ayatollah could never muster the support to challenge the Shah. Khomeini's exile to Iraq, and then later to France, was thought by the Shah as sufficient enough to get rid of what was thought of as a nuisance.

With confluence of the economic problems sparked by increased Saudi oil output, the pressure for enhanced human rights in Iran by the Carter administration, the coalescing of the religious right against the Shah (only to be expanded by the addition of other opposition elements), and finally major episodes of workers' strikes, the most important being oil workers in Southern Iran, the Shah's hold on power was became increasingly untenable. Indeed, it was the latter, as spelled out by Iran's Prime Minister Gholam Reza Azhari in one of the last interviews he gave before the government fell, that would present the Iran with unprecedented economic challenges, ultimately sending the economy in a downward spiral, in which the Shah's regime was not able to recover from. ${ }^{355}$ The final sign for the Shah was the unwillingness of his armed forces, of which he had dedicated so much time and economic support to building up, to support his regime during the protests. Indeed many of the higher brass of the Iranian military was either indifferent to the Shah's continual rule or some even openly sympathetic to Khomeini's call for revolution. This was clearly exhibited in a memo, months after the revolution, from the Office of the Secretary of Defense to Dr. Gary Sick from the National Security Council: "In the final analysis, the Shah did not command the loyalty of substantial

\footnotetext{
${ }^{354}$ Arjomand, The Turban for the Crown: The Islamic Revolution in Iran, 134-46.

355 "Text of 14 December Azhari Interview," Tehran Domestic Service 1978.
} 
numbers of the Iranian armed forces. The loyalties he did enjoy were confined largely to the most senior officers of the several services." ${ }^{356}$ Moreover, by this time, the Shah had terminally ill leukemia and thus was increasingly unable to lead in the way that he had before. In January of 1979, the Shah and his family finally left Iran for good, leaving a country in economic turmoil and political disarray.

\section{The Rise of Saddam Hussein in Iraq}

When the Baathist, after a series of political upheavals in Iraq, in 1968, returned to power, again via coup, this time under the leadership of Ahmed Hassan al-Bakr, their political fortunes were much better than their first attempt. Al-Bakr's tenure as President coincided, like his OPEC counterparts, with the shift of power to the producers, the rise of oil prices, and the massive increase of oil profits in Baghdad's coffers. By all accounts, under al-Bakr, though certainly not a democrat, the Iraqi state was able to govern under a technocratic, albeit one-party elite . Like Qaddafi in Libya, this meant that the development of an oil-funded welfare state. During this period, Iraq witnessed an increase in education to the population, expanded socialized healthcare, affordable housing, and major infrastructural development. One of al-Bakr deputies, a Baathist apparatchik that played a marginal role in the first Baathist government, was Saddam Hussein. ${ }^{357}$

With time, Hussein would become the Vice President under al-Bakr. And using this position, Hussein would surround himself with political actors and forces inside the

\footnotetext{
${ }^{356}$ United States National Security Archives: Library of Congress, Office of the Secretary of Defense, Washington, D.C., 25 September 1980, NLC-15-99-8-1-8.

${ }^{357}$ M. Farouk-Sluglett and P. Sluglett, Iraq since 1958: From Revolution to Dictatorship (I. B. Tauris, 2001), 134-37.
} 
country that throughout the 1970s would gradually render him the de facto ruler of Iraq. In doing so, as Sandra Mackey has stated, the Baath Party and the State of Iraq would become "virtually synonymous" under the al-Bakr-Hussein arrangement, as the Baathists subsumed all the organs of the State. ${ }^{358}$ Hussein's aggrandizement of power was also made possible, and largely facilitated by al-Bakr's failing health. Nevertheless, as al-Bakr stepped down, or as some have assumed, pushed aside, the Iraq that he left, now under formal domination of Hussein, was qualitatively stronger and richer than he had found it. With the exit of al-Bakr, and the formal beginning of Hussein's presidency in July of 1979, just a few months after the Iranian Revolution that toppled the Shah, the domestic undercurrents that had dramatically played out in both Iran and Iraq would soon clash, in violent ways, shaping both the future of those countries, and the direction of OPEC and its viability as an international organization for years to come.

\footnotetext{
${ }^{358}$ S. Mackey, The Reckoning: Iraq and the Legacy of Saddam Hussein (Norton, 2003), 232.
} 
CHAPTER IV • THE FRAGMENTATION PHASE: OPEC IN CIVIL WAR, 1980-1993

As OPEC entered the 1980 s, its confidence in its own strength and ability to set out an independent course of decision-making in the global political economy, and not just pertaining to the international oil market, was arguably at its height. In the prior decade, OPEC, as an institution, had managed to collectively defeat the once unmatched power of the Companies, nationalize (or proceed with the nationalization) of its Member States resources, wrest almost total control over pricing, attract many admirers in the developing world, and literally strike fear in the hearts of many governments of the advanced economies. However, beneath this confidence laid an extremely weak and tenuous foundation that in this new era, would precipitously and violently collapses. In the Fragmentation Phase of OPEC's institutional life, the majority of the gains that it acquired in the prior years would be lost, much of which never to return. The most consequential would be OPEC's institutional unity, freedom of action and independence from Outside Forces, and the ability to think strategically, as opposed to tactical moves intended for price defense.

In the realm of Market Forces, the 1980s began with what was supposed to be another boost to OPEC's influential power in the global political economy - rising prices. The fallout from the Iranian Revolution, particularly the crisis that engulfed Iran's oil exports as its oil workers went on strike (in order to remove the Shah), was initially a boon for all producers, not just OPEC (with the exception of Iran of course). But what would result from the second oil shock would not lead to any advantage for the 
Organization but would lead to a series of events that would dramatically weaken its power in the global economy, and subsequently in the international system. In the immediate aftermath of the second oil shock, the first fruits of the diversification and conservation strategies that the advanced economies had embarked on years prior would finally appear, minimizing the impact that the Organization would have on markets. Though the political instability from the Iranian Revolution and the Iran-Iraq War sent jitters through the markets, resulting in massively inflated prices, these concerns proved to be short-lived.

The advanced economies eventually would prove that because of their strategies in the immediate years after 1973, they, and thus large sectors of the global economy, were no longer dependent upon OPEC exports. The Organization made attempts to keep their market share, but internal disarray within OPEC and the evolution of the global economy to alternatives, conservation, and new production rendered those efforts fruitless.

The fallout from the Iranian Revolution not only would dramatically transform the intrastate dynamics of Iran for years to come, but would also reshape the domestic political, social, and even economic undercurrents of other Member States as well, specifically the Arab states of the Persian Gulf. Though the Arabs of the Persian Gulf, long distrustful and fearful of the Shah, initially were relieved by his regime's downfall, the rise of Political Islam in Iran would pose far more of a direct threat to their own political stability. Monarchial Iran was seen as a threat via conventional military dominance, but not to their respective regime's hold on power. The overthrow of a powerful, pro-Western monarchy, with one of the strongest militaries in the world, by a 
coalition of forces headed by religious figures, created a precedent which was easily replicable in the domestic contexts of many conservative Arab monarchies, specifically Saudi Arabia. Moreover, Iraq's majority Shia population was seen, whether accurately or inaccurately, as potentially vulnerable to influence because of Iran's Islamic Revolution, and how Iranian Shia clerical establishment lead the revolt that toppled the Shah.

This would have dramatic consequences in the interstate relations of OPEC Members. The fallout of the Iranian Revolution initially paralyzed any effective decisionmaking towards consensus in the Organization. As mutual recriminations escalated between Iran's new Islamic Republic and the newly empowered third Baathist state in Iraq (some spawned because of the Revolution while others were based on older territorial disputes), conflict became inevitable. Fear of revolutionary exportation would quickly lead the Persian Gulf Arabs to side with Saddam Hussein's Iraq. And as the tensions between Tehran and Baghdad led to open hostility in the September of 1980, OPEC as a unitary force irrevocably split, as two of its founding and influential Member States became engulfed in the bloodiest War of the $20^{\text {th }}$ century since WWII.

So consequential and transformative was the Iranian Revolution that the prevailing Cold War binaries of alliances and spheres of influences concerning key issues relating to oil production and the Middle East security architecture withered away as a result. The US, having faced international humiliation by reason of the storming of the American embassy in Tehran by revolutionary students, with the subsequent hostage taking of its personnel, was now fundamentally antithetical to the new Iranian government. And this antithesis was all encompassing in that the US would eventually use all the levers of its power against its former ally: economic Warfare, diplomatic 
isolation, intelligence sharing and later alliance building with Iran's enemies, culminating even in several instances of the use of force against the new Iranian government in latter stages of the Iran-Iraq War, albeit on a measured basis. Moreover, though in the immediate aftermath of the Revolution, many thought that the purported Western 'loss' of Iran would become a gain for the USSR, in time, the Soviets understood that the political transformation in Iran threatened their strategic profile as well - not just in the Middle East but also in other key theatres. Like the Persian Gulf Arabs and others in the region, the rise of Political Islam brought about untold threats to the Soviet Union, chiefly among the millions of Muslims in Central Asia that were always seen as fifth column to Soviet rule. Accordingly, the USSR also supported Iraq in its War with Iran.

However, what started from the Iranian Revolution did not culminate with the end of the Iran-Iraq War. The eight-year War which concluded in 1989 would not only consume any hopes of consensus for OPEC during this period, but would ultimately lead to the de facto disintegration of the Organization. And while the War ended in stalemate, its ramifications would yield more conflict.

Though the Persian Gulf Arab States supported Baathist Iraq with billions of loans, Hussein's regime was simply unable to pay back his debt to affluent Kuwait. Eventually, as a result, and only months after the end of the Iran-Iraq War, Iraq would embark on another costly military intervention against Kuwait - once again because of territorial disputes, specifically shared oil fields. This time however, the ramifications of such an action would be truly catastrophic for the future of Iraq as state, leading towards the near complete destruction of Iraq's military power, the eventual decimation of its civilian population via War and later sanctions, all the while causing ruin to its oil 
production capacity and export capacity. And as these events were paralleled by the continual increase of non-OPEC oil into the global economy enhanced by conservations methods and the use or alternative sources of energy, OPEC would reveal the extent of its dysfunction, causing many diverse speculations about its actual survivability in the international system in the years to come.

\section{Market Forces}

Throughout the 1970s, OPEC had used the inflation argument to justify higher prices. Yet, as mentioned previously, another potent argument, normatively accepted at the time, was the environmentally based belief of the exhaustibility of crude oil - essentially the forerunner to the peak oil argument popularized at the turn of the $20^{\text {th }}$ century. At the time, not only producers, but also environmental activists and even academics were constantly Warning about a coming depletion hydrocarbon resources. The fusion of these two intellectually separate premises - the inflation argument which called for retroactive corrective measures to balance out crude prices with the rate of manufactured goods and commodities with the second argument based on the non-renewable nature of crude oil - proved to be a powerful driving force in keeping prices inflated.

Yet, the unexpected impact of the political upheaval in Iran changed the ability for the Organization to implement measured increases or to keep prices elevated after an increase. In the aftermath of the Iranian Revolution, prices literally doubled, sending shock waves to both developed and developing economies. Iran's 1978 export figure of more than 5.2 mbpd $^{359}$ dramatically decreased to a little more than 1.5 mbpd in 1980

\footnotetext{
${ }^{359}$ Refers to million barrels per day
} 
(See Figure 4.1). This resulted in OPEC fundamentally losing control over prices. As panic and speculation led prices from their 1978 figure of $\$ 14.02$ per barrel $(\$ 48.37$ in 2011 figures) to $\$ 31.61$ per barrel (\$97.94 in 2011 figures) in 1979 (see Figure 4.3), OPEC was now losing control over the argument over prices.

This unprecedented rise in crude oil prices - now referred to as the second OPEC shock - for the first time, put the Organization on the defensive. ${ }^{360}$ However, though the price increase was a product of political upheaval in an important Member State, and certainly not because of any decision that OPEC had done collectively, the Group's decision makers felt a need to respond via public diplomacy. All throughout 1979-1980, OPEC as an institution, with its higher officials, and officials from its Member States gave unprecedented interviews and speeches on this very topic. The Organization felt that by explaining their perspective on the issue to diverse audiences, global public opinion would not hold them fully responsible for the price hike.

Moreover, the way in which OPEC responded to the dramatic rise in prices would unearth the deeply flawed premises that both the Organization and its officials had about the global economy and the oil industry in the 1980s. It was these series of miscalculations that would lead to OPEC's dramatic weakening over the oil industry, as it relates to prices, its export policy, and most importantly, control of market share.

\footnotetext{
${ }^{360}$ M.S. LeClair, International Commodity Markets and the Role of Cartels (M.E. Sharpe, 2000), 230-80.
} 
Figure 4.1: OPEC Crude Oil Production by country, as Member States joined the Organization, 1978-1993 (1000 b/d) Source: OPEC Statistical Data. http://www.opec.org/opec_web/en/data_graphs/330.htm

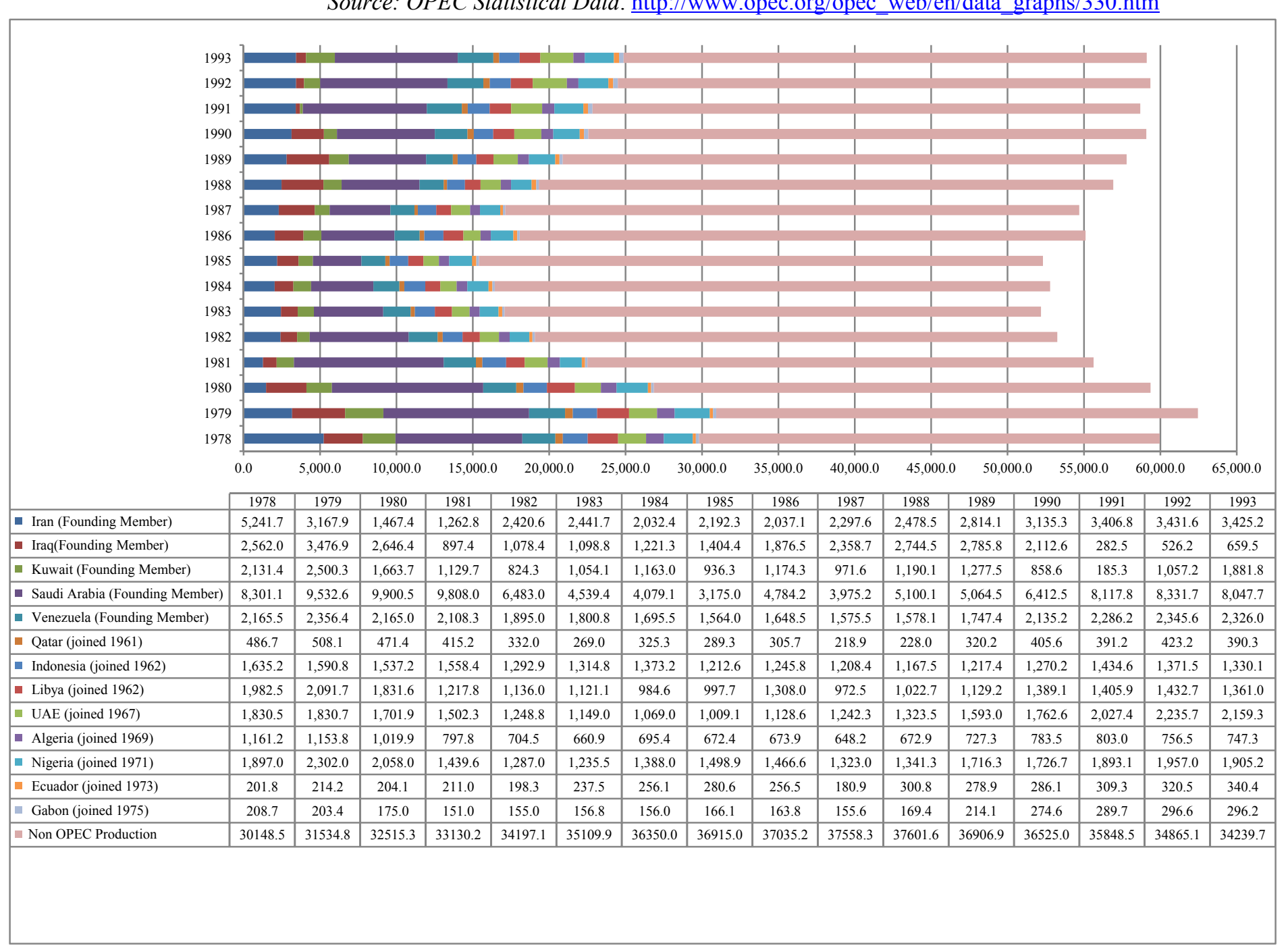


Figure 4.2: Global Oil Consumption by Regions: 1965-1993 (Thousand barrels daily) Source: BP Statistical Review of World Energy June 2013

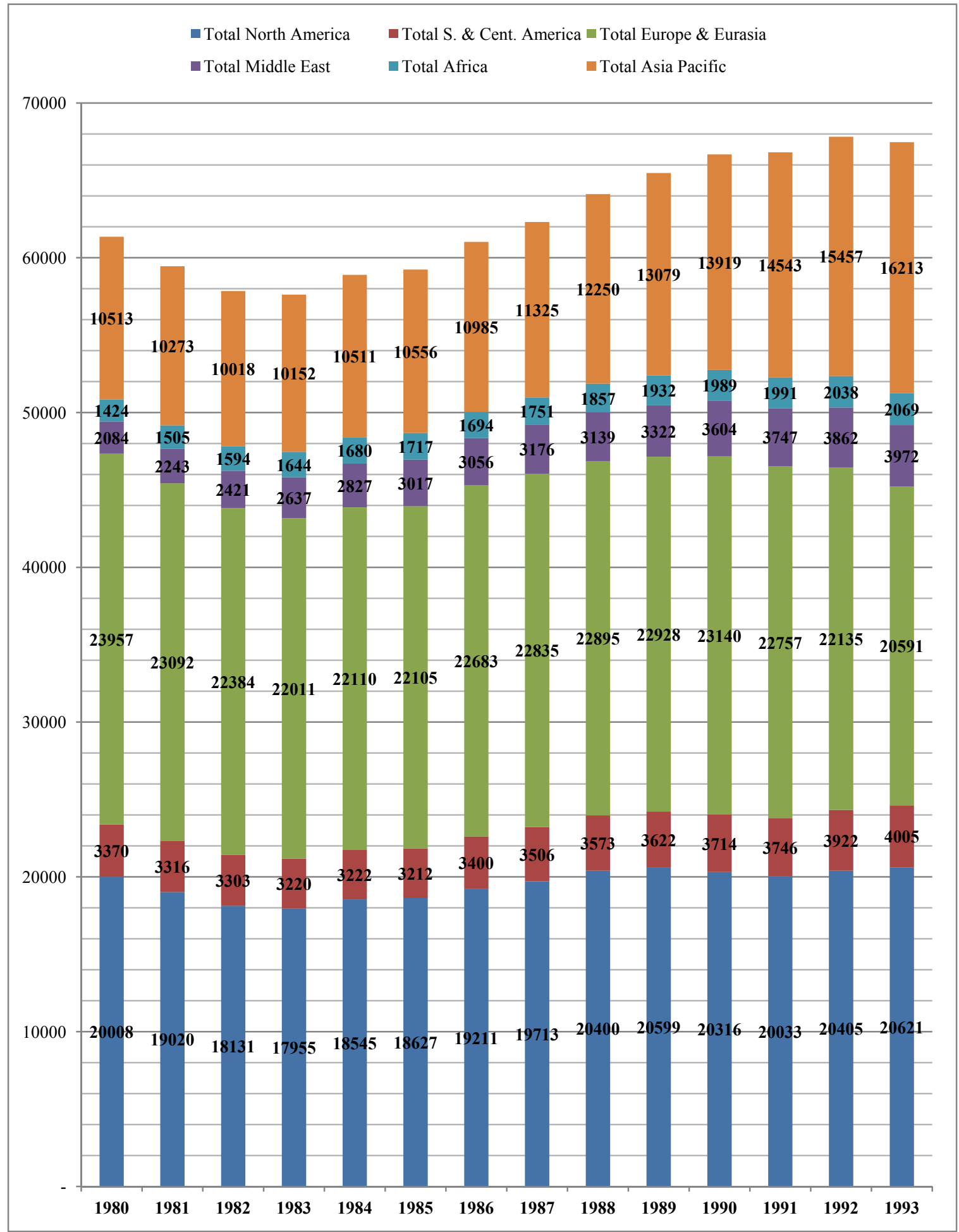


Figure 4.3: Crude Oil Prices: 1978-1993 (US dollars per barrel) Source: BP Statistical Review

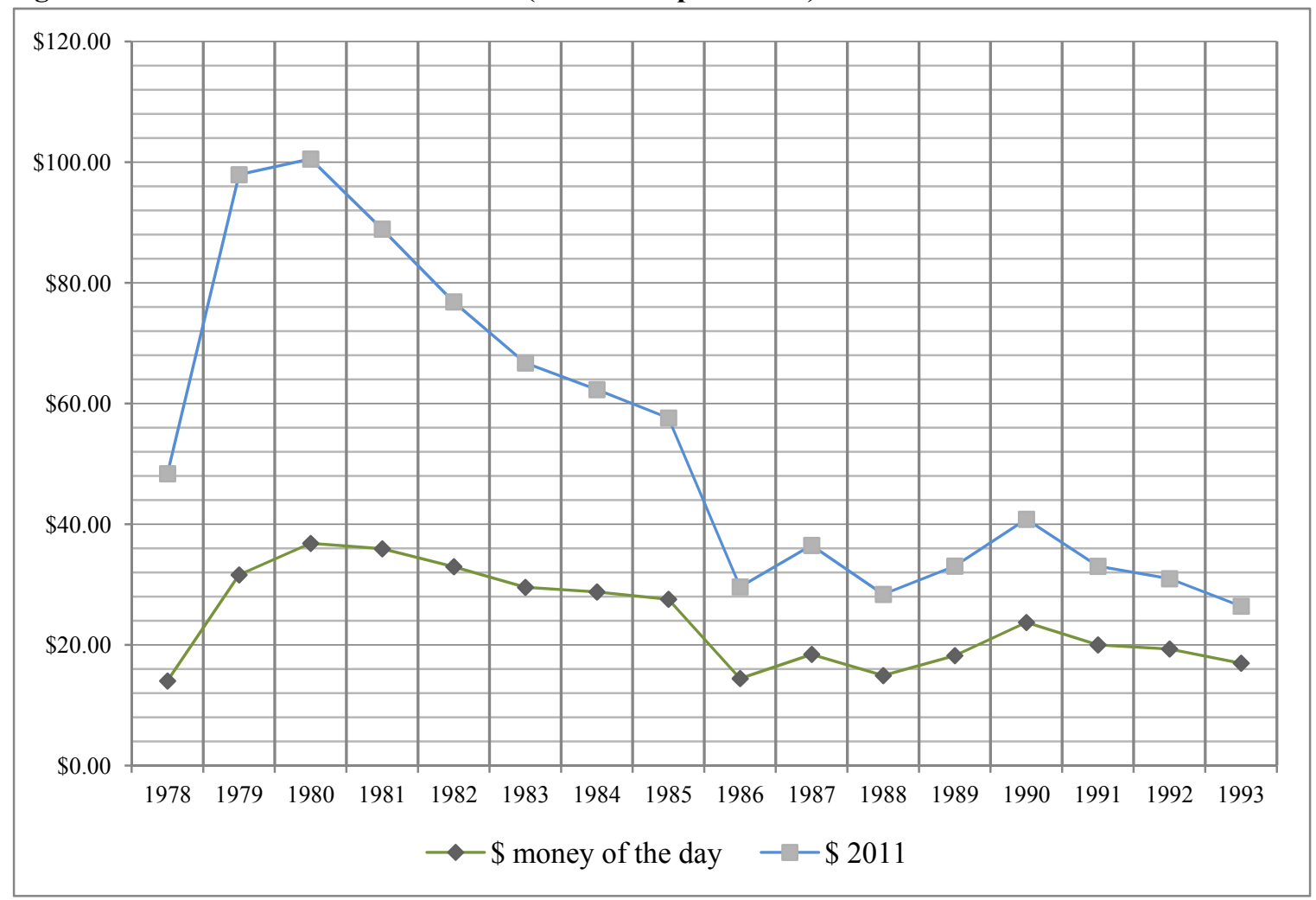

In a series of speeches made to not only justify the high prices of crude, but also to explain the fallout from the loss of Iranian exports, and on the future of production, OPEC's Ecuadorian Secretary General Rene G. Ortiz would continuously highlight the binary inflation/depletion argument. In an address to the First Arab Energy Conference in Abu Dhabi in early March of 1979, Secretary General Ortiz laid out the thinking of OPEC's production position concerning the next few years:

The fact that the primary fossil fuels available, and their ultimate recoverable reserves, are finite and of a non-renewable nature, points to the alarming situation that these exhaustible resources can only be secured over a limited time period and hence attention is dramatically drawn to the future availability and supply of energy required for the anticipated economic development. This fact is particularly acute in the case of hydrocarbons where at the 'present rate of exploitation the hydrocarbon era is rather short and could, in fact, be measured in decades. This situation, serious enough in itself, is aggravated by the slow pace of development of alternative sources of energy and the low prospect 
of a real breakthrough in making these sources available at a reasonable cost, and in the bulk required, to ensure a smooth transition from the oil era to one hopefully based on renewable resources.... This prominent position of oil in the total energy demand was due mainly to the versatility of its use on the one hand and the fact that crude oil prices were artificially maintained at an unjustifiably low level on the other....Hence, crude oil, which for some Member Countries is the only source of revenue, was, for a considerable number of years, undervalued and over-consumed as if its supply was unlimited. As a consequence, since the mid-Seventies, an important structural change has occurred in the oil industry whereby oil production and oil prices began to be administered by Governments to whom revenue, compatible with their needs, economic development and aspirations, made the production and export of crude a permanent national objective to be handled through governmental policy. It is worth mentioning here that an artificially low price for petroleum in the past prompted over exploitation of this limited depletable resource and the continuation of such policy would have proved to be disastrous from the point of view of the world economy. Fortunately, OPEC Countries' actions, particularly those of the 70s, came just in time, serving as a preventative signal before having to face any major crises. Actually, as far as OPEC Member Countries are concerned, the policy goes a step further, since it covers a dual objective; firstly, that of obtaining an equitable value for their resources and secondly, the inducement of the development of alternative sources of energy, together with encouraging real conservation measures and the prevention of wasteful utilization of oil. Additionally, the Organization, while recognizing the vital role of oil and gas supply to the world economy, and at the same time committing itself so that the essential requirements of the consuming countries are met, believes that conservation and the rational use of hydrocarbon resources is a fundamental requirement for the well-being of, and national asset to, future generations...the issue of the availability of supply of OPEC hydrocarbons should account for all the economic, social and other constraints compatible with Member Countries' needs and development. Thus, these countries should not be expected to produce beyond what is economically justifiable. ${ }^{361}$

Ortiz's remarks are very revealing because he openly states that OPEC's objectives, at least at that time, was ultimately to transition to a less oil dependent world. Coming from the perspective of the exhaustibility theory, this reasoning, in fact, does make logical

\footnotetext{
${ }^{361}$ R.G. Ortiz and Organization of Petroleum Exporting Countries, Viewpoint: Selection of Speeches (OPEC, 1981), 1-2.
} 
sense - even for an institution that depends so heavily on the revenue from its oil exports. The Organization had figured that this resource would largely be done away with in a few decades, so its finite nature justifies a higher price while the world economy adjusts to other sources of energy, and with more conservation methods.

But because of the uncertainty surrounding Iranian exports, OPEC's claim to market stabilization was also coming under severe criticism. With the defeat of the Companies and the wresting of control over prices, OPEC's primary argument was that if producers actually had a say (or control) over prices, there would be a better stabilizing influence in the market, in the event of supply disruption. This argument largely went unchallenged throughout the 1970s. However, when supply disruption actually came about, this time quite a severe disruption, OPEC's ability to act for the 'global good' was found wanting. Fadhil Chalabi, OPEC's future Secretary General after Ortiz, understood this dilemma for the Organization:

The real significance of the Iranian oil crisis is that it has suddenly - and dramatically changed - previous conclusions on OPEC oil and its role as a stabilizing factor in world energy markets. In doing so, however, the crisis has merely brought to the surface certain undercurrents which were undoubtedly in movement before the crisis, and which, if no appropriate measures had been taken, would nevertheless have confronted the world with the same issues, if perhaps at a later date. Only six months ago, people in the oil industry were still talking about the possibility of a sustained OPEC excess capacity in production, excess that would continue for years to come. The instability presently characterizing the world oil markets would, however, indicate that such conclusions were erroneous. It is now obvious that the disappearance of Iranian oil exports has not been completely made up by the increase in production from those excess capacities. What has happened, in fact, is that most OPEC Countries are currently producing at near their full capacity; and those that have increased production in order partially to make up for the loss of Iranian production cannot continue doing so without jeopardizing their production policies. This does not imply that the possibilities of expanding capacities in many OPEC Countries do not exist. But the dilemma in 
which such countries now find themselves is clear: is there sufficient incentive being offered to motivate them to undertake the large-scale and capital-intensive investments necessary to cope with the increasing demand, given the fact that the income derived from the depletion of their existing resources is now more than ever needed to meet the pressing

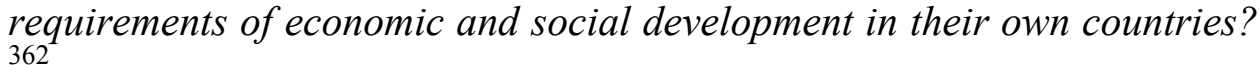

Chalabi's admission laid bare the major contradictions with OPEC's policy of uncontrolled elevated prices in the 1970 s, which was dramatically worsened by the politicization of the exports from OPEC's Arab Member States. In focusing on the "dilemma" of OPEC Members - namely the producers' predicament of either investing in excess capacity with additional windfall or saving those monies for the "pressing requirements of economic and social" needs at home - Chalabi's statement showed the fundamental inability of OPEC to think in strategic terms vis-à-vis their consumers. More importantly, it showed that OPEC's thinking was based upon a reliance of the continual increase in demand - of which its inaccuracy would only aggravate by the exhaustibility theory. In addressing its possible concerns about Iran's future production and market share, Iran's new Oil Minister in the provisional government, Ali Akbar Mo'infar, exemplified this reasoning, which had been adopted by most of OPEC:

We are not at all worried about the sale or our oil. Even if this quantity of oil were to remain under Iran's soil, its price would increase day by day and would become more expensive and we would not have been worried. Therefore, we shall export the amount which we require in order to obtain foreign currency. This is our goal, and at the moment our program is to keep the present level of production and to sell the same amount as before. We have a sufficient number of customers for what we wish to sell. ${ }^{363}$

\footnotetext{
${ }^{362}$ Fadhil Al-Chalabi, "What Lessons from the Iranian Oil Crisis?," OPEC Review 3, no. 1 (1979): i-ii.

363 "Oil Minister Interview," Tehran Domestic Service, November 14 1979, R6-R12.
} 
Furthermore, this reasoning was not just adhered to by the Organization or other producers. Many in the advanced economies also believed that the second oil shock was proof of the continual and even rise of the power of OPEC in the decade. ${ }^{364}$ It was clear, that based upon Ortiz, Chalabi, and other OPEC and Member State officials, that the no one really imagined the actual fruition of conservation methods and alternative sources of energy. If they were viable, it was thought that they would be years away, for clearly OPEC's production, pricing, and planning policies made little room for them in their strategic analysis on the dynamics of global supply and demand.

As a result, the Organization entered the 1980s with a major sense of confidence, accomplishment, and determination. Only literally days before the start of the Iran-Iraq War, which would fundamentally end OPEC unity and functionality for years, OPEC's September 1980 press release would celebrate its $20^{\text {th }}$ anniversary by proclaiming that:

The controlling power in the hydrocarbons industry of the OPEC Member Countries is now firmly in the hands of the rightful owners, namely the oil producing nations. Their governments are now guardians of a substantial proportion of the earth's last reserves of a precious commodity and are attempting to administer this responsibility with wisdom and moderation, taking due account of the national interests of their own countries. Production and prices are being governed by consideration of the depletability of the oil reserves: in the interests of both producers and consumers OPEC is vigorously advocating measures aimed at enabling a smooth transition from the oil era to that of alternative forms of energy. Conservation, increased investment in existing and new fields, measures requiring further exploration and/or enhanced recovery; and the development of both conventional and non-conventional alternatives - all these needs are constantly being placed in the foreground of discussions by this Organization. There are signs that OPEC's policies are coming to be recognized for what they are, namely, genuine pointers to the realities and the challenge of the energy and economic development of the world. Never before has there been such energy-consciousness as there is today. And it cannot be denied that OPEC has been the prime mover behind this

${ }^{364}$ Walter J. Levy, "Oil and the Decline of the West," Foreign Affairs 58, no. 5 (1980): 999-1015. 
new awareness, the driving force which has led governments, the media and the general public to concern themselves, not only with the depletability of oil - although this resource is at present in the foreground - but with the whole spectrum of the world's exhaustible natural resources. For the industrialized countries this is a concept which they will not find easy to adopt, but it is unavoidable if we are not to be confronted in the foreseeable future with an energy gap, the economic, social and political consequences of which hardly bear contemplation. OPEC has always been ready to play its full part in creating a better world for all of us to live innot only through the bridging of the gap between the oil age and that of alternatives but also and mainly, through the closing of that other gap between developed and developing countries. ${ }^{365}$

\section{Blowback from OPEC's price hikes and the collapse of its market share domination}

Beneath the surface of anxiety and concern regarding the continual tightening and sporadic disruption of supply in many advanced economies, all the while OPEC and its producer counterparts rested on the inevitability of higher demand and higher prices, were forces that would fundamentally alter the nature of the global oil industry. Out of the all the countries that had suffered from the 1970s supply disruptions and price increases, it was arguably Japan, an island nation with little to no crude oil, that had felt the most vulnerable. The predicament surrounding Iranian exports was only the latest crisis to highlight Japan's oil vulnerability. ${ }^{366}$ But Japan was not just reacting to events. It had engaged in a multi-national effort of energy diplomacy, sending representatives to several Latin American and African countries, with a specific emphasis on Mexican crude. ${ }^{367}$ By 1980, Japan's energy policy rested on three principles: expand conservation

\footnotetext{
${ }^{365}$ OPEC, Opec Official Resolutions and Press Releases 1960-1990, 185.

${ }^{366}$ Donald W. Klein, "Japan 1979: The Second Oil Crisis," Asian Survey 20, no. 1 (1980).

${ }^{367}$ Ibid.: 43-44.
} 
efforts, diversify sources of energy from oil to alternatives such as coal, nuclear power and natural gas, and divert dependence from the Middle East to more secure sources of supply. ${ }^{368}$ Though this was essentially the model that most of the advanced economies followed - initially sketched out in 1975 - Japan had by the early 1980s advanced the most, primarily because of necessity.

However, the second oil shock truly brought about a new phase in Japan's quest, started years prior, to lead in conservation efforts, of which automobiles were the most consequential. As Koichi Shimokawa has catalogued, the US automobile market, from 1980 to 1983, witnessed a major shift in demand for the fuel-efficient and compact automobiles, the very same kind that Japan was mastering for the home market. ${ }^{369}$ With time, spawned by the first and second OPEC shocks, the very nature of personal transport had shifted, from the large and heavy gas-consuming automobile, to the smaller, more efficient vehicle. It was at this time that demand for Japanese autos skyrocketed, penetrating other advanced, free market economies.

Compounding this trend was the conservation efforts making headway in North America and Europe. As Figure 4.2 shows, North American consumption in 1979 was roughly $21.3 \mathrm{mbpd}$, but for the next decade it would continuously drop. The lowest figure came about in 1983 at 17.95 mbpd. By 1993, North American oil consumption was only $20.6 \mathrm{mbpd}$, lower than its 1979 figure. Europe's conservation attempts were even more dramatic. Though the continent's 1979 figures were $24.7 \mathrm{mbpd}$, by 1993 those figures had declined to $20.6 \mathrm{mbpd}$. And adding to the efficacy of the conservation efforts was the

\footnotetext{
${ }^{368}$ Valerie Yorke, "Oil, the Middle East and Japan's Search for Security," International Affairs (Royal Institute of International Affairs 1944-) 57, no. 3 (1981): 428.

${ }^{369}$ K. Shimokawa, The Japanese Automobile Industry: A Business History (Bloomsbury, 1994), x-12.
} 
fact that alternative sources of crude was now coming online. Although US production was in steady decline (from $10.1 \mathrm{mbpd}$ in 1979 down to $8.9 \mathrm{mbpd}$ ), the North Sea, Canada, and Mexico made substantial contributions in the West's alternatives strategy. ${ }^{370}$ Canada's 1979 figures jumped from $1.8 \mathrm{mbpd}$ to $2.2 \mathrm{mbpd}$ in 1993. In the same time frame, Mexico increased from $1.6 \mathrm{mbpd}$ to $3.1 \mathrm{mbpd}$. The North Sea's output, mostly seen in the British and Norwegian production, was also significant. Britain's 1979 figures went from $1.6 \mathrm{mbpd}$ to $2.0 \mathrm{mbpd}$ while Norway's 1979 output increased from a modest 407,000 bpd to $2.4 \mathrm{mbpd}$. And all of these smaller changes were happening as Iran and Iraq were locked in an incredibly destructive conflict that, throughout the $1980 \mathrm{~s}$, devastated the production capacities of both countries.

Figure 4.4: Shares of global oil production between OPEC and non OPEC producers: 1978-1993 Source: OPEC Statistical Data. http://www.opec.org/opec_web/en/data_graphs/330.htm

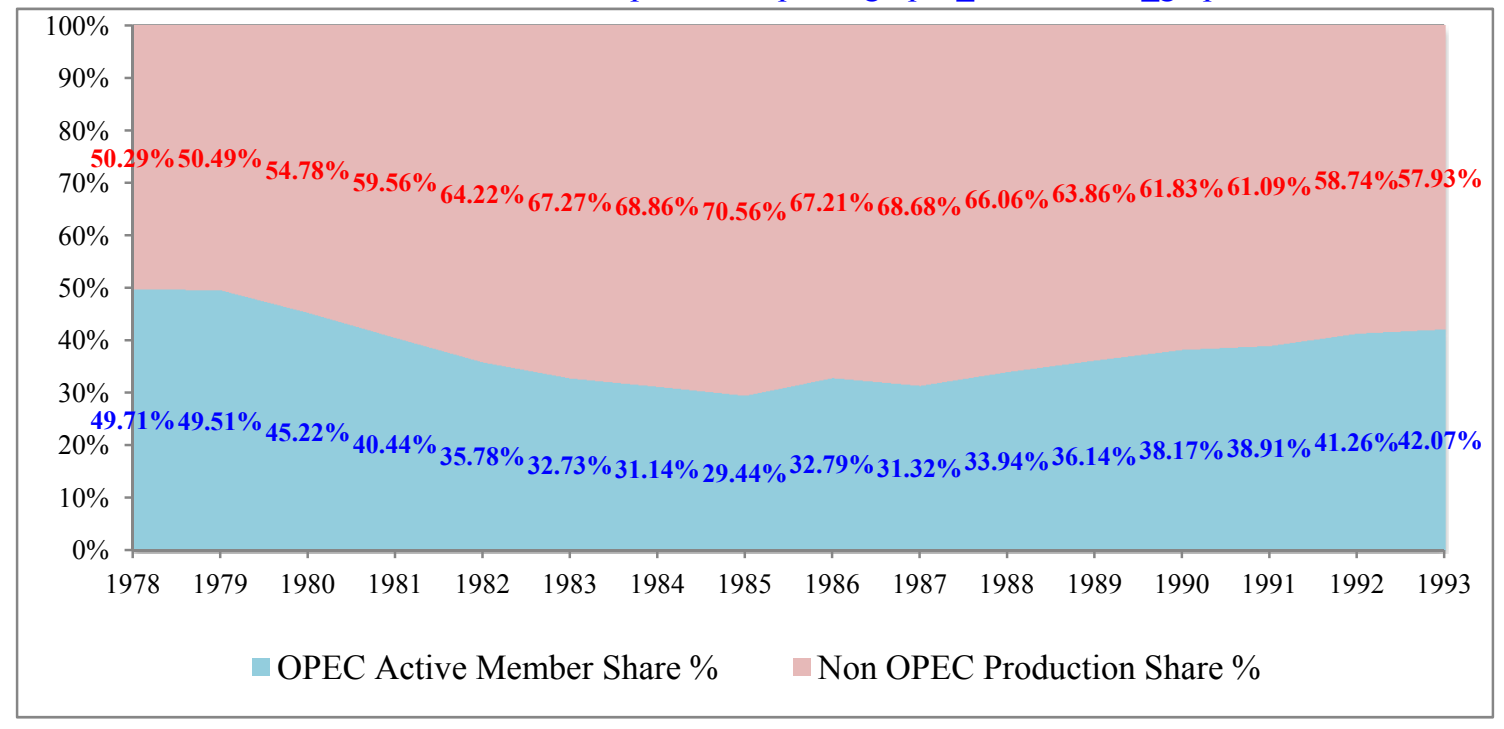

The results - amplified by OPEC's internal strife (conflict between Iran and Iraq while later Iraq and Kuwait) and the Organization's broader inability to protect its longsought after preeminent position in the global economy - was the massive weakening of

${ }^{370}$ See: BP Statistical Review of World Energy June 2013 
OPEC's market share domination. As Figure 4.4 clearly shows, OPEC's percentage of global oil production dramatically fell from its 1979 figure of $49.71 \%$ to $40.44 \%$ in 1981 . And as will be discussed in subsequent sections, the inability of the Organization to address the conflict between Iran and Iraq, its further paralysis as conflict led to open War between the two founding Member States, and the ramifications of that conflict on other Member States (and their relations amongst each other) only further weakened the cohesion of the OPEC, and thus its ability to maintain market share control.

\section{Intrastate Dynamics}

The beginning of the Fragmentation phase began within and remained deeply affected by the internal dynamics of three distinct places: Iran, Iraq, and the Persian Gulf Arab Sheikhdoms of OPEC, specifically Saudi Arabia, Kuwait, and the UAE. The collapse of the Shah's regime, the precedent that this event set for other States in the region and beyond, and the rise of Political Islam in the shape of the Islamic Republic political system both remade the political architecture of the Middle East and changed the internal functionality of OPEC. This process of fragmentation within the Organization was not, however, in the span of days, but took almost two years to fully become visible, began gradually in the immediate aftermath of the Shah's departure of January of 1979, throughout that year and the next, and reaching its official beginning in September of 1980 , as the Iran-Iraq War commenced.

\section{Revolutionary Iran and the establishment of the Islamic Republic}

While the most consequential impact of Iran's political upheaval was ultimately political and geostrategic in nature - in that it fundamentally reshaped the security architecture of 
the Middle East and challenged the Cold War binary of the time by introducing Political Islam as a third, alternative political model - it's initial impact on OPEC and the global political economy was economic. This happened primarily in two theatres. The Revolution caused a dramatic decline in Iranian oil production at a time when the market supply was tight and the potential for market panic on supply disruption was particularly vulnerable. The now established concern over exhaustibility was only supplemented by new concerns over unintentional supply disruptions. The collapse of the Shah's once powerful regime, in a major producing country, only brought this concern further to home.

Secondly, one of the first major acts of the provisional government and carried through after the official establishment of the Islamic Republic was the full nationalization of Iranian oil. This move was later codified under Article 3 of the new Iranian Constitution drafted after during the provisional period before the official establishment of the Islamic Republic and ratified in 1980. ${ }^{371}$ This meant that the Consortium - long a thorn in the side of the Shah and effectively sidelined in major aspects of Iranian production and price controls during the negotiations - had now officially been dismantled by the new Iranian government. Having such a full-scale nationalization happen, even when events of state appropriation were no longer novel by the early 1980s, still exacerbated the already shaky nerves that diverse markets had regarding global supply disruption.

But events would gradually take on a far more political and later, security significance. The hostage crisis surrounding the storming of the US embassy and taking

\footnotetext{
${ }^{371}$ Marcel and Mitchell, Oil Titans: National Oil Companies in the Middle East, 30-31.
} 
of American personnel by Iranian students had dramatically and negatively changed the image of both Iran's Revolution and its new government in the eyes of many states, particularly those in the West. Though this event greatly assisted in the creation of a 'menacing' and 'rogue' revolutionary leadership within Iran, the fundamentals behind the major changes in the Iran-US relationship went much than the hostage crisis. Indeed, the collapse of Iran-US relations had its roots in the trends that were forming in the decades prior to 1979 , which by this time were now clashing.

The patron-client relationship that had developed in the aftermath of the 1953 coup against Mossadegh, the contradictory situation of the Shah's intense need for this relationship all the while loathing the existence of it, and the severe and escalating differences that the Iranian state, under the Shah, had with the US regarding oil prices, created the conditions for the explosion of acrimony between both sides. With the Shah's departure, the weeks and months that passed witnessed the US moving from paralysis caused by confusion concerning the Shah's demise, to tactically recognizing the provisional government all the while US policy was in disarray towards Iran, to becoming vehemently opposed to the leadership that would eventually become the Islamic Republic. And with this new opposition, came the first and continuous signs of economic Warfare against Iran, in the form of trade, financial, and other economic sanctions and embargoes against Iran. ${ }^{372}$

The political disarray in Iran, exacerbated by the isolation that the country was entering in the immediate aftermath of the Revolution, only further weakened Iran's oil

\footnotetext{
${ }^{372}$ H. Askari, Case Studies of Us Economic Sanctions (Praeger, 2003), 177-244.
} 
production capacity, thus creating the conditions where other potential rivals would take the dominant place in decision-making and leadership that Iran once had within OPEC.

\section{Persian Gulf Arabs React: From Relief to Fear}

For the monarchies of the Persian Gulf Arabs, Iran's political upheaval was initially seen not as a threat, but cautiously accepted. This was clearly demonstrated in an interview that King Fahd of Saudi Arabia, then the Crown Prince, made to Al-Hawadith. ${ }^{373}$ And as King Fahd mentioned within that interview, Iran's notion of pan-Islamic unity, a marked change from the Shah's rhetoric, was initially welcomed. But more importantly, the Saudis and others in the region realized that, at least for the time being, the Revolution had weakened Iran and put its economy and military in flux - to the point that they no longer, at least in theory, could be seen as a threat to the Saudis and other Persian Gulf states.

But as the months progressed from the Revolution, gradually, the perception of these sheikhdoms dramatically changed towards Iran's political change and new government. Political Islam's rise in Iran, in the Saudi perception, because it had empowered the clerical establishment of the largest Shia Islamic country in the world, set a dangerous precedent for countries with sizeable Shia communities in the region. ${ }^{374}$ For the Arab sheikhdoms, this proved to be a precedent that not only could and eventually did cause varying degrees of political instability within their countries, but had the potential to threaten the survivability of their regimes. With the perception of the Iranian

\footnotetext{
373 "Al-Hawadith Interviews Crown Prince Amir Fahd," London AL-HAWADITH 1980.

${ }^{374}$ See: F.G. Gause, Oil Monarchies: Domestic and Security Challenges in the Arab Gulf States (Council on Foreign Relations Press, 1994), 32-33. A.H. Cordesman, Center for Strategic, and International Studies, Saudi Arabia: National Security in a Troubled Region (Praeger Security International, 2009), 21-22.
} 
Revolution now changing from an opportunity to capitalize on Iranian weakness via the distractions of upheaval to a threat that no longer could be ignored, there arose an integrated strategy that Persian Gulf Arabs embarked upon to keep revolutionary instability at bay. The most consequential was the creation of Gulf Cooperation Council (GCC), in which security, strategic, and economic policy could be streamlined in a more unified position, mainly because of the threat that Revolutionary Iran posed. ${ }^{375}$

\section{The Third Baathist State: Opportunity spurns War}

Within Iraq however, the continuance of Iran's revolutionary instability was simultaneously seen as both an opportunity and a threat, as opposed to devolving from one perception to another. On the latter, the newly empowered, and but significantly leaner Baath party in Iraq, having been purged of any potential political rivals to Saddam Hussein, saw Iran's political instability as a chance to remake, in Iraq's favor, the territorial and political disputes that Baghdad long had with its powerful Eastern neighbor. It's important to remember that these disputes, particularly the territorial ones, were issues that for decades had proven a spoiler in the larger Iranian-Iraqi relationship, some of which going back to the immediate aftermath of Iraq's 1958 Revolution that overthrow the Iraqi monarchy. ${ }^{376}$

Moreover, Hussein's territorial disputes with Iran, particularly his intermittent calls to annex the Iranian province of Khuzestan, had much to do with oil. Khuzestan's oil deposits were and still are extremely vast. Thus, the irredentists claims of the Iraqi

\footnotetext{
${ }^{375}$ H. Askari, Conflicts in the Persian Gulf: Origins and Evolution (Palgrave Macmillan, 2013), 1-20.

${ }^{376}$ Will D. Swearingen, "Geopolitical Origins of the Iran-Iraq War," Geographical Review 78, no. 4 (1988): 405-16.
} 
Baath had just as much to do with their national perceptions of what constitutes their territory, as it did with the significant economic benefits that they would accrue if some of these claims actually came into fruition.

Yet, what exacerbated the cycle of animosity was the fear from Saddam's regime of the mass political empowerment of the Iraqi Shia, the majority of Iraq, by reason of the rise and establishment of the Islamic Republic next door. ${ }^{377}$ This was particularly acute as the religious bonds between both countries, particularly between the Iranian city of Qom and Iraq's Karbala and Najaf, had traditionally been quite strong. With the arrival of the Baath in political power in Iraq, these bonds were initially downplayed, only later to be cut. Accordingly, the Iranian Revolution was seen by Saddam's regime as a threat to his rule as well, and eventually far more acute of a threat than the other neighboring states of the Persian Gulf.

\section{Interstate Relations}

Once these assessments from both Iraq and the monarchies of the Persian Gulf fully crystallized, the fear concerning Iran dramatically converged their interests and strategic approaches to the political realities in Iran and what that would mean for the wider region. As 1981 approached, the internal functionality of OPEC - paralyzed since the immediate aftermath of the Iranian Revolution and its inability to respond to the ensuing pricing crisis - would now begin the process of fragmentation, only to completely disintegrate in its functionality near the end of the 1980s

\footnotetext{
${ }^{377}$ J. Donovan, The Iran-Iraq War: Antecedents and Conflict Escalation (Taylor \& Francis, 2010), 86-102.
} 


\section{The beginnings of the Iran-Iraq War}

The September 1980 Iraqi invasion of Iran was the first real instance where a Member State went to War with another Member State. Though Iraq and Kuwait, in the early weeks after OPEC's founding, did escalate their territorial disputes, potentially leading toward open hostilities, the Iran-Iraq War was qualitatively different. By the time the Iraqi Baathist government decided to launch the invasion of Iran, the dividing lines, both within OPEC, and beyond were already drawn.

Sensing the fear that the Persian Gulf Arab monarchies had of revolutionary instability penetrating their borders, Saddam's War plan against Iran, from the very onset of hostilities until the end of the War, relied upon significant financial assistance from his southern neighbors. In initially citing Revolutionary Iran's interference in Iraqi affairs, specifically as it relates to aid given to Iraqi Kurds, and its purported violations of the Algiers Accord both countries signed in 1975, which was intended to resolve their border issues, Saddam initiated the war while Iran's political dynamics, economic position, and military posture were chaotic and fluid. ${ }^{378}$ Iraq's opening salvo against Iran was successful due to the latter's inability to foresee the scale of the Iraqi invasion, although relations had dramatically worsened by then and throughout the year had seen localized instances of border violence. Furthermore, the support garnered by the Baathist regime from other significant players in the Arab world, outside of OPEC, added to the confidence of Saddam's regime in his war efforts. With some notable exceptions, such as Libya and Syria (with Lebanon's neutrality) the greater part of the Arab World, the Arab

\footnotetext{
${ }^{378}$ E. Karsh, The Iran-Iraq War (Rosen Pub., 2009), 11-13; F. Rajaee, The Iran-Iraq War: The Politics of Aggression (University Press of Florida, 1993). Rajaee, The Iran-Iraq War: The Politics of Aggression, 1123.
} 
League in particular, openly supported and assisted Iraq during the War. In those initial weeks of open hostilities, the Iraqi regime had assured itself of a quick victory over Iran. If victory had arrived when Baghdad expected it, not only would Iran's Khuzestan province be occupied by Iraqi forces, but the future of Iran's role in OPEC, and possibly that of its political orientation would have been significantly influenced by the IraqiPersian Gulf Arab coalition that had come out so antagonistically against Revolutionary Iran.

\section{The failure of OPEC to broker peace}

While the Iraqi Baath were able to garner the overt support of every Arab OPEC member and the brunt of the Arab League, the rest of OPEC's Member States had no real coherent policy or approach to the Iran-Iraq War. The initiation of hostilities between two of OPEC's founding Members and the subsequent polarization within Group, created a sense of paralysis amongst other Members. Though the conflict would eventually have dramatically negative affects upon the Organization, as any open hostility among Members would lead to the weakening of OPEC (which would be deleterious for Member States), there was very little public effort made to first acknowledge the conflict or even contain it. Finally, the Organization, in their $59^{\text {th }}$ conference in December 1980 , did acknowledge what had greatly contributed to the massive crude oil price increase of the past few weeks, namely the War between Iran and Iraq:

The Conference endorsed the sincere and honest appeal made by His Excellency the President of the Republic of Indonesia in his inauguration speech to the two Member Countries - Iran and Iraq - who are presently in dispute, to quickly seek the best possible solution to their conflict leading to a peaceful settlement of their differences. ${ }^{379}$

${ }^{379}$ OPEC, Opec Official Resolutions and Press Releases 1960-1990, 192. 
Yet, with the exception of this acknowledgement, OPEC, as an institution, either volitionally or by force, ignored the War. For all of 1981, the Organization, in its Resolutions, chose to focus on procedural and personnel matters. As prices began to erode that year, only to plunge significantly, not only was OPEC still adhering to the exhaustibility theory but also was unable to address the escalating conflict between Iran and Iraq. As the War increased, it gradually weakened the influential power of both Members within the Organization, as production capacity lessened both States' influence in decision-making. However, for OPEC, the War that would eventually cripple the production capacities of these two significant exporters would also become deleterious to the Organization's future.

As the War would drag on, OPEC's capacity to act on behalf of its Members and respond to Market Forces would be significantly debilitated, as the loss of collective OPEC output would affect the market share that took more than two decades to build. The collective inability of OPEC to bring about a halt to the War - particularly in the first few months - ultimately created the conditions for the War's continuance, and significant damage it levied on the Organization's unity, functionality, and place in the global economy.

\section{Outside Powers}

By the time the Iran-Iraq War commenced and well into the first year of hostilities, Washington's animosity towards Iran had largely hardened. The hostage crisis, the "loss of Iran" in American grand strategy, and the birth of a new Iranian foreign policy that 
clashed in direct ways with established US policy preferences for the Middle East and the wider oil industry, only worsened the relationship. By 1981, fear of Revolutionary Iran and how that would affect the strategic interests of the US moved Washington to gradually open up relations with Saddam Hussein's Iraq, a relationship that had largely remained frozen since the mid-1970s. Baathist Iraq, both under Al-Bakr and then under Hussein, remained firmly in the Soviet Camp, relying on Soviet patronage and assistance for technical assistance with its oil industry, weapons purchases, and mega infrastructural projects. ${ }^{380}$

However, with the Iranian Revolution, the US found itself supporting the same side that the Soviets had long cultivated and endorsed, which Moscow only expanded in support in its conflict with Iran. ${ }^{381}$ As Adam Tarock has aptly chronicled, the approach of the great powers with their respective support to the combatants of this conflict can be clearly seen and analyzed by their behavior at the United Nations Security Council (UNSC). ${ }^{382}$ Tarock points out that, in response to the Iraqi invasion of Iran, it took 4 days for the UNSC to meet, as opposed to what will later be discussed, the Iraqi invasion of Kuwait in August of 1990, in which the UNSC met on the same day. ${ }^{383}$ More importantly, the UNSC's adoption of Resolution of 479, which called for a ceasefire between both sides, was implemented after Iraq had occupied large swaths of Iran's

\footnotetext{
${ }^{380}$ G. Golan, Soviet Policies in the Middle East: From World War Two to Gorbachev (Cambridge University Press, 1990), 157-75.

${ }^{381}$ Mohiaddin Mesbahi, "The Ussr and the Iran-Iraq: From Brezhnev to Gorbachev," in The Iran-Iraq War: The Politics of Aggression, ed. F. Rajaee (University Press of Florida, 1993), 69-103.; Oles M. Smolansky and B.M. Smolansky, The Ussr and Iraq: The Soviet Quest for Influence (Duke University Press, 1991), 230-80.

${ }^{382}$ Adam Tarock, The Superpowers' Involvement in the Iran-Iraq War (Nova Science Publishers, 1998), 74-76.

${ }^{383}$ Ibid.
} 
Khuzestan province, and yet made no demands to the Iraqi's to withdraw. ${ }^{384}$ The UNSC inability to function, as R.P.H. King has argued, was formed by the confluence of its Members' deference to their individual national interests, ${ }^{385}$ of which for the US in particular was shaped by the Iranian hostage crisis, while for the Soviets it was the fundamental aversion to Political Islam. After the Iranian's rejected the UNSC resolution, it would take another two years for the Council to revisit matter.

Indeed, the conflict between Iran-Iraq was the first and only major war since the beginning of the Cold War that Washington and Moscow not only supported the same side, but fundamentally for the same reasons: the containment and eventual extinguishing of the revolutionary upheaval that flowed from Iran. The possible ramifications of the spread of this political upheaval to other countries - regardless of a particular country adopting a political model that took root in Iran - would rapidly erode the binary of American and Soviet strategic power in the region. But as the Soviets merely expanded the relationship they had with Baghdad to counter Iran's War making abilities - primarily by assisting with weaponry and training - the US position evolved from secret communications, to logistical intelligence sharing, to weapons transfers, to official recognition and normalization of relations, to full-throated open support for the Iraqi War effort. And this process started in earnest only months after the beginning of hostilities.

\section{Fearing Revolutionary Iran, the US starts recognition and cooperation with Iraq}

In April of 1981, after completing his first overseas trip as Secretary of State (which was to the Middle East), Alexander Haig conveyed a message to Iraq's Foreign

\footnotetext{
384 Ibid.

${ }^{385}$ R.P.H. King, U.N. And the Iran-Iraq War (Diane Publishing Company, 1987), 7-10.
} 
Minister Sa'dun Hammadi in order to test the grounds of any possible convergence of interests between the US and Iraq. ${ }^{386}$ In his correspondence to Hammadi, Secretary Haig highlighted that he would be sending Deputy Assistant Secretary of State Morris Draper to Baghdad for consultations with the Iraq government on a variety of issues. Haig's intention was to convey to the Foreign Minister that both the US and Iraq needed to be "able to exchange views, freely and on a systematic basis", as there were issues that united and divided both sides, but ultimately geared to "come to understand more fully the views of one another". ${ }^{387}$

Only a few days before Haig's outreach, the US interests section in Baghdad sent an analysis on the possibility for better US-Iraqi relations. In the dispatch, the analysts remarked that Draper's coming visit to Baghdad was the first visit by a senior American official since 1977. ${ }^{388}$ The US analysts further stated that Washington's decision to embargo Iran, chiefly as it relates to the selling of arms, had been well received and had positively shifted the mood of Iraq's officials about the US. ${ }^{389}$ More significantly, they remarked that the US had now a "greater convergence of interests with Iraq than at any time since the Revolution of 1958." ${ }^{390}$ For the US, an upgrading of relations with Baghdad, though it would take time, was Warranted, because of the altered regional dynamics, of which Iran's political transformation was the most important. As Iraq's

\footnotetext{
${ }^{386}$ Secretary's Message to Iraqi Foreign Minister, 17 April 1981, folder "Iraq: 1/20/81-12/31/81 [3 of 4]" Box 37, Executive Secret Records. Ronald Reagan Presidential Library.

${ }^{387}$ Ibid.

${ }^{388}$ Dispatch from American Interests Section-Baghdad, 7 April 1981, folder "Iraq: 1/20/81-12/31/81 [3 of

4]" Box 37, Executive Secret Records. Ronald Reagan Presidential Library.

${ }^{389}$ Ibid.

${ }^{390}$ Ibid.
} 
Foreign Minister returned a cordial yet brief communication to Secretary Haig, ${ }^{391}$ the stage was set for the gradual improving of relations, which was most importantly manifested with senior officials meeting with each other. The most significant was William Eagleton's meeting with the then current head of Iraq's Revolutionary Command Council and future Foreign Minister Tariq Aziz, which was highest-level meeting with an official from Iraqi government since the collapse of relations in $1967 .{ }^{392}$ As dialogue intensified between Washington and Baghdad, both sides gradually began to talk about Iraq's acquisition of the more sophisticated US weapons that would assist it in the War with Iran. By mid-1981, any hope that Baathist Iraq had about a quick victory against Revolutionary Iran had long dissipated. At this point, it was the Iranians who were on the offensive, slowly repelling the Iraqis out of Iranian territory. Yet, for the US to fundamentally offer and deliver tangible help for the Iraqi War effort, there needed to be a normalization of Iraq, by the US, in the international community. In other words, Iraq could not be seen any longer as a "rogue" nation but on that had good standing among other countries. The reputation that Baghdad had long held was of a Soviet client state, a leader of the reactionary Arab states against Israel, and an oil price hawk. Most significantly, the US and the West in general, had concerns about Iraqi support for terrorist groups, and as such, Baghdad was designated a state sponsor of terrorism.

What this meant was that the US government, could not transfer weaponry, aid, training for the Iraqi military, or any meaningful interstate security cooperation and

\footnotetext{
${ }^{391}$ United States Department of State, 15 April 1981 "Iraq Ministry of Foreign Affairs Letter from Saadoun Hammadi to Alexander M. Haig, Jr. [Iraqi Minister for Foreign Affairs Praise for Visit of Under Secretary Draper].

${ }^{392}$ United States Department of State, 28 May 1981, United States Interests Section in Iraq Cable from William L. Eagleton, Jr. to Department of State. "Meeting with Tariq Aziz".
} 
commerce with relative ease. More so, the US would be breaking its own laws. But as the US would shift towards Iraq, Washington would take the steps to remove Iraq from this list. And after a series of negotiations with Baghdad, in early 1982 the US decided to ultimately delist Iraq from the list of countries deemed state sponsors of terrorism. ${ }^{393}$

Although US officials still had deep suspicions about Iraq's continued sponsorship of certain regional militant groups, ${ }^{394}$ once this delisting occurred, relations broadened on significant political, security, and economic issues. This resulted in more frequent communications with very senior personnel of both countries and Iraq's broader access to the American economy and military technology. Near the end of 1982, US-Iraqi relations, though not able to be described as an alliance, were now well on its way to becoming normalized. But unlike other instances of diplomatic normalization with the US government, this process with Iraq was significantly fastracked because of the converging concerns regarding Iran.

\section{Iranian gains in the Iran-Iraq War}

At the same time, the Iran-Iraq War, which in the opening weeks was going well for the Iraqis, had by the end of 1982 witnessed several Iraqi setbacks and Iranian victories. From the time of the invasion to the end of 1982, a series of Iraqi miscalculations regarding Iran's military strength and its response to the Iraqi invasion, Iraq's military planning as it pertains to offensive strategies, and the ability of the new Iranian

\footnotetext{
${ }^{393}$ United States Department of State, 27 February 1982. Department of State Cable from Alexander M. Haig, Jr. to the United States Interests Section in Iraq. "De-designation of Iraq as Supporter of International Terrorism".

${ }^{394}$ United States Department of State, 14 December 1983, 23 May 1983, Department of State Cable from George P. Shultz to the United States Interests Section in Iraq. "Message from the Secretary for FON MIN Tariq Aziz: Iraqi Support for Terrorism".
} 
government to garner significant military ability to resist the invasion, eventually collapsed Iraq's initial war plans. Hussein's rational was that Iran would be so consumed with political disarray, because of the arduous process of building a functional central authority that it could not push back against a well-equipped and cash-laden Iraqi army. Furthermore, the severing of Iran-US relations left Iran fully exposed to aggression from Iraq and other states, as Iran no longer had a great power to rely upon for military hardware, technology, and diplomatic protection.

But with time, Saddam's calculations simply did not materialize. Though the Iraqi military, in the opening weeks of the war, was able to push significantly in Iran's Khuzestan province, and threaten surrounding provinces, the Iraqi invasion became far more a galvanizing factor to the various political currents in Iran jockeying for power. In essence, the war assisted in the bureaucratic centralization of the new government, by reason of the war effort being the most significant large-scale project that Tehran had to contend with. As the core of the traditional Iranian military became functional again, along with the newly created Revolutionary Guard, and the volunteer Basij forces, Iran slowly began to restore balance to the dynamics of the conflict.

The most important and consequential Iranian victory in the early years of War was the liberation of Khorramshahr, a vital Iranian port city on the Persian Gulf that the Iraqis had captured in the immediate weeks after their invasion. Iraq's army lay ruin to city and the surrounding areas because the importance of the city to Iran's overall trade with the outside world, both regarding oil exports via shipping and other non-oil commerce. The Iraqi Baath believed that with the destruction and occupation of Iran's major ports, the population would suffer extreme hardships because of the lack of trade, 
and would thus pressure their government to sue for peace under terms favoring Iraq. For more than a year and half, Khorramshar was occupied by the Iraqi Baath army. In that time, Saddam's forces looted most if not all of the imported cargo that was destined to reach other Iranian cities, and commodities that were meant for export to foreign markets. Intermittent shelling of Khorramshahr by both sides destroyed large parts of the city.

However, in April of 1982, Iran began the initial phases of a counteroffensive that would recapture this vital port city, and turn the tide of war in its favor. By May of 1982, Khorramshar was retaken by Iran. Shortly afterwards, the Iraqi military was essentially pushed out of Iran, and forced to defend Iraqi territory from an emboldened Iranian military, with a determined, albeit inexperienced, Iranian leadership. With the recapturing of Khorramshar, Iraq's military began to make a series of mistakes that further advantaged Iran in the War.

\section{America's policy shift towards over assistance to Iraq}

From the US position, the prior two years had been dedicated to building it relations with the Iraqi Baath. From offering a diplomatic makeover to Saddam Hussein's regime, to providing modest weaponry, to contributing in more robust intelligence sharing, and economic normality between the two countries (even before there was political normality), the US policy of outreach to Baghdad had largely succeeded. The US and Iraq were not only on speaking terms, but now tactically in agreement as it related to Iran. However, as Iran's advanced in its war aims with Iraq - from strictly a defensive posture to an offensive strategy - the US increasingly feared the possibility and the ramifications

of an Iranian victory in the war. After the tide had turned in the expulsion of the Iraqi 
military from Iranian territory, the US, under the Reagan administration, undertook a series of policy revisions that would have consequential and lasting impact on the war, OPEC's functionality, and the political future of the broader Middle East.

In early 1983, the US began a series of internal policy reviews on several factors as it related to the war, the most important of which was the following: the ramifications of an Iranian victory, the ramifications of what a prolonged conflict would have on oil prices (which were decreasing at the time), and the ramifications of the regionalization of the conflict. Each scenario was seemed highly negative towards US interests and should be avoided at all costs. In policy reviews that were conducted by varying American agencies, it was agreed upon that the US position of de-facto 'neutrality' - as it was described by US policy makers (even though the US was slightly assisting one side while sanctioning another) - was no longer tenable.

In other words, the continuation of the Iran-Iraq war without overt American involvement in the substantial aiding of Iraq (which would purportedly end on terms favorable to Baghdad) would inevitably lead to either one, some, or all of the above mentioned scenarios. The clearest indication of the this strategic shift to overt US involvement in the aiding of the Iraqi Baath was a memo written by top diplomat and future US Secretary of State Lawrence S. Eagleburger. In the memo, Eagleburger lays out the fundamental US rationale for what 'neutrality':

When the war began three years ago, our poor relations with both combatants and concern for our security interests in the Gulf led us to reinforce air defenses by the deployment of AWACS to Saudi Arabia and to block the use of air bases in the Arabian Peninsula by Iraqi aircraft to reduce the threat of expansion of the war. Our neutrality policy evolved out of this preventative reaction. Until now, this policy has served our objectives and interests well. It has: avoided direct great power 
involvement; prevented spread of the war beyond the territory of the combatants to threaten Gulf oil supplies; contributed to the current military stalemate; preserved the possibility of developing a future relationship with Iran while minimizing openings for expansion of Soviet influence. ${ }^{395}$

However, as Eagleburger sketches out, the strategic environment where that policy was developed had now changed dramatically. Behind that change, two critical developments lay at the foundation: the extensive improvement of bilateral relations with Iraq as relations with Iran continued to "be virtually non-existent" and how Iran's strategy of "bringing about the Iraqi regime's political collapse through military attrition coupled with financial strangulation" was "slowly having an effect". ${ }^{396}$ The conclusion was broader than the possibility of Iraq being forced to look towards other weapons suppliers, thus internationalizing the conflict by bringing in great power competition. The real fear that Eagleburger and the State Department characterized as being "seriously adverse to [American] interests" was the escalation of the then limited Iraqi campaign of targeting Iran's oil infrastructure, was targeting Iran's revenue.

For the US, the loss of control of these tactics by Baghdad risked an escalation that would elicit an Iranian backlash which "could cause Iran to try to prevent through force all oil exports" from the Persian Gulf. ${ }^{397}$ The US feared that Iraq's attack on Iran's war making ability (i.e. its oil profits via the selling of crude) would inadvertently lead to major supply disruptions, leading to a loss of Iranian, Iraqi, and other Persian Gulf oil.

\footnotetext{
${ }^{395}$ United States Department of State, Bureau of Near Eastern and South Asian Affairs Information Memorandum from Jonathan T. Howe to Lawrence S. Eagleburger. 7 October 1983. "Iran-Iraq War: Analysis of Possible U.S. Shift from Position of Strict Neutrality".

${ }^{396}$ Ibid.

${ }^{397}$ Ibid.
} 
Earlier that year, the Department of Energy released a memo warning about the effects of the closure of the Strait of Hormuz, the pivotal water way that is the sole exit from the Persian Gulf. The Department of Energy concluded that the closure of the Strait could lead to a loss of 10 mbpd of the market and advocated for actively reaching out to other regional producers, including major OPEC Members, to offset the possibility of this supply disruption. ${ }^{398}$ The concern over supply disruption from the region was coupled with what Eagleburger and the State Department portrayed as the possibility of "sustained Iranian pressure" bringing “about Iraq's political collapse." ${ }^{399}$ In other words, the US had a heightened assessment of the destructive power of the Islamic Republic while fearing the potential weakness of the Iraqi military.

With this assessment, the building blocks of the US response to the remainder of the Iran-Iraq war were laid down. What the State Department proposed was to assist Iraq in three interconnected ways: financial, diplomatic, and militarily, of which the former two would become the most substantial. On the financial aspect, the most consequential feature of this assistance was the conscious American decision to upgrade Iraq's oil exports, while it was in the process of cutting out Iranian oil from the global economy. This overt decision by the US would become the most far-reaching intervention in the internal functionality of OPEC since the Organization's creation.

In times past, particularly the 1960s, the US intervention in OPEC's affairs was far more circumspect and behind the scenes. Now, with the proposed upgrading of Iraqi

\footnotetext{
${ }^{398}$ Department of Energy Memo, 26 August 1983, folder “Iraq” Box 4,5,6,7, William F. Martin Records. Ronald Reagan Presidential Library.

${ }^{399}$ Department of State. 7 October 1983. "Iran-Iraq War: Analysis of Possible U.S. Shift from Position of Strict Neutrality".
} 
exports, while Washington waged economic warfare against Iran, thus targeting Iran's ability to produce and sell, these actions were difficult to deny or ignore. More so, to fundamentally cause an upgrading to Iraqi output and excess capacity would be to regionalize the conflict with Iran and Iraq, as the latter, as the State Department attests, would need active assistance from the Arab monarchies of the Persian Gulf. This was the most relevant as it relates to Iraq's quest for more pipeline distribution across the Arabian Peninsula and potentially involving Syria.

Diplomatically, the proposition was for the US to continue and possibly expand a greater role at the UN in bringing hostilities to an end, while also issuing "more explicit statements of support for the territorial integrity of Iraq and the survival of its present government." ${ }^{400}$ Albeit, this would come at a cost, as it would openly confirm US support for Baathist Iraq, a reality not lost on US decision makers. Militarily, though the economic warfare against Iran was to continue, it was to be broadened to disrupt the foreign military hardware that Iran was managing to still obtain, regardless of the sanctions placed on its economy.

As Figure 4.5 shows, Iran's post-revolutionary ability to secure outside military technology all but collapsed. With the exception of a few countries, Iran's access to foreign sources of military hardware, technology, and maintenance was solely dependent upon the West, chiefly the US. But with the erosion of Iran-US relations in the wake of the Revolution, the hostage crisis, only to be exacerbated by the war, Iran found itself completely cut off from traditional partners. It was thus forced to purchase lower quality hardware with older technology or pay exorbitant fees for what it used to have access too,

\footnotetext{
${ }^{400}$ Ibid.
} 
oftentimes relying on third parties that went through the global black market.

At the same time, the US developed a more robust export policy vis-à-vis Iraq. In lieu of the US actually committing American forces to fight on behalf of Iraq against Iran, it helped facilitate much wider access to military technology. However, it is important to note that while there was a modest increase in direct, state-to-state, arms transfers from the US to Iraq, it was the financial and diplomatic changes to US policies (i.e. sanctions removal, access to cross-border technology, diplomatic normalcy and protection to Iraq, etc.) that helped facilitate other countries providing and selling the Iraqis weapons for their war effort (see Figure 4.6). Thus, the military aspect of US assistance to Iraq, in and of itself, was very minimal. This was because of the many hurdles it took in the early months of the war to normalize the Iraqi Baath as a US partner, but more importantly, normalize Iraqi-US relations. Only with the normalization of Iraq in the international system via its newfound relationship with the US, did access to weaponry increase, climaxing in 1984's arms transfer figures. 
Figure 4.5: Total Number of Arms Transfers to Iran 1977-1992. Source: Stockholm International Peace Research Institute

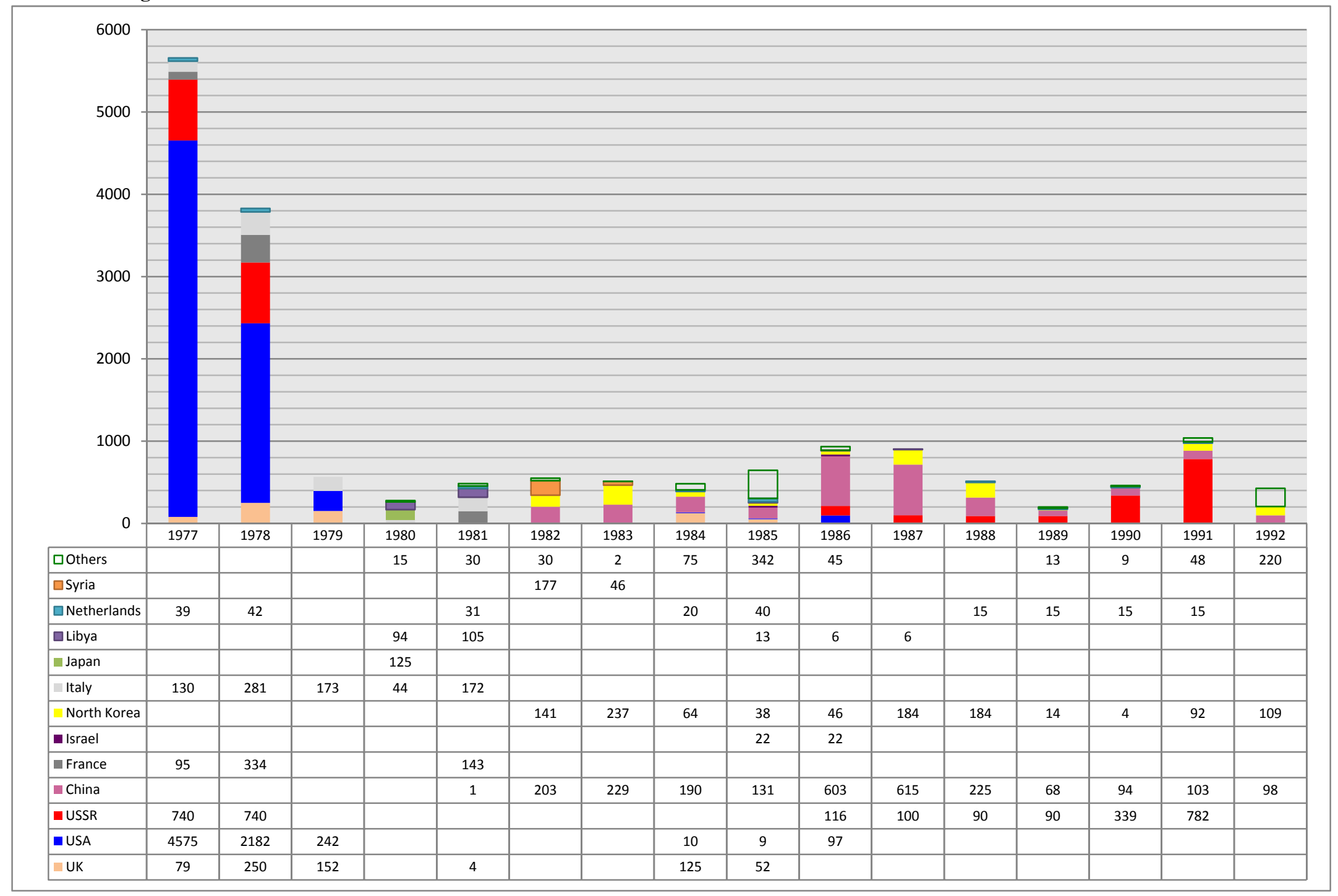




\section{Figure 4.6: Total Number of Arms Transfers to Iraq: 1977-1992. Source: Stockholm International Peace Research Institute}

\begin{tabular}{|c|c|c|c|c|c|c|c|c|c|c|c|c|c|c|c|c|}
\hline \multicolumn{17}{|l|}{5000} \\
\hline \multicolumn{17}{|l|}{4500} \\
\hline \multicolumn{17}{|l|}{4000} \\
\hline \multicolumn{17}{|l|}{3500} \\
\hline \multicolumn{17}{|l|}{3000} \\
\hline \multicolumn{17}{|l|}{2500} \\
\hline \multicolumn{17}{|l|}{2000} \\
\hline \multicolumn{17}{|l|}{1500} \\
\hline \multicolumn{17}{|l|}{1000} \\
\hline \multicolumn{17}{|l|}{500} \\
\hline 0 & 1977 & 1978 & 1979 & 1980 & 1981 & 1982 & 1983 & 1984 & 1985 & 1986 & 1987 & 1988 & 1989 & 1990 & 1991 & 1992 \\
\hline 口Others & & 20 & 3 & 87 & 50 & 49 & 161 & 50 & 8 & 12 & 25 & 36 & 28 & 15 & & \\
\hline Czechoslovakia & 4 & & & & 84 & & & 40 & 40 & & & & & & & \\
\hline South Africa & & & & & & & & & 50 & 50 & 50 & 50 & & & & \\
\hline$\square$ Romania & & & & & & 62 & 62 & 62 & & & & & & & & \\
\hline Egypt & & & & 16 & 33 & 58 & 58 & & 3 & 14 & 59 & 59 & 48 & & & \\
\hline$\square$ Poland & 40 & 20 & 20 & & 148 & 49 & & & & & & & & & & \\
\hline$\square$ Brazil & & & 36 & 97 & 36 & 44 & 46 & 72 & 102 & 59 & 41 & 76 & & & & \\
\hline$\square$ Austria & & & & & 15 & 40 & 40 & 40 & 40 & 25 & & & & & & \\
\hline China & & & & & & 434 & 657 & 958 & 853 & 914 & 991 & 197 & 23 & & & \\
\hline$\square$ Germany (FRG) & & & 12 & 2 & & 26 & 14 & 13 & & & & 25 & 18 & 13 & & \\
\hline$\square$ East Germany (GDR) & & & & & 25 & & & & & & & & & & & \\
\hline France & 99 & 67 & 74 & 274 & 735 & 698 & 750 & 900 & 715 & 155 & 121 & 244 & 71 & 193 & & \\
\hline -USSR & 931 & 1725 & 1098 & 1631 & 1416 & 1661 & 1515 & 2503 & 2243 & 2378 & 2360 & 1103 & 1293 & 555 & & \\
\hline - USA & & & & & & & 27 & & 9 & 9 & 30 & 125 & & & & \\
\hline UK & 24 & & & 6 & & 44 & & & & 7 & 10 & 7 & & & & \\
\hline
\end{tabular}


In subsequent months, these recommendations would be adopted as official policy.

In November of 1983, President Ronal Reagan issued a National Security Directive to implement these policies - firstly to consult US allied regimes of the Persian Gulf, and then other US partners in the wider Middle East:

I have reviewed and approved the Terms of Reference to govern our political and military consultations with our key Allies and the Gulf Arab states. Political consultations should begin immediately followed by military consultations with those Allies and regional states which express a willingness to cooperate with us in planning measures necessary to deter or defend against attacks on or interference with non-belligerent shipping or on critical oil productions and transshipment facilities in the Persian Gulf. In our consultations we should assign the highest priority to access arrangements which would facilitate the rapid deployment of those forces necessary to defend the critical oil facilities and transshipment points against air or sapper attacks. Specific recommendations bearing on US plans and force deployments should be submitted for approval following the consultations. It is present United States policy to undertake whatever measures may be necessary to keep the Strait of Hormuz open to international shipping. Accordingly, US military forces will attempt to deter and, if that fails, to defeat any hostile efforts to close the Strait to international shipping. Because of the real and psychological impact of a curtailment in the flow of oil from the Persian Gulf on the international economic system, we must assure our readiness to deal promptly with actions aimed at disrupting that traffic. ${ }^{401}$

What the US would use to convince its regional allies, which spearheaded the increase of American intervention in the war, was the specter of supply disruption. This apprehension would not only motivate regional producers to come along with US policy, but also persuade other global players, as the memories of 1973 and 1979-80 were still fresh in the minds of many decision-makers.

\footnotetext{
${ }^{401}$ National Security Decision Directive (NSDD 114) from Ronald W. Reagan. 26 November 1983 "U.S. Policy toward the Iran-Iraq War".
} 
As this outreach was beginning, the Reagan administration began upgrading its relations with the Iraqi Baath towards full normalization. To do so, it would send a seasoned Washington insider from the Nixon and Ford administration, which at the time was more in private business as opposed to public life: Donald Rumsfeld. President Reagan designated Rumsfeld as a Special Middle East Envoy, primarily because of his closeness to several figures in the administration. Rumsfeld's mandate was not just to meet with senior Iraqi officials, but more importantly, have a meeting with Iraq's Saddam Hussein. This meeting would be the highest encounter of a direct envoy of President Reagan with the Iraqi leader Saddam Hussein. ${ }^{402}$ Rumsfeld's message to the Iraqis from Washington was meant to unambiguously frame the objectives of Iraq in the war with that of US strategic interests:

President Reagan and the US Government are committed to a sustained effort to help end the war which we see as strategy for the combatants and detrimental to our interests and those of our friends in the area. The US Government recognizes Iraq's current disadvantage in a war of attrition since Iran has access to the Gulf while Iraq does not and would regard any major reversal of Iraq's fortunes as a strategic defeat for the West. The US Government ... will continue efforts to bring Iran to accept or acquiesce in its terms.

When Rumsfeld arrived in Baghdad, the first person that he had a substantive meeting with was Iraq's Foreign Minister, Tariq Aziz. The Foreign Minister consistently referred to the "unnatural imbalance" that was purportedly a major cause for instability in the region, a phenomenon he described as "giving a country more weight than it deserved".

\footnotetext{
${ }^{402}$ United States Interests Section in Iraq Cable from William L. Eagleton, Jr. to the Department of State [et al.] 10 December 1983 "Rumsfeld Visit to Iraq. “

${ }^{403}$ United States Department of State, 14 December 1983. United States Interests Section in Iraq Cable from William L. Eagleton, Jr. to the United States Embassy in Jordan. "Talking Points for Amb. [Ambassador] Rumsfeld's Meeting with Tariq Aziz and Saddam Hussein".
} 
${ }^{404}$ This was a clear reference to Iran, and the economic and military might that the Shah had accrued for the country, mostly in the 1970s. Rumsfeld, representing the administration, agreed with this assessment, and conveyed to Aziz that the war should end "in a way that would not feed Iran's ambitions". ${ }^{405}$ With Rumsfeld's meeting with a deferential Saddam Hussein, and how the Iraqi leader showed "obvious pleasure" with the US approach to Iraq, relations between both countries officially became normalized only a short time afterwards, including the exchanging of ambassadors. ${ }^{406}$ And within days of Rumsfeld's consequential visit, the American policy of financial assistance to Baghdad, with the diplomatic factors that would entail, was now to begin in full effect. ${ }^{407}$

\section{The US broadens its Iraq initiative to its regional allies}

With the structure of the US approach in place, Washington would now need to recruit its regional allies in a concerted and integrated strategy to order to help Iraq in its war effort, assist in the production and transport of its oil, and in contain Iran. Upon leaving Baghdad, Rumsfeld would stop in London to coordinate with Jordan's monarch, visiting London at the time, the upgrading of relations with Iraq. More significantly, the two discussed the building of the Aqaba pipeline, which would not only render more financial assistance to Iraq, but would diversify Persian Gulf oil so that it would become less dependent upon the Strait of Hormuz passageway, and thus less vulnerable to the ongoing

\footnotetext{
${ }^{404}$ United States Embassy in Italy Cable from Maxwell M. Rabb to the Department of State. 19 December 1983 "Rumsfeld's Larger Meeting with Iraqi Deputy PM [Prime Minister] and FM [Foreign Minister] Tariz [Tariq] Aziz, December 19".

${ }^{405}$ Ibid.

${ }^{406}$ United States Embassy in United Kingdom Cable from Charles H. Price II to the Department of State. 21 December 1983 "Rumsfeld Mission: December 20 Meeting with Iraqi President Saddam Hussein".

${ }^{407}$ Department of State, Office of the Assistant Secretary for Near Eastern and South Asian Affairs Action Memorandum from Richard W. Murphy to Lawrence S. Eagleburger. 22 December 1983. "EXIM [ExportImport] Bank Financing for Iraq" [Includes Letter From Lawrence S. Eagleburger to William Draper, Dated December 24, 1983].
} 
war. ${ }^{408}$ Indeed, it was this very subject matter that created the urgency for the Iraqi regime to upgrade relations with the US. ${ }^{409}$

For the US, however, the pipeline was part of an overall strategy in utilizing global oil export dynamics as a weapon against Iran. In early January of 1984, as relations with Iraq were being upgraded to official status, the US National Security Council (NSC) released an early memo concerning US strategy to deal with energy issues in light of the Iran-Iraq war, which by that time was pushing four years. In the memo, the US strategy was to identify countries "likely to have spare capacity" in order to be "approached diplomatically - to ensure increased output if possible". ${ }^{410}$ The plan, already in place by targeting Iran with a web of sanctions, intended to make its economy suffer, dry up its oil revenue, and thus and severally limit its war making ability, was to be expanded with the help of other countries. The countries that were to be approached were the following: Saudi Arabia, the UAE, Kuwait, Nigeria, Venezuela, and other OECD countries. This move was simply a natural extension of the policy advocated for by Lawrence Eagleburger, which on the surface was meant to upgrade Iraqi capacity, but ultimately meant the overt US intervention in OPEC. With the US now openly attempting to change the export policies of OPEC Member States, the internal functionality of Organization would invariably change dramatically.

The most willing participants of the US approach were those that were already sympathetic or supporting Iraq's war effort against Iran: the Persian Gulf Arab

\footnotetext{
${ }^{408}$ Department of State Cable from Kenneth W. Dam to United States Embassy in Jordan. 23 December 1983. "Rumsfeld Mission: Meeting with King Hussein in London".

${ }^{409}$ United States Interests Section in Iraq Cable from William L. Eagleton, Jr. to the Department of State. 10 January 1984. "[Excised] Iraqi Pipeline through Jordan".

${ }^{410}$ National Security Council Memo, 5 January 1984, folder “Iran-Iraq” Box 4, William F. Martin Records. Ronald Reagan Presidential Library.
} 
Monarchies. Being an outlying Member, Nigeria would ultimately stay neutral and not become a significant factor in this proposed export policy. And Venezuela had long looked askance on non-Member States, particularly those from highly industrialized economies, interfering in the affairs of OPEC. Saudi Arabia, Kuwait, and the UAE, in signing onto this strategy merely broadened what they had already been doing in supporting the Iraqi Baath with direct financial assistance.

But as this policy was coming into effect, the nature of the Iran-Iraq war was now dramatically changing. The localized attacks on oil tankers by both countries had now turned into a full-blown strategy that each country was using. This meant that the threat to the wider region was no longer an Iranian closure of the Strait of Hormuz, in possible retaliation to an Iraqi action. It meant that the war was now regionalized to the point that the oil production capacities of all producers, specifically those in the Persian Gulf, were threatened. In March of 1984, the US Interagency Intelligence Assessment confirmed this:

We believe that the warning about possible escalation of the Gulf war contained in SNIE 34/35-2-83 dated October 1983 remain valid. The SNIE predicted a series of intermediate escalatory steps by Iraq in to increase military pressure on Iran, possibly culminating in Iraqi attacks on Iran's Khark Island oil terminal or associated tanker traffic an Iranian retaliation against oil exports form Arab Gulf states. We believe Iraq already has passed through many of the intermediate warning steps outlined in the SNIE. The risk of a serous Iraqi effort against tankers or Khark Island will increase if, as expected, Iran launches its next major offensive, probably within a month. A serious Iraqi effort against Khark is particularly likely if the battle goes badly for Baghdad. On paper Iraq has the capability to shut down Khark Island though direct military attack or attack on tankers calling at Khark. Iraqi willingness to risk heavy losses in such efforts in the question....At a minimum, we believe that Iranians will employ psychological warfare though the use of Iranian inspired and 
supported Shia terrorism directed at Iraq's Gulf supporters as well as US personnel and facilities in the region and beyond.

The Assessment went onto deduce that with the current trend the war was on, two "risk options" would be most likely as it related to Iranian retaliation: a "lower risk" and "more serious steps". ${ }^{412}$ On the former, the US concluded that the Iranians would utilize harassment tactics against vessels, over flights of the offshore facilities of the Arab Monarchies, and possibly attacking Iraqi pipeline exports. However, the higher risk scenario is what concerned the US and its Western partners. This would involve direct attacks by the Iranian armed forces on the neighboring Arab monarchies of the Persian, the main financiers of Iraq's war efforts against Iran, and the primary players in what would turn out to be an oil war against Tehran's oil export revenues. Furthermore, an escalation would logically conclude in the Persian Gulf becoming a no-go zone, due to reasons ranging from mining by the Iranian military to direct naval action.

The culmination of these concerns led to the establishment of a US doctrine towards the Persian Gulf and the wider region for the remainder of the Iran-Iraq war. This was introduced in a white paper that the US State Department put together for the White House, entitled "Iran-Iraq War: Elements of U.S. Diplomatic Strategy and Plans". In the paper, the authors sketched out 9 principle goals that would ultimately become US policy towards the conflict and the region:

1. Maintain active U.S. support for a negotiated settlement that will preserve the sovereignty and territorial integrity of both Iraq and Iran.

2. Take steps to help Iraq avoid defeat by preserving a strategic balance, while maintaining U.S. neutrality.

\footnotetext{
${ }^{411}$ Interagency Intelligence Assessment. 12 March 1984. Iran-Iraq War Folder, Iran Box 36. Executive Secretariat, NSC: Country File, Near East and South Asia [Middle East].

${ }^{412}$ Ibid.
} 
3. Strengthen relations with Iraq, urge it to avoid escalation in the Gulf, stop using chemical weapons.

4. Work through third parties to urge restrain by Iran and a negotiated settlement.

5. Urge third countries to cease arms sales to Iran as a means of confronting Iranian intransigence.

6. Emphasize U.S. intention to defend freedom of navigation in Strait of Hormuz and international waters of the Gulf.

7. Obtain agreement from our allies for joint military operations in a Gulf crisis.

8. Strengthen ties with friendly Gulf States and seek combined military planning and US/Allied deterrent deployments/exercises.

9. Counter Iranian terrorism against U.S. and Gulf states. ${ }^{413}$

This ultimately led the NSC to update their prior strategy and introduce, at the end of May 1984, a memo entitled "Iran-Iraq War National Plan of Action". The NSC memo played out differing scenarios of supply disruption, but ultimately concluded that any policy that would blunt the overwhelming negative effects of the stoppage of Persian Gulf oil flow would need to be a multinational effort:

Bilateral and multi-lateral discussions with selected IEA/OECD partners concerning coordinated stock policies, including special emphasis on: need to increase strategic stocks; need to engage in such coordinated drawdown as appears appropriate in light of circumstances at time of emergency; need to avert overreaction to emergency by governments; and need to coordinate public statements of governments to calm unnecessary panic behavior of marketplace. ${ }^{414}$

The convergence of these varying policy papers would ultimately lead to the US taking on an active military posture to not only defend the free flow of oil, but more importantly, being an active force against Iran in the wider war. As Iran and Iraq, by mid-1980s,

\footnotetext{
${ }^{413}$ United States Department of State. 7 March 1984. "Iran-Iraq War: Elements of U.S. Diplomatic Strategy and Plans". Iran-Iraq War Folder, Iran Box 36. Executive Secretariat, NSC: Country File, Near East and South Asia [Middle East].

${ }^{414}$ Secretary Hodel Presentation: Energy Implications of Current Persian Gulf Situation; NSPG Meeting. 24 May 1984. Iran-Iraq War Folder, Iran Box 36. Executive Secretariat, NSC: Country File, Near East and South Asia [Middle East].
} 
were now in full-blown tanker war, it was only a matter of time where the US and Iran would come to direct conflict. ${ }^{415}$

\section{Interstate Relations}

By the mid-1980s, OPEC's functionality had greatly eroded. The convergence of the downward trend in oil prices, the start of the Iran-Iraq war, the inability of the Organization to implement a ceasefire between two of its founding Members had all but paralyzed OPEC. Moreover, OPEC's move towards price defense - the tendency of Member States to reduce output to tighten supply, in hopes of halting price erosion and increasing prices - only made matters worse for the Organization. Yet, with time, these two dangerous trends - the split within the Organization caused by the Iran-Iraq war and OPEC's fundamental inability to react to changing market conditions - would lead to the virtual disintegration of the Group as the 1980s ended.

\section{The collapse of OPEC functionality}

OPEC's adherence to the exhaustibility theory and its insistence on price defense, as prices were significantly decreasing (See Figure 4.3), was one of the main reasons that in 1981-2, Member States began a series of production cap measures to halt price erosion. 416 The Organization believed that placing a production ceiling on individual Members would halt supply into the market, and thus halt the downward trajectory in price. It was thought that with time, a sufficient tightening of the market would eventually raise prices. This thinking was part of the legacy of the late 1960s, which consistently was reinforced in the 1970s.

\footnotetext{
${ }^{415}$ D. Hiro, The Longest War: The Iran-Iraq Military Conflict (Routledge, 1989), 129-53.

${ }^{416}$ John Gault et al., "How Does Opec Allocate Quotas?," Journal of Energy Finance and Development 4(1999): 137-38.
} 
Yet, the advanced economies' efforts at conservation, while new supplies outside of the OPEC area came into the market only further eroded the Organization's market share. By 1985, roughly the mid-way point of the Iran-Iraq War, OPEC global production share had fallen to its lowest of $29.44 \%$ (See Figure 4.4). And though it would rise again, primarily because of the twin economic and political decisions made by OPEC's now newly dubbed swing producer, Saudi Arabia, the culmination of what had transpired within the global oil market by the mid-1980s was the loss of market share, and more consequentially, the loss of price control by the Organization. For its part, OPEC's diagnosis of the price erosion was completely accurate. On its $25^{\text {th }}$ anniversary press release, the Organization put out one of its most far-reaching and systemic explanations of how OPEC viewed itself in the global economy. In tracing back its history up to the end of 1985, OPEC's perception of the then political economy of the day was very telling in how it would approach this period of falling prices:

the rapidity with which these structural changes in the world energy order took place, as a result not only of market forces but also of the deliberate policy actions of the governments of the consuming countries, created the present over-supply and market weakness. The sharp decline in world demand for oil through policies of accelerated conservation and fuel substitution by consumers, coupled with the dramatic increase in nonOPEC supplies, led to a sharp and rapid decline in OPEC's share of the world's total oil supplies and to the present situation of increasing downward pressures on the oil price structure. Oil producers from outside OPEC have been systematically undercutting OPEC's prices in order to maximize their sales at the expense of OPEC Countries, but, here again, it was OPEC's action of reducing production to defend the oil price structure that had been behind the relative market stability of oil. Without OPEC, the pressure on the market would by now have taken its toll. The price structure would have collapsed and real chaos would have prevailed in the oil market. OPEC has been able to successfully hold the price structure from which other producers are benefiting, but at great sacrifice to its Members and at enormous risks to their development projects. 
Clearly, however, OPEC alone cannot and should not be expected to perpetually provide the insurance policy on the stability of oil prices, while non-OPEC countries sit back and enjoy the benefits of this insurance without paying their share oil the premium. A collapse of the oil price structure would be detrimental to all producers of oil, especially those outside OPEC, whose cost of production is much higher than that of OPEC Countries. Such a collapse would also be detrimental to the consuming countries, insofar as the development of alternative forms of energy is concerned. It could also adversely affect the economies of the industrialized countries and their trade, banking and financial systems. Those who adopt an uncooperative attitude to OPEC in favor of shortterm price cutting will discover, perhaps too late, that the economics of the short term are also the economics of the short-sighted. Since OPEC has proved to be a moderating influence on the international economic scene, it is highly regrettable that some oil-consuming and producing countries outside OPEC have stood doggedly in opposition, refusing to learn from the lessons of history. The loud voices against dialogue with OPEC in some major industrialized countries appear to be relying too heavily on the present soft market conditions, which cannot continue indefinitely. Non-OPEC countries, in maximizing production at the expense of OPEC, are depleting their limited oil reserves so fast that they will soon have to invest huge and exorbitant capital in order to prevent a drastic fall in their production. Conversely, OPEC, which accounts for two-thirds of the

world's oil reserves, is prolonging the life-span of those oil reserves which will eventually bring it back to the fore as the future main supplier of oil in the world. The reality of today's interdependent world must be appreciated and its resources mobilized and utilized for the common good and for a meaningful overall world economic development. We are convinced that what is needed today, after OPEC's quarter-century of useful service to mankind, is the full co-operation of all those involved in the energy industry - OPEC, non-OPEC and consumers alike, in order to maintain the essential oil price stability that would prevent an undue, sharp and disruptive fluctuation in the future world energy situation. It is only to be hoped that, as OPEC celebrates its 25th birthday, it can look forward with confidence to a future of dialogue and co-operation with all partners of the oil and energy trade. ${ }^{417}$

The tone of OPEC's official language had markedly changed from the confidence of the 1970s. But its reasoning had become quite contradictory. The Organization clearly understood who the economic and political forces that have eroded the price structure of

${ }^{417}$ OPEC, Opec Official Resolutions and Press Releases 1960-1990, 231-32. 
crude oil were - and how this process took place. But its premise and prescriptions were not only inaccurate, but would continue to worsen its control over market share and thus control over price, at least for the short term. Of the several misconceptions that the Group had concerning the price erosion, the most harmful to the Organization's interests was the continual and unquestioned acceptance of the exhaustibility theory.

It was the continuance of this belief that would lead the Organization to adopt production quotas for each Individual Member State, in order to collectively reduces OPEC exports. However, the mere adoption of this quota system, was not the main reason for OPEC's inability to affect market conditions. Theoretically, according to classic cartel dynamics, OPEC certainly the requisite power and capacity to tighten global oil supply. Yet, as Raino Malnes, has noted, would require disciplined collection action, which is the main characteristic of a cartel system. ${ }^{418}$ But this type of coordination amongst the differing Member States never in earnest existed within the Group. Collective action was always tactical - whether it was during the early years of negotiations with the Companies, nationalizations precedents, or agreements with OPEC Member Stats National Oil Companies entered into with the International Oil Companies. Collective action, which was synchronized was often agreed, but seldom actually followed.

More so, the political conditions within the Organization - chiefly because the Iran-Iraq war and its indirect consequences - made unanimity of purpose and collective action all but impossible. For the quota system to work, Iran and Iraq, and the Persian Gulf Arab monarchies would have needed to have amicable political ties. The raging

${ }^{418}$ Malnes, "Opec and the Problem of Collective Action," 343-55. 
conflict between Iran and Iraq, the polarization that the war created within the Organization, OPEC's inability to halt price erosion, and its subsequent loss over price control gradually created an altered image of the Organization. What was once a feared Organization by the advanced economies, yet simultaneously respected by many varying developing countries, was now seen as a deteriorating relic of the 1970 s. It was at this time where first scholarly, and then mainstream commentary would notice this change. Mohammed E. Ahrari's OPEC: The Failing Giant was one of the most influential to this shifting narrative of the Organization. Though Ahrari's diagnosis of the maladies that plagued OPEC was strictly in economic terms - too much greed at the end of the 1970 s his work created the template to change the image of the Organization, from a once successful initiative from the developing world to a collapsing institution whose time was

coming to an end. ${ }^{419}$ With Ahrari's template of a failing institution now constructed, though derived in academia, it would, with time, go mainstream - even affecting the perception of many influential OPEC officials.

\section{De-facto Disintegration}

By 1986, it was clear that the quota system then in place had not only failed to bring about a reversal to OPEC's fortunes, but also to halt the steady price erosion that so dramatically was affecting the revenues of each OPEC Member State. The belief in the efficacy of the quota system, rooted in the principle of exhaustibility, drove the Organization's main producers to 'punish the market'. But when this policy failed to do so, for major producers, like Saudi Arabia, the years that they had dedicated to price

${ }^{419}$ Ahrari, Opec: The Failing Giant. 
defense, by helping to institute the quota system, were wasted years due to its inefficacy and how it had indirectly lead to the loss of market share. As OPEC held back its exports from the market, in order to create new price dynamics, others just filled in the gap. For the Saudis, the only way to counter their decline of influence in the market was to turn market dynamics on its head.

In 1986, Saudi Arabia, one of the chief architects of the quota system, effectively abandoned it, and broke away from OPEC's established policy by overproducing. ${ }^{420}$ They did this in consultation with some of their key Arab allies, and backed by the previously explained American plan to contain the fallout from the Iran-Iraq war. This overproduction greatly contributed to the collapse of crude oil prices (See Figure 4.3). Riyadh went from producing in $19853.2 \mathrm{mbpd}$ to expanding production to $4.8 \mathrm{mbpd}$ in 1986, and by 1990, 6.4 mbpd. There was, however, an additional geopolitical reason behind this move. Saudi Arabia's flooding of the market was not only a keen opportunity to punish its competitors outside the OPEC area, and those OPEC Members that were not going along with quota stipulations, but also a way to further erode Iranian oil revenue, as it relates to the Iran-Iraq war. Indeed, the Saudis' decision to abandon their quota to protect Saudi market share, coincided with the major economic problems that Revolutionary Iran was experiencing in their sixth year of war with Iraq. It's important to remember where this rationale had come from, as that the Saudis had previously utilized a similar method against the Shah, which contributed to the Revolution. ${ }^{421}$

\footnotetext{
${ }^{420}$ Dermot Gately, M. A. Adelman, and James M. Griffin, "Lessons from the 1986 Oil Price Collapse," Brookings Papers on Economic Activity 1986, no. 2 (1986): 237-84.

${ }^{421}$ Cooper, "Showdown at Doha: The Secret Oil Deal That Helped Sink the Shah of Iran," 567-91.
} 
By 1988, the economies of both Iran and Iraq were devastated. Iran, being the sanctioned country, found it both increasingly difficult to acquire weapons (that it could not indigenously make) from foreign sources, and more importantly, the revenue to purchase those weapons. The price collapse in 1986, with the additional Saudi output into the market, created unprecedented pressures for the Islamic Republic; so much so that the continuance of the war effort was no longer seen as valuable nor viable. Those in Iran advocating for the acceptance of the UN ceasefire agreement argued that Iran's primary objective had been met: the expulsion of Iraqi forces out of Iranian territory and the return to the status quo ante, which Iran (both under the Shah and the Islamic Republic) was content with. Those advocating for the continuance of the war argued that Iran's objectives were not going to be met until the fall of the Iraqi Baath. Eventually, the former won the argument. For Saddam Hussein's regime, Iran's acceptance of the ceasefire was tantamount to an Iraqi victory, although none of Iraq's initial objectives were met, both territorially and politically. In the end however, the Iran-Iraq war only produced two losers. Not only was the war catastrophic for both countries' civilian infrastructure, ${ }^{422}$ the impact to their oil production capacities, and dramatic decline in their tangible exports severally downgraded the clout of both Iran and Iraq in OPEC. This would be significant throughout the 1990s, as Saudi leadership would dominate a weakened institution.

As the decade closed, OPEC officials were hopeful that with the end of the IranIraq war, the Organization's future would return back to the what had transpired in the 1970s, when OPEC was a unified force in the global economy that actually benefited its

\footnotetext{
${ }^{422}$ Hooshang Amirahmadi, "Economic Reconstruction of Iran: Costing the War Damage," Third World Quarterly 12, no. 1 (1990): 27-47.
} 
Members. In a 1988 Press release, the damage that the market dynamics of the 1980s, along with the hostilities between Iran-Iraq caused the Organization, was clearly felt and now openly expressed:

Despite OPEC's many positive achievements, however, the current decade has brought with it some very serious problems for the Organization, making it perhaps the most difficult period in its history. These difficulties, which center around the ways and means of stabilizing the volatile oil market at prices that are fair to both producers, within and outside OPEC, and consumers, are still very much present today. As so often in the past, both depressing and heartening developments for the Organization have been witnessed in 1988. The year began inauspiciously, with the impact of an oil glut which had become apparent in the second half of 1987 being carried over into the new year. Excessive supplies of oil, as well as accelerated stock-building by consumers, combined to threaten the price stability which OPEC had managed to restore to the market with its return to a fixed price regime at the beginning of 1987. As a result, prices, which had been climbing steadily towards - and on occasions even exceeding the Organization's reference price oU18 per barrel, began to falter and fall back....An historic meeting between OPEC and seven non-OPEC oilproducing countries in April 1988 represented a milestone in OPEC/non$O P E C$ relations, and helped lay the foundation for future dialogue and cooperation between a large number of oil producers, in an atmosphere of mutual trust. All the countries present at this gathering agreed on the importance of the meeting, and that a stable oil market was the responsibility of all parties engaged in the industry, with the burden consequently - to be shared by all. It was also agreed that such an initial meeting should be followed by continued contact to review the agreements that were arrived at and to plan future avenues of cooperation.... Undoubtedly, one of the most important developments of the year, not only for OPEC but also for the world as a whole, was the cessation of hostilities in the Gulf. ${ }^{423}$

OPEC's Secretary General Subroto, on the eve of the 1990s, echoed this sentiment. By describing the 1980 s as the decade "characterized by confrontation", the Secretary expressed that the Organization looked "forward optimistically" to the 1990s as a

\footnotetext{
${ }^{423}$ OPEC, Opec Official Resolutions and Press Releases 1960-1990, 279.
} 
"decade of cooperation". ${ }^{424}$ The hope for the Organization was that though Iran and Iraq, and the latter's supporters within the Organization, had deep mistrust and antagonism towards each other, the incentives towards cooperation, at least for the time being, would subsume the animosity generated in the 1980s. Indeed, it was sheer economic enticements that brought together these disparate countries in the first place. And it was thought that the same desire for economic gain, specifically in light of the decade of economic loss that the Organization had gone through, would motivate Members to once again collaborate.

As OPEC entered the 1990s, the most pressing issue for interstate relations was to repair and overhaul the broken quota system. So ineffective was this system that the Organization publicly declared it a failure, but more importantly, made it a benchmark in how OPEC would move forward. As each Member was formulating their own policy based on parochial national interest and an ad-hoc, tactical reading of short-term market trends, unity of purpose within the Group and organizational consensus had long broken down. So much so, that OPEC's institutional leadership, in a press release, openly stated that "only strict adherence to quotas, actually verified by the market, will demonstrate each country's willingness to restore the price basket". ${ }^{425}$ Thus, for the leadership, getting Members to both agree, and more importantly, implement a new quota system was the key priority for OPEC in the next decade.

But beneath this objective laid the unintended consequences of the Iran-Iraq war, of which the Organization was largely ignorant about. For Iraq, the deep fiscal constraints

\footnotetext{
${ }^{424}$ Organization of the Petroleum Exporting Countries, Viewpoint: Opec Series (Vienna, Austria Organization of the Petroleum Exporting Countries., 1989), i.

${ }^{425}$ OPEC, Opec Official Resolutions and Press Releases 1990-1997 (The Secretariat, Organization of the Petroleum Exporting Countries, 1998), 1-2.
} 
caused by the damage to large swaths of its oil infrastructure, the debts accrued because of the war, and with little non-hydrocarbon industries to generate revenue, eventually caused desperation within the Baathist regime. The Saudi overproduction indirectly hurt Baghdad (a key Saudi ally during the 1980s), just as much as it was directed to inflict punishment on Tehran. Subsequently, the years that the Persian Gulf Arab monarchies had lent Baghdad financial loans were now coming due. And with crude oil prices in the doldrums, Iraq's capacity to pay back the war debt was increasingly limited. For Baghdad, the argument they made to their debtors, particularly the Persian Gulf Arabs, was that Iraq had been the front line against Revolutionary Political Islam, which was rooted in Iran, and which threatened the political viabilities of the varying governmental systems in the Persian Gulf and beyond. ${ }^{426}$ Saddam's argument was that Iraq's war against Iran was on behalf of all Arabs. For its part, whether they bought this argument or not, the Saudis wrote off virtually all of the war debt that Iraq had accrued. Kuwait, however, was not so generous.

As OPEC was attempting to institute a new quota system, the old grievances that Iraq and Kuwait had towards each other gradually resurfaced. These were as old as Iraq's claim to the entirety of Kuwait, territorial disputes about oil fields in the Persian Gulf and on bordering areas, how shared oil fields would be exploited, and what had triggered the renewal of these grievances, the massive debt that Iraq owed to Kuwait. Though diplomatic means were tried, particularly by the Kuwaitis, in order to stave off conflict, ultimately, war became unavoidable.

Iraq's August 1990 invasion of Kuwait came at a complete surprise to OPEC,

\footnotetext{
${ }^{426}$ M. Khadduri and E. Ghareeb, War in the Gulf, 1990-91: The Iraq-Kuwait Conflict and Its Implications (Oxford University Press, 2001), 77-95.
} 
much of the international community, the superpowers, and many of the regional players in the Middle East. Since the invasion, several attempts have undertaken to explain the rationality of why the war happened. ${ }^{427}$ Greed, miscalculations, and fear on the part of the Iraqi Baathist leadership and provocation and an inability to be flexible with Iraq's war debt by the Kuwaitis have all been offered as contributing factors. Yet, it was the peculiar mix of miscalculations on the part of the Iraqi Baath that eventually made war unstoppable. These miscalculations centered on Iraq's past behavior with attacking a neighboring country and also its perception of the reaction of the superpowers and the larger international community. When Iraq invaded Iran, not only did the Baathist regime get little to no international condemnation, but indirectly, it was rewarded with financial and military assistance, and diplomatic normalization with the West - all the while it expanded its relations with the USSR. Thus, when Saddam interpreted the comments of US ambassador to Iraq, April Glaspie, as somehow Washington being indifferent to his invasion of Kuwait, ${ }^{428}$ his misreading was arguably rooted in past experience.

By the end of the Iran-Iraq war, Saddam's relationship with the US was heading into troubled waters, by reasons of renewed mistrust and misperception. The Iran Contra Affair, in which the Reagan administration used illegal arms transfers to Iran to pay for paramilitary operations in Central America, ${ }^{429}$ changed the image of the Reagan administration to the Iraqis. This mistrust even elicited a strong reaction from senior US officials, most importantly President Reagan's letter of reassurance to Saddam Hussein.

\footnotetext{
${ }^{427}$ See: A. Baram and B. Rubin, Iraq's Road to War (Palgrave Macmillan, 1996).

${ }^{428}$ See: John J. Mearsheimer and Stephen M. Walt, "An Unnecessary War," Foreign Policy, no. 134 (2003); R.A. Abrams, Reinterpreting Saddam Hussein's Meeting with April Glaspie: Toward a Comic Corrective of an American Victimage Ritual (Indiana University, 1996).

${ }^{429}$ L.E. Walsh, Firewall: The Iran-Contra Conspiracy and Cover-Up (Norton, 1998).
} 
In his 1986 letter, President Reagan sought to restore confidence in Hussein that US policy was still to "restrain shipment of arms to Iran". ${ }^{430}$ However, the Iraqi Baath figured that it could always balance its relations with the US by once again leaning heavily on the USSR.

Yet these miscalculations were catastrophic for the Iraqi leadership. Though Iran was viewed by the West, on the eve of the Iraqi invasion of Iran, as a globalized threat, and hence easily securitized, Kuwait had no such threat factor associated to it. More importantly, the Iraqi traditional reliance on the USSR, by 1990, was an obsolete geopolitical paradigm, as the Soviet Union, unbeknownst to many, was in the process of imploding. And thus, reliance on a failing superpower to keep it from international condemnation, just as relations with the US were to fall apart, dramatically put the Iraqi regime in an place of international isolation that they had not experienced before.

The invasion of Kuwait, the destruction of Kuwait's oil infrastructure by the Iraqis, and the subsequent destruction of key sectors of Iraq's civilian oil infrastructure by the US-led coalition intended to expel Iraq out of Kuwait, crystallized the perception of OPEC as a failing, third world relic. Markets, governments, and other international actors now questioned OPEC's self-professed claim to being a stabilizing force in the global economy - a mantra that the Organization had adopted years prior and long aspired to. If the Organization could not stop its founding Members from going to war with each other, how could it possibly diagnosis and prescribe macroeconomic energy solutions.

With Operation Desert Storm, the Iraqi-American relationship officially ended. The US, no longer constrained by a powerful Soviet Union, which was at that time

\footnotetext{
${ }^{430}$ National Security Council Memo, 1 November 1986, folder “Iraq (1987-1988)” Box 91849, William Burns Records. Ronald Reagan Presidential Library.
} 
slowly disintegrating, took this opportunity to force its own preferences upon the Organization. The initiation of this process was the implementation of the dual containment policy on two of OPEC's founding Members: Iran and Iraq. ${ }^{431}$ What this meant was that for the first time since the creation of the Organization, OPEC's collective output policy would now be openly dictated by non-Members. And though granted, the US was in the unipolar moment of its geopolitical power, the behavior exhibited by Washington towards the Organization had traditionally been measured, indirect, and always behind the scenes. US intervention openly targeting the oil production capacities of Iran and Iraq was new. And the resulting internal power dynamics within the Organization as result of this targeting of Iran and Iraq's exports created a new set of circumstances within the Organization, giving greater influence within OPEC to Saudi Arabia and its likeminded allies.

Furthermore, the beginnings of the draconian sanctions regime on Iraq would commence within months after the US-led expulsion of Iraq from Kuwait. The economic warfare that Iraq would undergo after Desert Storm would take the country back economically, socially, environmentally, and politically - at least a generation if not more. And as this new process would unfold, OPEC as collective unit no longer had the ability to respond or formulate policy in any effective way. And with the beginning of 1993, OPEC once again underwent a significant price collapse, of which in its current weakened state, was completely helpless to avoid or properly respond to. And so OPEC's civil wars, and the failure of the Organization to prevent the fracturing of unity had

\footnotetext{
${ }^{431}$ See: S.M. Wright, The United States and Persian Gulf Security: The Foundations of the War on Terror (Ithaca Press, 2007), 93-162; A.H. Cordesman and A. Hashim, Iran: Dilemmas of Dual Containment (Westview Press, 1997).
} 
mortgaged its future, for the first time, to the outside powers that so long had tried to control the direction of Organization. 


\section{CHAPTER V • THE REBALANCING PHASE, THE GRADUAL}

RECENTRALIZATION OF OPEC, 1993-2008

At the end of the Iran-Iraq war, OPEC's leadership desperately hoped for reconciliation among its Member States. But as the Organization's hopes were dashed by the Iraqi invasion of Kuwait and the ensuing Desert Storm war to extricate the Baathists out of Kuwait, OPEC, for the first time since its creation, lost control over its functionality and future. Subsequently, the Organization entered a phase of its history where its very existence became increasingly in doubt, both by its critics and its supporters - even its former officials. ${ }^{432}$

This era of OPEC's institutional life, more than previous eras, was significantly impacted by the evolution of US power and its dominance in the international system. Regarding Market Forces, while many OPEC officials had hoped that the price erosion of the 1980 s would end with the beginning of the 1990 s, the continued efficacy of advanced economies post-1973 energy strategy (i.e. more efficient transportation, new sources of oil supplies, and alternative sources energy.) continued to suppress and even further erode the overall price of oil. This was compounded by the implosion of the USSR and its disintegration into 15 republics, which would, in time, open up new energy-rich states, such as Kazakhstan, Azerbaijan, and Turkmenistan to Western investment.

Though OPEC would gradually regain a significant portion of its market share that it lost in the 1980s, the aforementioned trends and the inability to collectively act on tactical and strategic matters would keep price control out of the Organization's grasp.

${ }^{432}$ See: F.J. Al-Chalabi, Opec at the Crossroads (Pergamon Press, 1989). 
This, by default, created a new free-market oriented pricing system, unlike the prior systems that either the major oil companies, via cartel behavior, or OPEC, dominated.

In the Rebalancing era, the role of the United States vis-à-vis how OPEC behaved in the international system would be the most consequential since the creation of the Organization. Ever since OPEC's inception, American policy and behavior towards the Organization had always been reactive. Even at the end of the 1970s, when US and allied nations successfully began the implementation of their alternative energy and diversifications strategies, their motivation was one of defensiveness. Yet in this Rebalancing era, specifically for the rest of the 1990s, the US would go on the offensive, seeking to reshape the entire dynamics of oil towards its favor while directly weakening any centralization of oil export planning. But the ability of the US to consequentially weaken the Organization had its limits. At the turn of the century, macro consumption changes would ultimately diminish the ability of OPEC's critics to keep prices low and prevent a new era of cooperation among Members - even though this cooperation was limited, measured, and tactical.

Coincidentally, the US action within the Middle East, coupled with the major changes in Venezuelan politics at the end of the 1990s, would set the stage for the internal dynamics of OPEC's Member States to have profound effects on OPEC's resurgence in the first decade of the 2000s. Indeed, the internal changes of leadership in Caracas and Baghdad - the former by democratic populism while the latter was imposed via invasion - would become the most profound for the Organization in this period. The long drawn-out conflict between the US and Baathist Iraq, born out of the Desert Storm conflict and resulting in the crushing sanctions regime placed on Iraq (with the overt help 
of US allied OPEC Members of the Persian Gulf), would finally come to a head in the immediate post 9/11 geostrategic environment. With the invasion of Iraq and the toppling of the Baathist system, the ramification of Saddam's fall would affect every Middle Eastern state, of which the most consequential would be the Persian Gulf Arab Monarchies and Iran. More so, the ability of the Islamic Republic of Iran to rebuild from the Iran-Iraq war and normalize its diplomatic relations during this period, with the significant exception of its relations with the US, made it suited to take advantage, albeit on a limited basis, of much of the macro changes in internal OPEC dynamics, the wider Middle East, and the global oil industry. And this trend was also extended in its ability to project unconventional power in US occupied Iraq, which helped it to foster, for the first time, a friendly government in Baghdad that would eventually coordinate security and economic policy, indirectly affecting oil related matters.

The changes at the domestic level of OPEC States would eventually affect the interstate relations of the Organization. In the minds of the Persian Gulf monarchies, the change of domestic political control in Baghdad, though they traditionally mistrusted the Baathists, would fundamentally transform Iraq from a barrier against the Iranians to an open collaborator with them. For Iran, an enemy became a potential partner. Furthermore, the rise of Hugo Chavez under a populist-driven, socialist movement in Venezuela significantly added a newfound relevance to the Organization in the beginning of the $21^{\text {st }}$ century. In Chavez and his Bolivarian government, the Organization's interests would once again compete and often times trump the narrow interests of certain Member States.

But as these internal and interstate alterations were happening, rising oil consumption patterns in the global economy, particularly as it relates to Chinese and 
Indian energy demands, would eventually intersect with a brewing storm of mass spending in the public and private sectors of many advanced economies. Chinese and Indian growth, starting in the beginning of the $21^{\text {st }}$ century, would gradually but continuously, push oil prices far above what they had been in over a generation. As the 1990s ended, the US and other allies in the advanced economies witnessed the end of the efficacy of their diversification strategies.

It was in this period where OPEC solidified the regaining of much of its lost market share from the 1980s and 1990s. But as consumption would steadily increase, greatly assisted by rising spending in the advanced economies, rising oil prices gradually turned into a new threat - a replay of the 1970s. And as new worries about supply, and the 'peak oil' narrative developed, prices would start to affect economic growth. This was highlighted by the direct and indirect affects that rising oil prices had in the summer of 2008 , only weeks before the triggering of the financial crisis of 2008-present. With the beginning of this crisis, the Rebalancing phase of OPEC's institutional life would end, bringing the Organization to the present fragile and varying conditions of the global economy.

\section{Market Forces}

As the 1990s began, the geopolitical and geo-economic trajectory of international relations was almost impossible to forecast. While the 1990-1991 Gulf War had created short-term consensus among rivaling countries in the Middle East region and beyond, primarily because of the audacious nature of Iraq's plan to annex Kuwait, the future of international cooperation still was a mystery. US decision makers understood that while the 1980s had been a devastating decade for OPEC, it was also trying time for the USSR. 
Being a major oil exporter, the Soviet Union had dramatically suffered because of plummeting prices, some of which was actually expected by Western Sovietologists. ${ }^{433}$ Moreover, by the mid-1980s, Soviet inspired and aligned Communist political systems were dramatically lagging behind their free-market counterparts in such critical issues as domestic governance efficacy, economic growth, and political stability.

But the Soviet Union's invasion and occupation of Afghanistan, to support and uphold a friendly Communist regime, ${ }^{434}$ had drained the country of vital resources at a time where its oil revenues had dwindled. For the Soviets, Afghanistan was akin to the US experience in Vietnam several years prior. Yet, with the pullback from Afghanistan in the Gorbachov era, the war effort, compounded by the mass decrease in oil revenue and the structural problems in the Soviet economy, had created terminal issues for the Soviet leadership.

The US understood that there were deep changes in the Soviet leadership and that structural problems in Soviet governance were finally coming to the surface. This was evident throughout the end of the 1980s as the USSR experienced serious governance problems as smaller provinces on the periphery would agitate for independence, ${ }^{435}$ and in the case of Armenia and Azerbaijan, engage in open warfare with each other. ${ }^{436}$ However, the extent of the problems to the outside world, even though the Soviets were attempting at controlled political liberalization and economic reforms, was not known.

\footnotetext{
${ }^{433}$ Philip Hanson, "Economic Constraints on Soviet Policies in the 1980s," International Affairs (Royal Institute of International Affairs 1944-) 57, no. 1 (1980): 21-42.

${ }^{434}$ H. Kakar, Afghanistan: The Soviet Invasion and the Afghan Response, 1979-1982 (University of California Press, 1997), 32-50.

${ }^{435}$ Gregory Gleason, "The Federal Formula and the Collapse of the Ussr," Publius 22, no. 3 (1992).

${ }^{436}$ Niall M. Fraser et al., "A Conflict Analysis of the Armenian-Azerbaijani Dispute," The Journal of Conflict Resolution 34, no. 4 (1990): 652-77.
} 
Thus, the actual, physical disintegration of the Soviet Union and the end to its viability in the international system was not expected. And when it did end, under the leadership of President George H.W. Bush, the disintegration process was neither celebrated nor actively encouraged, but as Christopher Maynard has shown, was handled with deep caution and prudence, primarily because of the fear surrounding the Soviet nuclear arsenal. ${ }^{437}$

While the Soviet implosion would have consequential impact on the international system, primarily how the end of the Cold War would affect international cooperation and security, because it was not widely expected, there was little planning for its ramifications it in the wider global economy. Moreover, the fallout on global oil industry itself was not well understood. In the early months of the 1990s, just before the Soviet demise, OPEC officials were already planning their strategy to bounce back from the disastrous 1980s. In a speech given in Tripoli in February of 1991, OPEC's influential Secretary General Subroto, predicted a somewhat return to normalcy for the Organization:

In 1988, growth in world oil demand averaged 3.3 per cent. In 1989, it fell to 2.2 per cent, and in 1990 it slowed further to around 1.1 per cent. This year, as a result of the combined weight of a number of factors, some of which have been gathering strength recently...it is likely to fall yet again. However, we in OPEC believe that in the longer term, the downward trend will be reversed. According to our OPEC energy in-house model and to other predictions, average 1990 world oil demand - excluding the former CPEs - stands at around 51.76 million barrels a day. By 1995, it will be around 54.83 million barrels a day, and in the year 2000, about 57.67 million barrels a day. On the supply side, OPEC calculates that nonOPEC oil supplies, which averaged 27.34 million barrels a day in 1990, will decline to 27.07 million barrels a day in 1995, and to 26.19 million barrels a day in the year 2000. This would put the call on OPEC oil,

\footnotetext{
${ }^{437}$ C. Maynard, Out of the Shadow: George H. W. Bush and the End of the Cold War (Texas A\&M University Press, 2008).
} 
including natural gas liquids, at 24.42 million barrels a day at the end of 1990, at 27.76 million barrels a day in 1995, and at 31.48 million barrels a day in the year 2000. This would mean that by the end of the century, ${ }_{438}$ PEC would be supplying more than half the total world demand for oil.

Subroto's message, on an elemental level, was not just to provide his audience with a panoramic view of the global supply and demand dynamics, but to squarely address the deep concerns with OPEC's collapsing market share. Of the many losses and setbacks that the Organization experienced in the decade of the 1980s, it was the erosion of its influence in the global oil industry that was the most worrying to OPEC Member States. And this loss of influence was directly related to OPEC supply diminishing in the global oil market, to be replaced by new sources of supply and better upstream technologies. But as Figure 5.1 shows, by the beginning of the 1990s, the Organization, primarily fueled by the Saudi decision to break away from the quota system, had already regained much of its market share.

By the early 1990s, the influx of non-OPEC oil in the global supply, as Figure 5.3 shows, was simply not enough to keep OPEC from recapturing substantial lost market share. And though alternatives sources of energy were making strides for the advanced economies' diversification efforts, their impact was far more limited than was hoped for. Thus, Secretary General Subroto's optimism was not totally unwarranted. However, with the Soviet implosion, disintegration, and the emergence of the newly independent Central Asian countries, the global oil dynamics - chiefly as it relates to fears of supply disruption - radically changed. With no Soviet threat that would menace Middle East

\footnotetext{
${ }^{438}$ Organization of the Petroleum Exporting Countries, Viewpoint 1991: An Opec Series, ed. Barry Morgan (Vienna, Austria Organization of the Petroleum Exporting Countries., 1992), 27.
} 
supplies, the 'fear premium' on global supply would significantly decrease. As pricing of crude oil was, by the 1990s, a far more free-market enterprise, lacking a cartel like control by the oil companies or the incremental price hikes that OPEC was able to implement (again because of its market share domination), investors and speculators were able to apply a more predictable model for future supply. And, as Figure 5.4 shows, for the rest of the 1990s, global consumption increased only incrementally. Hence with predictable, but growing supply, and predictable but measured demand, without the fear premium that the Soviet presence and the Cold War imposed on the global economy, as Figure 5.2 details, crude oil prices continued to stagnate. Indeed, crude oil prices in 1993 relapsed to 1986 figures.

\section{Prolonged ineffectiveness: OPEC in the dark ages, 1993-2000}

As OPEC witnessed the slow regaining of its market share, the next phase of its recovery plan, and the most important for the short-term economic wellbeing of its Member States was the issue of price. Previously, the supply conditions in the market would accommodate the Organization introducing measured price increases for their oil. But because the Fragmentation phase had lasted so long, and complimented by the rise of alternatives supplies and sources of energy, the notion of centralized price control eroded.

The hope was that a recentralization of the Organization would allow it to exercise the innate influential capacity that it had with such large market share. But when that did not happen, gradually Member States began to realize that even with the regaining of large parts of their market share that had been previously lost, the dynamics surrounding price control had radically changed. In essence, OPEC's situation had turned back to the 1960s, but this time, with no identifiable set of actors to blame. 
Figure 5.1: OPEC Crude Oil Production by country, as Member States joined the Organization. $1992-2010$ (1000 b/d) Source: OPEC Statistical Data. http://www.opec.org/opec_web/en/data graphs/330.htm

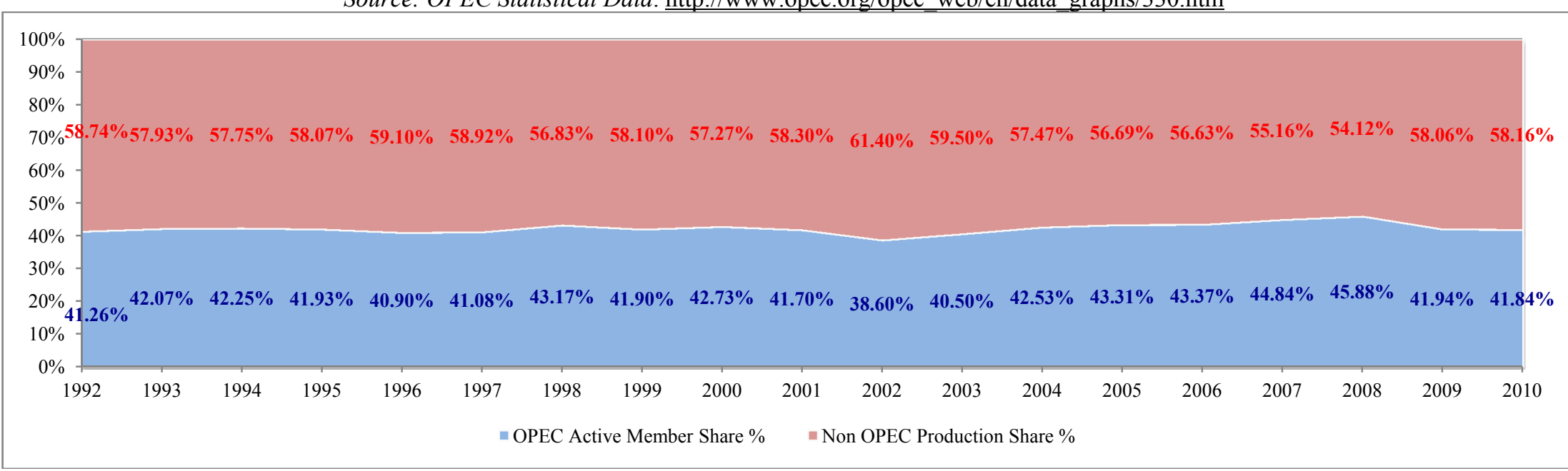

Figure 5.2: Crude Oil Prices: 1990-2011 (US dollars per barrel) Source: BP Statistical Review

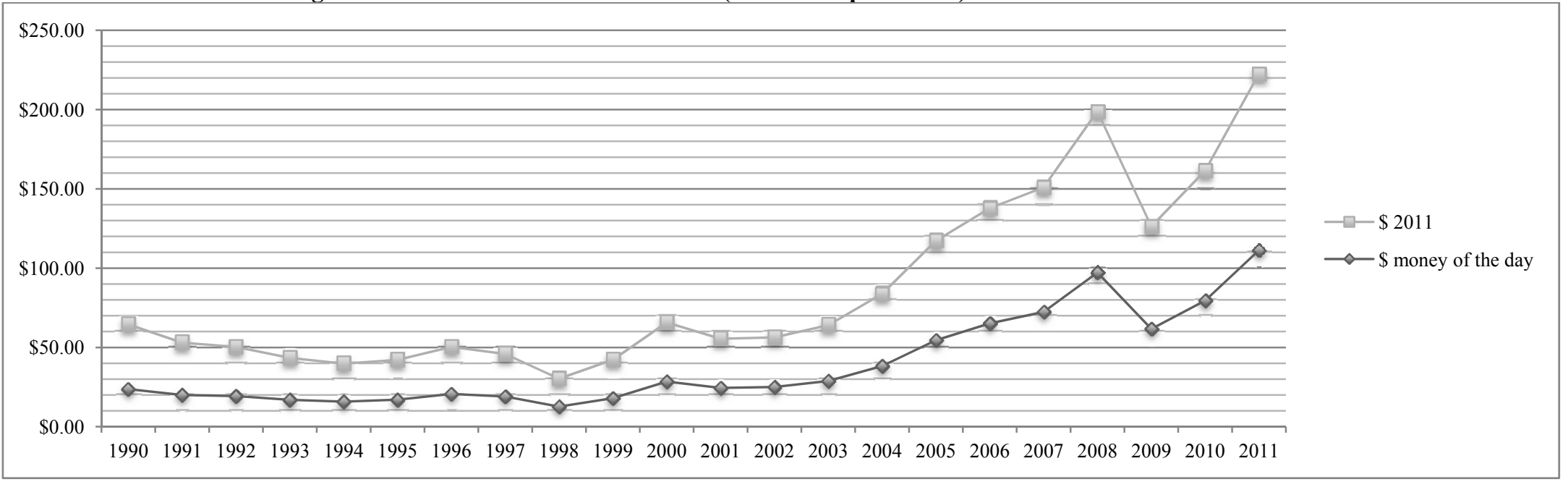


Figure 5.3: OPEC Crude Oil Production by country, as Member States joined the Organization. 1990-2010 (1000 b/d) Source: OPEC Statistical Data. http://www.opec.org/opec_web/en/data_graphs/330.htm

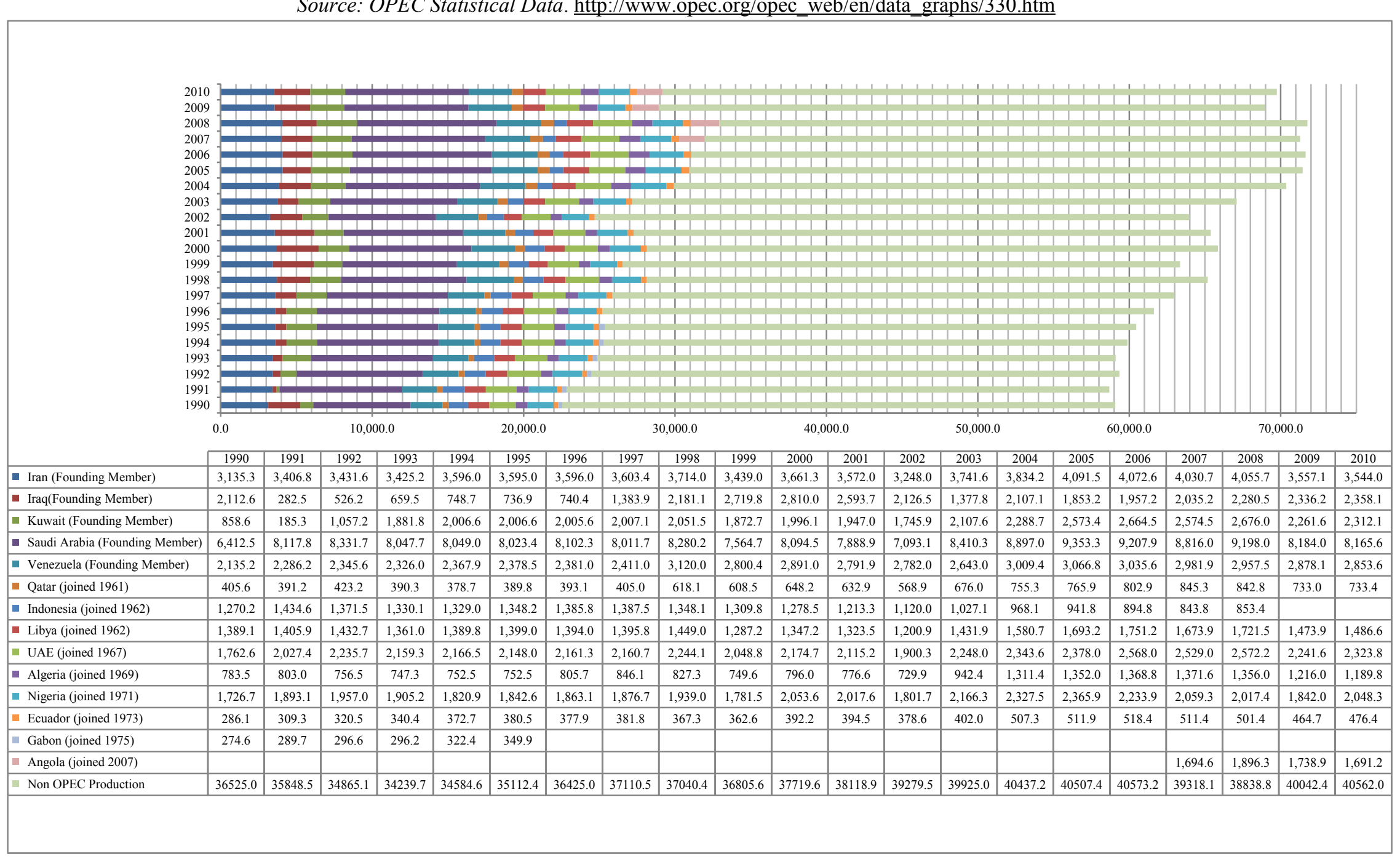


Figure 5.4: Global Oil Consumption by Regions: 1990-2010 (Thousand barrels daily) Source: BP Statistical Review of World Energy June 2013

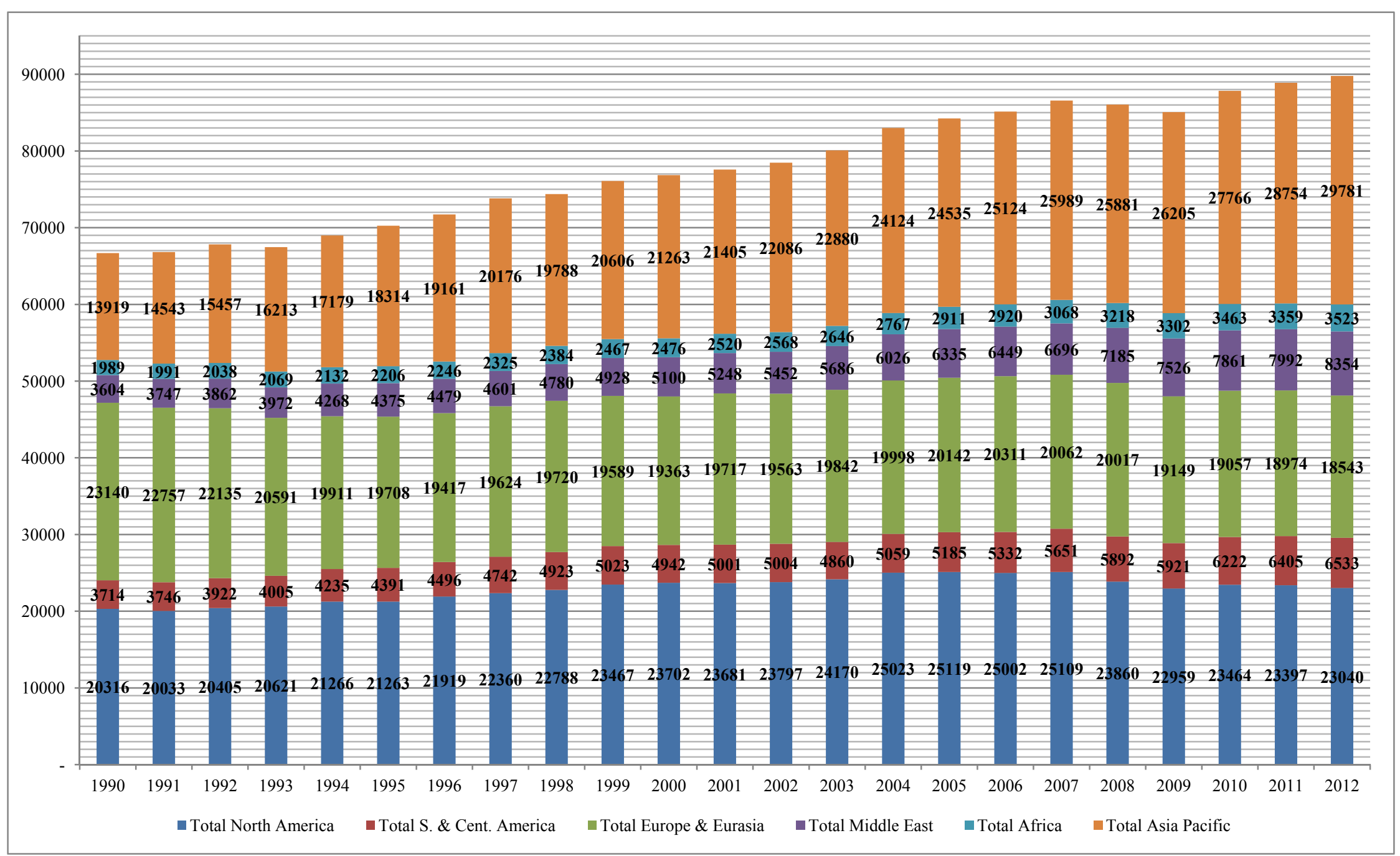


In February 1994, in a speech to the Society of Petroleum Engineers in Vienna, OPEC's Secretary General Subroto squarely addressed the harsh reality of crude oil prices and the inability of the Organization to fundamentally change or address this problem:

...we cannot ignore the fact that oil prices are so low. In fact they have recently been at their lowest for two decades, adjusted for inflation and exchange rates. This is partly the result of recessionary economics prevalent around the world and partly the result of over-supply due to the increasing production coming from non-OPEC sources. OPEC Members have been exercising self-restraint and have maintained their current level of production for more than six months, but we have also been faced with pessimists in the market who take the view that our constant level of supplies represents a failure to make substantial reductions. I would simply state that OPEC Members are not the only producers and before worldwide oil production can be reduced in the short-term it must stop expanding. The implications of low prices for the oil industry are clear: many fields are becoming marginal, profit margins are being squeezed at all levels and oil companies are renegotiating their terms and conditions, reconsidering development activities and, in many cases, downsizing their operations...These pressures are unlikely to diminish in future, even though prices must eventually rise once more. Once strict controls have been imposed they are not easily, if ever, eliminated. The oil industry is in a new rational, economic phase and we must all pull our weight or be left behind. ${ }^{439}$

From the optimism of three years prior, Secretary Subroto and the Organization's leadership had now a dramatically different reading of the market conditions that OPEC was operating under. They understood that without an active capability to affect and influence pricing dynamics, Member States would only suffer from a decrease in revenue, increase in budgetary deficits, and experience the political ramifications domestically. More worrying for the Organization, was that OPEC had no real viable plan to recapture price control or even introduce some temporary fixes. An updated quota system was still

439 , Viewpoint 1992-1994: A Selection of Speeches

by Dr Subroto, Secretary General of Opec, ed. Eduardo Luraschi Graham Patterson, An Opec Series (Vienna, Austria Organization of the Petroleum Exporting Countries., 1994), 307-09. 
in place, which was basically a legacy of OPEC price defense policy of the 1980s - a policy which was largely a failure.

Yet, even if OPEC had the institutional strength to coherently act collectively, had the Organization attempted to significantly cut output, it would have faced significant other hurdles. Firstly, just as Arab producing countries found out in the wake of their failed oil embargo in 1967 against the supporters of Israel, when supply is increasing, faced with steady or stagnant demand, production cuts will have negligible effects on the market. Secondly, OPEC would surely have experienced significant backlash from many actors within the international community, further staining its reputation, and possibly facing a new round of blowback with the same intensity that followed after the 1970's price hikes. In the new post-bipolar world order, lower oil prices were part and parcel of what many considered the 'peace dividend' that was purportedly one of the benefits to the end of the Cold War. With these hurdles, OPEC's default policy was to implement a measured, limited output into the global supply.

However, by 1995, this policy was deemed to be failing, as it did not help with price stagnation but also threatened the very same market share that OPEC had recently regained. In its $99^{\text {th }}$ Meeting, Venezuela's Minister of Energy \& Mines, Dr. Erwin Jose Arrieta, who was acting President of the OPEC conference that year, laid out the difficulties of OPEC's impasse:

The continued efforts of OPEC intending to stabilize the oil market through self-imposed restrictions on output, have been unduly abused. Our agreements are permitting other oil-producing countries to steadily erode our market share - to such an extent that even the absolute demand for OPEC's oil is under threat. While OPEC is producing below capacity, other producers are stretching their supply to the limit. As we all know, this does not bode well for the general welfare of the market. There are also dangers in the longer term. Since the beginning of this decade, we 
have repeatedly stated the need for an adequate level of investment in the production capacity of OPEC. This is the only way to ensure sufficient supply for the turn of the century and beyond, to meet future increases in demand.... Unchecked increases in non-OPEC supply are depriving OPEC countries of vital funds required for investment in new capacity. This can only result in a future supply crisis, characterized by an escalation in prices and widespread instability. This malaise could then continue for a long time... It is in our best interests that the market performs at all times in a stable, predictable manner, with equitable returns for all its participants. A healthy oil market is essential to OPEC, since oil revenue accounts for the bulk of our Member Countries' national wealth. Furthermore, security of supply has a broader connotation than just dealing with unexpected sharp crises, as and when they may arise. I have in mind the situation that was created at the end of the 1980s, when the dissolution of the Soviet Union brought about the withdrawal of a substantial quantity of crude from the world's supply in a relatively short time; net exports fell by one and a quarter million barrels a day in just two years. Then OPEC had the capacity and the flexibility to make up the shortfall and thus minimize the impact on oil prices. But next time, if we are now deprived of the income needed to support it, this capacity and this flexibility is not going to exist. ${ }^{440}$

Simply put, Arrieta's canvassing of OPEC's predicament is an acknowledgment that the Organization was not able to stop the price erosion, while also admitting that the price collapse was weakening production capacity. And with production capacity stunted, domestic revenue intake would also suffer, thus causing both economic and political difficulties at home for Member States.

As the 1990s drew to a close, OPEC's attention was mainly focused on continual revisions to its quota system. This was particularly crucial for Iraq in light of the oil-forfood humanitarian plans that the United Nations had agreed with Saddam Hussein's sanctioned government. ${ }^{441}$ But as OPEC's inability to act collectively, even on tactical related matters, was clearly visible to both its supporters and critics, it was increasingly

\footnotetext{
${ }^{440}$ OPEC, Opec Official Resolutions and Press Releases 1990-1997, 64-65.

${ }^{441}$ H.C. Sponeck, A Different Kind of War: The Un Sanctions Regime in Iraq (Berghahn Books, 2006), $223-61$.
} 
becoming unable to justify to those very officials who had long championed the cause of OPEC from within the Organization.

One of the most significant critiques came from Fadhil Chalabi, OPEC's deputy Secretary General from 1978-88 and acting Secretary General from 1983 to 1988. Chalabi's article, "OPEC: An Obituary" was a major turning point in how others saw the Organization. ${ }^{442}$ Chalabi's proclamation was no mere uninformed opinion by a media columnist, but an assessment made from someone who was at the birth of the Organization, instrumental in its negotiations with the international oil companies, and most importantly, was at the height of decision-making. For him to declare OPEC 'dead' was no small matter. Since the late 1980 s, specifically since the 1986 price collapse, many had doubted OPEC's efficacy, but not its survivability. But when former officials, such as Chalabi, utilized this narrative, the continual survivability of the Organization was now universally beginning to be questioned. The wider market conditions was simply not conducive to the Organization's recapturing effective influence over supply and demand dynamics, as it had previously done in the past.

\section{Outside Powers}

The key, determining factor behind the changing market conditions was the dominance that the US acquired and exercised within the international system in the aftermath of the Soviet demise. It is important to remember that OPEC's very formation was in many respects grudgingly accepted by the US, primarily because of Cold War dynamics leading Washington towards a policy of neutrality to oil producing countries in the developing world. The fear of the Soviet Union exploiting the economic and security

${ }^{442}$ Fadhil J. Chalabi, "Opec: An Obituary," Foreign Policy, no. 109 (1997): 126-40. 
vulnerabilities in OPEC Member States created a major sense of caution in the US. But in this period of American unipolarity, ${ }^{443}$ there was no reason for the US to exhibit a sense of caution towards producers. The Soviets had been defeated, and the Russian Federation that took its place was a bankrupt entity incapable of running its own affairs, let alone threatening American interests. This allowed American and Western firms to look towards the newly independent Central Asian countries for possible future energy investment.

For the international oil companies (IOCs) who a generation prior had lost their concessions and effective control over pricing dynamics to OPEC, the collapse of the USSR and the opening up of energy-endowed states on the Russian lower periphery presented a major investment opportunity. The world of the old concession system was long gone and could not be resurrected - at least in terms of providing the IOCs the favorable investment conditions they once enjoyed. Yet, the years that had transpired from the end of the concessionary systems and loss of control over pricing had transformed the role of the major IOCs. Though at first, the end of the old system was seen as a loss to the IOCs, they quickly adjusted to the new realities of the market, and thus, with remarkable success, changed the very nature of their global corporate identities. This evolution witnessed the IOCs transforming from the dominant concession holders with total control over the entire oil industry in a particular country to being global contractors to diverse National Oil Companies (NOCs) of hydrocarbon-endowed countries. The main factor that allowed this transition was the significant technological gap that existed between the IOCs, which in essence created the modern oil and natural

${ }^{443}$ Charles Krauthammer, "The Unipolar Moment," Foreign Affairs 70, no. 1 (1990). 
gas industries, with that of the National Oil Companies, which were mostly a product of the latter half of the $20^{\text {th }}$ century. By the end of the Cold War, it was this very relationship, which the IOCs were forced into, that made up the entire structure of the global oil industry.

Because of the technological gap, even staunchly nationalist NOCs that were highly suspicious of foreign firm involvement in their oil sectors, ultimately had to consider an invitation to the IOCs in hopes of not only enhanced output from traditional wells and future discoveries, but also for more efficient output and environmentally sound exploration. This new dynamic gradually created a 'neo-concessionary system' that was based not on physical domination of the producing country or its political apparatus, but one of enticement through enhanced production and export prospects. Eventually, in hopes of recovering from the disastrous 1980s, OPEC Members would either enhance their cooperation with the IOCs, such as the case with Saudi Arabia and its Persian Gulf monarchial allies, but also nationalist price hawks such as Algeria, Iran, and Libya.

With the confluence of the massive technological gap between NOCs and IOCs and the new sources of supply because of the Cold War's end, for the first time in a generation, oil firms gained tangible leverage in the wider global oil industry.

\section{The opening of the Post-Soviet Space: New Sources of Energy}

The years immediately after the Soviet collapse, once dominant actors, particularly Russia, and to a lesser extent China, were quite helpless in obviating newly independent Central Asian Republics from inviting both foreign capital and polices into 
the region. ${ }^{444}$ The Russian Federation's attempt to jettison its former affiliations with fundamentally weak, and unstable regimes in oil-rich Central Asia, exemplified in its reoriented "common European home" policy, ${ }^{445}$ laid the groundwork for the cooption of Central Asia by the West via energy firms. Moreover, Russia's catastrophic transition from a command to a market economy mired the state in domestic unrest and fiscal inertia for almost a decade, ${ }^{446}$ essentially causing a paralysis in its geostrategic considerations. It was during this very time that advocates of Western economic and political intervention in the post-Soviet space were at its zenith, ${ }^{447}$ buttressed by prospects of both lucrative enhancement as well geopolitical gains. ${ }^{448}$

Whether motivated by apprehension concerning their newly found independence or a sincere desire to seize a moment when the traditional dominant actor was weak, most Central Asian countries, particularly Georgia, the Ukraine, Azerbaijan, and Kazakhstan, overtly courted Western capital, technology, and diplomatic relations. This was chiefly due to their own internal inability to access the vast amount of hydrocarbons within their respective territories and also not possessing the technology to export the hydrocarbons to the global market. With these events, by the turn of the century, the West's relationship with dependent new states of Central Asia firmly granted it a foothold in Eurasia that it

\footnotetext{
${ }^{444}$ Goldman, Petrostate: Putin, Power, and the New Russia, 55-93.

${ }^{445}$ Soviet Premier Mikhail Gorbachev advanced a 'Common European Home' policy in order to set a strategic repositioning with the Soviet Union's European neighbors and reduce to traditional tension. PostSoviet Russian leader, Boris Yeltsin, largely continued this policy. See,: Neil Malcolm, "The 'Common European Home' and Soviet European Policy," International Affairs (Royal Institute of International Affairs 1944-) 65, no. 4 (1989): 659-76.

${ }^{446}$ J.E. Stiglitz, Globalization and Its Discontents (W. W. Norton, 2003), 133-65.

${ }^{447}$ Zbigniew Brzezinski, “A Geostrategy for Eursasia,” Foreign Affairs, September/October 1997, 50-64.

${ }^{448}$ Mehmet Ogütçü, "Eurasian Energy Prospects and Politics: Need for a Fresh Perspective," Cahiers d'Etudes sur la Méditerranée Orientale et le monde Turco-Iranien 19(January 1995).
} 
never possessed prior to the Soviet demise. ${ }^{449}$ And as new supplies from Central Asia and the Caucuses came online, it was this very strategic foothold that helped perpetuate the very market conditions that OPEC and other oil producers, like Russia, were suffering from throughout the 1990s.

\section{The New Consumer Base: South and East Asia}

But as the 1990s drew to a close, the role of outside powers, even in this age of unipolar American domination, was not just relegated to the US. The exponential increase in consumption patterns in the developing world, particularly due to massive development in China and India, played a decisive impact on the gradual rise in oil prices (see Figure 5.4). ${ }^{450}$ For all the complexities surrounding Chinese and Indian industrialization, past and present, the concept of energy security as it relates to their post-Cold War development was far more elemental. Distinctively for China, as internal development endeavors, coupled with the international pressures for continuing modernization, transformed it into an oil importer in $1993,{ }^{451}$ Beijing, since 2000, witnessed imports triple, with rising consumption every year. ${ }^{452}$ By 2030, the International Energy Agency predicts Chinese consumption far exceeding that of the European Continent, and taken together with East Asian economies and that of India's, consumption from the East will most likely surpass both North America and Europe

\footnotetext{
${ }^{449}$ Sarah L. O'Hara, "Great Game or Grubby Game? The Struggle for Control of the Caspian," in The Geopolitics of Resource Wars, ed. Philippe Le Billon, 138-160 (New York, NY: Frank Cass, 2005).

${ }^{450}$ Fareed Zakaria, The Post-American World (New York, NY: W.W. Norton \& Company , 2008), 88-100.

${ }^{451}$ Xuanli Liao, "Central Asia and China's Energy Security," China and Eurasia Forum Quarterly (Central Asia-Caucasus Institute \& Silk Road Studies Program) 4, no. 4 (2006): 61-69.

${ }^{452}$ Zha Daojiong, "China's Energy Security and Its International Relations," The China and Eurasia Forum Quarterly 3, no. 3 (November 2005), 41.
} 
combined by the same period. ${ }^{453}$ For India, the experience with energy security, chiefly with the OPEC crisis of 1973 had differing ramifications as compared to Western industrialized countries. Although at the time, Indian energy consumption was low in comparison to industrialized counterparts, it affected key sectors of India's economy, forcing the country towards enhancement of energy diversification efforts with both traditional and new partners. ${ }^{454}$

As Figure 5.4 shows, the largest growth in consumption of oil in the post-Cold War era has been in Asia. Therefore both of these mass populous countries, particularly since the turn of the century, ambitiously courted energy rich countries to secure access. ${ }^{455}$ The biggest ramification of the Chinese and Indian search for energy is that it has rendered their own NOCs as alternatives to the technologically savvy Western firms. Although the state owned agencies of both these countries are still years behind their Western counterparts as it relates to better efficiency in the upstream sectors, and certainly on transportation, it is their sheer internal market demand that has enticed many producing countries, in OPEC and beyond. This had been particularly important for producing countries that have no access or have been denied access to Western technology. For OPEC during this period, this would have been Libya, Baathist Iraq, Iran, or even Algeria. As consumption gradually increased in the first decade of the 2000s, OPEC Member States, though still unable to collectively act on strategic matters, gradually regained some market leverage and diversification options because of China

\footnotetext{
${ }^{453}$ Christopher Len, Energy Security Cooperation in Asia: An ASEAN-SCO Energy Partnership?, Institute of Southeast Asian Studies (Energy Perspectives on Sinagpore and the Region, 2007), 157.

${ }^{454}$ Raju G. C. Thomas, "Energy Politics and Indian Security," Pacific Affairs 55, no. 1 (Spring 1982): 33.

${ }^{455}$ See: Thrassy N. Marktos, China's Energy Geopolitics :The Shanghai Cooperation Organization and Central Asia (New York, NY: Taylor \& Francis Routledge, 2009).
} 
and India. Not only did this provide the energy producers with new opportunities of fiscal gain, but also explicitly tied them to the internal developments of many rising developing countries.

\section{American policy failure: Fallout from interventions in Iraq and Afghanistan}

With the awesome power that the US did inherit after the end of the Cold War, came more vulnerability. It is here where the 9/11 attacks and the US invasion of Iraq would come to affect the internal functionality of OPEC. When the United States entered the Middle East subsystem militarily in the first Gulf War, to counter and contain an irredentist Iraq, it introduced itself, more than ever in its historical dealings with the region, as both a regional country and a hegemon, becoming an integral actor within the Middle East. From that decisive victory in the spring of 1991, the American role gradually aggrandized to being the sole guarantor of regional stability, expanding its military apparatus in the Gulf Cooperation Council states (GCC), heavily arming their militaries, increasing frequency of US naval operations in the Persian Gulf, as daily sorties kept intact the no-fly zones of an increasing emasculated Iraq. For the next decade, the US strategy remained unvaried as the region witnessed a host of economic and political revisions that ultimately laid the groundwork for current regional realities: American attempts to implement the Oslo Accords (at the time seen as a breakthrough in the perennial Israeli-Palestinian conflict), Turkey's socio-economic progression, the beginnings of the spike in oil prices (now seen as a threshold to the enhancement of the sovereign wealth funds of many Persian Gulf States), and the protracted strangulation of Iraq.

However, a parallel undercurrent was also taking shape beneath many US 
sponsored peace efforts between Israel and the Palestinians, economic development in regional US-aligned nations, and the common wisdom that promulgated the stability of the status quo. Over time, the conventional narrative began to unravel in the face of the Palestinian Intifada of 2000, the Israeli withdrawal from Lebanon in that same year leaving Hezbollah in a much stronger position, the American inability to subjugate Iran with economic warfare, the overall failure of President Clinton's peace efforts at the end of his tenure, and Afghanistan's descent into fratricide (with patches of the country under the firm grip of the Taliban). Moreover, the no-fly zones implemented by the coalition forces as a result of Saddam's proclivities towards his Shīah and Kurdish populations led to the ipso facto formation of two semi-autonomous regions within Iraq proper - the forerunner for the difficulties that the US would face in the current occupation. The September $11^{\text {th }}$ attacks not only extended the military dimensions of the United States within the region, but also transformed the American accepted wisdom on how stability and US objectives could be sustained in the Middle East and, fundamentally altering the logic behind the use of force.

It was in this backdrop that the US interventions in Afghanistan in 2001 and Iraq in 2003 need to be measured against. Though the US emphatically succeeded in overthrowing the Taliban regime of Afghanistan, the host government of Al-Qaeda's apparatus, and the entrenched Baathist autocracy in Iraq, the cost for American actions has yet to be fully tallied. To date, the financial expenditures of the wars have been projected to tally at $\$ 4-6$ trillion. ${ }^{456}$

These expenditures appear at a time where the American economic paradigm of

\footnotetext{
${ }^{456}$ Linda J. Bilmes, "The Financial Legacy of Iraq and Afghanistan: How Wartime Spending Decisions Will Constrain Future National Security Budgets," Harvard Kennedy School Faculty Research Working Paper Series, no. RWP13-006 (March 2013).
} 
governance has been openly critiqued internationally (by reason of exorbitant national debt and an unregulated financial sector). Moreover, the human costs of the wars have approached 7,000 coalition deaths (of which almost 5,000 are American), coupled with an untold amount of Iraqis and Afghans who have since perished. As the years have passed since the initiation of the Iraq conflict, numerous historical analyses and commentaries, both in print and in film, emanating from an eclectic pool of observers, have been produced regarding American regional intervention. Yet, no matter how critical or laudatory they may be to the current state of US military involvement in the Middle East, there is an inferred harmony amongst them; that is, outside of conventional air power, with which the US has unquestioned superiority amongst all other actors, American power projection capability has weakened - some claiming dramatically so.

While the war with Saddam was a result of the new, post-9/11 approach that the United States adopted towards the Near East (i.e. preventative military intervention), it was also a byproduct of the efficiency and speed that characterized the early months of the US intervention into Afghanistan, Operation Enduring Freedom. Consequently, with the intervention in Iraq, and the rapid fall of Saddam's fragmented military, the US perception of its regional position was arguably at its zenith. Nevertheless, this assessment was at best incomplete, and now, in hindsight, grossly inaccurate. With the US transitioning from a fighting to an occupational force, the American claim, both within Iraq and Afghanistan, was becoming suspect.

\section{Intrastate dynamics}

The US interventions in the Middle East would create the conditions where the most consequential internal state dynamics that transpired during this period was in the Iraqi 
political scene. This was not only because of Iraq's importance in OPEC as it pertains to collective production and decision-making. The US intervention in Iraq and the creation of a new post-Baathist political system would begin the process of bringing back Iraqi production capacity in the global market. And from these internal events in Iraq, subsequent regional ramifications that would affect the entire Middle East would gradually lead to the irrevocable altering of the balance of power, setting the stage for a shift of power in OPEC consensus, and creating new alliances in the region and beyond.

\section{Iraq}

In Iraq, as the Coalition Provisional Authority (CPA) systematically dismantled the entrenched Baathist socio-political infrastructure, the fragility of the state itself was glossed over while the strength of civil society was idealistically overestimated. What is more, the existence of two semi-autonomous entities within Iraq for more than a decade, specifically the Northern Kurdish portion, had greatly eroded the notion of an Iraqi state. ${ }^{457}$ In other words, if there had ever existed a unitary sense of Iraq, the years that followed the 1991 defeat of Saddam Hussein had now questioned that assumption to many differing factions within the country. The incapability of the US military, the CPA, and Iraq's fragile elected government to restore domestic order as mass looting, sectarian war, and internecine bloodshed continued, manifested the occupation's shortcomings. Although the violence within Iraq has significantly declined since late 2007, the overarching political reconciliation amongst the country's disparate factions has yet to be realized, still lacking the qualities of political permanence. If violence were to return to

${ }^{457}$ Liam Anderson, "The Perils of Nation-Building in Iraq: The Implications for U.S. Policy in the Middle East," in Great Powers and Regional Orders: The United States and the Persian Gulf, ed. Marcus Kaim, 183-196 (Burlington, VT, 2008). 
previous levels, the threat of the Iraqi state being ripped asunder still looms on the horizon, inviting intervention by regional actors, particularly, Turkey, Saudi Arabia, and most certainly Iran. Additionally, the deep sense of frustration amongst many Westernallied Arab regimes, chiefly the Arab states of OPEC, about regional systemic alterations associated with US actions acts as a compounding force upon an increasingly questionable American regional strategy.

But with the Iraq intervention, although the political and security situation within the country significantly worsened in the occupation period, Iraq's oil sector did begin the long process of revitalization. This dynamic not only affected the country's exports potential, but would also alter its power position within OPEC, a process that is still underway. For the first time since the 1970s, Iraq would once again become a magnate for major oil firms, not just the traditional technologically advanced Western multinationals, but increasingly NOCs from China, India, and the African continent. ${ }^{458}$ Ironically, the same set of factors that has kept Iraq's political system paralyzed, which directly affects its internal security, has also, by default, created the conditions for mass investment from abroad. These factors are the inability of the central government in Baghdad to unify state policy vis-à-vis oil production, differing perspectives on oil exports held by varying regions of the country, and the larger question of decentralization/federalism. As result, what differing regions of Iraq have done, most notably the Northern Kurdish-speaking portion of the country, is to invite foreign capital and expertise into their regions so that their oil production would not be dependent upon Baghdad, whom degrees of autonomy is wanted. The result has been massive investment

${ }^{458}$ See: Iraq Oil Almanac: An OpenOil Reference Guide, http://openoil.net/oil-almanacs/ 
of foreign oil companies, such as BP, ExxonMobil, and Chevron's presence in Northern Iraq, NOCs, such as Russia's Gazprom and the China National Petroleum Corporation (CNPC) throughout the country, while smaller European and Asian firms fill in the gaps.

As Figure 5.3 shows, since 2003, despite the political and security chaos in Iraq, the country has steadily made measured advances in oil production. Indeed, the only impediment that has kept Iraq from advancing further in its oil production has been the political paralysis of its new, post-Baathist leadership. And with this advance in production, by reason of the technological influx that has come into the country, has come a revision of the country's oil reserves. According to OPEC's 2013 Annual Statistical bulletin, Iraq now owns roughly $11.7 \%$ of the proven oil reserves in the world, making it the fourth in OPEC and fifth in the world. ${ }^{460}$

\section{Venezuela}

As the US intervened in Iraq, internal changes were also taking place in Venezuela. Historically, successive Venezuelan governments not only were considered reliable partners for the US in regional trade initiatives but also had cooperated, often times intensely, on oil policy. With the rise of Hugo Chavez in the late 1990s, the US would gradually begin to realize that its relationship with Venezuela was to undergo a significant change. Chavez's democratic rise was not just an internal issue for Venezuela, ${ }^{461}$ but had serious repercussions in Latin America. For OPEC in particular, Chavez and

\footnotetext{
459 Ibid.

${ }^{460}$ See: OPEC statistical data http://www.opec.org/opec web/en/data graphs/330.htm \& EIA (the US Energy Information Agency) statistical data http://www.eia.gov/countries/index.cfm?view=reserves

${ }^{461}$ R. Gott, Hugo Chavez and the Bolivarian Revolution (Verso, 2011), 143-216.
} 
his Bolivarian allies within Venezuela sought to utilize the country's vast oil reserves and export potential for social programs at home. ${ }^{462}$ Yet, to do that effectively, Chavez sought to revitalize the Venezuelan presence in OPEC, not just ceremonially but in terms of decision-making. Though a founding Member, the decision-making influence of Venezuela in OPEC had long declined, primarily because it could not keep up with initially Iranian, and then Saudi output. 463

Chavez's rise, first from his failed coup-attempt in the early 1990s with his military colleagues, ${ }^{464}$ then to the civilian-led populist campaign that brought him to power, fundamentally challenged the entrenched ruling elite that had run Venezuela for more than two generations. However, though the Chavez administration would become known as revitalizing the socialist model in the $21^{\text {st }}$ century, his initial economic and social policies were quite moderate, only to be considered center-left. ${ }^{465}$ It was only after a series of constitutional referendums, and particularly after Chavez's survival from a 2002 coup attempt, that his administration really embarked on socialist policies at home, and supporting like-minded governments abroad.

In order pay for the increased expenditures at home, the Chavez administration understood that significant changes needed to be implemented to the country's oil sector, which had usually relied on Western capital investment and technology - even since nationalization. And since the coup attempt against him had severally degraded his once

\footnotetext{
${ }^{462}$ N. Kozloff, Hugo Chavez: Oil, Politics, and the Challenge to the U.S (Palgrave Macmillan, 2007).

${ }^{463}$ R. Gott, In the Shadow of the Liberator: Hugo Chavez and the Transformation of Venezuela (Verso, 2000), 6-54.

${ }^{464}$ Jason Seawright, Party-System Collapse: The Roots of Crisis in Peru and Venezuela, (Stanford University Press, 2012), 160-170.

${ }^{465}$ Gregory Wilpert (2007). Changing Venezuela by Taking Power: The History and Policies of the Chávez Government, (Verso, 2007), 3-4.
} 
normal relations with the US and much of the West, Venezuela gradually reached out to both Russia and China for technological assistance with its oil industry, and to other fellow OPEC NOCs.

However, increased Venezuelan production was simply not enough. In order to change the dynamics of oil as it pertains to the Venezuelan economy, and to subsidize what was becoming an increasingly activist foreign policy, the Chavez administration had to reach out to OPEC. Throughout the early years of his tenure, Hugo Chavez would become a renewed voice of collaboration among Member States that often did not trust each other. Through Venezuelan initiatives, harkening back to Organization's formation, Caracas introduced new ideas for cooperation to the Member States that had undergone traumatic years prior. Chavez's efforts did bring forth modest results. Beginning in 2001, oil prices began their slow climb back. It was during this very period that OPEC countries would gradually begin renewed cooperation on price defense measures and a renewed, but ultimately unsuccessful, commitment to stick by their quota responsibilities and not overproduce. Chavez's ability to personally corral the diverse leaders of OPEC countries greatly assisted the Group in arriving at some form of tactical cooperation.

\section{Interstate relations}

By 2004, what started with Venezuela's initiative at short-term, tactical compromises in order to increase revenue broadened out into a more functional, working relationship among Member Countries. The biggest item on the agenda was to recapture OPEC's ability to fundamentally influence global supply and demand dynamics. And price defense measures, a failing legacy of the 1980s and 1990s, was simply not enough. OPEC's post-1980 policy of scaling production, either through measured cutbacks via the 
quota system or more extreme measures, had rendered the Organization's power over the market a short-term enterprise. In the mid-1980s and sporadically in the 1990s, this policy, often times, had virtually no effect because of the oversaturation of the market. But by 2004, OPEC gradually began to realize that their efforts to recapture influence would need the Organization to start implementing long-term strategies that would benefit all consumers, as opposed to short-term measures intended to protect producers.

At OPEC's $132^{\text {nd }}$ meeting in Vienna, Austria in September of 2004, Member States began to implement this very concept. In reacting to the increasing oil prices (which would only rise further in the years ahead), OPEC began the process of once again regaining influence over prices, with the secondary goal of presenting the Organization as a force for stability in the global economy. In their press release, OPEC revealed that the Group would be unilaterally increasing production to offset prices, which was a stark contrast from past behavior:

Having reviewed the current oil market, the Conference noted that higher crude oil prices are a result of such factors as the demand surge earlier in the year, especially in North America, China and Asian countries, geopolitical factors and concern about adequacy of spare capacity to meet possible supply disruptions, exacerbated by the significant impact of speculators and by tightness experienced in the downstream industry. It also observed that OPEC's timely actions had been effective in ensuring that the market remains well supplied, resulting in commercial OECD stocks build-up to levels close to normal, thus succeeding in reversing the OPEC Reference Basket price trend down to levels around $\$ 38 / \mathrm{b}$. In the light of the foregoing, the Conference decided to raise the OPEC production ceiling (excluding Iraq) by $1.0 \mathrm{mb} / \mathrm{d}$, to $27.0 \mathrm{mb} / \mathrm{d}$, with effect from November 1, 2004, in order to bring prices down further to a more sustainable level, whilst, at the same time, vigilantly monitoring market developments. In taking this decision, the Organization reiterated its commitment to take action to stabilize the market at prices reasonable to both producers and consumers. Taking into consideration the market outlook for 2005, with its concomitant uncertainties, especially in the first and second quarters, the Conference further decided to convene an (Extraordinary) Meeting in Cairo, Egypt, on December 10, 2004 to review 
market developments and take whatever measures are deemed appropriate at that time. Taking this decision in recognition of the importance of maintaining oil market stability for the benefit of the world economy, as well as consumers and producers, the Conference expressed its expectation that non-OPEC oil producers will take concrete measures to actively share with the Organization the responsibility of maintaining price and market stability in 2005 and thereafter. ${ }^{466}$

OPEC's actions in 2004 and in subsequent years to balance crude supply to meet demand were neither new nor revolutionary. But the rediscovery of this very concept, and in many respects, this responsibility of the Organization to the global economy, after almost twenty years of infighting, consensus breakdown, and paralysis was neither expected nor predicted. This was particularly true in light of the many obituaries that were written for the Organization, by friends and foes alike.

In the following year, OPEC's Acting Secretary General, Adnan Shihab-Eldin, sought to assure markets on OPEC's role in price stabilization. As prices were gradually rising, he reiterated "OPEC's commitment to ensure adequate supplies", affirming "the Organization stands ready to take the necessary decisions to maintain market stability." ${ }^{467}$ Moreover, in the same period, OPEC made efforts to reach out to other important international organizations, exemplified in their third meeting with the International Energy Agency in 2005 concerning the energy outlook in the Middle East and North Africa. ${ }^{468}$ More importantly, the Organization reached out the European Union to facilitate a broader dialogue on energy concerns, and in June of 2005, held its first

\footnotetext{
${ }^{466}$ Organization of Petroleum Exporting Countries. Annual Report. (Organization of the Petroleum Exporting Countries, 2004), 49-50.

${ }^{467}$ Organization of Petroleum Exporting Countries. Annual Report. (Organization of the Petroleum Exporting Countries, 2005), 47.

${ }^{468}$ Ibid, 52.
} 
official European Union-OPEC Energy Dialogue. ${ }^{469}$

But the Organization's ability to continuously act as a stabilizer of global prices had its limits, ultimately reaching its potential in 2006. In virtually every press release of that year, as prices were steadily rising, OPEC would continuously reaffirm that the market was well supplied, and thus there was no need for additional output into the market. ${ }^{470}$ And in July of that year, as price increases no longer could be ignored, the Organization addressed this new dynamic in the global economy:

OPEC has noted with concern the strong upward pressure on oil prices of the past few days and wishes to reassure the market of its continuing commitment to order and stability, to the benefit of producers and consumers alike. Geopolitical developments, over which OPEC has no influence, have been behind this sudden rise in volatility, and these have come at a time when the market was already out of line with today's supply and demand fundamentals, with speculation playing a significant role in driving up prices. It has also occurred in spite of the fact that the market remains well-supplied with crude, and, with crude volumes continuing to enter the market well in excess of demand, OECD stocks are above their five-year average levels. This healthy state of the upstream sector has been very much due to OPEC's abiding commitment to market stability, with prices at fair and equitable levels, in support of sound world economic growth, in particular with regard to the needs of developing countries. OPEC's MCs have increased crude oil production substantially since the recent heightened state of volatility first manifest itself in spring 2004, as well as accelerating their plans to bring onstream new production capacity to meet continued demand growth and reestablish a comfortable cushion of spare capacity. However, to be truly effective in increasing stability and moderating prices, OPEC requires the full support of the other major players in the market, on both the producer and consumer sides. All parties gain from market stability and so all parties must contribute to it. In welcoming the major advances that have been made in dialogue and cooperation within the industry in recent years, $O P E C$ recognizes the potential for this to provide tangible benefits in the present volatile market conditions. ${ }^{471}$

\footnotetext{
${ }^{469}$ Ibid.

${ }^{470}$ Organization of Petroleum Exporting Countries. Annual Report. (Organization of the Petroleum Exporting Countries, 2006).

${ }^{471}$ Ibid. 52.
} 
Subsequently, in its September 2006 meeting, the Organization essentially reaffirmed this view by stating "crude oil supply in recent years has continued to exceed growth in demand - the rebound in non-OPEC supply in 2007 is predicted to be at its highest level since 1984 - and that market fundamentals indicate a clear imbalance between supply and demand". ${ }^{472}$ OPEC was confirming that though they will not allow systemic shocks, such as 1973 or 1980 to occur again, this new era of gradual price increases was one in which they felt not only comfortable with, but would most likely defend: "the Organization will continue its proactive policy of supporting market stability by restoring a balance between supply and demand, at prices reasonable to both producers and consumers and conducive to continued world economic growth". ${ }^{473}$

This same approach remained OPEC's policy throughout 2007, exemplified by its familiar refrain that "oil markets remain well supplied and market fundamentals do not require any additional supply from the Organization at this time". ${ }^{474}$ But as prices climbed to the highest they had been in over a generation, OPEC's cautious, albeit content approach with more revenue for Member States, needed to provide an answer for the changing market conditions. OPEC's Secretary General, Abdalla Salem El-Badri, was ultimately compelled to defend the Organization in the face of insinuations about purported responsibility by the Group for rising prices:

\footnotetext{
${ }^{472}$ Ibid. 53.

${ }^{473}$ Ibid.

${ }^{474}$ Organization of Petroleum Exporting Countries. Annual Report. (Organization of the Petroleum Exporting Countries, 2007), 48.
} 
High oil prices, which we are now witnessing, are not a consequence of insufficient crude supplies. Inventory data, continues to demonstrate that crude stocks are ample. US crude stocks are now at nine year highs, while $O E C D$ stocks are healthy, and are above their five year average. This data, therefore, shows us very clearly, that current high oil prices are not in any way related to crude supplies. Inadequate refinery capacity, ongoing glitches in US refinery operations, geopolitical tensions and increased speculation in the futures market are, however, driving high oil prices. So even if OPEC were to supply the market with additional crude at this time, these refinery-related problems mean that any extra barrels would not be refined into products. OPEC is closely observing developments in the global oil market, including the current price trend. If the Organization sees any evidence that oil prices are rising because of a shortage of crude, which does not exist at this time, it will not hesitate to act immediately to alleviate any such deficit. ${ }^{475}$

El-Badri analysis concerning limited refining capacity in North America, which incidentally was also occurring in Europe and the Far East, in addition to the geopolitical tensions in the Middle East were fundamentally correct. American investment in refining capacity had lagged, primarily because in the immediate years of the post-Cold War era, the rapid and massive consumption trends from China and India were simply not expected. Therefore, the US, with its European counterparts, not expecting the rising tide of consumption post-2000, allowed its refining capacity to stagnate. Moreover, as mentioned previously, the Middle East, in the aftermath of the US intervention in Iraq, was a different place. And the 2006 war between Israel and Hezbollah in Lebanon, in that the latter fought the technologically advanced Israeli military to a standstill, was not only a turning point in regional politics, but also what many considered the heralding of new era of conflict.

But pointing out these issues, although they were temporary, did little to relieve the situation in the global oil market. As 2007 drew to a close, OPEC increasingly

\footnotetext{
${ }^{475} \mathrm{Ibid}, 52-53$.
} 
became aware that many in the global economy were attributing the substantial increase in the price of oil to OPEC's inaction. These concerns, once again, forced OPEC's Secretary General to the podium"

OPEC is carefully watching developments in the oil market and has observed with concern the recent escalation in oil prices. While the Organization does not favor oil prices at this level, it strongly believes that fundamentals are not supporting current high prices and that the market is very well supplied. There has been no interruption in crude supplies and OECD commercial inventory levels remain above five-year levels. Forward cover, which stands at 53.5 days, is at a comfortable level. The rising oil prices which we are currently witnessing are, however, largely being driven by market speculators. Persistent refinery bottlenecks and seasonal maintenance work, ongoing geopolitical problems in the Middle East and fluctuations in the US dollar, also continue to play a role in pushing oil prices higher. Additional political tensions, seen during recent days, are also pressurizing oil prices upwards. OPEC continues to strive for a balanced market and a fair price that is favorable for both consumers and producers. As part of its mission to keep the market well supplied, and as agreed in September, the Organization will raise output by 500,000 b/d from 1 November 2007. Member Countries are in the process of implementing their share of this increase. OPEC will continue to monitor the global oil market and will respond to any supply disruption, so as to ensure the market remains well supplied during the winter months.

The decision to increase output by half million $\mathrm{b} / \mathrm{d}$ was thought by the Organization to at least have a psychological effect on the global economy, possibly to roll back the influence of speculation about future supply. An indirect, albeit significant, result of the rising consumption patterns coming from China and India was the rebirth of the 'exhaustibility theory' of the 1970s. This new variation was labeled as "peak oil", popularized by the fusion of two interconnected strands of thought: resource wars and the ramifications of climate change. ${ }^{476}$ As these theories occupied mainstream thought in

\footnotetext{
476 See: T. Homer-Dixon, Carbon Shift: How Peak Oil and the Climate Crisis Will Change Canada (and Our Lives) (Random House of Canada, 2011); P. Roberts, The End of Oil: On the Edge of a Perilous New World (Houghton Mifflin, 2005); B. Abdullah, Peak Oil Paradigm Shift: The Urgent Need for a
} 
both the policy-making and business communities, it was important for the Organization to show it had at least attempted to pacify prices. But as 2008 began, and well into the summer, limitations in global refineries, Middle East tensions (including heightened tension between the US and Iran), and open conflict between Russia and Georgia (which created additional supply disruption fears), all compounded by speculation, drove prices to their highest level since the beginning of the Iran-Iraq war. Yet with the arrival of the US financial crisis in the fall/winter of that year, drying up credit in advanced economies, slowing consumption down and significantly reducing oil prices, OPEC once again, entered into a period of uncertainty.

\section{Ending the Rebalancing Era}

Nevertheless, the newfound tactical cooperation amongst Members brought about tangible, positive results for the Organization during this period, allowing them to take advantage of the circumstances surrounding global oil supply and demand dynamics. However, uncertainties about the accommodation of the new Iraq (and its economic and political ramifications) has still kept OPEC from returning to its pre-1980s unity. From a political standpoint, the rise of a new political system in Baghdad has evoked the ire of Saudi Arabia and their Persian Gulf allies, ostensibly because it would empower a political group in Iraq that's always been disenfranchised in the former countries. From an economic standpoint, the full integration of Iraq in the global economy would gradually erode the power of OPEC's traditional major producers, of which Saudi Arabia has long been dominant.

Sustainable Energy Model (Medianet Limited, 2005); M.T. Klare, Resource Wars: The New Landscape of Global Conflict (Henry Holt and Company, 2002). 
Needless to say, though these lingering political disputes are still extant, they did not impede the slow recentralization of OPEC. Even though the traditional Iranian/Saudi divide is still alive, along with the newfound concerns of Iraq from specifically the Persian Gulf monarchies, Member States were able to take advantage of the remarkable growth in the global economy from 2001-2008. During this period, the altered nature of the global oil industry, primarily the rapidly growing consumption from East, allowed OPEC Member States to reap economic windfalls that it hadn't seen since the end of the 1970s. For many OPEC Members, the hyper infusion of capital into their economies, because of the high price of oil, would help create the large sovereign wealth funds that would be crucial during the current, still unnamed era, where many of OPEC's Arab Members have to deal with the fallout of the Arab Spring of 2011-Present, a changing regional balance of power, shifting relations with the US, and changing demographics. 


\section{CONCLUSION}

The post-2008 phase of OPEC's institutional life has yet to be defined. This era will most likely take years to fully take shape, and within its wider context, several key trends and factors - possibly which are entirely new - will affect how OPEC behaves. However three particular trends that will be crucial in how this current phase of OPEC's development evolves.

The first concerns the permanent fallout of the financial crisis that began in the fall of 2008. While the ramifications of this crisis has touched virtually every region of the world, the most consequential factor that would affect OPEC and the nature of the oil industry is what the financial crisis will do to consumption trends. Will certain regions of the world that were growing or slated for growth before the financial crisis, no longer grow, and thus consume less energy?

As Figure 5.4 shows, the consumption patterns for 2009 dropped from the prior, clearly indicating the impact of the global financial crisis on world oil demand. And as expected, with this consumption drop, in the face of steady and growing supply, crude oil prices for 2009, as shown in Figure 5.2, significantly fell. Although they have recovered since the crisis, the recovery has been anemic and tenuous, as the health of diverse markets, chiefly the EU, still remain in doubt. For OPEC in particular, the immediate years after the financial crisis has seen prices partially rebound, but have also severally

affected the recapturing of its market share recover. As Figure 5.1 shows, OPEC's market share of global oil production dropped 5\% in 2010 from 2008 figures. 
On the reverse side, will new consumption patterns from Asian economies create a new relationship with OPEC Members, in the same way that the US and UK forged a bond with the House of Saud or other Persian Gulf monarchies in the early part of the $20^{\text {th }}$ century? In the last decade, a fundamental shift has happened in the direction of oil exports from the Persian Gulf. Though Venezuelan exports will always have a heavy presence in the Western Hemisphere, for the other Members of OPEC, exports to the Far Eastern economies (India, China, South Korea, Japan, etc.) rose astronomically. By the time of the 2008 financial crisis, most Persian Gulf exports were travelling to Eastern markets.

Such a change in consumption patterns, if history is a guide, will invariably alter the relationship between certain OPEC Member States (such as Saudi Arabia and their Persian Gulf allies) with that of the United States. Moreover, the recently renewed tensions between the Russian Federation and the US and EU over Ukraine will undoubtedly affect OPEC Member States' export policies. Since the 1979 Iranian Revolution, there has been a systematic US attempt, aided and facilitated by the EU, to reduce and weaken Iranian oil exports.

This dynamic indirectly led to Europe's reliance on Soviet, and then later Russian oil and natural gas exports. As a result, for Russia, Europe had been a market they had dominated for the entirety of the post-Cold War period, having no real viable rival that could help Europe diversify. Yet, if the relationship between Russia and the EU deteriorates - a likely possibility in the wake of Russia's occupation of Ukrainian territory - Europe would then need to reach out to viable alternative hydrocarbon suppliers. Because of its location, the size of its oil and natural gas reserves, and relative 
ease of transport to Europe, Iran is the most likely and plausible alternative. But for the EU to make this diversification decision vis-à-vis the Iranians, a necessary rethinking of the sanctions regime on Iran needs to happen.

The second factor that would affect the current era of OPEC's institutional life concerns the ultimate fallout from the Arab Revolutions of 2011 to the present. As it is virtually impossible to separate Middle East politics from OPEC's functionality, decision-making, and ultimately behavior, the trajectory of the Arab Spring, and whether they will impact other OPEC Members, as it violently did in Libya in mid-2011, will be crucial for the Arab Member States and also for the Organization as a whole. For the Arab Members of OPEC that have or are currently being affected by the fallout of political turmoil, the main impact has been a halt or reduction in production. For Libya in particular, the protests that developed in early 2011, which coincided with other protests in North Africa, eventually led to civil war, NATO intervention into the country, and a whole scale regime change. As a result, large swaths of Libya's infrastructure were destroyed, oil production plummeted, and the Libyan oil industry, including personnel, was severally damaged. Though there is now an elected government in Libya, its ability to function, to control Libyan territory, and operate Libya's critical infrastructures, especially its oil sector, is extremely limited.

For Arab Members that have yet to experience the Arab Spring or fear its arrival, oil revenue directed towards calming social unrest has totally changed their traditional approaches to prices and profits. For Saudi Arabia in particular, the current, ongoing Bahraini political instability, which required Saudi and UAE troops to enter the country in support for the Bahrain monarchy, has a distinct possibility of affecting domestic Saudi 
stability. Thus, Riyadh has moved to pacify public discontent with lavish subsidies. However, for the Saudis, this has impacted the country's ability to withstand periods of low oil prices. And when considering their relations with Iran, and the 'oil production weapon' that they have historically used against Tehran (by overproducing and hurting Iranian revenues), this option will increasingly become more difficult for the Saudis. And it has yet to be determined how other major producers, such as Kuwait or Iraq will be affected.

The third and final factor concerns the future of the unconventional side of the oil industry, particularly the rise of shale oil and natural gas and tight oil. While these technologies have been around for several years, it has only been since 2008 that they have become viable enough to replace output from some conventional suppliers, albeit on a very limited basis. For these unconventional technologies, the key determining factor that would make them competitive with conventional supplies (i.e. OPEC oil) is the cost of recovery. It is important to note, there still exists a wide gap between how much it costs to recover oil from conventional sources vs. unconventional sources. Although individual figures do vary, recovery costs for OPEC crude and other conventional oil producers is roughly less that $1 / 10^{\text {th }}$ that of unconventional production.

Indeed, it was the major spending and growth spurt that started at the turn of the century and ended with the financial crisis that pushed the price of crude oil to unprecedented levels and thus made unconventional production economically feasible. Therefore, due to this recovery cost dynamic, for unconventional supplies to have an impact in the market vis-à-vis conventional producers, the cost of crude must be quite high. Assuming that recovery costs for unconventional supplies do not decrease much, in 
this scenario, the interests of the unconventional producers will become align with traditional OPEC Member States, particularly those with hawkish views on oil. Such an outcome would be a first for the global oil industry, changing alliances and rendering old rivalries relics of the past.

Yet, if the unconventional side of the oil industry becomes more efficient and cheaper, there could, with time, develop a serious risk to OPEC market share and the production rationale of other producers, not unlike what transpired in the $1980 \mathrm{~s}$. And with the uncertainty in regards to the cost, comes also uncertainty vis-à-vis the environment. The environmental effects of large-scale hydraulic fracking and shale oil and natural gas production have yet to be fully tested.

But within these three major trends, the four determinants that have created the context in which OPEC makes its decisions, and thus behaves, will still continue to impact how this Organization engages with others and itself in the international system. And it is within the confluence of these determinants that the longevity and survivability of OPEC is seen. OPEC's capacity to stay together and to continue is precisely because it is not solely an economically based organization and certainly not a cartel. OPEC is an intergovernmental organization where politics and economics, from the domestic to the global, merge and interact for all its Member States. It is a forum of otherwise mediumstrength States, all from the developing world, that do not enjoy any real, objective status or power in any other global institution. It is still an Organization where the overwhelming majority of its Members find, at least some utility, in remaining. And finally, its survivability, is not dependent on ideology or alliances, but one the 
fundamentals of the dominance of hydrocarbons in the current international system - a reality that will not change easily or anytime soon. 


\section{BIBLIOGRAPHY}

Abdul-Rasool, Faik Ali. "Growth and Structural Change of Output in the Economy of Iraq: 1958-1978." OPEC Review 6, no. 1 (1982): 27-40.

Abdullah, B. Peak Oil Paradigm Shift: The Urgent Need for a Sustainable Energy Model: Medianet Limited, 2005.

Abrahamian, E. A History of Modern Iran: Cambridge University Press, 2008.

—. Iran between Two Revolutions: Princeton University Press, 1982.

Abrams, R.A. Reinterpreting Saddam Hussein's Meeting with April Glaspie: Toward a Comic Corrective of an American Victimage Ritual: Indiana University, 1996.

Adelman, M. A. "Is the Oil Shortage Real? Oil Companies as Opec Tax-Collectors." Foreign Policy, no. 9 (1972): 69-107.

Afkhami, G.R. The Life and Times of the Shah: University of California Press, 2009.

Ahrari, M.E. Opec: The Failing Giant: University Press of Kentucky, 1986.

Aïssaoui, Ali, and Algeria: The Political Economy of Oil and Gas: Oxford University Press for the Oxford Institute for Energy Studies, 2001.

Al-Chalabi, F. J. "A Second Oil Crisis? A Producer's Point of View on the Oil Developments of 1979*." OPEC Review 4, no. 4 (1980): 8-19.

Al-Chalabi, F.J. Opec at the Crossroads: Pergamon Press, 1989.

Al-Chalabi, Fadhil. "What Lessons from the Iranian Oil Crisis?" OPEC Review 3, no. 1 (1979): i-iii.

"Al-Hawadith Interviews Crown Prince Amir Fahd." London AL-HAWADITH, 1980, Page C5,Page C6,Page C7,Page C8,Page C9,Page C10,Page C11,Page C12,Page C13,Page C14,Page C15.

Al-Khazraji, A.M. The G.C.C.: Prospects for Gulf Security: University of Limerick, 1994.

Al-Saud, F.S. Iran, Saudi Arabia and the Gulf: Power Politics in Transition 19681971: I.B. Tauris, 2003.

Al-Seghyer, M. Opec: Tested by Fire - Prepared for the Future; a Review of Its Development, History and an Assessment of Its Effectiveness: University of Exeter, 2000. 
Almoayed, A. Opec: The Imperfect Cartel: University of Oxford, 1998.

Amirahmadi, H. Revolution and Economic Transition: The Iranian Experience: State University of New York Press, 1990.

Amirahmadi, Hooshang. "Economic Reconstruction of Iran: Costing the War Damage." Third World Quarterly 12, no. 1 (1990): 26-47.

Arjomand, S.A. The Turban for the Crown: The Islamic Revolution in Iran: Oxford University Press, 1988.

Askari, H. Case Studies of Us Economic Sanctions: Praeger, 2003. 2013. . Conflicts in the Persian Gulf: Origins and Evolution: Palgrave Macmillan,

Banerjee, M. The Nonaligned Movement: Firma KLM Private, 1982.

Baram, A., and B. Rubin. Iraq's Road to War: Palgrave Macmillan, 1996.

Barzel, Y., and C.D. Hall. The Political Economy of the Oil Import Quota: Hoover Institution Press, Stanford University, 1977.

"Beirut Paper Interviews Prince Fahd." Riyadh Domestic Service, 1975, Page C1, Page C2,Page C3, Page C4,Page C5,Page C6,Page C7,Page C8, Page C9.

Bill, James A. "Modernization and Reform from Above: The Case of Iran." The Journal of Politics 32, no. 1 (1970): 19-40.

Bilmes, Linda J. "The Financial Legacy of Iraq and Afghanistan: How Wartime Spending Decisions Will Constrain Future National Security Budgets." Harvard Kennedy School Faculty Research Working Paper Series, no. RWP13-006 (March 2013).

"Boumediene Discusses Foreign, Arab Affairs in Interview." Algiers Domestic Service, 1974, Page T4,Page T5.

Brémond, Vincent, Emmanuel Hache, and Valerie Mignon. "Does Opec Still Exist as a Cartel? An Empirical Investigation." Energy Economics, no. 0 (2011).

Burdett, A. Opec Origins and Strategy 1947-1973 6 Volume Set: Archive Editions Limited, 2004.

Burdett, A.L.P. Opec: Origins \& Strategy, 1947-1973: Archive Editions, 2004.

Business, United States. Congress. Senate. Select Committee on Small. The International Petroleum Cartel (Reprint); Staff Report to the Federal Trade Commission 
Submitted to the Subcommitteeon Monopoly Of ... August 22, 1952. [Reprinted] April 19751975.

Buzan, B., O. Wæver, and J. Wilde. Security: A New Framework for Analysis: Lynne Rienner Pub., 1998.

Buzan, Barry, and Ole Wæver. Regions and Powers: The Structure of International Security: Cambridge University Press, 2003.

Castanias, Richard P. "A Test of the Opec Cartel Hypothesis, 1974-1983: Discussion." The Journal of Finance 40, no. 3 (1985): 1006-08.

Chalabi, F.J. Oil Policies, Oil Myths: Analysis and Memoir of an Opec 'Insider': I. B. Tauris, 2011.

Chalabi, Fadhil J. "Opec: An Obituary." Foreign Policy, no. 109 (1997): 126-40.

Chubin, Shahram. "U.S. Security Interests in the Persian Gulf in the 1980s." Daedalus 109, no. 4 (1980): 31-65.

Cicchetti, Charles J., and Willian J. Gillen. "The Mandatory Oil Import Quota Program: A Consideration of Economic Efficiency and Equity " Natural Resources Journal 13, no. 3 (July 1973): 399-430.

Citino, N.J. From Arab Nationalism to Opec: Eisenhower, King $S a \approx{ }^{a} D$, and the Making of U.S.-Saudi Relations: Indiana University Press, 2002.

- From Arab Nationalism to Opec: Eisenhower, King Saud, and the Making of U.S.-Saudi Relations: Indiana University Press, 2002.

Company, Arabian American Oil. First Arab Petroleum Congress, Cairo, Uar, 16-23 April 1959: Arabian American Oil Company, 1959.

Cooper, A.S. The Oil Kings: How the U.S., Iran, and Saudi Arabia Changed the Balance of Power in the Middle East: Simon \& Schuster, 2011.

- "Showdown at Doha: The Secret Oil Deal That Helped Sink the Shah of Iran." Middle East Journal 62, no. 4 (Autumn 2008): 567-91.

Cordesman, A.H., and A. Hashim. Iran: Dilemmas of Dual Containment: Westview Press, 1997.

Cordesman, A.H., Center for Strategic, and International Studies. Saudi Arabia: National Security in a Troubled Region: Praeger Security International, 2009. 
Countries, Organization of the Petroleum Exporting. Viewpoint 1991: An Opec Series. Edited by Barry Morgan. Vienna, Austria Organization of the Petroleum Exporting Countries., 1992.

\section{—. Viewpoint 1992-1994: A Selection of Speeches}

by Dr Subroto, Secretary General of Opec. Edited by Eduardo Luraschi Graham Patterson, An Opec Series. Vienna, Austria Organization of the Petroleum Exporting Countries., 1994.

- Viewpoint: Opec Series. Vienna, Austria Organization of the Petroleum Exporting Countries., 1989.

Countries, The Organization of Petroleum Exporting. In OPEC Bulletin: Golden Jubilee Edition Vienna, Austria: The Organization of Petroleum Exporting Countries September 2010.

Danielsen, Albert L. "Cartel Rivalry and the World Price of Oil." Southern Economic Journal 42, no. 3 (1976): 407-15.

Dawisha, A. Iraq: A Political History from Independence to Occupation: Princeton University Press, 2009.

Denova, H.M.T., and J.C. Frederick. The History of Venezuela: Greenwood Press, 2005 .

Dockrill, S. Britain's Retreat from East of Suez: The Choice between Europe and the World? 1945-1968: Palgrave Macmillan, 2002.

Donovan, J. The Iran-Iraq War: Antecedents and Conflict Escalation: Taylor \& Francis, 2010.

Doran, Charles F. "Opec Structure and Cohesion: Exploring the Determinants of Cartel Policy." The Journal of Politics 42, no. 1 (1980): 82-101.

Ehrlich, Everett M. "Structural Change in Opec Member Country Production Decisions." OPEC Review 4, no. 4 (1980): 97-121.

Eisenhower, D.D., N.A.R.S.O.F.R. General Services Administration, United States Government Printing Office, and Office of the Federal Register. Public Papers of the Presidents of the United States, Dwight D. Eisenhower, 1959: Containing the Public Messages, Speeches, and Statements of the President, January 1 to December 31, 1959: Office of the Federal Register, 1999.

El-Mokadem, A.M. Opec and the World Oil Market, 1973-1983: Eastlords Pub., 1983. 
Evans, John. Opec, Its Member States and the World Energy Market. Harlow, Essex, U.K. : Longman, 1986.

Farouk-Sluglett, M., and P. Sluglett. Iraq since 1958: From Revolution to Dictatorship: I. B. Tauris, 2001.

Fasano, U., and Z. Iqbal. Gcc Countries: From Oil Dependence to Diversification: International Monetary Fund, 2003.

Fattouh, Bassam. "An Anatomy of the Crude Oil Pricing System." The Oxford Institute for Energy Studies, January 2011.

- "The Origins and Evolution of the Current International Oil Pricing System: A Critical Assessment " In Oil in the 21st Century: Issues, Challenges and Opportunities, edited by Robert Mabro and Published by the Oxford University Press for the Organization of the Petroleum Exporting Countries, 2006.

Fawcett, L.L.E. Iran and the Cold War: The Azerbaijan Crisis of 1946: Cambridge University Press, 1992.

Fitzpatrick, Sheila. The Russian Revolution. New York Oxford University Press, 1982. 1994.

Fraser, Niall M., Keith W. Hipel, John Jaworsky, and Ralph Zuljan. "A Conflict Analysis of the Armenian-Azerbaijani Dispute." The Journal of Conflict Resolution 34, no. 4 (1990): 652-77.

Fromkin, D. A Peace to End All Peace: The Fall of the Ottoman Empire and the Creation of the Modern Middle East: H. Holt, 2001.

Gately, Dermot, M. A. Adelman, and James M. Griffin. "Lessons from the 1986 Oil Price Collapse." Brookings Papers on Economic Activity 1986, no. 2 (1986): 237-84.

Gault, John, Charles Spierer, Jean-Luc Bertholet, and Bahman Karbassioun. "How Does Opec Allocate Quotas?" Journal of Energy Finance and Development 4 (1999): $137-48$.

Gause, F.G. The International Relations of the Persian Gulf: Cambridge University Press, 2009.

. Oil Monarchies: Domestic and Security Challenges in the Arab Gulf States: Council on Foreign Relations Press, 1994.

Ghadar, Fariborz. The Evolution of Opec Strategy. Lexington, MA: Lexington Books, 1977. 
Gleason, Gregory. "The Federal Formula and the Collapse of the Ussr." Publius 22, no. 3 (1992): 141-63.

Golan, G. Soviet Policies in the Middle East: From World War Two to Gorbachev: Cambridge University Press, 1990.

Goldman, M.I. Petrostate: Putin, Power, and the New Russia: Oxford University Press, USA, 2010.

Gott, R. Hugo Chavez and the Bolivarian Revolution: Verso, 2011.

- In the Shadow of the Liberator: Hugo Chavez and the Transformation of Venezuela: Verso, 2000.

Griffin, James $\neg \nmid \mathrm{M}$, and Weiwen Xiong. "The Incentive to Cheat: An Empirical Analysis of Opec." Journal of Law and Economics 40, no. 2 (1997): 289-316.

Guidi, Marco G. D., Alexander Russell, and Heather Tarbert. "The Effect of Opec Policy Decisions on Oil and Stock Prices." OPEC Review 30, no. 1 (2006): 1-18.

Hagger, Nicholas The Libyan Revolution: Its Origins and Legacy : A Memoir and Assessment: O Books, 2009.

Halliday, F. The Middle East in International Relations: Power, Politics and Ideology: Cambridge University Press, 2005.

Hansen, P.V., and L. Lindholt. The Market Power of Opec 1973 - 2001: Statistics Norway, 2004.

Hanson, Philip. "Economic Constraints on Soviet Policies in the 1980s." International Affairs (Royal Institute of International Affairs 1944-) 57, no. 1 (1980): 2142.

Herring, G.C. From Colony to Superpower: U.S. Foreign Relations since 1776: Oxford University Press 2009.

Heshmatzadeh, Mohammad Baqer. "50 Years of Opec and Politics." Rahbord 20 (60), no. Fall (2011): 113-40.

Hiro, D. The Longest War: The Iran-Iraq Military Conflict: Routledge, 1989.

Historian, United States Department of State: Office of the. Foreign Relations of the United States, 1964-1968. Edited by Susan K. Holly and David S. Patterson. Vol. Volume XXXIV, Energy Diplomacy and Global Issues Washington: U.S. G.P.O., 1999. 
- Foreign Relations of the United States, 1969-1976 Edited by Monica Belmonte and Edward C. Keefer. Vol. Volume E-4, Documents on Iran and Iraq, 19691972. Washington: U.S. G.P.O., 2006.

- Foreign Relations of the United States, 1969-1976. . Edited by Nina Howland, Craig Daigle and Edward C. Keefer. Vol. Volume XXV, Arab-Israeli Crisis

and War, 1973. Washington: U.S. G.P.O., 2011.

- Foreign Relations of the United States, 1969-1976. . Edited by Linda Qaimmaqami \& Edward C. Keefer. Vol. Volume XXXVI, Energy Crisis Washington: U.S. G.P.O., 2011.

- Foreign Relations of the United States, 1973-1976. Edited by Kathleen B. Rasmussen and Edward C. Keefer. Vol. Volume XXXI, Foreign Economic Policy. Washington: U.S. G.P.O., 2009.

Homer-Dixon, T. Carbon Shift: How Peak Oil and the Climate Crisis Will Change Canada (and Our Lives): Random House of Canada, 2011.

Howard, R. The Oil Hunters: Exploration and Espionage in the Middle East: Bloomsbury, 2008.

Hurewitz, J. C. "The Persian Gulf: British Withdrawal and Western Security." Annals of the American Academy of Political and Social Science 401, no. ArticleType: research-article / Issue Title: America and the Middle East / Full publication date: May, 1972 / Copyright $\neg$ C 1972 American Academy of Political and Social Science (1972): 106-15.

Husayn, A. Iraq: The Eternal Fire: 1972 Iraqi Oil Nationalization in Perspective: Third World Centre for Research and Publishing, 1981.

Ibrahim, Y. The Future of Opec: Middle East Institute, 1984.

Iwayemi, Akin, and Babajide Fowowe. "Oil and the Macroeconomy: Empirical Evidence from Oil-Exporting African Countries." OPEC Energy Review 35, no. 3 (2011): 227-69.

Iyamah, G.E. Opec Cartel: An Analysis of Its Strength and How to Weaken Its Hold on the U.S. Economy: Morgan State University, 1979.

Jacobsen, Eric. "A Coincidence of Interests: Kennedy, U.S. Assistance, and the 1963 Iraqi Ba'th Regime." Diplomatic History (2013).

Jaidah, Ali M. "Pricing of Oil: Role of the Controlling Power." OPEC Review 1, no. 5 (1977): 3-16. 
Jan, Kuwait., Saudi Arabia. Jan, and Libya. Jan. Agreement of the Organization of Arab Petroleum Exporting Countries 1968.

Johany, A.D. The Myth of the Opec Cartel: The Role of Saudi Arabia: University of Petroleum and Minerals, 1980.

John, R.B.S. Libya: From Colony to Independence: Oneworld, 2008.

Kakar, H. Afghanistan: The Soviet Invasion and the Afghan Response, 1979-1982: University of California Press, 1997.

Kamrava, M. The Modern Middle East: A Political History since the First World War: University of California Press, 2011.

Karsh, E. The Iran-Iraq War: Rosen Pub., 2009.

Kennedy, Michael. "An Economic Model of the World Oil Market." The Bell Journal of Economics and Management Science 5, no. 2 (1974): 540-77.

Keohane, R.O. After Hegemony: Cooperation and Discord in the World Political Economy: Princeton University Press, 1984, 2005.

Khadduri, M., and E. Ghareeb. War in the Gulf, 1990-91: The Iraq-Kuwait Conflict and Its Implications: Oxford University Press, 2001.

Khan, Alim. The Nonaligned Movement: Achievements, Problems, Prospects: Novosti Press Agency Publishing House, 1985.

King, R.P.H. U.N. And the Iran-Iraq War: Diane Publishing Company, 1987.

Kinzer, S. All the Shah's Men: An American Coup and the Roots of Middle East Terror: Wiley, 2011.

Klare, M.T. Resource Wars: The New Landscape of Global Conflict: Henry Holt and Company, 2002.

Klein, Donald W. "Japan 1979: The Second Oil Crisis." Asian Survey 20, no. 1 (1980): 42-52.

Kozloff, N. Hugo Chavez: Oil, Politics, and the Challenge to the U.S: Palgrave Macmillan, 2007. 23-33.

Krauthammer, Charles. "The Unipolar Moment." Foreign Affairs 70, no. 1 (1990):

Kurzman, C. The Unthinkable Revolution in Iran: Harvard University Press, 2004. 
Lake, D.A., and P.M. Morgan. Regional Orders: Building Security in a New World: Pennsylvania State University Press, 1997.

Lanning, Steven G. "Costs of Maintaining a Cartel." The Journal of Industrial Economics 36, no. 2 (1987): 157-74.

LeClair, M.S. International Commodity Markets and the Role of Cartels: M.E. Sharpe, 2000.

Leffler, M.P. For the Soul of Mankind: The United States, the Soviet Union, and the Cold War: Farrar, Straus and Giroux, 2007.

Levy, Walter J. "Oil and the Decline of the West." Foreign Affairs 58, no. 5 (1980): 999-1015.

"Libya, Syria Will Not Comply." Tripoli Domestic Service FBIS-MEA-74-056, DAILY REPORT. MIDDLE EAST \&amp; AFRICA (1974): Page A1.

Linde, C. The State and the International Oil Market: Competition and the Changing Ownership of Crude Oil Assets: Kluwer Academic, 2000.

Linquiti, P.D. Indonesia and Opec: The Economic Costs of Cartel Membership: East Asian Program, The Wilson Center, 1982.

Little, D. American Orientalism: The United States and the Middle East since 1945: University of North Carolina Press, 2008.

Loderer, Claudio. "A Test of the Opec Cartel Hypothesis: 1974-1983." The Journal of Finance 40, no. 3 (1985): 991-1006.

Luft, G., and A. Korin. Turning Oil into Salt: Energy Independence through Fuel Choice: Booksurge.com, 2009.

Mabro, Robert. "The International Oil Price Regime: Origins, Rationale and Assessment." The Journal of Energy Literature XI, no. 1 (June 2005): 3-20.

—_. "On Oil Price Concepts." Oxford Institute for Energy Studies, 1984.

—_. "On Oil Price Concepts." WPM 3: Oxford Institute for Energy Studies, 1984.

Mackey, S. The Reckoning: Iraq and the Legacy of Saddam Hussein: Norton, 2003.

Malcolm, Neil. "The 'Common European Home' and Soviet European Policy." International Affairs (Royal Institute of International Affairs 1944-) 65, no. 4 (1989): 659-76. 
Malnes, Raino. "Opec and the Problem of Collective Action." Journal of Peace Research 20, no. 4 (1983): 343-55.

Marcel, V., and J.V. Mitchell. Oil Titans: National Oil Companies in the Middle East: Chatham House, 2006.

Marien, M. Future Survey Annual 1986: A Guide to the Recent Literature of Trends, Forecasts, and Policy Proposals: Transaction Publishers, 1987.

Maugeri, L. The Age of Oil: The Mythology, History, and Future of the World's Most Controversial Resource: Abc-Clio Incorporated, 2006.

Maynard, C. Out of the Shadow: George H.W. Bush and the End of the Cold War: Texas A\&M University Press, 2008.

Mazraati, M., and S. M. Tayyebi Jazayeri. "Oil Price Movements and Production Agreements." OPEC Review 28, no. 3 (2004): 207-26.

Mead, Walter J., and Philip E. Sorensen. "A National Defense Petroleum Reserve Alternative to Oil Import Quotas." Land Economics 47, no. 3 (1971): 211-24.

Mearsheimer, John J., and Stephen M. Walt. "An Unnecessary War." Foreign Policy, no. 134 (2003): 50-59.

Mesbahi, Mohiaddin. "The USSR and the Iran-Iraq: From Brezhnev to Gorbachev." In The Iran-Iraq War: The Politics of Aggression, edited by F. Rajaee, 69-103: University Press of Florida, 1993.

Mexico, Government of. Mexico's Oil: A Compilation of Official Documents in the Conflict of Economic Order in the Petroleum Industry, with an Introduction Summarizing Its Causes and Consequences: Government of Mexico via The University of Michigan 1940 (digitized August 2006).

Milani, A. The Shah: Palgrave Macmillan, 2011.

Milani, M.M. The Making of Iran's Islamic Revolution: From Monarchy to Islamic Republic: Westview Press, 1994.

Milani, Mohsen. The Making of Iran's Islamic Revolution: From Monarchy to Islamic Republic: Westview Press, 1994.

"Minister Says Saudi Arabia Almost Left Opec." Paris AFP, 1975, Page R2.

Moran, Theodore H. "Modeling Opec Behavior: Economic and Political Alternatives." International Organization 35, no. 2 (1981): 241-72. 
. Oil Prices and the Future of Opec: The Political Economy of Tension and Stability in the Organization of Petroleum Exporting Countries. Washington, DC Resources for the Future, 1978.

Naylor, Phillip C. . France and Algeria: A History of Decolonization and Transformation: University Press of Florida, 2000.

O'Connor, R. The Oil Barons: Men of Greed and Grandeur: Little, Brown, 1971.

Ogütçü, Mehmet. "Eurasian Energy Prospects and Politics: Need for a Fresh Perspective." Cahiers d'Etudes sur la Méditerranée Orientale et le monde Turco-Iranien 19 (January 1995): http://cemoti.revues.org/1705.

"Oil Minister Interview." Tehran Domestic Service, November 14 1979, R6-R12.

OPEC. Opec Official Resolutions and Press Releases 1960-1990: The Secretariat, Organization of the Petroleum Exporting Countries, 1990.

- Opec Official Resolutions and Press Releases 1990-1997: The Secretariat, Organization of the Petroleum Exporting Countries, 1998.

Organization of Petroleum Exporting Countries. Annual Report: Organization of the Petroleum Exporting Countries, 2004.

Organization of Petroleum Exporting Countries. Annual Report: Organization of the Petroleum Exporting Countries, 2005.

Organization of Petroleum Exporting Countries. Annual Report: Organization of the Petroleum Exporting Countries, 2006.

Oren, M.B. Six Days of War: June 1967 and the Making of the Modern Middle East: RosettaBooks, 2004.

Ortiz, R.G., and Organization of Petroleum Exporting Countries. Viewpoint: Selection of Speeches: OPEC, 1981.

Parra, F.R. Opec and the Oil Industry in the Middle East: Organization of Petroleum Exporting Countries, 1962.

Parra, Francisco Oil Politics: A Modern History of Petroleum: I.B. Tauris, 2004.

Penrose, E.T., and P.R. Odell. The Large International Firm in Developing Countries: The International Petroleum Industry: Greenwood Press, 1976.

Pickering, J. Britain's Withdrawal from East of Suez: The Politics of Retrenchment: Macmillan Press, 1998. 
"Pierre Salinger Interviews Perez on Energy Conference." Paris L'EXPRESS, 1975, Page L1, Page L2,Page L3.

Pitt, E.R., and C.N. Leung. Opec, Oil Prices and Lng: Nova Science Pub Inc, 2009.

Plunkett, J.W. Plunkett's Energy Industry Almanac 2008: Plunkett Research, Limited, 2007.

"Premier Says Opec Front Will Not Be Broken." Milan CORRIERE DELLA SERA, 1974, Page K1,Page K2.

Rabinovich, A. The Yom Kippur War: The Epic Encounter That Transformed the Middle East: Knopf Doubleday Publishing Group, 2007.

Rajaee, F. The Iran-Iraq War: The Politics of Aggression: University Press of Florida, 1993.

Ramazani, Rouhollah K. "Iran's 'White Revolution': A Study in Political Development." International Journal of Middle East Studies 5, no. 2 (1974): 124-39.

Resources, United States. Congress. Senate. Special Committee Investigating Petroleum. American Petroleum Interests in Foreign Countries: Hearings before a Special Committee Investigating Petroleum Resources, United States Senate, SeventyNinth Congress, First Session, Pursuant to S. Res. 36 (Extending S. Res. 253, 78th Congress) a Resolution Providing for an Investigation with Respect to Petroleum Resources in Relation to the National Welfare. June 27 and 28, 1945: U.S. Government Printing Office via ARNO Press, A New York Times Company 1946, 1976.

Roberts, P. The End of Oil: On the Edge of a Perilous New World: Houghton Mifflin, 2005.

Rositzke, Harry August. The Cia's Secret Operations: Espionage, Counterespionage, and Covert Action: Westview Press, 1977.

Rouhani, F. A History of O.P.E.C: Praeger, 1971.

Sadli, H. E. Mohammad. "A Message from the President." OPEC Review 1, no. 1 (1976): 1-2.

Sampson, A. The Seven Sisters: The Great Oil Companies and the World They Shaped. New York: The Viking Press, 1975.

Seymour, Ian. Opec: Instrument of Change. London, UK: Macmillan, 1980.

Seawright, Jason, Party-System Collapse: The Roots of Crisis in Peru and Venezuela: Stanford University Press, 2012. 
"Shah Discusses Oil-Price Issue in Bbc Interview." London Domestic Service, 1974, Page R1,Page R2,Page R3.

Shaked, H., and I. Rabinovich. The Middle East and the United States: Perceptions and Policies: Transaction Books, 1980.

Shihata, I.F.I. The Opec Fund for International Development: The Formative Years: Taylor \& Francis, 2010.

Shimokawa, K. The Japanese Automobile Industry: A Business History: Bloomsbury, 1994.

Shojai, S., and B.S. Katz. The Oil Market in the 1980's: A Decade of Decline: Praeger, 1992.

Skeet, Ian. Opec: Twenty-Five Years of Prices and Politics: Cambridge University Press, 1991. 1991.

. Opec: Twenty-Fve Years of Prices and Politics: Cambridge University Press,

Smith, James L. "Inscrutable Opec: Behavioral Tests of the Cartel Hypothesis." SSRN eLibrary (2002).

Smolansky, Oles M., and B.M. Smolansky. The Ussr and Iraq: The Soviet Quest for Influence: Duke University Press, 1991.

Sponeck, H.C. A Different Kind of War: The Un Sanctions Regime in Iraq: Berghahn Books, 2006.

Stagliano, V. A Policy of Discontent: The Making of a National Energy Strategy: Pennwell Corporation, 2001.

Stevens, Harley C. "Some Reflections on the First Arab Petroleum Congress." Middle East Journal 13, no. 3 (1959): 273-80.

Stiglitz, J.E. Globalization and Its Discontents: W. W. Norton, 2003.

Swearingen, Will D. "Geopolitical Origins of the Iran-Iraq War." Geographical Review 78, no. 4 (1988): 405-16.

Tarock, Adam. The Superpowers' Involvement in the Iran-Iraq War: Nova Science Publishers, 1998.

"Text of 14 December Azhari Interview." Tehran Domestic Service, 1978, Page R2,Page R3,Page R4,Page R5,Page R6,Page R7, Page R8. 
Tordo, Silvana, Brandon S. Tracy, and Noora Arfaa Arfaa. National Oil Companies and Value Creation. III vols. Vol. I. Washington, D.C. : World Bank Publications, 2011.

Tugwell, F. The Energy Crisis and the American Political Economy: Politics and Markets in the Management of Natural Resources: Stanford University Press, 1988.

—. The Politics of Oil in Venezuela: Stanford University Press, 1975.

van der Pijl, K. Global Rivalries from the Cold War to Iraq: Pluto Press, 2006.

Vernon, R. The Oil Crisis: Norton, 1976.

Victor, D.G., D.R. Hults, and M.C. Thurber. Oil and Governance: State-Owned Enterprises and the World Energy Supply: Cambridge University Press, 2011.

Vietor, R.H.K. Energy Policy in America since 1945: A Study of BusinessGovernment Relations: Cambridge University Press, 1987.

Wallace, William. "British Foreign Policy after the Cold War." International Affairs (Royal Institute of International Affairs 1944-) 68, no. 3 (1992): 423-42.

Walsh, L.E. Firewall: The Iran-Contra Conspiracy and Cover-Up: Norton, 1998.

Westad, Odd A. The Global Cold War: Third World Interventions and the Making of Our Times: Cambridge University Press, 2005.

White, N.D. The Law of International Organisations: Juris Pub., 2005.

Wilkins, Mira. "Multinational Oil Companies in South America in the 1920s: Argentina, Bolivia, Brazil, Chile, Colombia, Ecuador, and Peru." The Business History Review 48, no. 3 (1974): 414-46.

—. "The Oil Companies in Perspective." Daedalus 104, no. 4 (1975): 159-78.

Wonnacott, P., and R.J. Wonnacott. Economics: Wiley, 1990.

Wright, S.M. The United States and Persian Gulf Security: The Foundations of the War on Terror: Ithaca Press, 2007.

Yeganeh, Mohammed. "Opec Special Fund: An Illustration of Solidarity with the Third World." OPEC Review 1, no. 4 (1977): 3-9.

Yergin, Daniel. The Prize: The Epic Quest for Oil, Money, \& Power. New York, NY: Simon \& Schuster, 1991. 
- The Quest: Energy, Security, and the Remaking of the Modern World: Penguin Group US, 2011.

Yorke, Valerie. "Oil, the Middle East and Japan's Search for Security." International Affairs (Royal Institute of International Affairs 1944-) 57, no. 3 (1981): 428-48.

Zabih, Sepehr. "Iran's Policy toward the Persian Gulf." International Journal of Middle East Studies 7, no. 3 (1976): 345-58. 
VITA

REZA SANATI

Born, Los Angeles, California

2001

B.A., Psychology,

Loyola Marymount University

Los Angeles, California

2002-2006

Risk Management Analyst, ISO

Los Angeles, California

2007

Freelance Journalist

Los Angeles, California

2008-2011

Teaching Assistant

Florida International University

Miami, Florida

2008-2014

Graduate Research Fellow

Middle East Studies Center

Miami, Florida

2011

M.A., International Relations

Florida International University

Miami, Florida

2011-2014

Adjunct Professor

Florida International University

Miami, Florida

2012-2014

Doctoral Candidate

Florida International University

Miami, Florida

\section{PUBLICATIONS}

Reza Sanati, "Transitioning Afghanistan in the Post-Withdrawal Era: Setting the stage for a stable political order", Alternatives: Turkish Journal of International Relations, Summer 2011, 93-114.

Reza Sanati \& Mohammad Homayounvash, “Understanding the Logic of Iran's Nuclear Program”, Muftah, April, 2012, http://muftah.org/understanding-the-logic-of-iransnuclear-program/ 
Reza Sanati, "Pipeline Politics: The Geopolitical Struggle over an Iran-Pakistan-India Energy Deal," Cairo Review of Global Affairs, June 2013, 101-111.

Reza Sanati, "Beyond the domestic picture: How international politics shapes IranUS relations", Global Change, Peace, \& Security, June 2014.

\section{PRESENTATIONS}

Cal State Fresno Middle East Society: October 2008, Fresno, CA.

"Taxonomy of Threat: Iran-US mutual threat perceptions"

International Studies Association-Northeast: October 2009, Baltimore, MD

"The Proliferation of Post-Modern Deterrence: Asymmetry, the State, and the System"

International Studies Association-Midwest: November 2009, St. Louis, MO

“The Eurasian Security Complex: Energy's Role in Transcending the Traditional Security Complex

International Studies Association-National: March 2010, New Orleans, LA "Eurasia's Energy Dynamics: The Security Complex Approach to Post-Soviet Eurasia"

International Studies Association-West: September 24-25, 2010, Los Angeles, CA "Iranian Economic Duality: Tehran's Foreign Relations in the Context of Ideology, Rentierism, and Pragmatism

International Studies Association-West: September 23-24, 2011, Los Angeles, CA "Transitioning Afghanistan: A discussion on Post-Withdrawal US Policy in Afghanistan" "Beyond the domestic picture: How international politics shapes the Iranian-American interaction"

Middle East Studies Association: November 17-20, 2012, Denver, CO

"The Intersection of Iran's Energy Export Strategy with Its Nuclear Industry"

Middle East Studies Association: October 10-13, 2012, New Orleans, LA

"The Much Delayed Peace Pipeline: Iran-Pakistan-India Natural Gas"

International Studies Association-West: March 25-29, 2014, Toronto, Canada

"The International Political Economy of Iranian Energy Policy"

FELLOWSHIPS AND AWARDS

2008 - Honorarium: Conference at California State University Fresno

2012 - Florida International University, Dissertation Evidence Acquisition Award 